Historic, Archive Document

Do not assume content reflects current scientific knowledge, policies, or practices. 



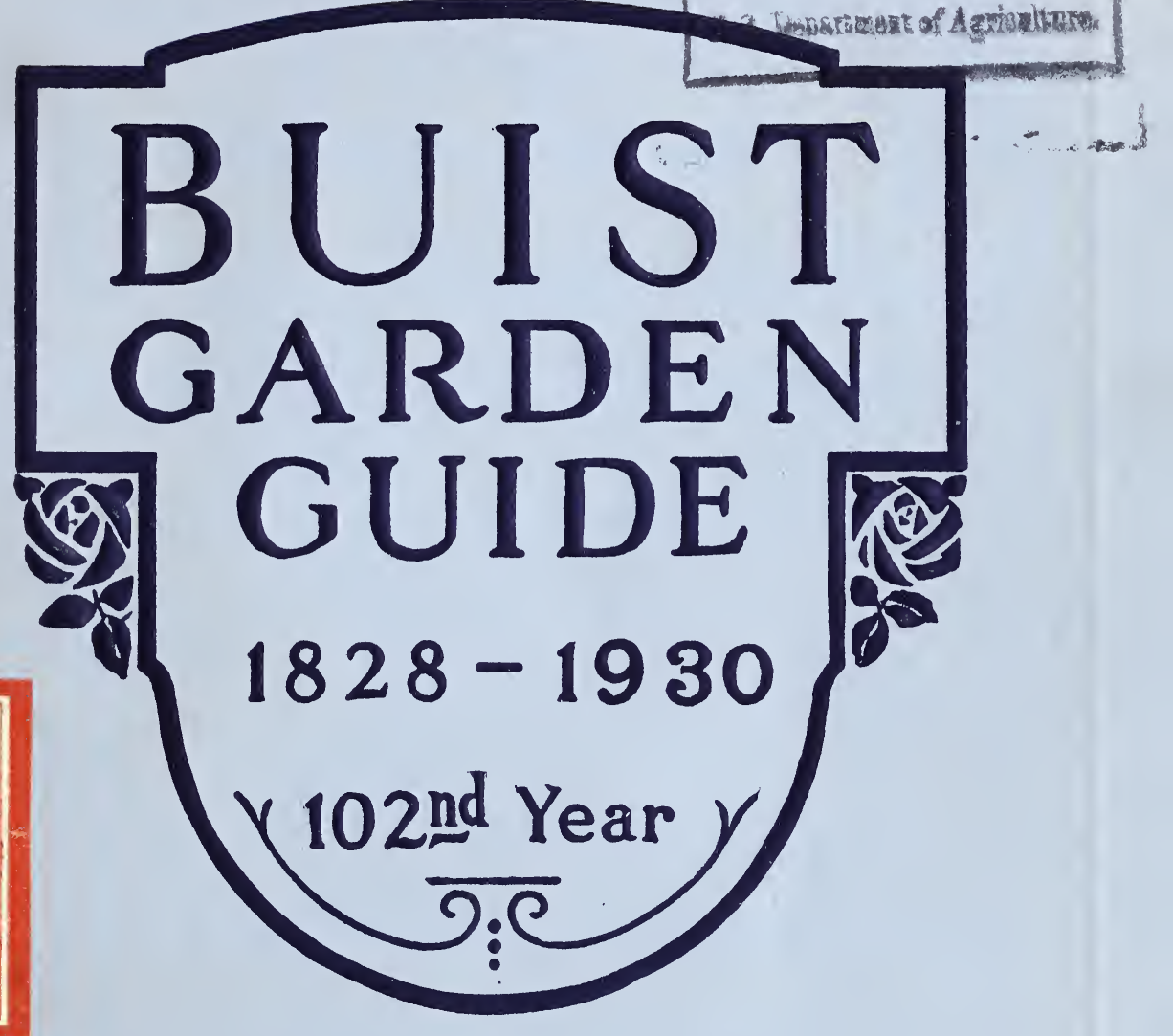

ROBERT BUIST COMPANY

Seed Growers

Philadelphia, PA. 


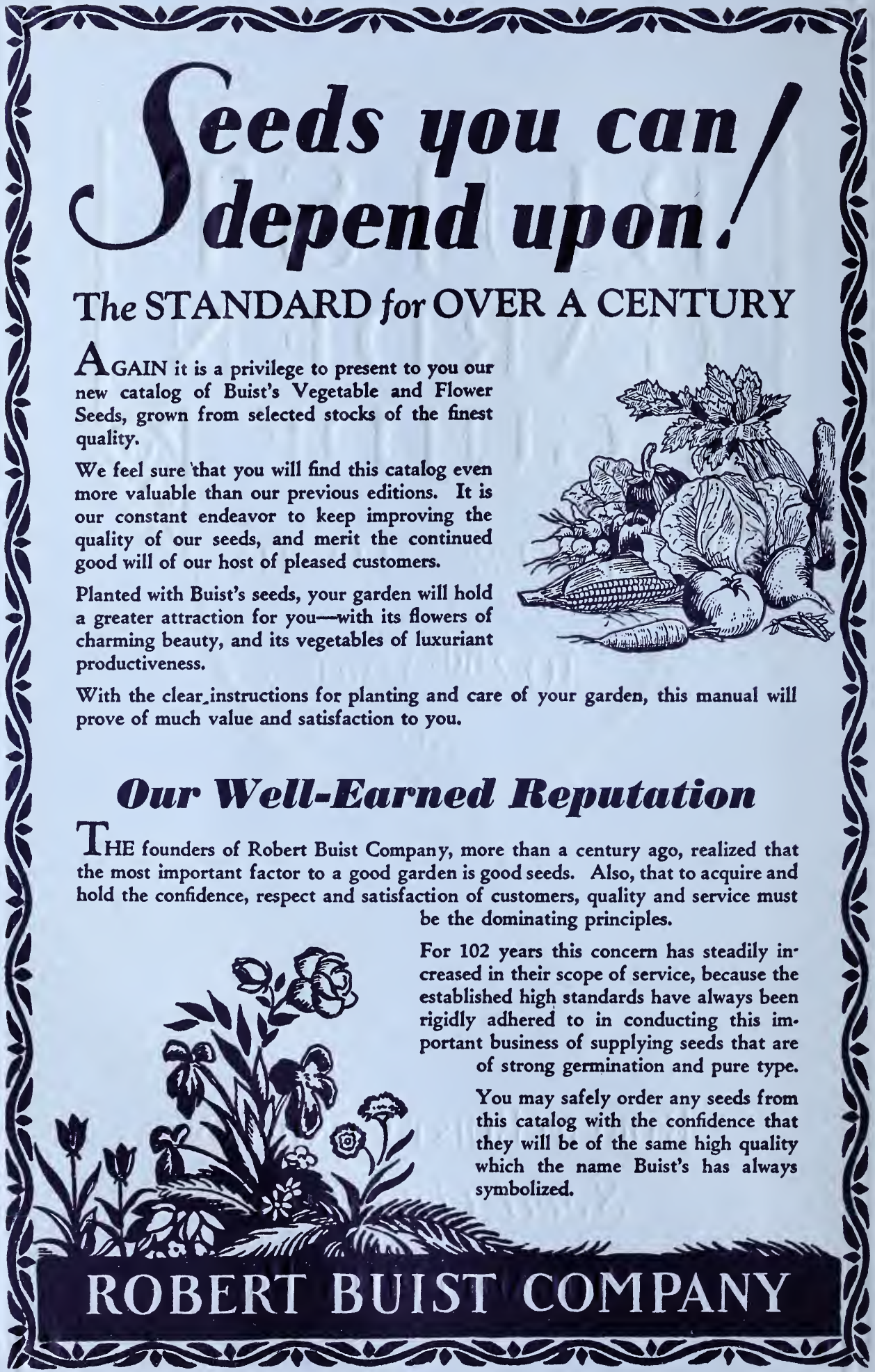




\section{BUIST'S SPECIAL}

\section{Free Offer of Flower Seeds}

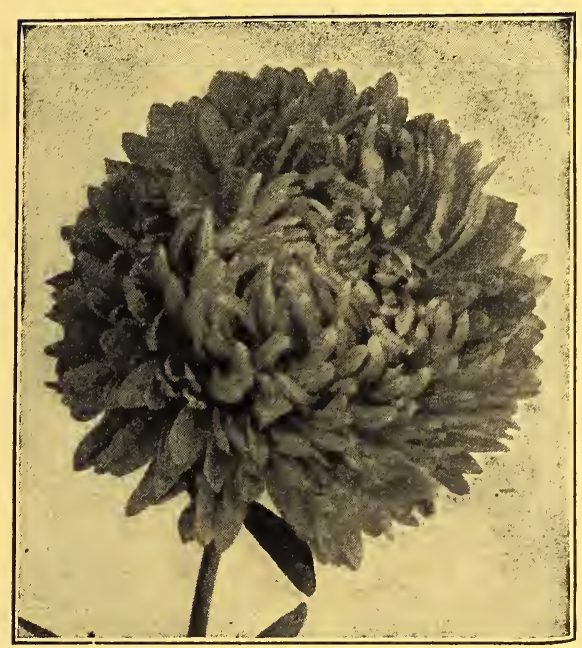

Buist's Giant Asters

1 Pkt. Buist's Giant Asters. A mag, nificent mixture, producing flowers gorgeous in colors and perfect in form. They are wonderfully prolific and bloom from August until frost. Valuable for cutting.

1 Pkt. Buist's Giant Zinnia. Flowers of gigantic size, densely double, with a wonderful range of brilliant colors. To attain maximum size, allow 18 inches each way between plants, as they are robust growers.

The above varieties are unequalled in quality and cannot fail to give satisfaction to the most critical flower lovers.

\section{This Offer Includes Orders Received to June First}

\section{ROBERT BUIST CO.}

\section{BEAUTIFY YOUR HOME}

Flowers Beautify and Make Attractive the Home as Nothing Else Can Do

\section{OUR FREE OFFER}

We will include during the Spring season of 1930, with every order of 50c and over from this Catalogue, one packet each of the following easily grown Summer blooming Flower Seeds (Absolutely Free), all of easy culture, which will flower profusely from early Spring until late in the Fall.

1 Pkt. California Poppy. The state flower of California. A bright freeflowering plant of low-spreading growth with gaily colored flowers of a satiny finish.

1 Pkt. Annual Chrysanthemum. (Painted Daisy.) Exquisitely colored daisy-like flowers. They bloom profusely from early Summer until frost, unsurpassed as a cut flower.

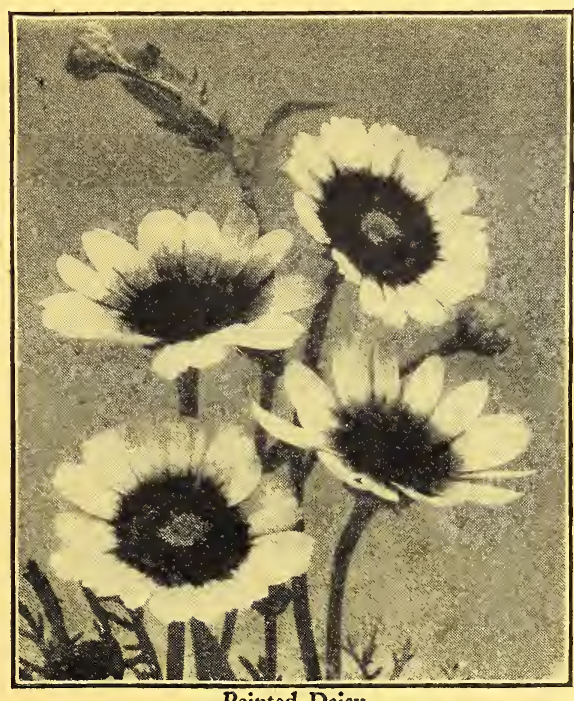

Painted Daisy 


\section{BUIST'S Novelties and Specialties}

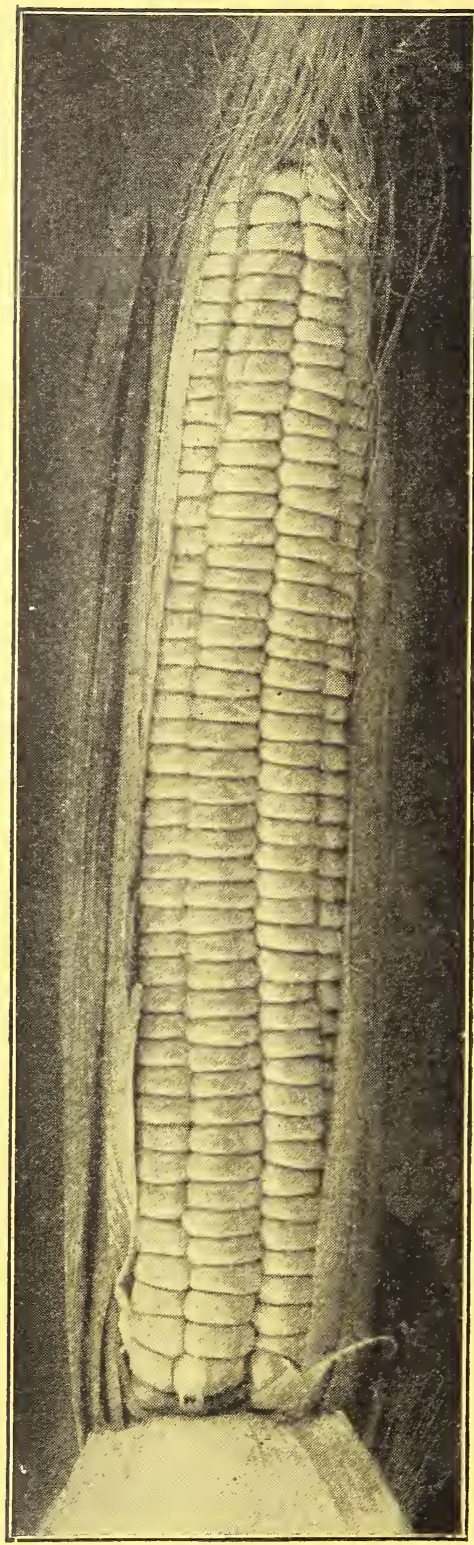

Buist's Golden Dawn Corn

\section{Buist's Ideal Dark Red Beet}

In this we offer our customers an ideal beet for either the market garden or the home garden. It is also the best for canning. The color is dark blood-red with deeper rings, which disappear when cooked, turning the entire beet into the rich dark blood color so much desired. The roots are globular, smooth, clean, always tender and of unequalled flavor. It is the best variety to sow in the Spring to follow the early sorts. Pkt., 10c; 1/2 oz., 15c; oz., 25c; 1/4 lb., 75c; lb., \$2.50.

\section{Early Green Calabrese Broccoli}

A variety largely grown by Italian market gardeners. It is easy of culture and rapid growing, producing large bluish green heads at the center of the plant in about ninety days. When this central head is removed, numerous branches and lateral heads are formed that are as desirable as the first head. Both stems and heads are tender, delicious and savory and bear liberally until frost. (See page 25.) Pkt., 15c; 1/2 oz., 55c; oz., $\$ 1.00$; 1/4 lb., \$3.25; lb., \$12.00.

\section{Coreless Chantenay Carrot}

The outstanding features of this strain are the ex. cellent color of both the exterior and interior, the smoothness and uniformity of the roots. The flesh is fine-grained, absolutely free from core and stringiness or coarseness. The flesh is of the finest flavor. Pkt., $10 \mathrm{c}$; oz., 20c; 1\%4 lb., 60c; lb., \$2.00.

\section{Buist's "Veribest" Snowball Cauliflower}

An early maturing variety that is strongly resistant to disease and adverse weather conditions. The crop practically heads all at one time. Heads are deep, pure white, hard and solid. It is suitable not only for an early crop, but is superior for late planting. Pkt., 40c; $1 / 8$ oz., 80c; 1/4 oz., \$1.50; 1/2 oz., \$2.65; oz., \$5.00.

\section{New Golden Phenomenal Celery}

An improvement on the Golden Plume with all the good qualities of that variety, but in addition is taller and has longer edible stalks. The plants are heavy, compact and full-hearted. The stems are broad, thick, brittle and of excellent flavor. Pkt., 25c; 14 oz., \$1.15; $1 / 2$ oz., \$2.50; oz., \$4.50; $1 / 4$ lb., $\$ 15.00$.

\section{Buist's Golden Dawn Sugar Corn}

The earliest golden sweet corn. The ears average $61 / 2$ inches with twelve rows of bright golden grains. This variety is especially sweet, delicious and tender. It is more dwarf than Golden Bantam and seven to ten days earlier. Pkt., 10c; 1/2 lb., 25c; 1 lb., 40c; 2 lbs., 70c; 10 lbs., $\$ 3.00$.

\section{Sugar Rock Muskmelon}

Sweet as sugar and solid as a rock. A new type melon of delicious flavor and sweetness. A wonderful shipper because of its heavy netting and tough rind. Flesh deep orange with a flavor distinct from other sorts. (See page 53.) Pkt., 10c; b/2 oz., 20c; oz., 30c; $1 / 4$ lb., 90c; lb., $\$ 3.00$.

\section{California Wonder Pepper}

An exceedingly large pepper of real merit. The flesh is exceptionally thick, heavier and firmer than any other sort. In addition to the thickness of the flesh, it is sweet, crisp and tender, and entirely free from pungency. Pkt., 15c; 1/2 oz., 35c; oz., 65c; $1 / 4$ lb., \$2.25; lb., $\$ 8.00$. 


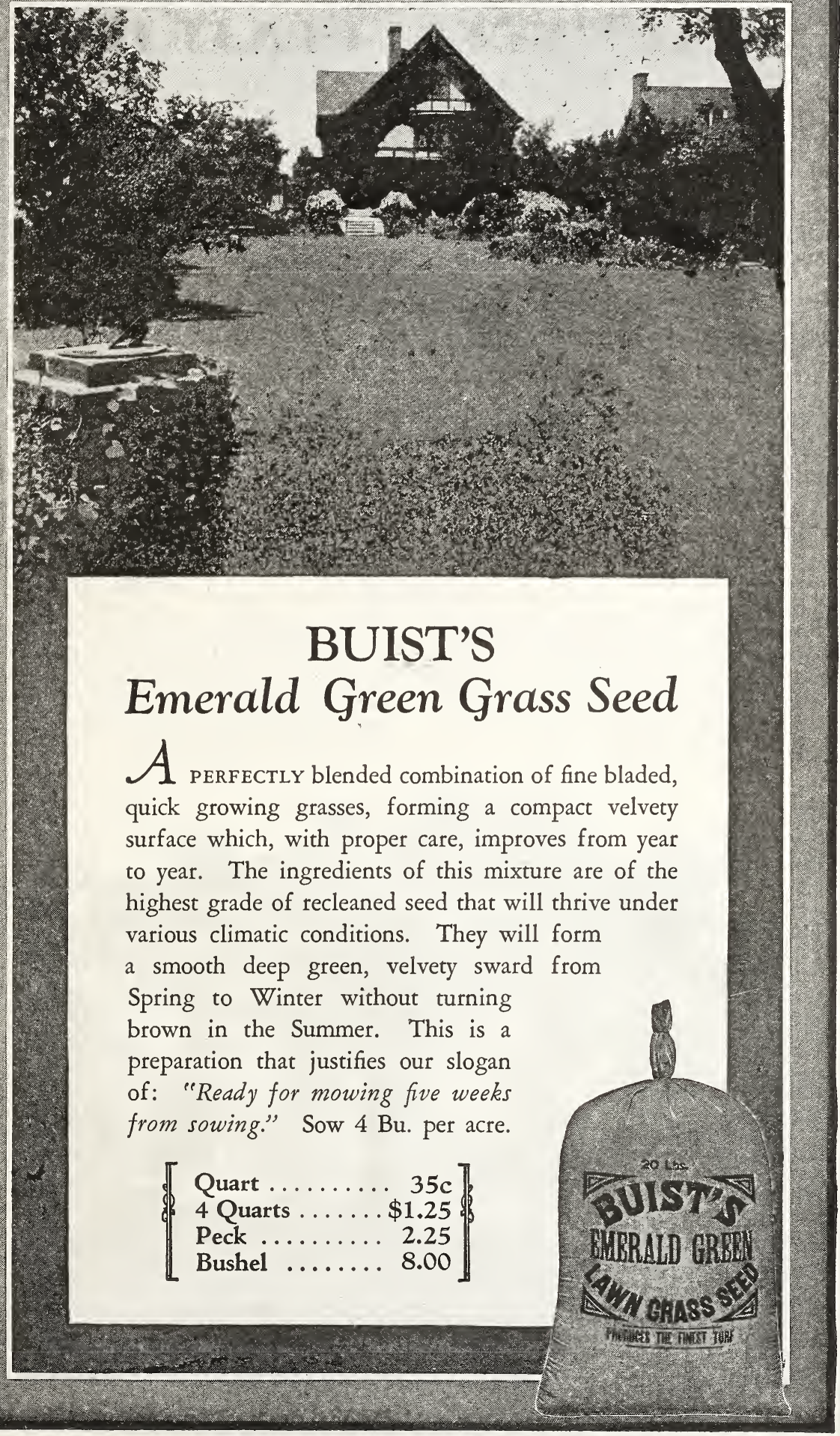




\section{6

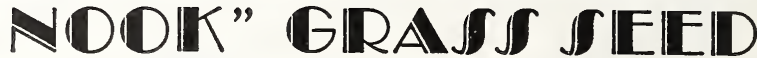

TN THIS mixture we have combined fine, dwarf growing evergreen varieties of grasses

1 which do well in sheltered or shaded spots when difficulty is experienced in getting grass to grow. Our Shady Nook Mixture will bring greenness to the bare spots and restore the beauty to your lawn. Sow four bushels per acre.

Qt. 35c, 4 Qts. \$1.25, Pk. \$2.25, Bu. \$8.00.

\section{B U I S T'S} Terrace

\section{Grass Seed}

A MIXTURE of

A grasses that root de e ply and spread, making a heavy mat of sod. This $\mathrm{mixture}$ is the best for sowing on terraces, embankments and hillsides, as it prevents heavy rains from washing out

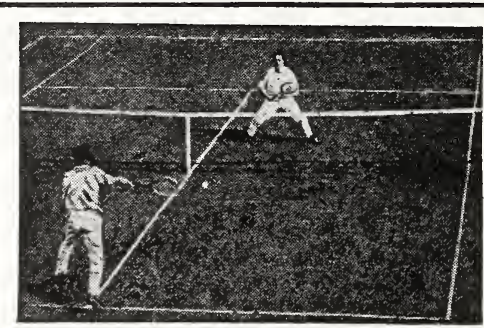

Athletic Field Grass Seed

A combination of deep-rooting, fineleaved grasses, best adapted for baseball, football and cricket grounds. Qt. 35c, 4 Qts. \$1.25, Pk. \$2.25, Bu. \$8.00
B U I S T' Lawn

Restoring Grass Seed

N almost every Spring of the year there are bare spots caused by ice or exposure d u $\mathrm{r}$ in $\mathrm{g}$ the W in $t$ e $r$ months. These bare spots may be quickly renewed by sowing this mixture which is made the soil and at the same time produces a beautiful green turf throughout the season. The grass should not be cut too often or too closely until it becomes established. Sow 4 bushel per acre. Qt. 35c, 4 Qts. $\$ 1.25$, Pk. \$2.25, Bu. $\$ 8.00$. up of grasses that will grow rapidly. The best time to re-sow is very early in the Spring, or seed may also be sown with excellent results in the Fall, during the month of September. Qt. 35c, 4 Qts. $\$ 1.25, \mathrm{Pk}$. $\$ 2.25, \mathrm{Bu}$. $\$ 8.00$.

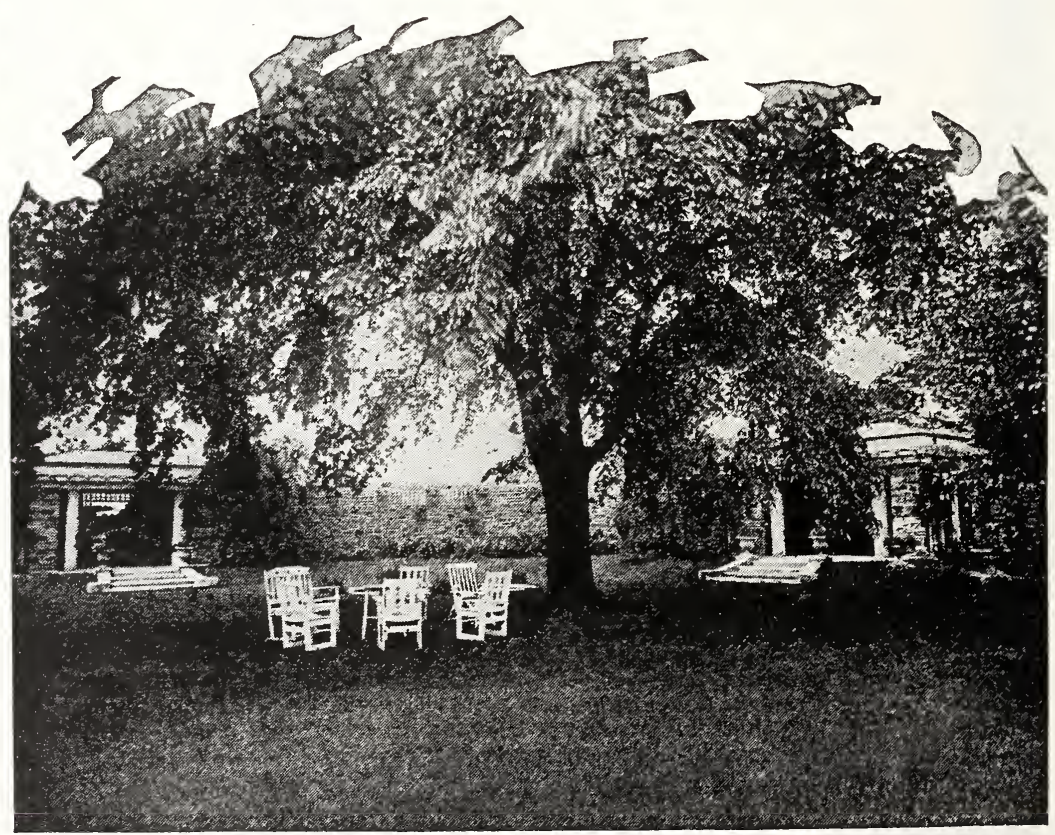




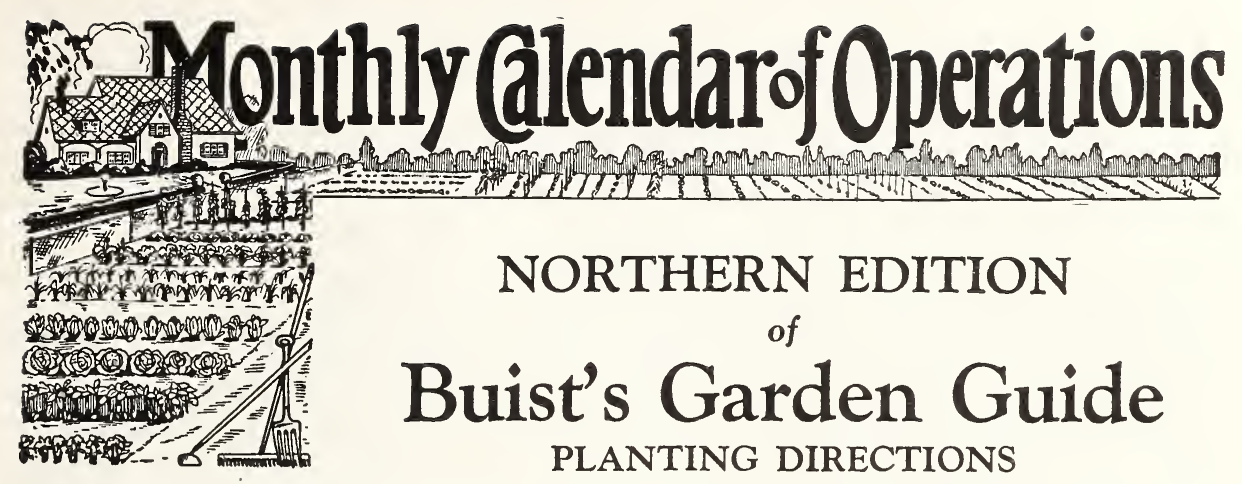

The active gardening months in the North are March, April, May, July and August. Monthly operations cannot be accurately given for the entire territory, but the following give suggestions of cropping about the period they should be attended to in latitudes of the Middle States. Adaptation to various States can be observed by noting the conditions of the climate and season.

A chart of all the principal vegetable seeds will be found on page 13, giving proper planting depths and distances apart, seed required and weeks to maturity. Further detailed instructions are contained throughout our GARDEN GUIDE, alphabetically arranged, under the various varieties of both vegetable and flower seeds.

\section{JANUARY}

Out-door work is necessarily limited, as snow and ice abound and ground is frozen, but there are important things that can be attended to in order to be in readiness for Spring operations. Overhaul all tools and implements; arrange and clean up your barn and out-buildings; haul manure to the fields where it will be required; prepare compost for top-dressing; prune your orchards and fruit trees, trim up your hedges; top-dress your asparagus beds with well-decomposed manure to be forked in as soon as the frost is gone. A top-dressing of salt is also valuable.

Lawns may be improved by a good top-dressing as soon as the leaves are gathered. Wood ashes, bone meal or any prepared manure is preferable to barnyard or stable manure, as the latter generally contains many weed seeds. By early covering the ground with manure, to prevent its freezing too deep, you will also be able to have your trenching and subsoiling done this month. Poles for Beans and Peas should be made ready for use. Forcing beds, with growing crops of Lettuce, Radish, etc., will require daily attention.

\section{FEBRUARY}

Very little can be done this month in the way of out-door gardening, but every family having a garden of any pretension should have a hot-bed. Prepare as instructed on page 12. This is a simple and cheap method of procuring strong, healthy plants of every variety of vegetables desired for transplanting in proper season without the trouble of hunting them up, and without the risk of buying plants that have been grown from inferior seeds. Time of sowing depends entirely upon the weather. If extremely cold, defer to the last of the month. Great care must be observed that the bed is of a proper temperature to insure the germination of seeds, especially the Egg Plant, which always requires a stronger heat than any other variety. Sow Buis's's Improved Large Purple. Also the Copenhagen Market, Charleston Wakefield and Jersey Wakefield Cabbage will give you a full supply for early use; also sow Buis's's Veribest Cabbage Head, Big Boston, Iceberg and New York Lettuce; Market Champion, BursT's "Earli-Belle" and Stone Tomatoes; Snow ball and Paris Cauliflower; the Buisr's "Early Money," Scarlet Turnip White Tipped, Long Scarlet and White Box Radish; the Ruby Giant and Bell or Bull Nose Pepper. It is necessary that the young plants are carefully protected from frost, cold and 
chilly winds, but they should also have an abundance of air to prevent them from becoming drawn or spindly. Therefore air them only during the middle of the day and protect the sash with mats or other coverings at night.

\section{MARCH}

This is the first of the active Spring months with the gardener, and in many localities it will be early enough to start a hot-bed. Those who have started their hot-bed must attend to it carefully. The care is not great, and will soon become a habit, but it must be given promptly and without fail. All plants under glass require attention, and air must be given at every favorable opportunity. The sun-heat on a close-confined frame will soon destroy the plants, and neglecting to close them on a raw, cold day will check their growth, and possibly injure them beyond recovery. Watering must be attended to. Use tepid water; and keep the soil loosened, which will greatly stimulate the growth of the plants. Seedlings, when large enough, should be transplanted into other frames, setting them out at least an inch apart, and for this purpose a cold frame will answer. If not transplanted, they should be thinned out. For the smaller homes, whose wants are less than a hot-bed would supply, we suggest the use of window boxes. These, well drained with broken crocks and filled to within an inch of the top with good garden soil, may be sown with such varieties of early vegetables as Cabbage, Cauliflower, Egg Plant, Lettuce, Pepper, Tomato, etc.; you will then have a supply of vegetable plants fully a month earlier than by waiting for out-door sowing, as your plants will be ready to set out at the time you would otherwise sow them.

In no branch of business is industry more important than in gardening. Results cannot be secured unless you care for your soil. Plow and subsoil it, or spade it at least twenty inches deep in the early spring and remember that plenty of manure and muscle are the important levers required in raising profitable crops.

If you have an early Spring, sowings may be made of the following varieties in the open ground:

Peas-Buist's Early Morning Star.

Beets-Cosbys Egyptian, Eclipse, Buss's Extra Early, Buis's's Perfect Model and Detroit Blood Turnip.

Cabbage-Set out the plants that you have wintered over in cold frames.

Carrot-Sow early Scarlet Horn, Half-Long Scarlet, and Bursr's Rubicon.

Celery-Sow Celery and Lettuce; also transplant Lettuce seedlings from winter frames.

Radish-Buist's Truckers “Early Money," BuisT's Early Scarlet Turnip, French Breakfast, Early Scarlet Globe and White Box.

Onion Sets-Select the smallest size, as the large ones shoot to seed. If you desire to grow large Onions from seed, and weather is favorable, sow thinly on rich soil the last of this month. Select the Mammoth White King and Yellow Prize-Taker. The two latter are very large Italian varieties, and of a very delicate flavor. The Buist's Yellow Globe Danvers, Red Wethersfield, and the Southport Red, White, and Yellow, are the varieties, however, generally sown to produce full-grown Onions.

Parsley-Sow Buist's Garnishing and Moss Curled. The Single or Plain Leaved is hardier, but has a stronger flavor.

Potatoes-For an early crop, select strong tubers of Houlton Early Rose, Irish Cobbler and BuIs's Early Sunrise; cut them into sets a few days before planting.

Spinach-Sow Buist's Perfection Curled, as it surpasses all other varieties.

Turnip-Sow the Early White Flat Dutch, Buist's Purple Top Globe.

Asparagus-New beds should now be formed.

Rhubarb Roots and Horse Radish Sets-Plant. Fruiting trees and plants should also be planted. 
If you desire to form a new lawn, sow as early as the soil can be plowed and well pulverized, and seed down with BuIsT's Evergreen Lawn Grass. It will make a very handsome appearance in sixty days, and form a fine sod by July. There is no seed sold in which there is so much deception as Lawn Grass; therefore purchase Buist's Evergreen, which is guaranteed to please you.

The above remarks apply only to an early Spring; and it is frequently the case that March work is deferred until April, on account of the lateness of the season; but if the weather is at all favorable, follow them. To secure early crops it is worth a venture. If you fail, you have ample time to re-seed.

The Flower Garden-Do not neglect your lawn. If not attended to before, complete it now. Rake off all dead grass and old leaves, and give it a top-dressing of BuIsT's Lawn Enricher, about 400 pounds to the acre. Beds planted with Hyacinths, Tulips, etc., may now have their covering shaken up and on warm days taken off entirely, re-covering them only on the possibility of a cold spell. Prepare vacant beds for bedding plants by deep culture, moderately enriched with manure; spade them up and leave them in this condition until the time for planting; change, if possible, the arrangement of your flower beds from last year, giving your garden a more diversified and better appearance; remove the straw coverings from roses and other plants, finish all pruning, and make a general clearing up for Spring operations.

\section{APRIL}

This is really the gardening month of the North. Time lost now cannot be recovered. If the important hints suggested in the previous month's operations have been taken advantage of, you are now ready for active duty, and have perfected your plans for the season. Those whose situations were favorable, and started their hot-beds in February, should have fine plants now ready for planting out from the cold frame; if well hardened off and weather settled, they will start and grow without a check. Transplanting to the open ground will vary with the locality. Cabbage, for instance, is not affected by cool nights, while Tomatoes and other tender plants would perish. While giving general instructions for culture, we can lay down no definite rule for exact time of planting and sowing, owing to the changeable seasons. What was recommended for March in a late season should be deferred until April. What may now be planted in light soil had better be deferred to a later period, on cold, heavy ground. A general clearing up, manuring and dressing the beds of Asparagus, Rhubarb, and other permanent roots and plants, if not already done, should have early attention this month. In all cases, when it is possible, use a spading fork around the roots in preference to a spade, "and remember it is useless to expect good crops from barren soil." Plenty of manure and muscle are the important levers required in raising profitable crops after sowing Buist's Seeds. The following varieties of seeds are suitable for present planting:

Beet-Crosby's Egyptian, Early Eclipse, Buist's Extra Early, Detroit Blood Turnip, and do not overlook BuIsT's Perfect Model. Those who have never raised the Swiss Chard we advise to try it this season; this variety may truly be called "Cut and Come Again." The leaf stalks are prepared similar to Asparagus, and by many it is greatly preferred-in fact, it is a delightful dish.

Beans-Bush, or Snap-Shorts, in sheltered situations. Sow, about the middle of the month, Stringless Green Pod, Bountiful, Buist's Prolific Stringless, Best of All Stringless Wax, Improved Golden Wax. The first three are the earliest and most productive of the green-podded varieties; but the Wax beans, with their beautiful golden stringless pods, are decidedly preferable, and besides the Best of All Stringless Wax are earlier than any other variety, producing pods in favorable weather in less than six weeks from time of planting, and are not liable to rust.

Cauliflower Plants-Transplant from frames. Although they are more successfully grown in forcing beds or frames, yet in many localities where the atmosphere is moist, they can be cultivated successfully as a garden crop. The most desirable varieties are the Early Erfurt, Early Snowball and Danish Dry Weather.

Cabbage-Sow Buist's Improved Drumhead and Flat Dutch. These are the finest stocks of late Cabbage grown, and are always sure to produce fine large heads. They 
have been awarded as many as twenty-two premiums in one season. There is nothing equal to them. They are put up and sold only under our seal in packets, $1 / 2$ ounce and ounces; also $1 / 2,1 / 4$ and 1 -pound cartons. Seed of these varieties offered in any other way is spurious. As the cabbage-fly is very destructive to the young plants, it is the safest plan to sow plenty of seed, and always select the strongest looking plants for your planting. If the Spring sowings of early varieties have not yet been transplanted out from the hot-bed, attend to it at once.

Carrot-Sow Early Scarlet Horn, Half-Long Scarlet, Scarlet Chantenay and BuIsT'S Long Orange; the latter for main crop, either for garden or field culture. They produce very large, smooth roots.

Celery-Sow Easy Blanching, Golden Yellow, Self-Blanching and White Plume.

Cucumber-Plant in sheltered situation Perfection White Spine and London Long Green. Transplant your Egg Plants and Tomatoes from frames, if not already attended to, and another sowing of the latter can be made for a later crop. Select the BuIsT's New Monarch, Prize Stone, Buist's Market Champion and Greater Baltimore for this purpose, as no other varieties will please you as much.

Lettuce-Sow, and also transplant from Spring or Winter beds. There are very few cultivators who grow Lettuce to perfection. The soil must be of the richest nature and grown quickly, in order to produce crisp heads. Select Big Boston, Simpson, Hanson, May King, and Buist's "Veribest" Cabbage Head; and for sowing to come in late, select the Salamander and New York.

- Onion Sets-Plant as soon as the ground can be worked; one quart will plant a 50 -foot row; use 8 to 10 bushels to the acre.

Onion Seed-Sow thickly for producing Onion Sets, and thinly for growing largesized Onions. The soil for the latter cannot be too rich. The varieties for producing sets are Yellow Strasburg and White Silver Skin. For producing full-sized Onions the first year, sow Red Wethersfield, Yellow Danvers, Prize-Taker, and Southport Globes.

Parsley-Sow; the Buist's Garnishing and Moss Curled-they are the best. The single or plain-leaved, although not as desirable for garnishing, is more hardy and has a much stronger flavor.

Parsnip-Sow. Should you have a surplus, feed to your cattle, as they enjoy them.

Peas are a very important and a standard crop in every garden and must not be overlooked; to keep up a regular succession of crops make sowings every two weeks throughout the season, and put in plenty of them, as they are a general favorite. There is a great difference in the quality of this vegetable, and it would be folly to grow inferior varieties when you can obtain those of a superior quality at the same price. We will here remark, and beg that it shall be observed, that where the ground is dry there should be water run in the drills before the peas are sown.

Form the drills 2 feet apart. and 3 inches deep, dropping the Peas to stand about $1 / 2$ inch apart. Cover up, and the moisture will at once vegetate the seed. As soon as up, hoe well, and keep clear of weeds; when they are about 1 foot high stake them.

Plant Buist's Early Morning Star-Sold only in Sealed Packages. 1 lb., 2 lbs., $7 \mathrm{I} / 2$ lbs., $15 \mathrm{lbs}$., $30 \mathrm{lbs}$. and $60 \mathrm{lb}$. sacks. Seed offered in any other way is not genuine. It is the earliest known variety, producing large crops of sweet and luscious Peas. The Morning Star is our latest improvement in Extra Earlies. It is not only the earliest, but the most productive and finest flavored Extra Early known. The Gradus, Thomas Laxton, American Wonder, Nott's Excelsior and Telephone are the cream of wrinkled varieties. They produce large and well-filled pods of luscious flavor.

Peppers-Transplant from frames.

Potatoes-Select and plant those grown in Eastern localities; they will always produce much finer Potatoes. We annually grow our stocks in Maine. Plant Houlton Early Rose, Beauty of Hebron and Irish Cobblers; and for late or general crop, State of Maine and Green Mountain.

Radish-Continue sowing the- red varieties up to the 20th; if sown later they are liable to grow spongy and shoot to seed without forming any root. White Icicle, Chartier 
and White Strasburg best for sowing the last of the month; they will be crisp and tender.

Salsify, or Oyster Plant-Do not overlook sowing this important vegetable; it is annually becoming more popular. The BuIst's Mammoth is the most desirable variety. Sow Perfection or Long-Standing Spinach for succession.

Spring Turnips-Always sow as early as the weather permits. They require quick growth, otherwise they will be tough, spongy and useless.

\section{MAY}

As this is the month on which you principally depend for your important supply of vegetables, it would be folly to sow seed from doubtful sources. Always avoid the commissioned boxes of seeds left on sale at country stores. They are generally old and accumulated stocks, with their germinating qualities weakened with age, and even when they grow (which is seldom) they almost invariably produce vegetables of an inferior quality. If such seeds had only the power of speech, they would tell you that they are weak and sickly, owing to their long and weary confinement in their close packets, and from the infirmities of age. Next to old seeds, the greatest enemy of the garden is weeds. They are now ready to overgrow your crops unless frequently disturbed. Keep your cultivator and hoe in active service, and if you have not already a good hand cultivator, purchase the Planet Junior, which beats them all. It will do the work of three or four hands, and do it better. It will pay its cost in a week.

By carefully examining the directions given for April, you may find something that you have overlooked. If so, attend to it at once. The majority of vegetables having now been sown, and others transplanted in favorable situations, their proper cultivation and thinning out when too thick must have your attention. Examine your seed beds closely, and if any sowing has failed, re-seed at once. All plants in frames will require plenty of air and water, and gradually harden off before transplanting to the garden. All the more delicate seeds can be sown as both soil and atmosphere are mild and pleasant, and they will germinate freely.

Plant Lima Beans, but bear in mind, unless the soil is warm they will not germinate; also plant Bush or Snap-Short varieties. The BuIst's Prolific Stringless, Green Pod Stringless and the Golden Wax are the best; and do not overlook planting the BuIsT'S Ideal Pole Lima and Fordhook Bush Lima, as they are by far the best sorts.

Beets-Sow; select the dark-blood varieties, such as Detroit Blood Turnip, Half-Long Blood. They are the best for Fall and Winter.

Cabbage-The late varieties can still be sown, if not attended to last month. The early sowings will be sufficiently large to plant out the last of this month. Select the largest and strongest plants. The small ones can be transplanted later for a succession.

Stock Beets-Such as Mangel Wurzel and Sugar, should now be sown for Winter feeding. It is impossible to overestimate the importance of this crop. Its yield is enormous (from 600 to 800 bushels to the acre), and its value to the farmer great. Select Buist's Golden Gíobe if your soil is shallow; BuIst's Mammoth Long Red, Golden Tankard and Chirk Castle Mangel if your soil is deep and rich.

Carrot-Continue sowing the Half-Long Scarlet for table use, and Buist's Long Orange for stock feeding.

Cauliflower-In frames will require copious watering, and if weather is settled, the glass can be removed.

Celery-Sowings may be repeated, and weed the seed-beds of last month.

Corn-Plant Cory, Crosby's, Minnesota, Golden Bantam and Country Gentleman.

Cucumbers-Make a general planting. Sow. Burst's Perfection White Spine and Buist's Long Green.

Kohl Rabi-Sow. This vegetable is a great favorite with the European gardeners, and if properly prepared for the table is fine.

Lettuce-Sow in rows, and thin out; Iceberg, BuIsT's Sensation and Salamander. The latter will give you heads two pounds in weight; is delicate and tender.

Melon-Plant Buist's Selected Rocky Ford, Emerald Gem and Fordhook. The latter 
is the finest of the yellow flesh varieties. For Watermelon, select the Tom Watson, Kleckley's Sweet, Halbert's Honey and Florida Favorite.

Parsnip-Sow early for general crop, and thin out last month's sowing.

Peas-Sown now should be planted deeper than usual to prevent dry weather from injuring their roots. A crop thus planted will produce more abundantly and continue in bearing longer. Select the wrinkled varieties.

\section{JUNE}

The principal occupation of the gardener this month will be battling with weeds, not only to destroy them, but at the same time stirring up the soil, letting light and air into the earth, and imparting life and vigor into the growing plants-bear in mind that good cultivation is almost equal to good manuring.

The earth is the natural mother of weeds, and will require your utmost vigilance to destroy them. The use of hand cultivators, to assist in the cultivation of the soil and the extermination of weeds is very important. They do their work easily and thoroughly and are back-savers, economizing both time and labor. Use the Planet Double Wheel Hoe; it will save its cost in a week.

Asparagus-Beds keep free from weeds, particularly beds recently planted. Cut away all seed-bearing stems, as they are exhausting to the roots.

Bush, or Snap-Short Beans-Plant every two weeks for a succession. The Giant Stringless Green Pod, Green-Pod Stringless and Best of All Wax are the most desirable for Summer planting. If your Lima or Wax Pole Beans have not come up satisfactorily, you are still in time for replanting. It is always a good plan to start the Lima in cold frames or place them between sods, and transplant them, when sprouted, to prevent any such disappointment, as they will not withstand cold, moist weather.

The potato bug is now very industrious. $\mathrm{He}$ is a good feeder, but a far better propagator; therefore look out for him, and dust the foliage with a mixture of one-eighth Paris green to seven-eighths plaster, or a preparation called slug-shot; these are really the only applications that will settle him.

Beets-Thin out those already sown and sow Buist's Perfect Model for a succession. Young plants that are thinned out can, during moist weather, be successfully transplanted. If you are growing Mangel Wurzel for your stock this season, give them every attention. Thin out, and keep thoroughly cultivated; with a little care and good treatment their growth will astonish you.

Cabbage-Transplant May sowings, which will head in September and October.

Celery-If required for early use, transplant now-a good layer of rotten manure at the bottom of the trench is always necessary. See that the plants are well watered during dry weather; there is nothing better for this purpose than soapsuds.

Cucumber-Sow again for succession the Perfection White Spine and Buist's Long Green. Those for early pickling can be planted the last of the month. Select the Jersey Pickle for this purpose.

Sugar Corn-Plant every two weeks for a succession. Select the Country Gentleman, Mammoth and Stowell's Evergreen Sugar.

Endive-Sow for transplanting for Fall use.

Leek-Transplant or thin out; transplanting always produces finest results.

Squash can still be planted. Tomato vines should always be trained to trellises, as they will produce much finer fruit and crop more abundantly; if they grow too strong pinch off the points of shoots.

Ruta Baga Turnip-Sow from the 20th of this month to the 20th of July; there is nothing superior in the vegetable line for Winter feeding. With fair culture they will produce immense crops, and we cannot prevail too urgently upon the farmer the great importance of extending their culture. They are not only profitable but invaluable to all agriculturists, being relished by all kinds of stock. Sow BuIst's Improved Purple Top Yellow; it is the largest growing variety, producing the finest formed roots, and will be found superior to any other stock in this country. The turnip-fly is very destructive to this crop, and frequently eats off the young plants as fast as they make 
their appearance. Watch the crop and dust with plaster. Do not permit your garden to be littered up with any crop that has ceased bearing; remove it at once to make room for another. By attending to this closely you will be surprised with the various successions of crops that can be produced in a small garden.

\section{JULY}

Weather during this month is generally hot and dry, and men are generally opposed to much exertion; but brace up and take a glance over your garden, be it large or small. See what has been omitted, and have all oversights quickly rectified. Weeds must always claim your constant attention. When watering is necessary to be done, do it thoroughly; sprinkling of the surface soil is really an injury. A water cart on wheels will be found valuable. Where you have planting to do-Cabbage, for instance-make a strong puddle of clay and loam and dip the roots into it. Even in the driest weather not more than five per cent. will fail to grow. Prepare the ground for replanting where early crops have been removed; some seeds may still be sown. When the soil is dry, settle it firmly by treading with the feet.

Beet-Keep well thinned and thoroughly clear of weeds. The foliage of young Beets is an excellent substitute for Spinach.

Cabbage-Set out for late crops. If the weather is dry, dip the roots in puddle, as above, before planting; but it is always best to select moist weather for their transplanting.

Carrots-Give their final thinning. Keep the hoe or cultivator constantly going until the leaves are large enough to cover the ground.

Celery-Set out for your main crop. Cut off the tops to within two or three inches of the crown of the plant before planting.

Corn-Plant Country Gentleman, Mammoth and Evergreen Sugar for a succession.

Cucumbers-Plant the Jersey Pickle for pickling purposes.

Egg Plant-An occasional watering of liquid manure or soapsuds greatly facilitates their growth, if weather is dry. Mulching the plants with cut grass will be of advantage.

Tomato-Train, or where no support is given them, place some pea haulm or straw under the vines, to protect the fruit in ripening. If the foliage is very strong thin it out to allow the fruit to ripen.

Endive-Sow. Cultivate your Melons, Squashes and Cucumbers until the vines cover the ground. Look closely for the squash bug on all young plants, as they are very destructive. Ruta Baga sown last month should now be thinned out. If you have overlooked sowing them you are still in time unti! the 20 th to the 25 th. After that date the season is generally too short to form large roots.

Turnips-A portion of your sowings should be made the last of the month, just before or after rain. The Red or White Flat Strap-Leaved are the best flat varieties; but Buist's Mammoth Red Top White Globe is the best of all; sow it, it will please you. They are of the easiest culture, and are generally sown broadcast. To those who desire to cultivate a choice Yellow Turnip, we strongly recommend the Yellow Globe for field culture, or the Golden Ball for the garden; the former should be grown in drills, and the latter broadcast.

\section{AUGUST}

This is the last of the gardening months of Summer, and the time for sowing all varieties of vegetables that require but a short season to mature their crops-such as Peas, Snap Beans, Spinach, Corn Salad, Radish, Turnip, Lettuce and Kale. The most important and most extensive sowings, however, are Turnips, and sowings should be completed, if possible, before the 20th; but all globe-shaped varieties, such as Mammoth Red Top Globe, White and Yellow Globe, Yellow Aberdeen and Amber Globe, should be sown as early in the month as possible. The best of all the globe varieties is the Buist's Mammoth Red Top Globe-sow it, by all means. It is becoming very popular and cannot be recommended too highly.

The flat varieties, such as Red Top and White Flat Dutch (Strap-Leaved), will frequently be in time if sown as late as September 1st; but seeding so late is not advisable. The turnip-fly is a very destructive insect on the Ruta Baga and Turnip crop, frequently 
eating off the young plants just as fast as they make their appearance above ground. Examine closely, and if they are discovered, dust them with plaster. Frequent failures are often experienced in securing a good stand of plants; do not become disheartened, but re-seed at once; after they form their first rough leaf the crop is safe. As there is so much spurious Turnip Seed now offered for sale, it would be advisable to purchase your supplies from us, put up in $1 / 4,1 / 2$ and 1 -pound sealed cartons, as every grain of seed we offer has been grown from transplanted and selected roots.

Peas-Plant Buist's Early Morning Star from middle to last of the month; all later varieties, if planted this month, are now liable to mildew, and will produce no crop.

Snap-Short Beans-Plant especially the Giant Stringless Green Pod, Stringless Green Pod, Refugee or 1000 to 1, and Best of All Wax.

Spinach--Sow Perfection Curled; it is the best variety; sow also Corn Salad and Green Curled Kale. Radish-Early Scarlet Turnip, Early Scarlet Globe and White Box, also Round Scarlet China, Chinese Rose and White China for Fall or Winter use.

Lettuce-Sow Dutch Butter and Big Boston in drills for heading late. Early plantings of Celery should now be earthed up, and later plantings, if dry, should be well watered. This crop always pays well for any extra attention bestowed upon it.

Tomatoes planted late should have their foliage thinned out to permit the fruit to ripen more evenly. Those who have acted upon our suggestion and planted the Monarch Market Champion, will now find that we have not praised them too highly. Lima and other Pole Beans will require pinching back when overtopping their support. Late sowings of Beet should be thinned out and well cultivated. The growth of Cabbage will be greatly stimulated by keeping the soil well tilled.

\section{SEPTEMBER}

This month is still an active one with the gardener.. Seeding time is almost over, but the time for harvesting of root crops and the covering of others for Winter protection will soon be here; therefore important work should be well in hand and finished promptly. During August and September you have full opportunity for comparing and examining crops, and noting impurities in those you have grown. If you purchased your seeds from Buist and have given your crops good soil and good culture, your garden has proved a success, and impurities in your vegetables a rare occurrence; but if you have overlooked the important requisite of obtaining good seeds, and have planted those sent to the country stores to be sold on commission (which are generally either old or of inferior quality), you will find that a portion of your season's labor has been bestowed on the cultivation of worthless crops. It would be wise, therefore, in future, to remember that the best seeds are always the cheapest, and Buist's are always grown by him from Selected Seed Stocks, and are therefore of the very finest quality. Order them; they are the cheapest and best for you. All growing crops will still require your attention and cultivation; preparations made for the sowing of Cabbage, Lettuce and Cauliflower, to produce plants for Spring planting; sowings of Buist's Extra Early Jersey Wakefield and Charleston Wakefield should be made about the middle of this month. On the approach of cold weather the plants should be lifted and stored in cold frames, and transplanted out in early Spring. Sow also Early Snowball Cauliflower, which can be transplanted into forcing or cold frames for heading during Winter and Spring, or stored similar to Cabbage for planting out. Turnips, the Red Top and White Flat Dutch, may still be sown during the first week of the month, if the sowings made last month have not proved a success. They will now grow rapidly, and have fair prospects of forming roots if the season does not prove a short one. Celery should be earthed up. Endive tied up for blanching. Sow also Corn Salad, Spinach and Kale to remain out all Winter. Sow also Buist's Early White Forcing, Big Boston, Buist's Unrivaled and Dutch Butter Lettuce, which can be transplanted into cold frames or forcing beds for Winter and Spring heading, or transplanted on ridges in the garden and covered with straw or litter during Winter. This is the month for the formation and seeding of lawns. Sow BuIsT's preparation of grasses for this purpose, and read remarks on page 92 . September sowing is decidedly 
better than sowing in Spring, as the young grass becomes thoroughly established before cold weather, and gives it the advantage of an early Spring growth; it is then not so liable to be damaged from warm weather.

\section{OCTOBER}

The active duties of the gardener are now rapidly lessening, but an industrious man always finds plenty to do at all seasons of the year. The principal duties of the present month will be the harvesting of such root crops as are matured, the transplanting of Lettuce both into cold frames and ridges for Winter and Spring heading; also Cauliflowers into forcing frames for Spring use. Cabbage sown last month pull and store in cold or warm frames for Spring planting. Spinach may still be sown; also Early Scarlet Globe Radish in cold or warm frames, between rows of Lettuce; Celery should have its final earthing up. Trench all vacant ground, to remain in that condition until Spring. Now is also the time for planting all German Bulbs, such as Hyacinths, Tulips, Crocuses, etc., but to be successful in their cultivation the soil should be light and rich. If inclined to be heavy, mix it with sand and leaf-mold from the woods. As soon as cold weather sets in, cover the beds with a coating of well-rotted manu-e, which should be taken off in Spring, and surface soil loosened and finely raked. We annually import from Holland large supplies of Bulbs, and your orders will be filled promptly. There are no flowers that will repay you as much as Hyacinths, Tulips, Daffodils, Crocuses and the innocent little Snowdrops. These are the flowers that bloom in the Spring and which are so universally valued and admired, the planting of which is so often overlooked until too late. Send for a Bulb catalogue and order at once.

\section{NOVEMBER}

Gardening operations are now mostly over for the year, and the finishing touches may be given to your garden at once. Plants in frames should be aired-all root crops must be lifted at once, and carefully stored either in pits outdoors or in root cellars. Cabbage sown in September, if not already placed in cold frames for Spring planting, should be attended to at once; Cabbage which has headed lift and place in trenches, and cover over with litter for Winter use. Celery, Turnips, Beets and Carrots lift and store for Winter use. Parsnips and Salsify, although perfectly hardy, should now be lifted for convenience. Asparagus beds give Winter dressing. If you have grown a supply of Mangels, Turnips and Carrots, they will now come in very useful for stock-feeding, but to avoid flavoring either milk or butter, feed them only at milking time. They should, however, always be steamed before using.

\section{DECEMBER}

Winter may now be said to be upon us in full force, and but little can be accomplished outdoors except in making a general clearing up about the place. Your forcing and cold frames should have careful attention. Other supplies of Lettuce should be transplanted in frames, and other sowings of Radish made; but there are some minor details that generally suggest themselves to all thinking men that should always have attention. The monthly hints that we have given are merely suggestions for the inexperienced; competent gardeners are familiar with the various duties of each season without referring to them.

This is also the month for making out your Spring list of seeds required. Remember that the foundation of a good garden is first good seeds, and then good culture. Look out for what are known as cheap seeds. Do not expect to purchase for fifty cents per pound that which costs a dollar a pound to grow. There are lots of seeds annually sold that there is nothing to recommend them but their first cost. The gardener generally finds them very expensive, for if they grow, the crops produced are inferior.

By using a little forethought and study on rainy days or Winter evenings, you will be able to greatly lessen your Spring labor when work comes upon you with a rush. If you do not go systematically at work now, and have everything in order, and know exactly what you intend doing in the Spring, you will accomplish but little satisfactorily; important crops will be entirely overlooked, and many others will be seeded too late to produce profitable returns. Look carefully over your tools and implements if you have not already done so: Replace those which are lost through carelessness or negligence, and see that all are in proper order. Pruning and grafting can still be done, and seeds required, if not already ordered, should be purchased at once; examine our Garden Guide carefully in making out your list, in order to select those which are the most desirable. 


\section{Making a Hotbed}

In order to secure a supply of early vegetables, a hotbed frame is indispensable. It can be constructed by any one, at a very small cost; it consists of a wooden frame, generally six feet wide, and from six to sixteen feet long, according to the supply of early vegetables required; one side to be at least six inches higher than the other; the frame to be sub-divided by cross-bars; and each division covered by a glazed sash; the sides and ends should be joined by hooks and staples, to admit of its being taken apart and stored away when not required. After completion, place it on the manure-bed, prepared in the following manner: The frame should face the south or southeast; fill in about ten inches of rich pulverized soil, and allow it to stand a few days, giving it air by slightly raising the sash so that the fiery vapor or steam may escape. The seeds of Cabbage, Cauliflower, Egg Plant, Pepper, Tomato, and many other varieties may be sown, and the plants planted out as soon as the frosty weather is over.

Preparing Manure for Hotbeds.-Fresh stable manure only; not exceeding six weeks old, is suitable for this purpose. Turn it over into a compact heap, protected from heavy rains or snow; allow it to remain so for about eight days, when it should be made up into the requisite form to suit the frame. To insure more uniform heating a layer of straw is used to cover the manure. Egg plant requires strong heat to vegetate it; for such the hot material will require to be two feet thick. Where the ground is quite dry, a very good method is to dig a space about eighteen inches deep, and put the manure therein; tramp it firmly and evenly, place thereon the frame and sash; put in the rich earth, and in about four days sow the seed, having previously stirred the earth freely to destroy any seeds or weeds therein.

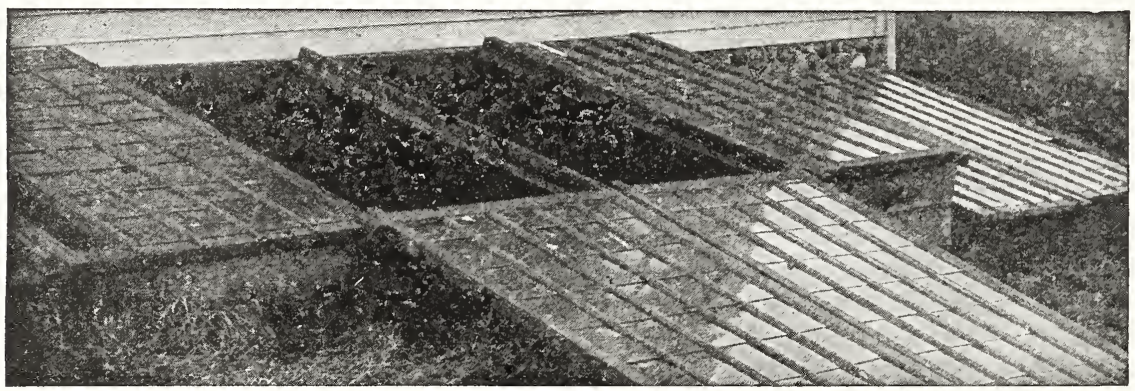

The Cold Frame is a simple construction of boards for wintering Cabbage, Lettuce, Cauliflower, or Broccoli, for planting out early in Spring. Select a dry Southern exposure; form a frame from four to six feet wide, and as long as is required. The back should be fourteen inches, and the front six inches high, with a cross-tie every six feet. Seeds of Cabbage, Lettuce, Cauliflower, and Broccoli, sown in the open border early in September, will be ready to plant into the cold frame about the end of October. The soil should be well prepared and smoothly raked before planting.

The Cold Pit-This is a structure in very general use for growing Cauliflowers during Winter. The situation must be dry and well sheltered, having a south or southeast exposure. Dig out a space two feet deep, and eight feet wide, if for brick, and nine feet wide if for stone. Build the back wall four and a half feet high; that will be two and a half feet above ground, and three feet high in the front. If the ground is not dry, and is subject to underwater, and draining cannot be effected, do not dig so deep, and surround the walls with two feet thick of earth, which will keep the frost from penetrating them. If Cauliflower is to be planted, put into the pit three feet of leaves from the woods; tramp them firmly, over which put one foot of rich earth; after it remains for two weeks it will be ready for the plants. Six plants for each sash of four feet will be enough. The space between may be filled up with Lettuce plants or a sowing of Radish.

The Hot Pit-Constructed in the same manner as the Cold Pit, but having the appliances of artificial warmth, either by hot manure and leaves, about half and half, firmly trampled into the bottom, two and a half to three feet thick; or one-half fresh tanner's bark, half dried, mixed with hot manure, is very efficient, over which place about one foot of earth. In about two weeks the heat will have subsided sufficiently to admit of Cucumbers being planted, or any other seeds or roots requiring artificial warmth to forward their growth. 


\section{VEGETABLE PLANTING CHART}

\section{For Philadelphia and Equivalent Climate}

\begin{tabular}{|c|c|c|c|c|c|c|}
\hline \multirow{2}{*}{ Vegetable } & \multicolumn{3}{|c|}{ Planting Distances } & \multicolumn{2}{|c|}{ Seed Required } & \multirow[t]{2}{*}{ Weeks to Matur } \\
\hline & $\begin{array}{c}\text { Apart in } \\
\text { Row }\end{array}$ & $\begin{array}{c}\text { Between } \\
\text { Rows }\end{array}$ & Depth & Per 100 Ft. Row & Per Acre & \\
\hline tichoke. & It.. & $10 .$. & . & $1 \mathrm{oz}$. to $500 \mathrm{pla}$ & & 1 yedr \\
\hline Asparagus, Seed & 2 in... & $2 \mathrm{ft} . .$. & 2 in. & 1 oz........... & 4 lbs.. & 3 to 4 years \\
\hline Asparagus, Roots. . & $2 \mathrm{ft} . .$. & $4 \mathrm{ft} .$. & & 50 roots.. & 5445 roots... & 2 years \\
\hline eans, Bush... & $4 \mathrm{in...}$ & $2 \mathrm{ft}$. . & 2 in... & 1 qt..... & $11 / 2$ bu... & 6 to 8 week \\
\hline ans, Bush Lima. . . & 6 in.... & $2 \mathrm{ft} .$. & 1 in.... & $1 \mathrm{pt......}$ & $1 \mathrm{bu} . .$. & 12 to 14 week \\
\hline ans, Pole... & $3 \mathrm{ft} . .$. & $4 \mathrm{ft} .$. & 2 in.... & $1 / 2$ pt. in hills. & $1 / 2$ bu.. & 8 to 10 week \\
\hline Beans, Pole Lima. . & $3 \mathrm{ft} . .$. & $3 \mathrm{ft} .$. & 1 in...... & 1 pt. in hills... & $1 / 2$ bu........ & 14 to 16 week \\
\hline Beets................. & 4 in.... & $11 / 2 \mathrm{ft} .$. & 1 in...... & $1 \mathrm{oz} . \ldots \ldots \ldots \ldots \ldots$ & 6 lbs......... & 8 to 9 week \\
\hline s, Mangels.. & 10 in.. & $21 / 2 \mathrm{ft}$. . & $11 / 2$ in.. & $1 \mathrm{oz} . . . \ldots \ldots \ldots \ldots$ & 5 lbs... & 18 to 20 week \\
\hline li........ & $2 \mathrm{ft} . .$. & $21 / 2 \mathrm{ft}$. . & $1 / 2$ in... & 1 oz. to 3000 plants. . & $4 \mathrm{oz} \ldots$ & 16 to 18 week \\
\hline sels Sprouts. . & $11 / 2 \mathrm{ft}$. & $21 / 2 \mathrm{ft}$. . & $1 / 2$ in.... & 000 plants.. & $2 \mathrm{oz} .$. & 16 to 18 week \\
\hline age, Early... & $11 / 2 \mathrm{ft} .$. & $2 \mathrm{ft} . .$. & $1 / 2$ in.... & 000 plants... & 4 oz.... & 13 to 14 week \\
\hline bage, Late..... & $21 / 2 \mathrm{ft} . \ldots$ & $21 / 2 \mathrm{ft} .$. & $1 / 2$ in... & 1 oz. to 3000 plants... & 4 oz.......... & 18 to 20 week \\
\hline Early........... & 3 in...... & $1 \mathrm{ft} . .$. & $1 / 2$ in... & $1 / 2$ oz... & 3 lbs......... & 8 to 9 week \\
\hline , Late... & 6 in... & $11 / 2 \mathrm{ft}$. . & $1 / 2$ in... & $1 / 2$ oz... & $21 / 2$ lbs...... & 11 to 12 week \\
\hline iflower..... & $2 \mathrm{ft} \ldots$ & $21 / 2 \mathrm{ft}$. . & $1 / 2$ in... & 000 plants... & 2 oz........... & 15 to 16 week \\
\hline ry.................. & $6 \mathrm{in} .$. & 3 to $4 \mathrm{ft}$ & $1 / 4$ in.... & 0000 plants.. & 40 & $18 \mathrm{tc}$ \\
\hline$c \ldots \ldots \ldots \ldots \ldots \ldots \ldots$ & 6 in... & $2 \mathrm{ft} . .$. & $1 / 4$ in.... & 000 plants... & $4 \mathrm{oz} \ldots$ & 16 to \\
\hline s.... & $21 / 2 \mathrm{ft} .$. & $21 / 2 \mathrm{ft}$. . & $1 / 2$ in..... & lants... & $4 \mathrm{oz} . \ldots \ldots \ldots$ & 14 to 15 week \\
\hline eet.. & $3 \mathrm{ft} . .$. & $3 \mathrm{ft} . .$. & $1 \mathrm{in} . .$. & 0 hills...... & 8 qts... & 8 to 14 week \\
\hline Salad... & 3 in.. & $1 \mathrm{ft} .$. & $1 / 2$ in.. & $1 \mathrm{oz} . .$. & 25 lbs.. & 7 to 8 week \\
\hline Cre & 4 in.. & $11 / 2 \mathrm{ft}$. & $1 / 4$ in.. & $1 \mathrm{oz} \ldots$ & $12 \mathrm{lbs} .$. & 4 to 5 week \\
\hline ater. . & 3 in.. & $1 / 2 \mathrm{ft} .$. & $1 / 4$ in... & $1 / 2$ oz... & & 8 to 9 week \\
\hline er...... & $3 \mathrm{ft} . .$. & $3 \mathrm{ft} . .$. & $1 / 2$ & 0 hills...... & 2 lbs.. & 9 to 10 week \\
\hline on.. & 5 in.. & $11 / 2 \mathrm{ft} .$. & $1 / 2$ in.. & $1 / 2$ oz... & 3 lbs.. & 8 to 9 week \\
\hline int.. & $2 \mathrm{ft} .$. & $21 / 2 \mathrm{ft}$. & $1 / 2$ in.. & 1 oz. to 2000 plants... & $4 \mathrm{oz} .$. & 20 to 22 week \\
\hline Endive..... & $1 \mathrm{ft} .$. & $1 \mathrm{ft} . .$. & $1 / 2$ in.. & 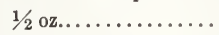 & $41 / 2$ lbs. . & 10 to 12 week \\
\hline & $2 \mathrm{ft} .$. & $2 \mathrm{ft} .$. & $1 / 2$ in... & $1 / 20$ & 3 lbs.... & 10 \\
\hline abi. . & 6 in.. & $11 / 2 \mathrm{ft}$. & ....... & $1 / 20$ & 41 & week \\
\hline 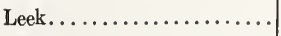 & 6 in. . & $1 \mathrm{ft} .$. & $1 / 2$ & $1 / 20$ & 41 & 14 to 16 week \\
\hline 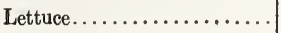 & $1 \mathrm{ft}$. & $11 / 2 \mathrm{ft}$. & $1 / 4 \mathrm{in.}$. & lants... & 41 & 7 to 8 week \\
\hline , Musk.. & $4 \mathrm{ft}$. & $4 \mathrm{ft} .$. & $3 / 4$ in. . & 0 hills...... & 31 & 12 to 14 week \\
\hline Vater....... & $8 \mathrm{ft} . .$. & $8 \mathrm{ft} .$. & $3 / 4$ in... & $2 \mathrm{oz}$. to 100 hills.... & 4 lbs... & 15 to 16 week \\
\hline d............ & $1 / 2$ in.. & $1 \mathrm{ft} .$. & $1 / 4$ in... & $1 \mathrm{oz} \ldots \ldots \ldots \ldots \ldots$ & $\ldots$ & 4 to 5 week \\
\hline & $1 \mathrm{ft}$. & $21 / 2$ & 1 & 102 & 81 & 9 to 10 week \\
\hline ed............. & 3 in.. & $1 \mathrm{ft} .$. & $1 / 2$ in.. & $1 / 2$ oz.... & 5 lbs... & 18 to 20 week \\
\hline Sets............ & 3 in. . & $1 \mathrm{ft}$. . & $1 / 4$ in... & 2 qts.... & 10 bu... & 5 to 6 week \\
\hline ey.............. & 2 in... & $1 \mathrm{ft} . .$. & $1 / 2$ in... & $1 \mathrm{oz} . \ldots \ldots \ldots \ldots \ldots$ & 3 lbs... & 12 to 14 week \\
\hline & 5 in.. & $11 / 2 \mathrm{ft}$. . & & z............... & $\ldots$ & 16 to 18 weeks \\
\hline & 2 in.. & $3 \mathrm{f}$ & 2 & $1 \mathrm{qt} \ldots \ldots \ldots$ & 2 & 8 to 10 week \\
\hline & $2 \mathrm{ft} . .$. & $21 / 2 \mathrm{ft}$. & $1 / 2$ & 1 oz. to 1500 plants... & 30 & 18 to 20 week \\
\hline Early......... & 15 in... & $3 \mathrm{ft} . .$. & $3 \mathrm{i}$ & 5 lbs.... & $7 \mathrm{r}$ & 10 to 12 week \\
\hline Potatoes, Main Crop. .... & $18 \mathrm{in} .$. & $3 \mathrm{ft} . .$. & 3 in... & 4 lbs... & 10 bu... & 14 to 16 week \\
\hline Sweet.......... & $11 / 2 \mathrm{ft} . \ldots$ & $3 \mathrm{ft} .$. & & & 9680 plants. . & 18 to 20 week \\
\hline & $8 \mathrm{ft} . \ldots$ & $8 \mathrm{f}$ & & $1 / 2$ oz.... & ......... & 12 to 14 week \\
\hline $\mathrm{Ra}$ & $1 \mathrm{in.}$. & 1 & & $1 \mathrm{oz} . .$. & ... & 3 to 4 week \\
\hline mmer...... & 2 in... & $1 \mathrm{ft} . .$. & $1 / 2$ in... & 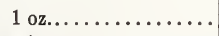 & $\ldots$ & 5 to 6 week \\
\hline Winter....... & 4 in.... & $11 / 2 \mathrm{ft}$. & $1 / 2$ in... & $3 / 4 \mathrm{oz} \ldots$ & $10 \mathrm{lbs} . . . \ldots$ & 7 to 8 week \\
\hline$b \ldots \ldots \ldots \ldots$ & $3 \mathrm{ft} .$. & $3 \mathrm{ft} . \ldots$ & $3 / 4$ in & $3 / 4$ oz... & 4840 roots... & 4 to 6 weeks \\
\hline ga. & 8 in.... & & & $1 / 2$ oz............ & 3 lbs... & 10 to 12 weeks \\
\hline & 6 in... & $11 / 2$ & $1 / 2$ & 1 oz............. & 8 lbs... & 18 to 20 weeks \\
\hline Wr & 3 in.. & $1 \mathrm{ft} . .$. & $1 / 2$ in... & 1 oz............. & 20 lbs... & 8 to 10 week \\
\hline New Zealand & $11 / 2 \mathrm{ft}$. . & $3 \mathrm{ft} . .$. & 1 in.... & $1 / 4 \mathrm{oz} \ldots$ & 3 lbs.... & 10 to 12 week \\
\hline Bush.... & $4 \mathrm{ft} . .$. & $4 \mathrm{ft}$. & 1 & $1 \mathrm{oz} . .$. & 3 lbs... & 7 to 8 week \\
\hline Vine. . & $8 \mathrm{ft} . .$. & $8 \mathrm{ft} . .$. & 1 & $1 \mathrm{oz} .$. & $3 \mathrm{lbs} . .$. & 10 to 12 week \\
\hline hard.. & 6 in..... & $11 / 2 \mathrm{ft} . .$. & & 1 oz................. & 4 lbs... & 7 to 8 weeks \\
\hline Tom & $31 / 2 \mathrm{ft}$. & $31 / 2 \mathrm{ft} .$. & $1 / 2$ in... & $1 \mathrm{oz}$. to 3000 plants... & $2 \mathrm{oz} . .$. & 16 to 18 week \\
\hline Early... & 4 in.... & $11 / 2 \mathrm{ft} .$. & $1 / 2$ in... & $3 / 4 \mathrm{oz}$ & 3 lbs.. & 8 to 10 week \\
\hline Turnip, Late............ & 6 in... & $11 / 2 \mathrm{ft} . \ldots$ & $1 / 2$ in.... & $1 / 2$ oz.............. & 2 lbs......... & 10 to 12 week \\
\hline
\end{tabular}




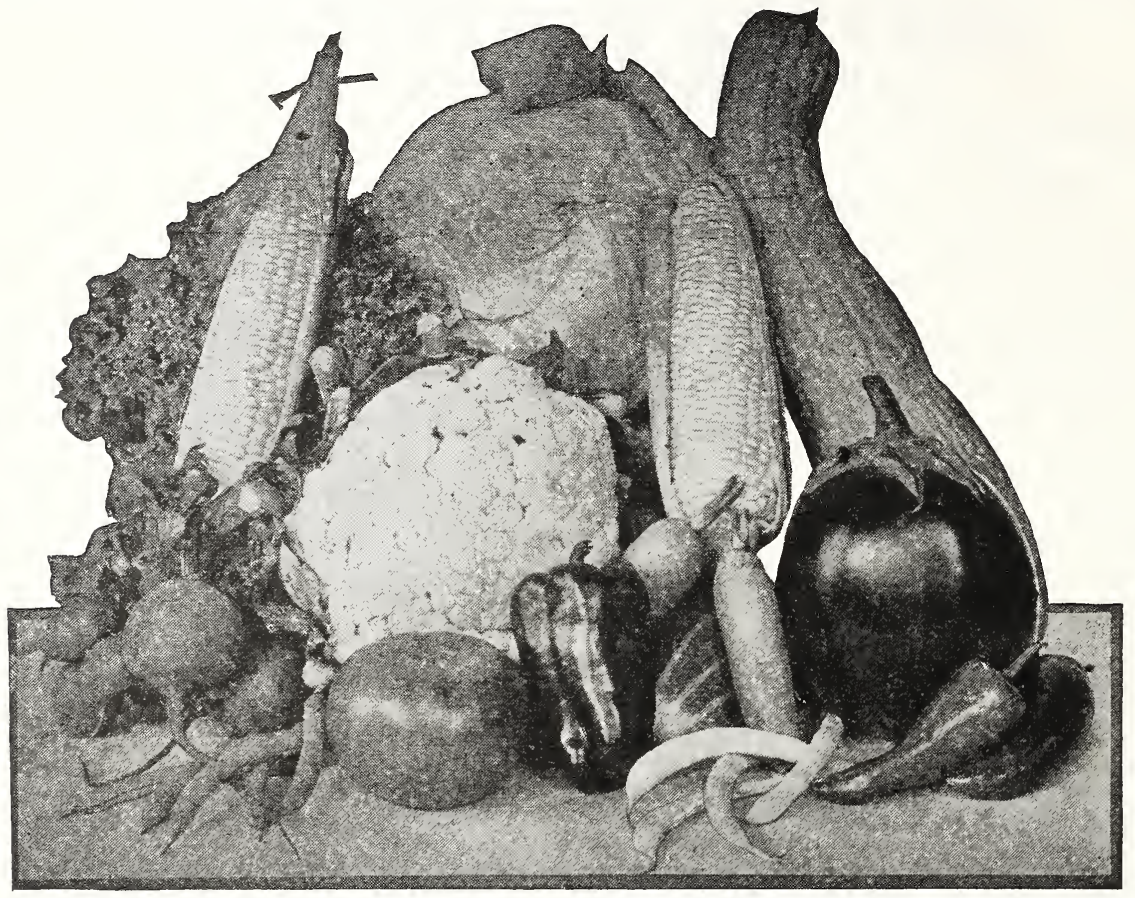

\section{BUIST'S VEGETABLE SEEDS}

\section{General Descriptive List ARTICHOKE}

Large Green Globe-The heads only of this vegetable are used. Sow early in Spring in rows 3 inches apart. When one year old transplant to 2 feet apart each way. Pkt., 10c.; oz., 75c.; $1 / 4$ lb., $\$ 2.50$.

\section{ASPARAGUS}

Sow early in Spring 2 inches deep in rows 18 inches apart. When one or two years old transplant into permanent bed, in furrows 4 to 5 feet apart and 2 feet between the plants. Deep loamy soil, thoroughly cultivated and heavily manured, is required for permanent bed.

Giant Argenteuil-Immensely popular with the largest truckers; very early and unexcelled for size and productiveness. Pkt., 5c.; oz., 10c.; $1 / 4$ lb., 25c.; lb., 75c.

Palmetto-A very early and prolific variety, producing an abundance of large, deep green shoots delicious in flavor. Pkt., 5c.; Oz., 10c.; I/4 1b., 25c.; lb., 75c.

Asparagus Roots-Strong roots of above ready after March 1st, 90c. per 50; $\$ 1.75$ per 100 , postpaid; by express or freight, $\$ 1.50$ per $100 ; \$ 10.00$ per 1000 .

Washington-This variety is the result of careful breeding to produce a rust-resisting vigorous strain of Giant Asparagus. Plants produce long, thick, heavy stalks of a dark green color, delicious in flavor. Pkt., 10c.; oz., 15c.; I/4 lb., 40c.; lb., \$1.25.

Mary Washington-The highest type of the rust-resisting Asparagus. It is earlier, larger and longer than the original Washington and quite as resistant. Pkt., 10c.; Oz., 15c.; I/4 lb., 50c.; lb., \$1.75.

Roots-Strong roots of the Washington varieties, $\$ 1.25$ per $50 ; \$ 2.00$ per 100 , postpaid; by express or freight, $\$ 1.75$ per $100 ; \$ 12.00$ per 1000 .

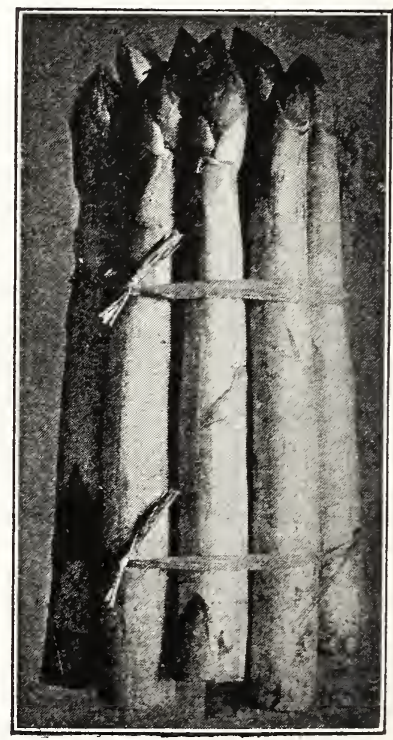

Giant Argenteuil Asparagus 


\section{BEANS (Dwarf or Bush)}

\section{GREEN PODDED VARIETIES}

Plant when the ground is warm, as beans are very sensitive to cold and wet weather. For a succession, plant in rows 2 feet apart every two weeks until August, covering the seed about $11 / 2$ inches, and thin the plants to stand about 4 inches apart in the rows. Give frequent but shallow cultivation to blossoming time, but only when the plants are dry. If cultivated when wet, they will be damaged by rust. One pound will sow 50 feet of drill, $11 / 2$ bushels per acre.

\section{BUIST'S PROLIFIC STRINGLESS GREEN POD}

A superior stringless variety, produc. ing large handsome green pods throughout a long season, some of which measure fully 6 inches in length. The plants are very productive, bearing profusely; the pods are of a beautiful green color, round, tender and brittle, of the finest flavor; quite fleshy and entirely stringless. A desirable variety for either the home or market garden. Pkt., 10c; lb., 40c; 2 lbs., 75c; 10 lbs., $\$ 3.50$.

EXTRA EARLY RED VALENTINE

A very early standard variety. It is a wonderful producer and a fine shipper. Very hardy and will germinate in cold ground when other sorts would rot. Pods round, $41 / 2$ inches long, very fleshy and tender. It is resistant to disease and will thrive on any kind of soil. Pkt., 10c; lb., 30c; 2 lbs., 55c; 10 lbs., \$2.50.

\section{BLACK VALENTINE}

$A$ very popular market variety because of its hardiness and blight resist. ing qualities. The pods are medium dark green and about 6 inches long; they grow in clusters perfectly straight and round. It will withstand cold, wet weather to remarkable degree. Highly recommended for late planting as well as first early. Pkt., 10c; lb., 30c; 2 lbs., 60c; 10 lbs., \$2.70.

\section{FULL MEASURE}

The pods are long, meaty and tender, with. out strings, and remain fit for use for many days after maturity. Very prolific and of ex. cellent quality. Pkt., 10c; lb., 45c; 2 lbs., 80c; 10 lbs., \$3.75.

\section{LOW'S CHAMPION, OR DWARF RED CRANBERRY}

Pods are 5 inches long, flat, straight and almost stringless. It is very prolific and a vigorous grower. Pkt., 10c; lb., 30c; 2 lbs., $60 \mathrm{c} ; 10 \mathrm{lbs} ., \$ 2.70$.

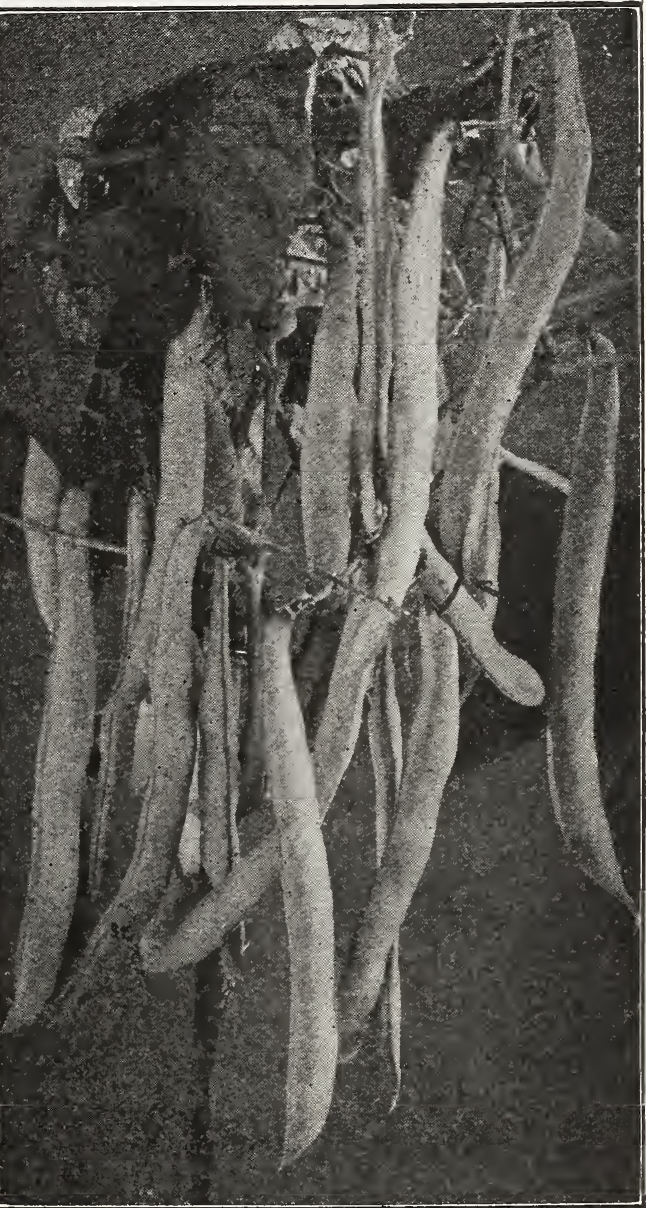

Buist's Prolific Stringless Green Pod Beans

\section{GIANT STRINGLESS GREEN POD}

A very desirable variety of the stringless class; quite early, producing large green pods measuring 5 to 6 inches in length; perfectly round, brittle, very fleshy and entirely string. less. They mature a few days later than the Stringless Green Pod. An excellent sort for both early and late planting. Pkt., 10c; lb., 40c; 2 lbs., 75c; 10 lbs., \$3.50.

\section{LONGFELLOW}

An extra early variety of finest quality, producing round, straight pods 6 inches long, solid, fleshy and exceedingly tender. The plants are of robust compact growth, unex. celled in bearing qualities. Pkt., 10c; lb., 30c; 2 lbs., 60c; 10 lbs., $\$ 2.70$.

IF BEANS, PEAS or CORN are ordered by Mail, please add postage to cover COST of PARCEL POST. See zone rate on inside back cover page. 


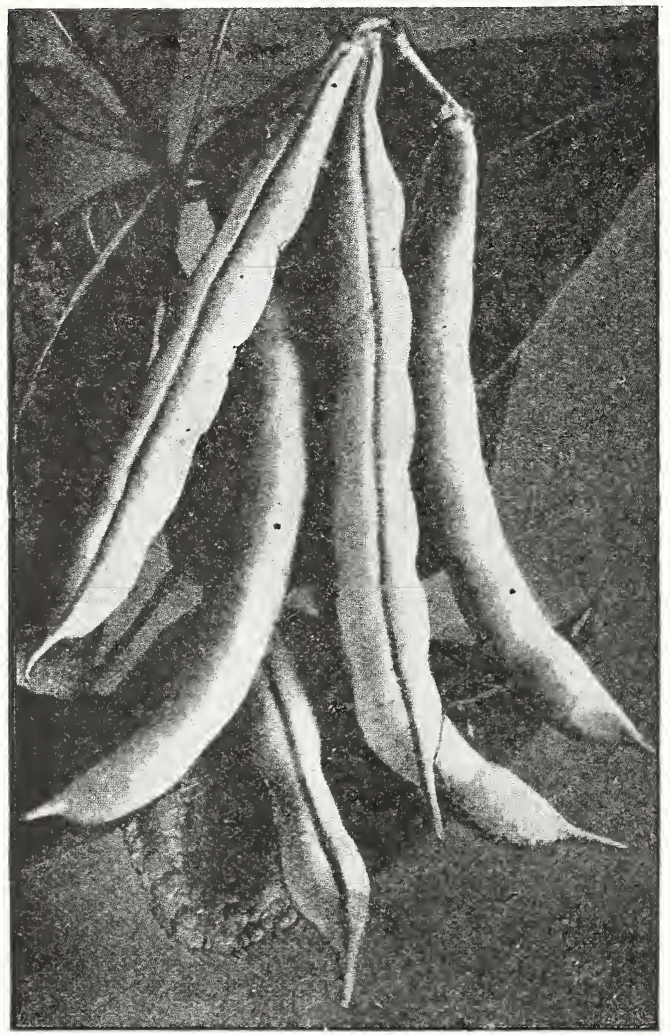

Stringless Green Pod Beans

Stringless Green Pod-One of the finest of the stringless varieties, and now ranking with the famous Valentine in popularity and value. It cannot be recommended too highly to either the market gardener, private grower or canner; it is ready for the table as soon as the Valentine, and the pods, being round and full, are very fleshy and succulent; they are absolutely stringless. The pods are larger and better flavored than Valentine and remain tender longer. Pkt., 10c.; lb., 35c.; 2 lbs., 70c.; 10 lbs., \$3.25.

Bountiful-This plant is very handsome and of sturdy growth, being practically immune to rust and mildew. It is very hardy, early and prolific and continues in bearing for several weeks. The pods are of immense size, rich green, thick, broad, extra long, solid, meaty, rich, tender and entirely stringless. Pkt., 10c; lb., 40c.; 2 lbs., 75 c.; 10 lbs., \$3.50.

Extra Early Refugee-Very popular, especially in the South, because of its earliness; pods are round, of bright green color; very productive and always certain of producing a crop even in unfavorable seasons. Pkt., 10c.; 1b., 30c.; 2 lbs., 55c.; 10 lbs., $\$ 2.50$.

Late Refugee or Thousand-to-One -A very excellent variety, very similar to the Valentine when green, though a stronger grower and is extensively used for shipping, canning and pickling. Pkt., 10c.; lb., 30c.; 2 lbs., 55c.; 10 lbs., $\$ 2.50$.

Tennessee Green Pod-Very popular in some sections of the South. Pods very long, flat, irregular in shape, bright, but rather dark green and of excellent quality. Pkt., 10c.; lb., 30c.; 2 lbs., 60c.; 10 lbs., $\$ 2.60$.

French's Horticultural-Vines grow very erect and throw out some runners. Pods long, splashed with crimson. Pkt., 10c.; lb., 35c.; 2 lbs., 65c.; 10 lbs., $\$ 3.00$.

Dwarf Horticultural (Italian Beans)-A vigorous grower with large green pods, splashed with carmine. Excellent either as snaps in the green state, shelled green or dry. Pkt., 10c.; lb., 30c.; 2 lbs., 60c.; 10 lbs., $\$ 2.75$.

\section{SHELL BEANS FOR WINTER USE}

Large White Marrow-The standard variety for soup beans. Vines large, slender, spreading with short runners and small leaves. Very prolific cooking dry and mealy. Pkt., 10c.; 1b., 30c.; 2 lbs., 55c.; 10 lbs., $\$ 2.50$.

White Navy or Boston Pea Bean-This variety will outyield all others. The beans are small, oval, white and of superior quality for use as baked beans. Pkt., 10c.; lb., 25c.; 2 lbs., 50c.; 10 lbs., \$2.25.

White Kidney-Excellent either green or ripe as a shell bean. Seed large, white, kidney shaped. Pkt., 10c.; 1b., 30c.; 2 lbs., 55c.; 10 lbs., $\$ 2.50$.

Red Kidney-For same use as the White Kidney. Pkt., 10c.; 1b., 30c.; 2 lbs., 55c.; 10 lbs., $\$ 2.50$.

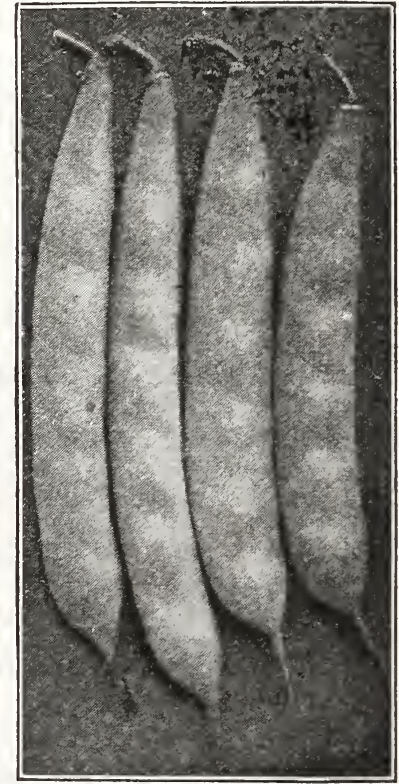

Bountiful Beans 


\section{Wax Podded Bush Beans}

\section{RUST PROOF GOLDEN WAX}

No variety of Snap Bean ever introduced has given the satisfaction and profit equal to the Rust Proof Golden Wax. Its pods are fleshy, of a beautiful golden waxy color, of a large size, quite productive, and of luscious flavor. Pkt., 10c; lb., 35c; 2 lbs., 65c; 10 lbs., \$3.00.

\section{ROUND POD KIDNEY WAX}

Long, round, yellow pods; stringless; an exceedingly desirable variety, especially for the table and home market. Growth dwarf, spreading; very productive. Pkt., 10c; lb., 35c; 2 lbs., 70c; 10 lbs., \$3.25.

\section{DWARF PROLIFIC BLACK WAX}

A great favorite, both with market gardeners and private planters, on account of the fine quality and early maturity of its tender, yellow, waxy pods. The pods are about 5 inches long, fleshy, crisp and stringless. Pkt., 10c; lb., 35c; 2 lbs., 65c; 10 lbs., \$3.00.

\section{WARDWELL'S KIDNEY WAX}

One of the most profitable varieties for the market gardener; especially popular in the South; long, straight, cream yellow pods of excellent quality; maturing a little later than Golden Wax. This splendid variety is now a popular favorite every where, not only for shipping, but for the local market and the home. Pkt., 10c; lb., 35c; 2 lbs., 65c; 10 lbs., $\$ 3.00$.

\section{DAVIS WAX}

A very hardy and productive variety; the vine is rust. less and very vigorous, bearing its pods near the center in clusters. Pods 7 inches long, straight, very uniform, waxy white, brittle, crisp and tender. We recommend them to shippers and market gardeners as the best market wax bean. Pkt., 10c; lb., 35c; 2 lbs., 65c; 10 lbs., \$3.00.

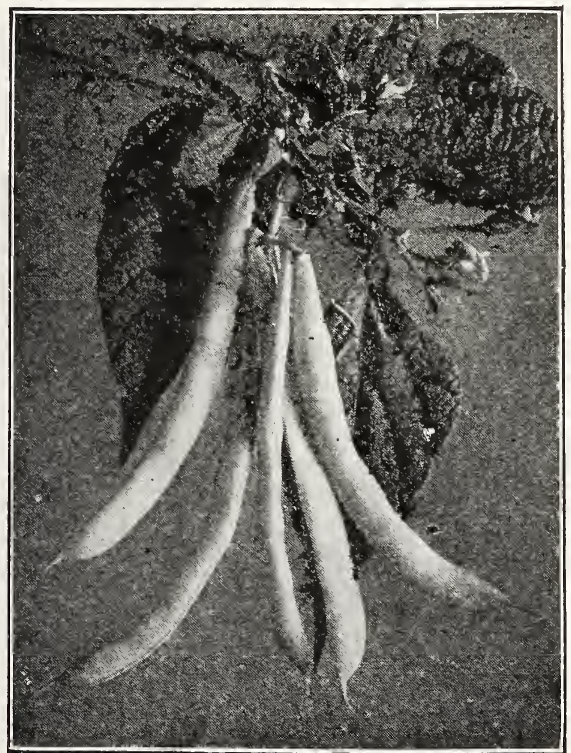

Brittle Wax Beans

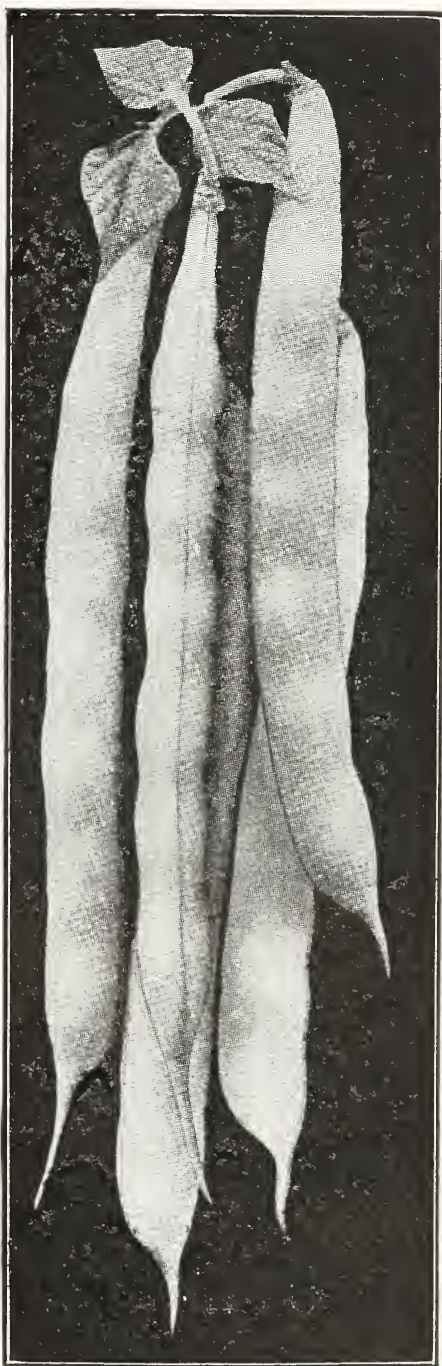

Best of All Wax Beans

"BEST OF ALL" STRINGLESS WAX

Very early, the pods of which are produced in great abundance and will average 6 inches in length; exceedingly brittle and of a delicate flavor. Entirely free from rust and blight and will withstand cold, wet weather to a remark. able degree. Highly recommended to ship. pers and market gardeners. Pkt., 10c; lb., 35c; 2 lbs., 70c; 10 lbs., \$3.25.

\section{BRITTLE WAX}

A variety of unusual merit for market or home gardens. Very early, the pods of which are produced in great profusion and will average 6 inches in length. Pkt., 10c; lb., 35c; 2 lbs., 70c; 10 lbs., \$3.25.

IF BEANS are ordered by mail, postage must be added to cover COST of PARCEL POST. See zone rate on inside back cover page. 


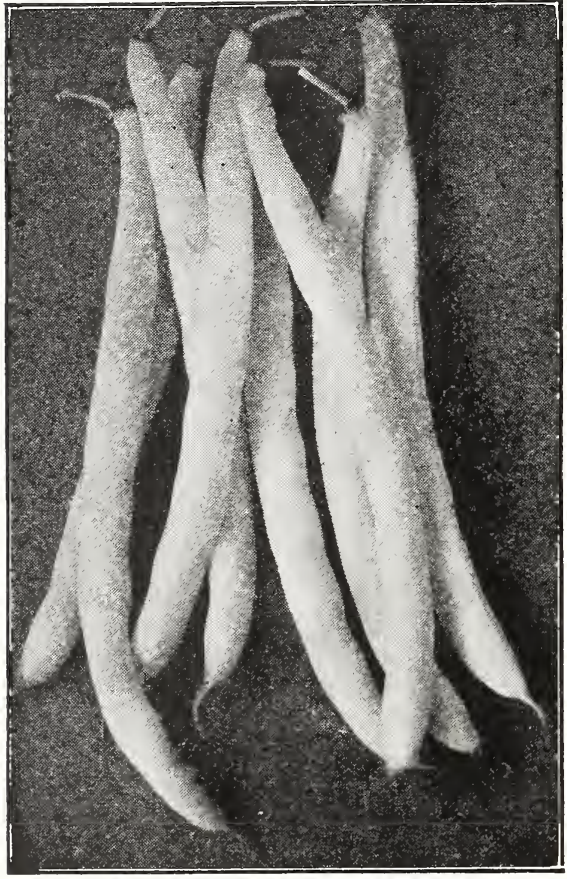

Unrivaled Wax Beans

\section{UNRIVALED WAX BEANS}

Pods are larger than Golden Wax and a little lighter in color, are semi-flat, slim, but fleshy. A vigorous grower and very produc. tive, entirely stringless, exceedingly tender and of a very rich flavor. It is the earliest of all wax beans. Pkt., 10c; lb., 35c; 2 lbs., 70c; 10 lbs., \$3.25.

\section{PENCIL POD WAX}

The best black seeded Wax Bean for home use or market. Very early and productive, pods large and round, 5 to 6 inches long, strictly stringless, very brittle and of excellent quality. Pkt., 10c; lb., 35c; 2 lbs., 65c; 10 lbs., \$3.00.

\section{CURRIE'S RUST PROOF}

The pods are light yellow, similar in shape to the Golden Wax, but longer; and nearly as rust proof as any good Wax Bean could possibly be. The plants are hardy and productive. Grown largely by market gardeners because of its earliness and productiveness. Pkt., 10c; lb., 35c; 2 lbs., 65c; 10 lbs., \$3.00.

\section{CRYSTAL WHITE WAX}

A distinct variety, sometimes called Silver Wax Beans. Color of pods, greenish white with silvery shade. Stringless, crisp, tender and of rich flavor. The pods develop quickly, but mature slowly and remain in condition for table use longer than any other variety. Pkt., 10c; lb., 40c: 2 lbs., 75c; 10 lbs., \$3.50.

\section{SURE CROP STRINGLESS WAX}

This variety is well adapted for market garden purposes because of its vigorous growth, productiveness and hardiness. Pods are rich yellow, 6 to 7 inches long, entirely stringless at all stages of development. Pkt., 10c; lb., 35c; 2 lbs., 65c; 10 lbs., \$3.00.

\section{NEW STRINGLESS KIDNEY WAX}

A long.podded wax bean perfectly string. less and of the finest eating quality. The fleshy pods, flattened in form 6 to 7 inches long, are remarkable for their meatiness, fine flavor, brittleness and freedom from strings. Pkt., 10c; lb., 40c; 2 lbs., 75c; 10 lbs., \$3.50.

\section{CRACKER JACK OR WEBBER WAX}

Very early and productive, free from blight and rust proof. The pods are flat, very fleshy and entirely stringless. The plants are strong growing and bear their pods well above the ground. Market gardeners will find this an cxcellent variety to grow for shipping. Pkt., 10c; lb., 35c; 2 lbs., 65c; 10 lbs., \$3.00.

\section{HODSON WAX}

The pods are straight and average about 7 inches in length; color, clear light yellow. Vines are very vigorous and well filled with pods that are entirely free from rust and blight. Pkt., 10c; lb., 35c; 2 lbs., 65c; 10 lbs., $\$ 3.00$.

\section{REFUGEE WAX}

A superior bean for home use. Pods are long, round and yellow; are thick meated, perfectly stringless and of excellent flavor. Dry beans are mottled dark drab. Pkt., 10c; lb., 35c; 2 lbs., 65c; 10 lbs., \$3.00.

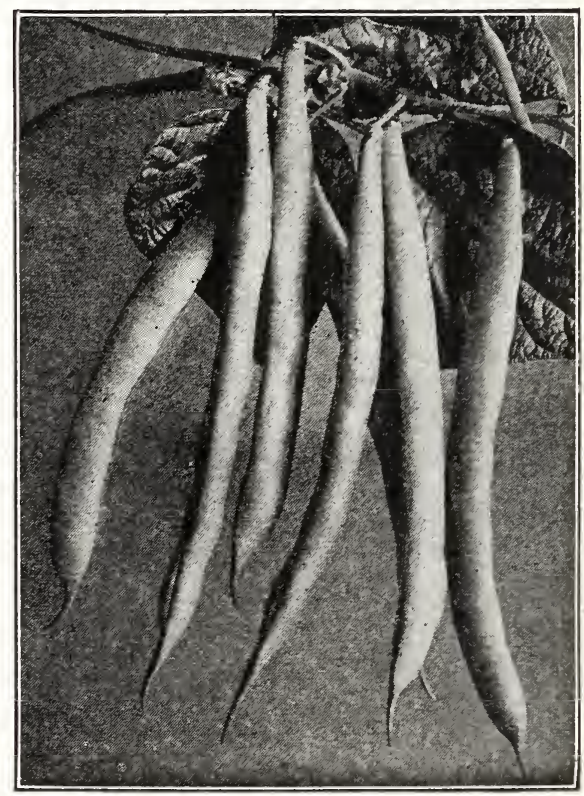

Pencil Pod Wax Beans 


\section{DWARF LIMA BEANS}

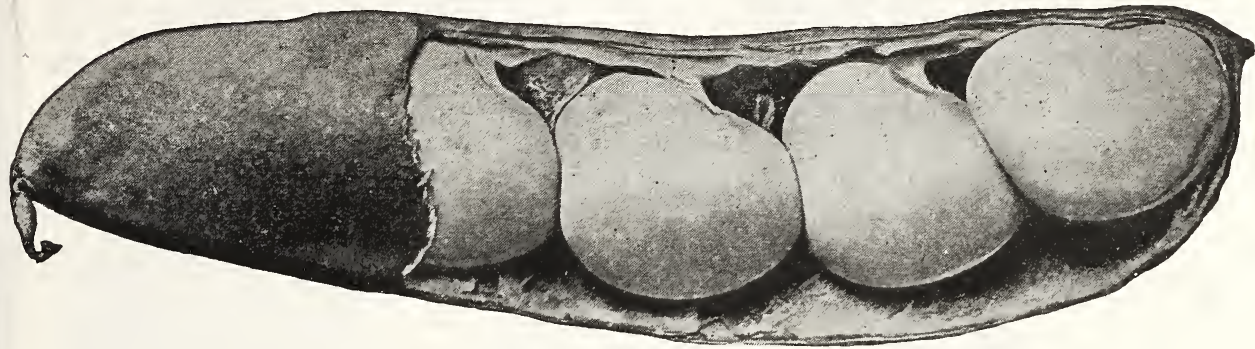

Fordhook Bush Lima Bean

Fordhook Bush Lima-The most popular type of Bush Lima Beans in cultivation. Plants are vigorous and erect, bearing well above the ground. The pods, which are produced in clusters, contain four to five large, thick beans, which are of a delicious and distinct flavor. Matures early and is a continuous bearer. Pkt., 10c.; lb., 45c.; 2 lbs., 85c.; 10 lbs., $\$ 4.00$.

Burpee's Improved Bush Lima-An improvement over the popular Burpee's Bush, producing both pods and beans of a much larger size. Pkt., 10c.; lb., 35c.; 2 lbs., 65c.; 10 lbs., $\$ 3.00$.

Burpee's Dwarf, or Bush Lima-Produces beans as large as the Pole Lima; the plants grow about 20 inches high, of stout growth and erect, yet branching into a bush from 2 to 3 feet in diameter. Pkt., 10c.; lb., 30c.; 2 lbs., 60c.; 10 lbs., $\$ 2.70$.

Wood's Prolific Bush Lima (Butter Bean) -An improvement on the Henderson. The Pods are larger and the beans of excellent flavor. Pkt., 10c.; 1b., 30c.; 2 lbs., 60c.; 10 lbs., $\$ 2.50$.
Buist's Superba Giant Podded Bush Lima -The largest podded and most prolific Bush Lima Bean yet produced. The plants grow upright, about 2 feet in height, requiring neither pole nor stakes; the shelled beans, either green or dry, are of immense size and superb quality. A continuous bearer from July until frost, possessing all good qualities of pole lima. We consider this variety a decided acquisition and should have a place in every garden. Pkt., 10c.; lb., $35 \mathrm{c}$.; 2 lbs., $65 \mathrm{c}$.; 10 lbs., $\$ 3.00$.

Henderson Bush Lima-The original Bush Lima Bean, known through the South as the "Dwarf Butter Bean." Earlier than all other sorts and very productive; a sure cropper and continues producing until frost. Grown extensively for canning, owing to the small size of the beans, which have the appearance of being young even when old. Pkt., 10c.; 1b., 30c.; 2 lbs., 60c.; 10 lbs., \$2.50.

Jackson Wonder Bush Lima-Very early, seed of brownish color. Pkt., 10c.; lb., 30c.; 2 lbs., 55c.; 10 lbs., $\$ 2.30$.

\section{POLE OR CORNFIELD SNAP BEANS}

London Horticultural-The finest baking Bean; pods 6 inches in length; good either as a snap or for shelling. Very hardy and productive. Pkt., 10c.; lb., 30c.; 2 lbs., 55c.; 10 lbs., $\$ 2.30$.

Early Golden Cluster Wax Pole-Very early; fine quality; stringless; very productive; remains tender long after pods are developed. Good both for snap and shelling. Pkt., 10c.; 1b., 35c.; 2 lbs., 65 c.; 10 lbs., $\$ 3.00$.

Texas Pole-The plants are vigorous climbers; pods borne profusely in clusters. They average 7 to 9 inches long; are of attractive green color, round and very brittle when young. If the beans are picked as they mature the vines will bear until killed by frost. Pkt., 10c.; 1b., 30c.; 2 lbs., 55c.; 10 lbs., \$2.40.
Buist's Southern Cornfield-Pods 6 to 7 inches long, borne in clusters; good shipper and an excellent snap; seeds white; good for baking. Pkt., 10c.; lb., 30c.; 2 lbs., 50c.; 10 lbs., \$2.30.

Monster Podded Southern Prolific-An improved strain of the old Southern Prolific; much larger and of better quality than that well-known varietywhich we have now discarded. Pkt., 10c.; 1b., 30c.; 2 lbs., 60c.; 10 lbs., $\$ 2.50$.

Cut Short, or Corn Field (Red Speckled) -An old popular variety, one of the best for planting among corn. Vines are not quite so heavy as Kentucky Wonder, and will produce a good crop without the use of poles. The pods are of good quality. Pkt., 10c.; lb., 30c.; 2 lbs., 50c.; 10 lbs., \$2.30. 


\section{POLE or CORNFIELD SNAP BEANS}

Kentucky Wonder, or Improved Old Homestead-Best and earliest of the green-podded running Beans; enormously productive, the pods hanging in great clusters from top to bottom of pole; silvery-green and entirely stringless; deliciously tender and melting; highly recommended . Pkt., 10c.; lb., 30c.; 2 lbs., 60c.; 10 lbs., $\$ 2.50$.

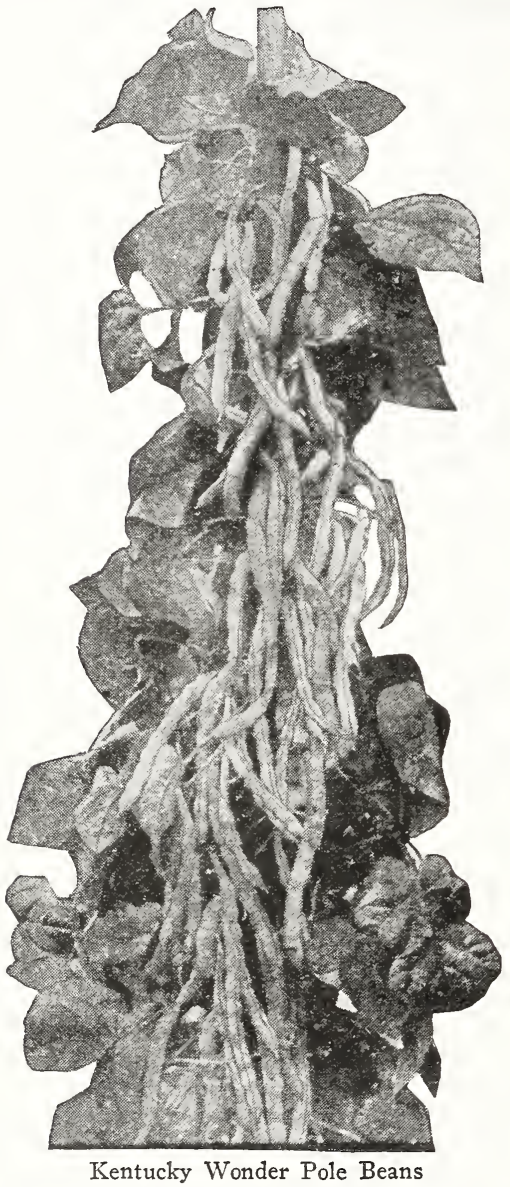

White Seeded Kentucky Wonder-A new pole variety of great merit; bears long, brittle, stringless pods, very meaty and of excellent flavor and quality. The pods are uniformly large, 6 to 8 inches long, moderately slender, crease back, almost straight and very dark green. The dry beans are pearly white, and splendid for baking. Pkt., 10c.; 1b., 30c.; 2 lbs., 60c.; 10 lbs., $\$ 2.50$.
Big Chief-This new green podded Pole Bean is a marvel for continuous productiveness. The pods are straight and decidedly double-barreled and will average eight to ten inches in length; they are exceptionally brittle, stringless, tender and delicious. Vines continue to bear throughout the season. Pkt., 10c.; lb., 40c.; 2 lbs., 70c.; 10 lbs., \$3.25.

"Nancy Davis" Cornfield Beans-For many years we have tried to secure a cornfield Bean that would not become tough or shucky, and in introducing the "Nancy Davis," believe that we have at last secured a sort that will give perfect satisfaction. Vines medium size, vigorous and productive, continue to bear late in the Fall; pods 5 to 7 inches long, round and fleshy. Pkt., 10c.; lb., 30c.; 2 lbs., 55c.; 10 lbs., $\$ 2.30$.

Southern White Crease Back-(Mobile Pole). Handsome green pods 6 to 7 inches long, produced in clusters; meaty; almost stringless; splendid shipper. Pkt., 10c.; lb., 30c.; 2 lbs., 50c.; 10 lbs., \$2.30.

Kentucky Wonder Wax-Vigorous wax podded bean similar in habit of growth to green podded Kentucky Wonder and bears as early. Pods beautiful golden yellow, free from strings; fleshy and of excellent quality. Pkt., 10c.; lb., 35c.; 2 lbs., 65 c.; 10 lbs., $\$ 3.00$.

McCaslan Pole-An early maturing green-podded, white-seeded pole variety. Pods are large, deep green in color; very meaty; stringless, and continue to bear throughout the season if kept closely picked. Pkt., 10c.; lb., 35c.; 2 lbs., 65c.; 10 lbs., $\$ 3.00$.

Brown Sickle-A large, green-podded variety, very productive; the pods are curved. If gathered as they mature, they will continue to bear throughout the season. Pkt., 10c.; 1b., 30c.; 2 lbs., 60 c.; 10 lbs., $\$ 2.50$.

Lazy Wife Pole-A remarkable variety, not only for its great productiveness, but also for its fine quality. The pods are produced in great clusters, which makes the picking of them an easy task. They continue bearing throughout the season. The pods are broad, thick, fleshy, and from 4 to 6 inches long, and when young entirely stringless and of a rich buttery flavor. Pkt., 10c.; lb., 30c.; 2 lbs., 60c.; 10 lbs., $\$ 2.50$.

Scarlet Runner-A popular English pole Bean, ornamental and useful. The vine is graceful, flowers are of a brilliant scarlet and the beans are of excellent quality, either when shelled or in a dry state. Pkt., 10c.; lb., 40c.; 2 lbs., 75c.; 10 lbs., \$3.25. 


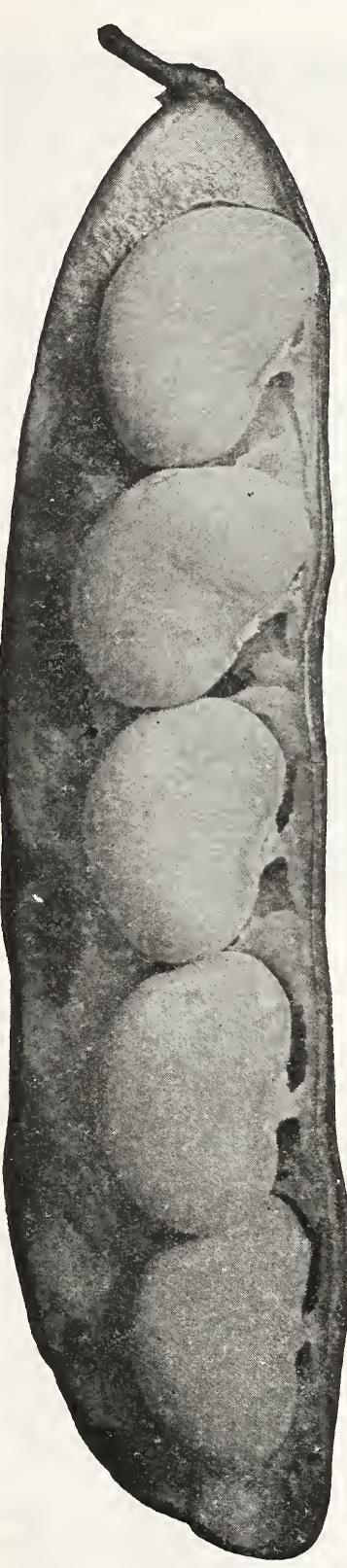

Buist's Mammoth Podded Ideal Pole Lima Beans

\section{POLE LIMA BEANS}

Culture.-Lima Beans require warm and rich loamy soil, the germ is very delicate, and sometimes the first planting is destroyed by cold and wet weather; to insure against this the beans can be sprouted in small flower pots, or by placing them on sods of earth, placed in a frame, covered lightly with soil, and planting them out when the weather becomes warm; this will increase their earliness. Plant 4 to 6 beans around each pole and thin out to 3 plants to a pole. One quart will plant 100 hills.

Buist's Mammoth Podded Ideal Lima-The most valuable Lima Bean yet introduced; vines vigorous and productive, bearing large clusters of broad pods, 6 to 8 in a bunch, the pods being 6 to 8 inches long, containing five to seven beans of gigantic size. The vines are remarkably productive, the pods at the bottom of the plant maturing early in the season, those at the top coming in before frost; the beans are easily shelled and of handsome appearance. The gigantic size makes it a valuable bean for home or market garden. Pkt., 10c.; lb., 35c.; 2 lbs., 65c.; 10 lbs., \$3.00.

Salem Mammoth Lima-Remarkable for the large size of both pods and beans, as well as for its earliness. The beans, when dry, are of a beautiful light green color and almost twice the size of the ordinary Lima. Pkt., 10c.; 1b., 30c.; 2 lbs., 60c.; 10 lbst, $\$ 2.75$.

Carpinteria Green Seeded Lima-The beans of this new variety have a greenish tint, retaining their color when cooked. Very productive, with strong, vigorous vines having many branches, producing numerous pods, containing four large beans which are broad and plump. Pkt., 10c.; 1b., 30c.; 2 lbs., 60c.; 10 lbs., \$2.75.

Extra Early Jersey Lima-Ready for the market from ten days to two weeks earlier than any other variety, frequently ready for picking by the middle of July; the beans and pods are smaller than those of the common Lima, but of a more delicate flavor. Pkt., 10c.; 1b., 30c.; 2 lbs., 60c.; 10 lbs., $\$ 2.75$.

Dreer's Improved, or Challenger Lima-Also known as the Potato Lima. Entirely distinct, producing thick compressed-looking beans in their pods, which are of a delicious and distinct flavor; very productive. Pkt., 10c.; lb., 35c.; 2 lbs., 65c.; 10 lbs., $\$ 3.00$.

Early Leviathan Pole Lima-The best of all early sorts, equal to the main crop varieties in productiveness; vines very tall and showy; pods long and borne in clusters, beans are large and white. Pkt., 10c.; lb., 30c.; 2 lbs., 60c.; 10 lbs., $\$ 2.75$.

King of the Garden Lima-A very popular variety, producing very large pods and beans of a large size when in a green state. It is of a strong growth, exceedingly productive, and frequently producing five or six beans to the pod; highly recommended. Pkt., 10c.; 1b., 30c.; 2 lbs., 60c. 10 lbs., $\$ 2.75$.

Ford's Mammoth Podded Lima-Pods prodigious in size, containing from five to eight mammoth beans; quality unsurpassed, excels any other variety for productiveness. Pkt., 10c.; lb., 30c.; 2 lbs., 60c.; 10 lbs., \$2.75.

Florida Butter-Very early and bears profusely throughout the season. Seeds of the Carolina or Sieva size, but are speckled white and brownish red. A favorite sort in some sections of the South. Pkt., 10c.; lb., 30c.; 2 lbs., 60c.; 10 lbs., \$2.75.

Carolina Sewee, or Sieva-A celebrated variety, known in the South as Pole Butter Beans, where it is cultivated very extensively and preferred to the Lima, produces beans half the size. This variety is a continuous bearer, very early and more prolific than the large Lima sorts. Pkt., 10c.; lb., 30c.; 2 lbs., 60c.; 10 lbs., \$2.75. 


\section{BEETS}

Little skill is necessary for the cultivation of this vegetable. One grand essential for an early crop is to dig or plough deep and manure well, and sow as early in the Spring as the soil will permit of working; draw drills half an inch deep and 18 inches apart; sow the seeds thinly, cover them lightly and rake finely; before raking sow a sprinkling broadcast of Early Radish Seed, as they will be fit for pulling before the Beets are ready for thinning, which will be in about four weeks. As soon as the Beets have formed a few leaves, thin them out to 3 inches apart, allowing the strongest plants to remain. For a Winter crop sow late in Spring or early Summer. Half Long Blood and Buist's Perfect Model Beet; on the approach of frost take up the roots and cut the leaves off to about two inches of the crown, store them in pits secure from frost, or in a cool, dry cellar, covered with earth or sand.

Crosby's Early Egyptian TurnipImproved strain of the famous Early Egyptian, but producing a deeper or thicker root; of fine form, extremely early, deep red color, almost black; flesh sweet, smooth, tender and of exceptionally fine quality; can be depended on for best results when grown either in the garden or under glass; highly recommended as an early market variety. Pkt., 5c.; I/2 oz., 10c.; oz., 15c.; I/4 1b., 30c.; lb., $\$ 1.10$.

Buist's Special Crosby's Egyptian-A very fine selection of the Crosby's Egyptian that will please the most critical. In color and shape it is unsurpassed. The flesh is a dark vermillion red, crisp and tender and of excellent quality. It is a rapid grower, attaining a salable size quicker than any other variety. Pkt., 5c.; I/2 oz., 10c.; Oz., 15c.; I/4 lb., 40c.; lb., \$1.25.

Early Blood Turnip-Is one of the most popular varieties but ten days later than the Crosby's; flesh dark blood-red, very sweet and delicate in flavor, and as a general market variety it is superior to all on account of its rich blood color; it is adapted for either Winter or Summer use. Pkt., 5c.; oz., 10c.; $1 / 4$ lb., 30c.; Ib., $\$ 1.00$.

Extra Early Egyptian-The best variety for forcing. The roots are distinctively flat on bottom and moderately thick; quick to mature, flesh is very dark bloodred. The top is small. Pkt., 5c.; $1 / 2$ oz., 10c.; 1 oz., 15c.; $1 / 4$ lb., 35c.; 1b., \$1.10.

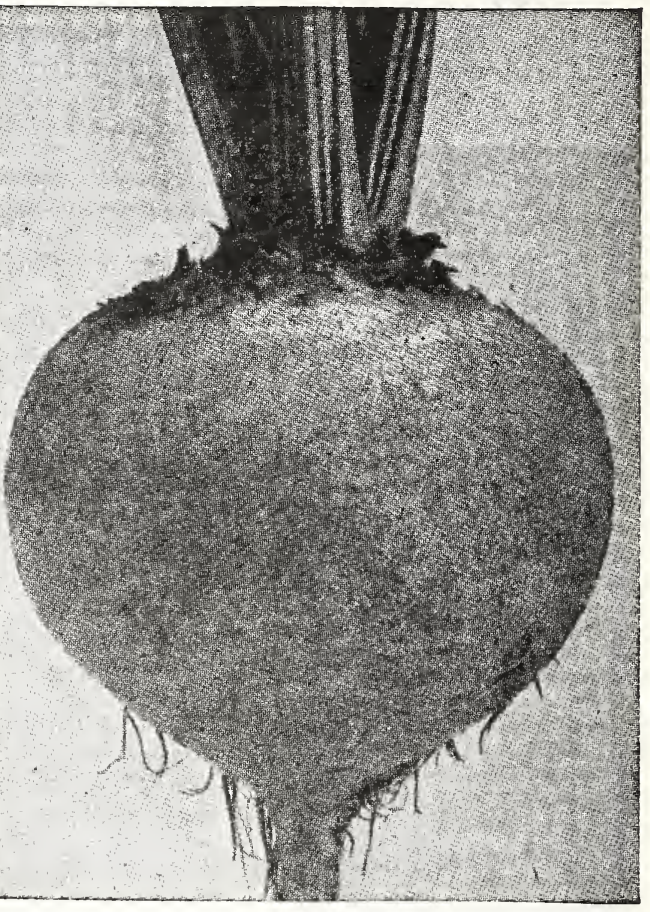

Detroit Dark Red Beet

Detroit Dark Red-This splendid second early variety we highly recommend for market and private gardens. Roots globular, very smooth, with short tops; skin b.lood-red, flesh dark blood-red, sweet, tender and delicious. The tops are small and upright in growth. Fine for market bunching. Pkt., 5c.; $1 / 2$ oz., 10c.; oz., 15c.; I/4 lb., 40c.; lb. \$1.25.

Buist's Extra Early Turnip-This is the earliest of all varieties, is the leading sort grown by our gardeners for Philadelphia market. Unlike other early varieties, is dark red color, perfect form, with short leaves, and a delicate, sweet flavor; it forces well in frames and is the most profitable to grow for early market. Pkt., 5c.; 1/2 Oz., 10c.; oz., 15c.; I/4 lb., 40c.; lb., \$1.25.

Nutting's Early Gem-One of the best and earliest beets for growing either out of doors or under glass. The shape is very desirable, color dark, quality unsurpassed; the foliage is scant. An excellent sort for market gardeners. Pkt., 5c.; $1 / 2$ Oz., 10c.; Oz., 15c.; $1 / 4$ lb., 40c.; 1b., $\$ 1.25$.

Extra Early Turnip, or Bassano-This variety when young is very sweet and tender. The roots attain a large size, are light red in color, flesh is white, circled with bright pink. Pkt., 5c.; oz., 10c.; $1 / 4$ lb., 30c.; 1b., \$1.00. 
Buist's Perfect Model-This new variety is an improved strain of our "Shull's Model Beet," introduced by us in 1886 , and by careful comparison has proven to be the best for Market Gardeners; its uniformity in shape, medium size and deep red color makes it a very desirable market beet. The tops are small and its growth upright; for bunching and shipping it has no equal. For the home-garden it is especially desirable on account of its exquisite quality, being very sweet and fine grained; is a good keeper and may be used all Winter; the deep, rich color makes it a very desirable sort for canners. Pkt., 10c.; oz., 15c.; 1/4 lb., 50 c.; lb., $\$ 1.50$.

Early Wonder-One of the earliest beets in cultivation. The flesh is a rich dark red color, tender, crisp and deliciously sweet. It makes an attractive bunch beet and may be sown early or late. For the Market Gardener this is a splendid variety. Pkt., 10c.; Oz., 15c.; $1 / 4$ lb., 40c.; lb., \$1.25.

Early Eclipse-This we regard as one of the most valuable varieties for either market or private gardens; is remarkable for its very rapid growth, perfection of form, which is globular, of beautiful crimson flesh, and for its dwarf foliage; the roots are of a bright, glossy red, very fine grained and of delicious flavor. Pkt., 5c.; Oz., 10c.; $1 / 4$ lb., 30c.; 1b., \$1.00.

Edmand's Early Blood Turnip-A handsome, clean turnip-shaped Blood Beet. The skin and flesh are dark red and exceedingly sweet and tender; the tops are small, allowing them to be grown close together. Pkt., 5c.; oz., 10c.; $1 / 4$ lb., 30c.; lb., $\$ 1.00$.

Crimson Globe-A second early variety, of a beautiful globe form, medium in size and perfectly smooth. Flesh and skin very dark, tender and of delicious flavor at all stages of its growth. Pkt., 5c.; $1 / 2$ Oz., 10c.; Oz., 15c.; $1 / 4$ lb., 40c.; lb., \$1.25.

Lentz Extra Early Red Turnip-This variety is of a very rapid growth forming marketable-sized roots in six weeks from time of sowing; of a beautiful form, very sweet and of delicious flavor, retaining its bright blood color when cooked. Pkt., 5c.; $1 / 2$ Oz., 10c.; Oz., 15c.; $1 / 4$ lb., 40c.; lb., \$1.25.

Long Dark Blood-A standard late variety of very good quality, which keeps well through the Winter. Pkt., 5c.; oz., 10c.; $1 / 4$ lb., 30c.; 1b., 85c.

Buist's Scarlet Perfection-One of the most beautiful varieties grown, of halflong shape, dark-blood color, with a deep, rich crimson foliage; a very desirable variety for both Fall and Winter use. Pkt. 5c.; $1 / 2$ Oz., 10c.; Oz., 15c.; $1 / 4$ lb., 40c.; 1b., \$1.25.

Bastian's Half-Long Blood-A very highly appreciated variety wherever grown; half-long shape and very dark blood-red color; an excellent variety for Winter use. Pkt. 5c.; oz., 10c.; $1 / 4$ lb., 30c.; 1b., \$1.00.

Buist's Improved Long Blood-An excellent late variety; resists drought better than any other sort. Flesh is dark red, tender and sweet. Pkt., 5c.; $1 / 2$ oz., 10c.; oz., 15c.; $1 / 4$ lb., 35c.; lb., \$1.10.

Swiss Chard, Giant Lucullus-The largest variety of Swiss Chard, the stalks are as thick and broad as Rhubarb; the plants grow to a height of two and one-half feet; the leaf portion is heavily crumpled, very crisp and tender, and is used like Spinach. The stalks are delicious when cooked and served like Asparagus. Pkt., 5c.; oz., 10c.; I/4 lb., 30c.; lb., $\$ 1.00$.

Swiss Chard, Large Ribbed-Large broad green leaves, tender and fine flavor. Very strong grower. Pkt., 5c.; Oz., 10c.; I/4 lb., 30c.; 1b., $\$ 1.00$. 


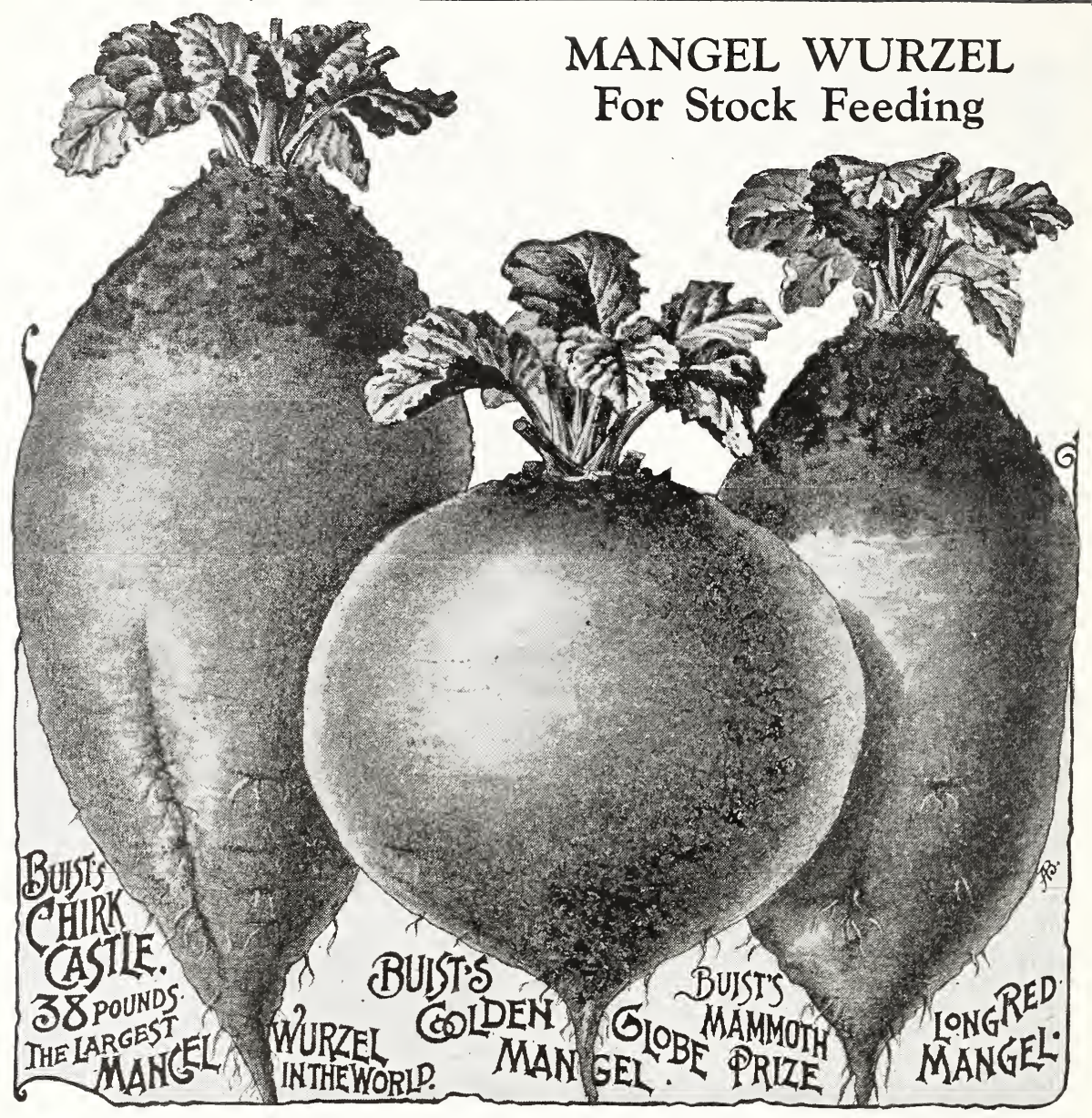

Mangel Wurzel, also called Mangel or Stock Beet, has become a very popular crop as the roots give an immense yield of valuable food at small cost for cattle, hogs, sheep and poultry. They excel as a Winter feed, as they keep all stock in a healthy condition, increase the yield of milk, and save in fodder. In feeding, they should be sliced, and are even better if steamed and mixed with bran. Plant early in the Spring in drills $21 / 2$ feet apart, covering the seed $11 / 2$ inches with fine soil, firmly pressed down. Cultivate frequently, and when 3 inches high, thin out to stand 8 inches apart.

\section{THE CHIRK CASTLE MANGEL WURZEL}

A selection of the Mammoth Long Red, which originated in Scotland. Its size is prodigious and its productiveness unequalled. Specimen roots have been grown weighing 56 lbs., and a whole crop averaged 38 lbs. per root. It requires no more labor or care in its cultivation than the ordinary Mangel, but its yield is double that of any other variety. Pkt., 5c; oz., 10c; 1/4 lb., 25c; lb., 70c; 5 lbs., \$3.25.

\section{BUIST'S MAMMOTH PRIZE LONG RED MANGEL}

This famous variety is the result of continuous and careful selection. The great characteristic of our improved stock is the broad shoulder and massive character of the root, by which a greater weight is obtained without the coarseness which appears to be inherent in many stocks of Long Mangel. Is especially adapted to deep rich soil, and its production is enormous, single roots frequently weighing from 25 to 35 pounds. Pkt., 5c; oz., 10c; 1/4 lb., 20c; lb., 65c; 5 lbs., $\$ 3.00$.

\section{BUIST'S PRIZE GOLDEN GLOBE MANGEL}

This popular variety is remarkable for its immense size, beautiful shape, small top, clear skin, and single tap-root, as well as for its most excellent feeding qualities. If your soil is inclined to be shallow, this is the variety to grow to produce the largest yield. Pkt., 5c; oz., $10 \mathrm{c} ; 1 / 4 \mathrm{lb} ., 20 \mathrm{c} ; 1 \mathrm{lb} ., 65 \mathrm{c} ; 5 \mathrm{lbs} ., \$ 3.00$. 
GOLDEN TANKARD MANGEL WURZEL

This is an entirely distinct type of Mangel and highly prized wherever introduced. It is largely grown by dairymen and sheep raisers; the former prize it not only for its great yield, but for the rich character of the milk it produces. Pkt., 5c; oz., 10c; $1 / 4$ lb., 20c; 1b., 65c; $5 \mathrm{lbs} ., \$ 3.00$.

\section{GIANT HALF SUGAR MANGEL}

$A$ variety combining the best qualities of Sugar Beets and Mangels. The flesh is pure white, firm and highly nutritious. Roots grow half out of the ground and are thus easily harvested. Pkt., 5c; oz., 10c; 1/4 lb., 20c; lb., 60 c; 5 lbs., $\$ 2.50$.

\section{KLEIN WANZLEBEN SUGAR BEET}

The most desirable to grow; as it contains a greater per cent of sugar. Heavy yielder and easy to dig. Pkt., 5c; oz., 10c; $1 / 4$ lb., 20 c; lb., 60c; 5 lbs., \$2.50.

\section{„BRUSSELS SPROUTS}

Culture the same as mentioned for Cab. bage, except that the plants should be set 15 inches apart in rows 2 feet apart. The sprouts grow around upper part of stem and are ready for use as soon as they have had a touch of frost. This vegetable is Cabbage in its most delicate form.

\section{LONG ISLAND HALF DWARF}

Dwarf robust habit, producing compact sprouts of the finest quality. Pkt., 10c; 1/2 oz., 15c; oz., 25c; 1/4 lb., 75c; lb., \$2.50.

\section{DALKEITH}

Of dwarf habit; stems are thickly set with large, solid sprouts of delicious flavor. Very hardy. Pkt., 10c; 1/2 oz., 15c; oz., 25c; 1/4 lb., $75 \mathrm{c}$.

\section{PARIS MARKET}

Half dwarf, forming compact sprouts of superior flavor. Pkt., 10c; 1/2 oz., 15c; oz., 25c; 1/4 lb., 75c.

\section{BROCCOLI}

A vegetable similar to Cauliflower, but requires a longer season to develop. Culture same as Cauliflower. Very hardy and adapted to localities where the season is long, cool and moist.

\section{EARLY GREEN CALABRESE}

A variety of Broccoli largely grown by Italian market gardeners. Produces a bluish. green head at center of plant in about ninety days. After this head is cut, the plant produces many branches and lateral heads as desirable as the first head and continues to bear until frost. Can be cooked and served like either Asparagus or Cauliflower. Sow seed in frames early in Spring, or in the open ground in May. One ounce will produce 2000 plants. Pkt., 15c; 1/2 oz., 55c; oz., $\$ 1.00$; $1 / 4$ lb., $\$ 3.25$; lb., $\$ 12.00$.

\section{ITALIAN BROCCOLI (For Greens Only)}

Does not form a head, but produces a suc. cession of green shoots. Sown in the Fall, in drills 32 inches apart, it will sprout up in the early Spring like Asparagus, with leaves and flowers at the end of the shoot and will then be ready for market. Two pounds will sow an acre. Pkt., 5c; 1/2 oz., 10c; oz., 20c; 14 lb., 60c; lb., $\$ 2.00$.

\section{EARLY LARGE WHITE FRENCH}

The best variety; compact, white heads. A hardy, vigorous and easy grown sort, excellent flavor, can be sown either in Spring or Fall. Pkt., 10c; 1/2 oz., 30c; oz., 60c; 1/4 lb., \$2.00; lb., $\$ 7.00$.

\section{EARLY PURPLE CAPE}

Large heads; brownish-purple; excellent flavor; best variety for North. Pkt., 10c; 1/2 oz., 30c; oz., 60c; 1/4 lb., \$2.00; lb., \$7.00.

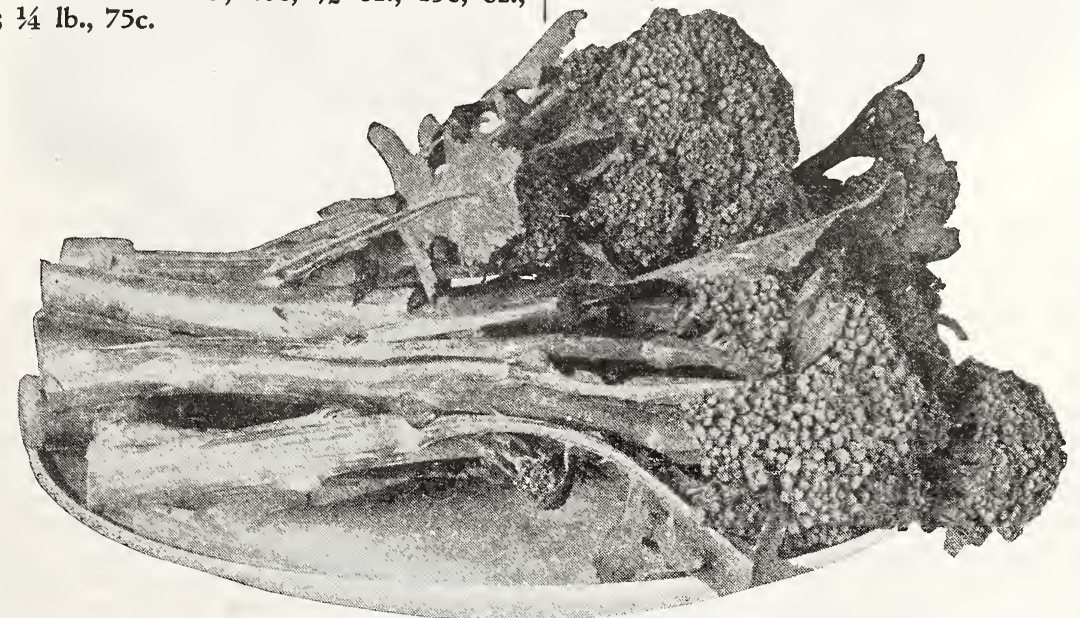

Early Green Calabrese Broccoli 


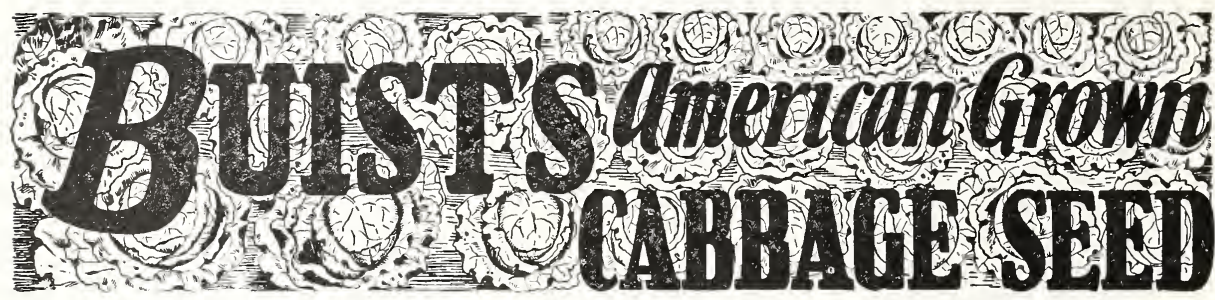

\section{INTRODUCTORY}

Our Cabbage seeds are all grown from selected stocks, carefully inspected while growing, and also before being put away for the Winter. No finer or purer strains of Cabbage can be found anywhere than the Buist's high-bred "Prize-Medal" American grown stocks.

For early Cabbage (where a supply of Fall-grown plants have not been secured) sow on a gentle hotbed very early in the season, and as the plants grow, harden them to the full exposure of the air, protecting them from frost until the middle of Spring, when they should be planted in rows two feet apart, and eighteen inches in the row. It may be observed that good heads can only be obtained when the ground has been well worked and highly manured. To seccure a supply of Fall-grown plants, the seed should be sown in September, from the fifteenth to the twentieth, in Pennsylvania. In mild climates they should be planted out late in Autumn, to remain for heading, but in cold latitudes they must be protected in cold beds or frames, and transplanted early in Spring.

For Fall and late Winter Cabbage the seed should be sown from the middle to the end of Spring, in beds of rich earth, and transplanted in June or July during moist weather, giving them a thorough watering at time of removal. The late Spring sowings are, in many situations, destroyed by the cabbage-fly as fast as the plants appear. It is always the best plan to sow plenty of seed. The plants must have a copious watering every morning until they are transplanted.

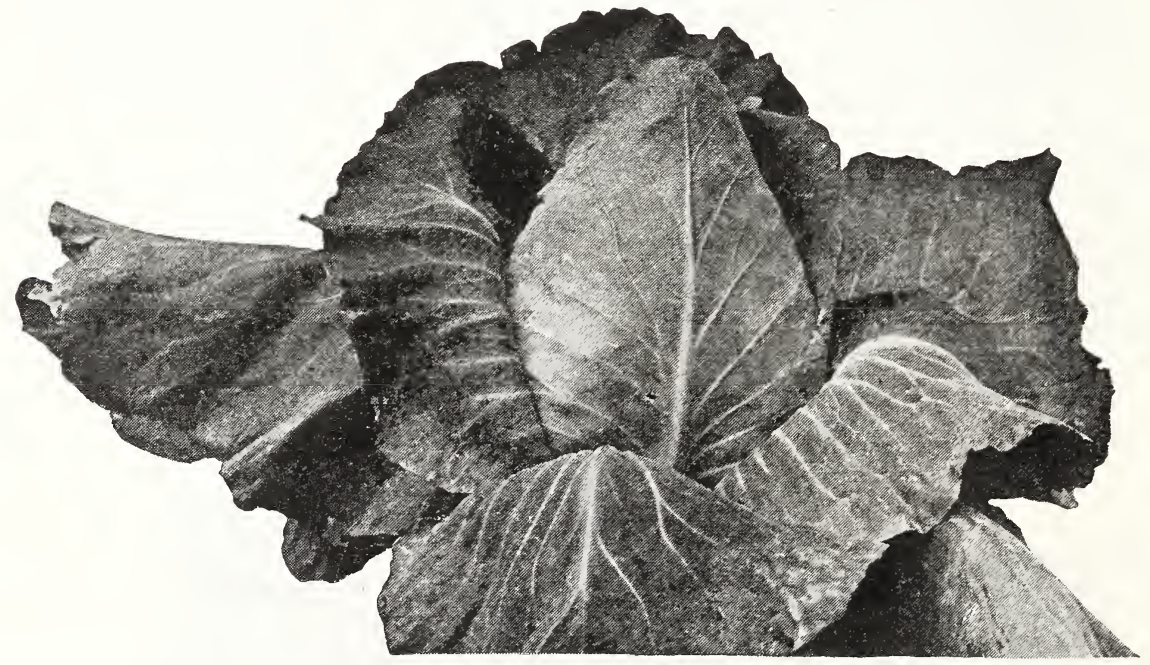

Buist's Early Jersey Wakefield

Early Jersey Wakefield (Buist's Selected Strain)-Undoubtedly the finest strain of this most popular well-known early Cabbage in cultivation. Each year the demand is becoming greater and it is more largely grown than all the other first early Cabbages combined. The heads are extremely solid, pyramidal in shape and of most excellent quality, with little outside foliage. Its exceeding hardiness makes it the most profitable early variety to grow for either market or home garden, as it always forms a fine solid head. This special stock or strain is famous everywhere, both with market gardeners and private growers. It is sold only under our seal. Plkt., 10c.; I/2 Oz., 15c.; Oz., 30c.; $1 / 4$ lb., 90c.; lb., \$3.00. 


\section{CABBAGE, First Early Varieties}

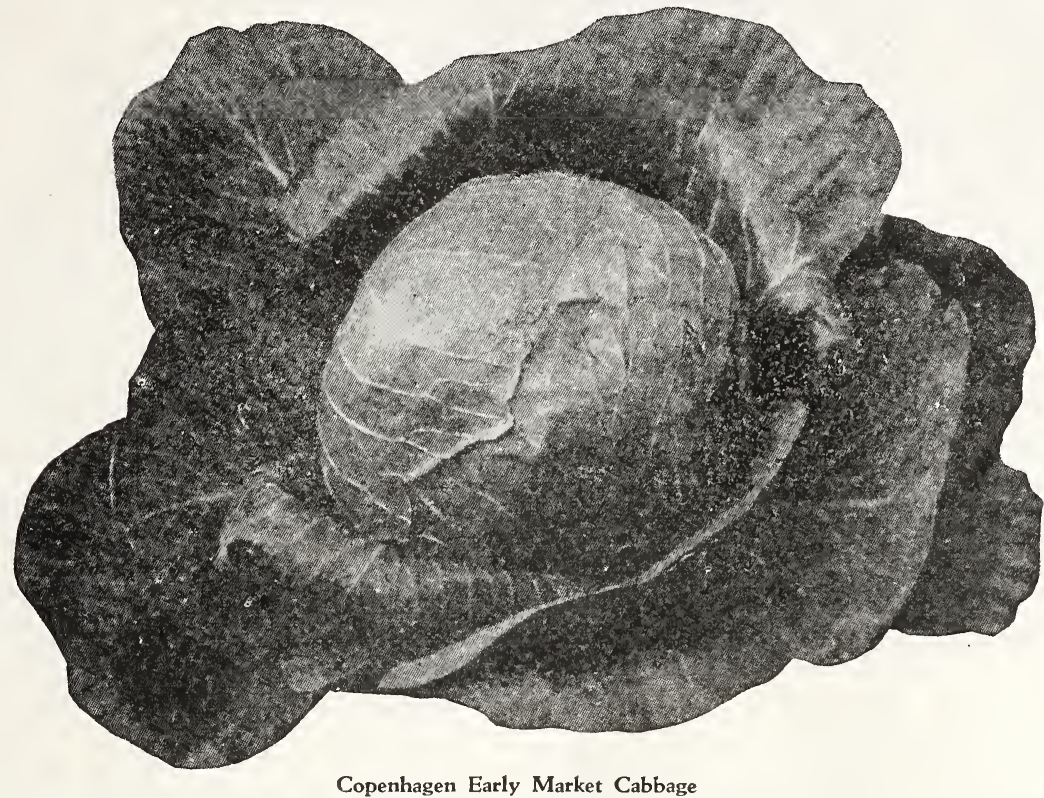

\section{COPENHAGEN EARLY MARKET}

This is one of the earliest and largest of all the early round headed varieties. It matures so uniformly that the entire crop is ready for cutting at one time, and it is as early as the Charleston Wakefield.. The plants are short stemmed, producing heads close to the ground, and will average ten pounds; the leaves are light green and round, dish-shaped, folding tightly together; the plants may, therefore, be set closer together than other early varieties. The round heads are very solid and of exceptionally good quality. Recommended highly for the home and market garden. Our strain is exceptionally fine. Pkt., 10c; 1'́2 oz., 25c; oz., 45c; 1/4 lb., $\$ 1.50 ; \mathrm{lb} ., \$ 5.00$.

\section{BUIST'S EXTRA EARLY JERSEY WAKEFIELD CABBAGE}

Identical with Jersey Wakefield, but will cut a week earlier. Heads of medium size, very solid and of compact growth. Pkt., 1.0c; 1/2 oz., 15c; oz., 30c; 1/4 lb., 90c; lb., \$3.00.

\section{EARLY WINNIGSTADT}

This is one of our most popular varieties, especially among the European gardeners. There is no early sort which heads with greater certainty, or more solidly; the heads are of good size, cone form, broad at the base, with twisted top. To those who have never tried this variety, we say, by all means, plant it; it is invaluable for either market or family use. Pkt., 10c; 1/2 oz., 15c; oz., 25c; 1/4 lb., 75c: $1 \mathrm{~b} ., \$ 2.50$.

\section{THE CHARLESTON OR LARGE JERSEY WAKEFIELD}

This famous variety has all the fine qualities of the Early Jersey Wakefield with heads much larger, but less pointed, and remarkably uniform in size and shape. It is a week or ten days later than Jersey Wakefield. Grown very extensively in the South and very popu. lar with market gardeners and shippers. Pkt., $10 \mathrm{c}$; 1/2 oz., 15c; oz., 30c; 1/4 lb., 90c; lb., $\$ 3.00$.

\section{GOLDEN ACRE}

This new Danish introduction, which closely resembles the Copenhagen Market and is ten days earlier, is highly recommended by all who have grown it. The heads are not quite so large as the Copenhagen, but more uniformly round and can be planted closer. Because of its earliness and fine qualities, it commands a price that spells prosperity for the market gardener. Our strain is of superior quality in earliness, uniformity of size, and time of maturity. Pkt., 15c; 1/2 oz., 35c; oz., 60 c; $1 / 4$ lb., $\$ 2.00$; lb., $\$ 7.00$.

\section{BUIST'S EARLIEST FLAT HEAD}

This variety has given such great satisfaction that we consider it peerless among the early sorts. Combined with earliness, it unites compactness with excellent quality; almost flat heads and quite large for an early strain; hav. ing a short stem and but few outside leaves, permits of close culture. Pkt., 10c; 1/2 oz., $15 c$; oz., 30c; 1/4 lb., \$1.00; lb., $\$ 3.50$. 


\section{Early Summer and Fall Varieties of Cabbage}

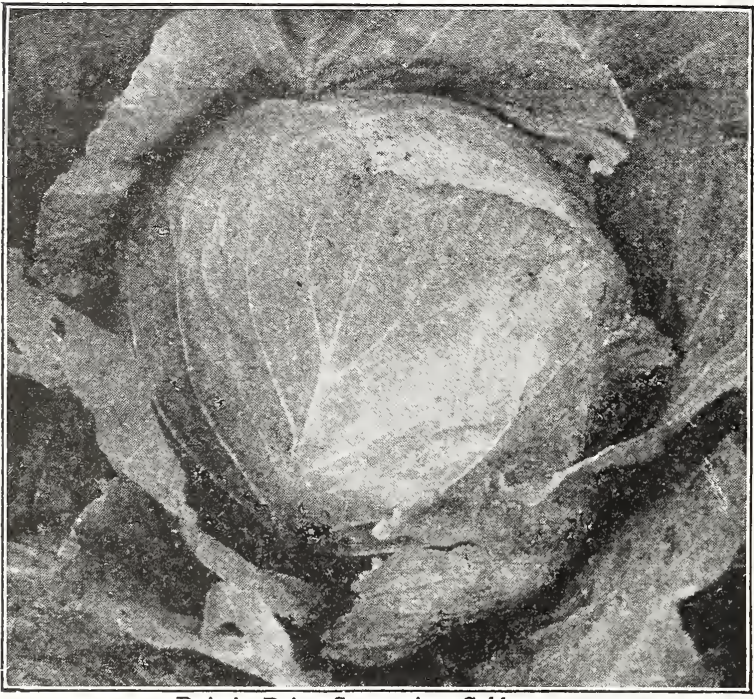

Buist's Prize Succession Cabbage

Buist's Prize Succession-A thoroughbred second early Cabbage, pronounced by experts the most perfect type grown. Especially recommended on account of its uniform size and shape, about a week later than Early Summer, but much larger heads, averaging twelve to fifteen pounds in weight, 36 inches in circumference, every plant producing a fine, solid head. One of the surest varieties to make a crop under all conditions, and does well in all seasons, no matter when planted. Pkt., 10c.; $1 / 2$ oz., 15c.; oz., 30c.; I/4 lb., \$1.00; lb., \$3.50.

Henderson's Succession-This recentlyintroduced variety, which originated on Long Island, we regard as a valuable acquisition to the famous Early Summer, but produces heads of very much larger size. Regarded as the best second-early Cabbage in cultivation. Pkt., 10c.; $1 / 2$ oz., 15c.; oz., 30c.; 1/4 lb., 90c.; lb., $\$ 3.00$.

Buist's Early Flat Dutch-This variety is equally as popular as the Early Drumhead. In fact the only distinction between them is the form of the head, which although equally as solid and as large in size, is almost flat. It is a sure header and very extensively planted. Sold only under our seal. Pkt., 10c.; T/2 oz., 15c.; oz., 25c.; 1/4 lb., $75 \mathrm{c}$; 1 1b., $\$ 2.50$.

Glory of Enkhuizen-The heads are globe shaped, very solid, and of large size for so early a variety. Exceedingly tender and fine flavor. Pkt., 10c.; $1 / 2$ oz., 20c.; oz., 35c.; I/4 lb., \$1.15; lb., $\$ 4.00$.
Henderson's Early SummerThis is a very valuable variety, not only for the market gardener, but also the private grower, as its heading season is between the Jersey Wakefield and Early Drumhead, producing heads of double the size of the former and almost equal to the latter, frequently weighing from twelve to twenty pounds each; of round-flattened form, very compact, solid, and of excellent quality; its leaves turn into the heads almost as soon as formed, which permits of close planting. Pkt., 10c.; I/2 Oz., 15c.; Oz., 30c.; 1/4 lb., 90c.; lb., $\$ 3.00$.

Allhead Early-This is the earliest of all the large heading Summer varieties, and cannot be too highly recommended for private growing or for the market gardener. It produces deep, flat, compact heads, which are as solid as a rock, hence its name Allhead. Pkt., 10c.; r/2 oz., 15c.; oz., 30c.; I/4 1b., 90c.; lb., \$3.00.

All Seasons (Vandergaw) - This variety is a selection of the Early Drumhead, and one that cannot be too highly recommended. It can be raised either for an early, intermediate or late crop; in fact, it is a sure-heading variety at any season of the year. The heads are large, very solid, of fine grain, and remain perfect a long time without bursting. Pkt., 10c.; $1 / 2$ oz., 15c.; Oz., 25c.; $\mathrm{r} / 4$ ib., 75c.; lb., $\$ 2.50$.

Buist's Brunswick Drumhead-For the past few years we have paid special attention to the improvement and selection of this variety and the seed we offer will be found superior to any in the world; it is perfection in growth, habit and formation of heads, which are much larger, more compact, and closer grain than the old Brunswick. Pkt., 10c.; $1 / 2$ oz., 15c.; Oz., 25c.; $1 / 4$ lb., 75c.; lb., $\$ 2.50$.

Buist's Early Drumhead-This popular variety is ready for marketing two or three weeks earlier than the Late Drumhead, forms large, solid, rounded heads, weighing on an average from fifteen to twenty-five pounds each. As a market variety it is really indispensable, especially for the South, as it withstands the heat remarkably well. Sold under our seal. Pkt., 10c.; r/2 oz., 15 c.; oz., 25c.; 1/4 lb., 75 c.; lb., $\$ 2.50$. 


\section{CABBAGE, Autumn and Winter Varieties}

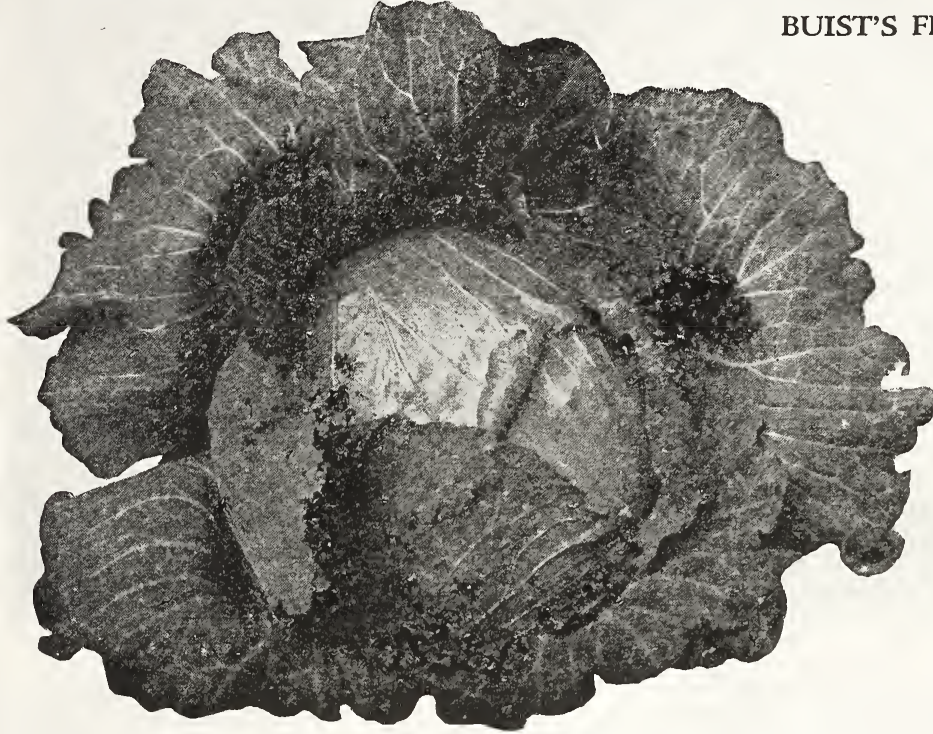

Buist's Late Flat Dutch Cabbage

This variety, which we introduced, has become famous throughout the South, and has taken the front rank for its certainty of heading and fine $\mathrm{m}$ a r k e t qualities. The growers say they have never had any variety to equal it, scarcely a failure can be found in whole fields. Heads average from fifteen to thirty pounds each; it is much earlier than Drum. head or Flat Dutch. Sold only under our seal. Pkt., 10c; 1/2 oz., 15c; oz., 25c; 1/4 lb., 80c; lb. $\$ 2.75$.

\section{BUIST'S PRIZE MEDAL LATE FLAT DUTCH}

This celebrated variety has been grown by us for many years and is the result of con. tinued care to develop and maintain the good qualities which has made it the most popular variety for a main crop. The continued im. provement for so long a period has produced a stock of Late Flat Dutch Cabbage that has no equal for compact growth, and for large, beautiful heads, and is esteemed one of the best late Fall and Winter Cabbages. It is a good keeper and shipper. Sold only under our seal. Pkt., 10c; 1/2 oz., 15c; oz., 25c; 1/4 lb., 75c; lb., $\$ 2.50$.

\section{BUIST'S PRIZE MEDAL LATE DRUMHEAD}

Similar in every respect to Buist's Late Flat Dutch in its growth and general habits, but producing heads which have a more rounded top. Sold only under our seal. Pkt., 10c; 1/2 oz., 15c; oz., 25c; 1/4 lb., 75c; lb., $\$ 2.50$.

\section{SUREHEAD}

This variety is appropriately named, as it certainly is a sure header and one of the best for a main crop. Heads are large, broad and somewhat flattened, weighing from 10 to 15 pounds each, of excellent quality. It is extremely popular with market-gardeners, owing to its certainty of heading. Pkt., 10c; 1/2 oz., 15c; oz., 25c; 1/4 lb., 75c; lb., \$2.50.

\section{LOUISVILLE DRUMHEAD}

Highly esteemed by the market gardeners of the Southwest. Pkt., 10c; 1/2 oz., 15c; oz., $25 \mathrm{c} ; 1 / 4 \mathrm{lb} ., 75 \mathrm{c} ; \mathrm{lb}$., \$2.50.

\section{NEW VOLGA}

This Russian introduction has proven the quickest growing, large, late variety; it is two to three weeks earlier than any other large kind. The plants have short stems, grow close to the ground, producing solid heads that will average fifteen pounds; round as a ball, of fine quality, being very white, crisp and tender. Grows very compact, which per. mits of close planting. It is a splendid drought resister and an elegant sort for the South. Pkt., 10c; 1/2 oz., 15c; oz., 30c; 1/4 lb., $90 \mathrm{c} ; \mathrm{lb} ., \$ 3.00$.

\section{THE HOUSER}

A late variety of excellent qualities, producing large, solid heads, round and deep, averaging twelve pounds. It is a strong, vigorous grower, with ability to withstand drought better than most varieties and is about two weeks later than the Late Flat Dutch or Drumhead. A good keeper and a sure header. Pkt., 10c; 1/2 oz., 25c; oz., 45c; 14 lb., \$1.50; lb., \$5.00.

\section{PREMIUM LARGE LATE FLAT DUTCH}

One of the oldest varieties in existence, producing large, solid heads of bluish green, with a broad and flat surface, when touched with frost the outer leaves become tinted with reddish-brown; the head is white, crisp and tender. Pkt., 10c; oz., 20c; 1/4 lb., 65c; lb., $\$ 2.25$.

\section{PREMIUM LATE DRUMHEAD}

The heads are uniformly large, rounded at top, very solid and a good keeper. Pkt., 10c; oz., 20c; 1/4 lb., 65c; lib., \$2.25. 


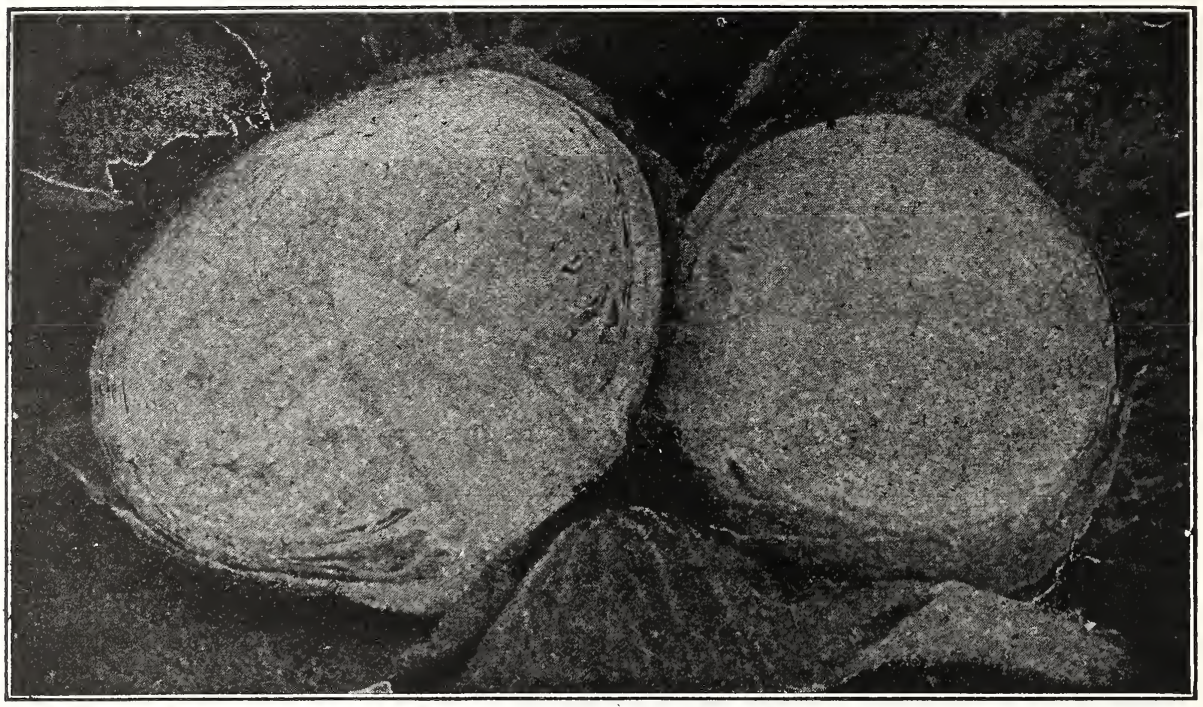

Danish Ball Head Cabbage

Danish Ball Head-This variety has become famous in this country and cannot be too highly recommended. It has also been for over a century the famous Cabbage of Denmark, and is about the only variety grown by the market gardeners of that country and the adjacent islands of the Baltic for an early Summer, Fall or Winter crop, which is exported in large quantities. It is so highly prized that there is a great rivalry among them in the improvement of the stock seed, which each one raises for his own sowing; the heads are round, very solid, of medium size, fine grain and good keepers; for boiling, slaw or sauer-kraut it is unsurpassed. The seed which we offer is of our own importation direct from one of the most extensive growers of Denmark. Pkt., 10c.; 1/2 oz., 20c.; oz., 35c.; 1/4 lb., \$1.15; lb., \$4.00.

Danish Round Head-This variety is a short stemmed type of the famous Danish Ballhead and has become very popular during the past few years. Heads are round, larger and earlier than the Danish Ballhead. It is highly esteemed for Winter because of great solidity and excellent keeping qualities. Pkt., 10c.; 1/2 oz., 20c.; oz., 35c.; $1 / 4$ lb., $\$ 1.15 ; 1 b ., \$ 4.00$.

\section{CURLED SAVOY CABBAGE}

American Perfection Drumhead Savoy-A variety of Cabbage producing beautiful curled leaves; when touched by frost becomes very tender and delicious in flavor, closely resembling the delicacy of cauliflower. This is the largest heading Savoy and the best for either market or family use. Pkt., 10c.; $1 / 2$ oz., 15c.; 0z., 30c.; $1 / 4$ lb., 90c.; 1b., $\$ 3.00$.

\section{RED CABBAGE}

Mammoth Red Rock-This recently-introduced variety is the largest of the red varieties, producing heads averaging from 10 to 15 pounds each; the heads are of a deep red color to the very center, and as solid as a rock; it is best of all for boiling purposes. Pkt., 10c.; $1 / 2$ oz., 15c.; oz., 30c.; $1 / 4$ lb., $\$ 1.00 ; 1 b ., \$ 3.50$.

Red Danish Stonehead-Produces ball-shaped heads of great solidity and of a dark red color. Pkt., 10c.; $1 / 2$ oz., 20c.; oz., 35c.; $1 / 4$ lb., \$1.15; lb., \$4.00.

Red Dutch-This sort is principally used for pickling; the head is of medium size, very solid, of a heart shape, and of a purplish-red color. The darker the color, and the thicker and more fleshy the leaves, the more valuable; it is in perfection from October until Christmas. Pkt., 10c.; Oz., 30c.; $1 / 4$ lb., $\$ 1.00 ; 1 b ., \$ 3.00$.

\section{CHINESE OR "CELERY" CABBAGE}

Sow about the same time as Turnips and other Fall vegetables in rows $21 / 2$ feet apart, thinning to 12 inches in the rows. Early plantings shoot to seed. One ounce will sow 500 feet of drill.

Pe-Tsai-Forms heads like Cos Lettuce. Very crisp and tender. Pkt., 10c.; I/2 oz., 20 c.; Oz., 30c.; $1 / 4$ lb., 90c.; lb., $\$ 3.00$.

Wong Bok-Produces a heavier and more solid head than Pe-Tsai. The leaves blanch almost white. Pkt., 10c.; $1 / 2$ oz., 20c.; 0z., 30c.; $1 / 4$ lb., $\$ 1.00 ; 1 b ., \$ 3.50$. 


\section{CARROT}

This vegetable requires a deep, rich, light, sandy soil, well manured. If the ground is not of this quality, it should be dug deep and well broken the year previous. If for field culture, the ground should be sub-soiled, as in all shallow or hard soils the roots fork or spread in a lateral direction, injuring both their size and quality. Sow early in Spring, in shallow drills, half an inch deep and nine to twelve inches apart, which admits of the hoe being made use of in thinning out the crop and clearing off the weeds. As soon as the plants are up and can be distinctly observed in the rows, take a 3-inch hoe and thin them out to two or three inches apart. The main crop intended for Fall and Winter, should be thinned to 6 inches apart. Frequent stirring of the soil is very essential to the growth of the roots. Should the surface of the soil become baked before the young plants appear, loosen it by gentle raking. From the 1st of May till the 1st of June is the period to sow for a main crop. In the Southern States they can be sown in the Fall and will continue growing all Winter and be fit for the table in early Spring. The seed will germinate more freely in dry weather by soaking it twelve hours in cold water, and mixing with sand before sowing. The crop is ready for harvesting as soon as the tops commence turning yellow. They should be taken up in dry weather. Cut off the tops to within about an inch of the crown and pack the roots in dry earth or sand in the cellar for Winter use; or they may be pitted out of doors, covered with two inches of straw and a foot of earth, to keep them from frost, when they can be used until the following April. Beets and all similar roots can be kept in the same manner.

Buist's Improved Early Half-Long Scarlet-This is also known as the French Intermediate. It is a very popular variety not only in France, but with all market gardeners of this country. The roots are eight or ten inches in length, very broad at the neck and two to three inches through, of scarlet color, beautiful tapering form. It is two weeks later than the Scarlet Horn, grows smoothly and uniformly. Sweet, tender and entirely free from any coarseness, even at maturity. Has yielding capacity equal to any. Pkt., 5c.; $1 / 2$ oz., 10c.; oz., 15c.; $1 / 4$ lb., 40c.; lb., \$1.25.

Danvers Half-Long Scarlet-An intermediate or half-long variety. Stumprooted, of a bright orange red color, very smooth and handsome. As a carrot to fill every general purpose it is unexcelled; no other produces such generally good qualities, very productive, twenty to thirty tons to the acre not being an unusual crop. A most desirable sort for market gardeners. Pkt., 5c.; $1 / 2$ oz., 10c.; oz., 15c.; $1 / 4$ lb., 40c.; lb., \$1.25.

Early Half-Long Scarlet ChantenayThis variety is a great favorite in the Paris markets and the most popular with the French gardeners. It may be called a model or perfect variety, not only for its brilliant orange-scarlet color, but for its great uniformity of growth, its earliness, productiveness and fine flavor. Has broad. shoulders and root tapering abruptly at the end. It is earlier than the Half-Long Danvers and one of the most salable market varieties. Pkt., 5c.; I/2 oz., 10c.; oz., 15c.; $1 / 4$ lb., 40c.; lb., $\$ 1.25$.

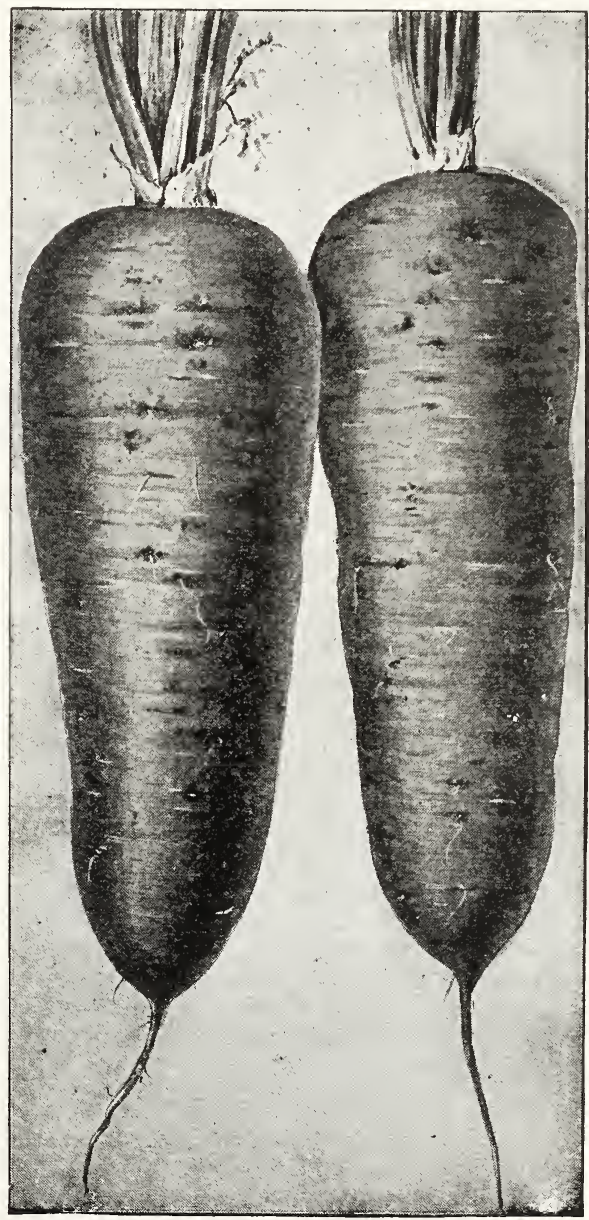

Danvers Half-Long Scarlet Carrot 


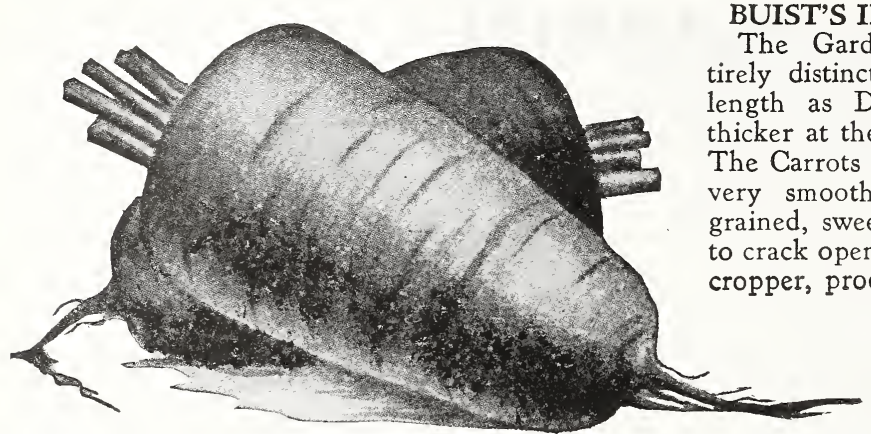

Buist's Improved Rubicon Carrot

BUIST'S IMPROVED RUBICON ardener's Favorite-An entirely distinct variety, about the same as Danvers, but heavier and tiso earlier. Carrots grow about 6 inches long, smooth, rich orange red, fine grained, sweet sugary, and are not apt to crack open while growing. A heavy cropper, producing thirty to forty tons to the acre under good cultivation. One of the best bunch Carrots. Pkt., 5c; 1/2 oz., 10c; oz., 15c; 1/4 lb., 40c; lb., $\$ 1.25$.

\section{BUIST'S SPECIAL DANVERS}

This selected stock we are now offering has been specially grown for market-gardeners and is sure to give satisfaction. The roots are very uniform in shape and size and the flesh is of a dark orange color. Its yield per acre is greater than that of any other sort. Pkt., $5 c$; 1/2 oz., 10c; oz., 15c; 1/4 1b., 50c; 1b., \$1.50.

\section{BUIST'S IMPROVED LONG ORANGE}

The most popular variety for a general crop; of a bright scarlet color and very productive. In deep rich soil will frequently grow 12 inches in length, and produce 600 bushels to the acre. Pkt., 5c; 1/2 oz., 10c; oz., 15c; 1/4 lb., 40c; lb., \$1.25.

\section{SAINT VALLERY HALF-LONG SCARLET}

The roots grow very regular and smooth; they are of good size, being from 10 to 12 inches in length and 2 to 3 inches in diameter at the top, tapering gradually from the shoulder to the tip; valuable for its great productiveness, and also for its rich color and sweet flavor. Pkt., 5c; 1/2 oz., 10c; oz., 15c; 1/4 lb., 40c; lb., \$1.25.

\section{EARLY HALF-LONG SCARLET NANTES}

This popular variety is one of the hand. somest in shape of the medium size varieties. The roots are of a beautiful scarlet color, perfectly cylindrical in, form, with a blunt rounded point, smooth skin, and neck hol. lowed out around the leaf-stalk; flesh sweet and of mild flavor. Pkt.g 5c; 1/2 oz., 10c; oz., 15c; 1/4 lb., 50c; lb., \$1.50.

\section{EARLY OX-HEART, OR GUERANDE}

We recommend this carrot as possessing qualities of exceptional merit. A good yielder and the best for heavy, stiff soils. The shape is nearly oval and the color and quality all that can be desired. Pkt., 5c; 1/2 oz., 10c; oz., 15c; 1/4 lb., 40c; lb., \$1.25.

\section{EARLY FRENCH FORCING, OR SHORT HORN}

A favorite Carrot of small size, prized on account of its extreme earliness and superior flavor; best for forcing. Pkt., 5c; oz., 15c; $1 / 4$ lb., 50c; lb., $\$ 1.50$.

\section{EARLY SCARLET DUTCH HORN}

This has always been the general favorite for an early crop. It is of a bright orange color, of delicate flavor. Owing to the shortness of the root, it will grow in less depth of soil than any other variety. This variety has a very great reputation among market gardeners for its beautiful form and attractive appearance for bunching. Pkt., 5c; 1/2 oz., $10 \mathrm{c} ;$ oz., 15c; 1/4 lb., 50c; lb., $\$ 1.50$.

\section{Stock Feeding Carrots}

Carrots make an excellent feed for horses and dairy cattle used with corn and fodder. They are highly nutritious and will keep the stock in good condition.

\section{IMPROVED SHORT WHITE}

An enormous yielder. The roots are short and heavy at the shoulder, frequently meas. uring 15 inches in circumference, tapering to a point. The flesh is solid, white and sweet. Pkt., 5c; oz., 10c; 1/4 lb., 30c; lb., \$1.00.

\section{LARGE WHITE BELGIAN}

A heavy producer, the roots 12 inches in length and 2 inches thick at the shoulder. Pkt., 5c; oz., 10c; 1/4 lb., 30c; lb., \$1.00.

\section{LARGE YELLOW BELGIAN}

Similar to the above, but of a pale orange color. Flesh is light yellow. Pkt., 5c; oz., $10 \mathrm{c} ; 1 / 4$ lb., 30c; lb., $\$ 1.00$.

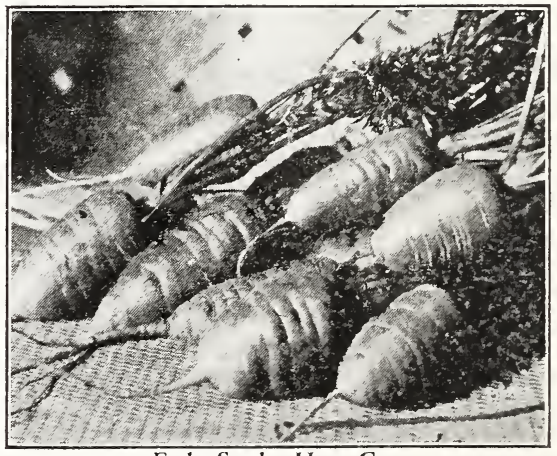

Early Scarlet Horn Carrot 


\section{GAULIFLOWER}

Culture-Same as Cabbage. They require rich, well-drained soil and plenty of water. For an early Spring crop, start seed indoors and set out in the open ground about April 15. For a Fall crop sow seed June 1st and transplant about July 15th. After the head reaches a diameter of four inches, gather the leaves together and tie them at the top to blanch heads and prevent injury from sun and frost. Set out the plants 15 to 18 inches apart in 3 -foot rows. One ounce will produce 1500 plants.

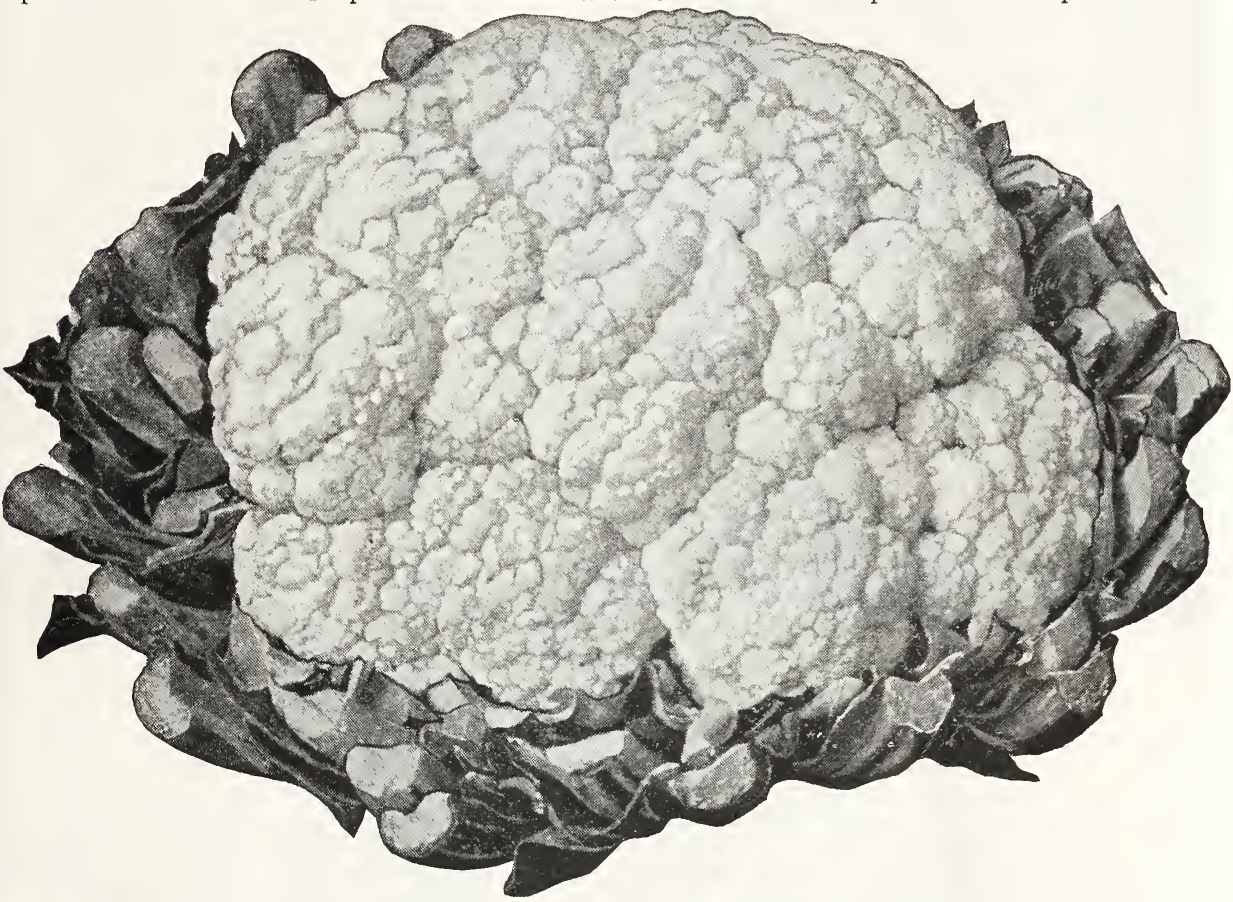

Buist's Prize Early Snowball Cauliflower

Buist's Selected Early Snowball-The Snowball is a famous variety throughout the world, and Buist's is regarded as one of the finest strains; it is, without question, the best for either market or private growing; there is no variety earlier, and none that heads with greater certainty; the heads are large and beautifully formed and of the most delicate flavor, and averaging nine to ten inches in diameter, of very close and compact growth, with very short outer leaves, enabling one-third more to be grown in the same space than any other variety; it eclipses them all for either forcing or cold-frame culture. Pkt., 25c.; or 5 pkts., $\$ 1.00 ; 1 / 4$ Oz., 75 c.; $1 / 2$ Oz., $\$ 1.35$; oz., $\$ 2.50 ; 1 / 4$ lb., $\$ 8.00$.

Famous Dry Weather-This variety is the best for localities subject to long dry seasons, as it will often produce heads of fine quality under these conditions while other sorts are total failures. Heads are large, and of the most delicate flavor. Pkt., 25c.; I/4 oz., 75c.; I/2 oz., $\$ 1.35 ;$ oz., $\$ 2.50 ; 1 / 4$ lb., $\$ 8.00$.
Extra Early Dwarf Erfurt-A favorite early market variety, and very desirable for forcing, producing large, white, firm heads of excellent quality. The heads, when ready for market, are of medium size. A desirable variety for either the home garden or market. Pkt., 25c.; I/2 oz., \$1.35; oz., \$2.50; $1 / 4$ 1b., $\$ 8.00$.

Algiers-A famous late variety, producing fine, large, solid, white heads; it is a strong grower and a sure header. Pkt., 10c.; $1 / 2$ oz., 50c.; oz., 90c.; $1 / 4$ lb., $\$ 3.00$.

Extra Early Paris-The best known of all the varieties; tender and delicious. Pkt., 10c.; I/2 oz., 50c.; oz., 90c.; I/4 lb., $\$ 3.00$.

Lenormand's Short Stem-A superior variety, with fine, large and well-formed heads. Pkt., 10c.; $1 / 2$ oz., 50c.; oz., 90c.; $\mathrm{r} / 4 \mathrm{lb}$., $\$ 3.00$.

Veitch's Autumn Giant-A valuable and distinct late variety, producing large, white, firm heads, well protected by the foliage. Pkt., 10c.; I/2 oz., 35c.; oz., 60c.; I/4 lb., $\$ 2.00 ; 1$ b., $\$ 7.00$. 


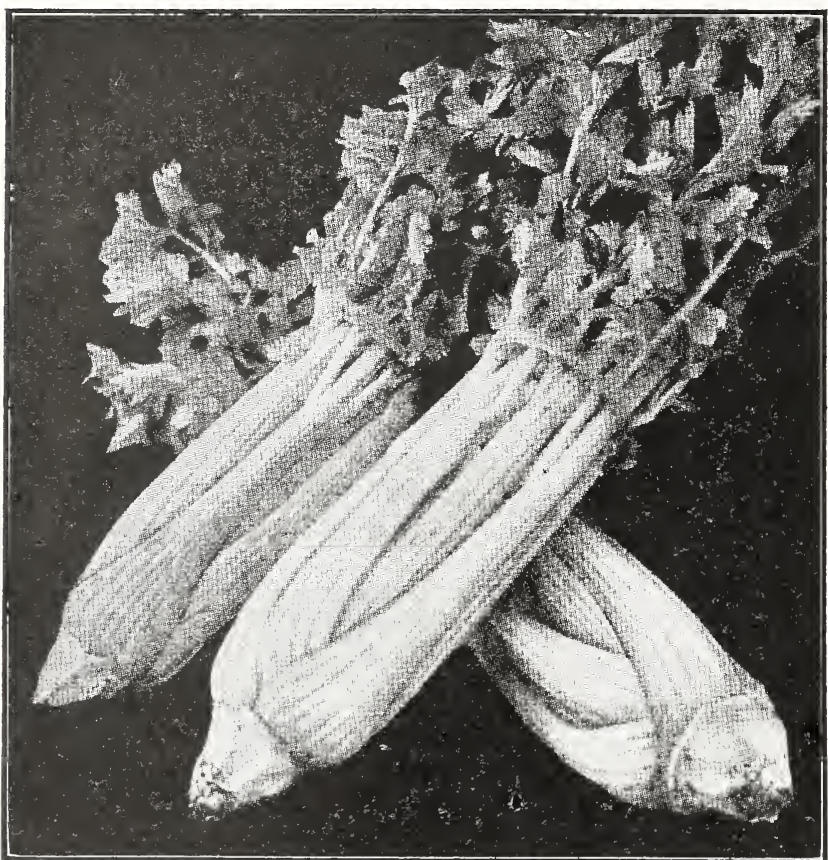

Wonderful or Golden Plume Celery
GOLDEN SELF-BLANCHING

Finest French Grown-The best and most reliable variety for early market. No celery offered approaches in color, flavor and habit of growth our stock of Golden Self-Blanching Celery. We secure our seed from the intro. ducer, a noted grower of France, and recom. mend this particular stock to our customers to be absolutely reliable in every respect and far superior to the ordinary strain on the market. The hearts are large and solid, blanching a beautiful rich golden yellow color; it is solid, crisp and brittle, free from stringiness and of delicious nutty flavor. Plants are of a medium size, uniform in height, with yellowish green foliage. Pkt., 10c; 1/2 oz., 50c.; oz., \$1.00; $1 / 4$ lb., $\$ 3.25 ; 1 b ., \$ 12.00$.

American Grown-We offer American grown seed of this variety. This seed is grown from the best selected French stock seed and is the best obtainable in this country; it has proven after repeated trials to be equal to the French. However, market gardeners prefer the French-grown stock and pay the price. Pkt., 10c; 1/2 oz., 25c; oz., 50c; $1 / 4 \mathrm{lb}$., $\$ 1.75$; lb., $\$ 6.00$.

\section{EASY BLANCHING}

Buist's Strain-This special strain of Easy Blanching we offer is the longest keeping variety grown, excelling in this respect every other sort. It is the easiest and quickest to blanch, stocky in growth and of medium height. The stalks are tender, brittle and attractive in appearance, of excellent quality and a rich nutty flavor. Pkt., 10c; 1/2 oz., 35c; oz., 65c; 1/4 lb., \$2.25; lb., \$8.00.

\section{CELERY}

Celery requires a rich, moist soil and does not germinate well in hot bed or a temperature in excess of $60^{\circ} \mathrm{F}$. Sow $1 / 4$ inch deep in seed beds very early in the spring. Trim tops once or twice before transplanting. When the plants are 6 inches high, transplant them 6 inches apart into trenches 4 inches deep, 9 inches wide and three feet apart. Firm the soil around the young roots, keep free from weeds and provide liberal water or soap suds in dry weather. Nothing more can be done until September, which is "handling" time for successful bleaching. Gather all leaves in one hand, pack. ing soil carefully around stalks to $1 / 3$ their height, so it does not fall between leaves and cause rust or rot. Repeat until only the tops can be seen.

\section{EMPEROR}

One of the finest and largest Winter varieties, dwarf in type and much easier to blanch than the taller growing varieties. The plants grow about 20 inches high, with rich, dark green foliage, and are resistant to disease and insect attacks. The stalks are smooth, solid and very thick. When blanched are pure white, the hearts showing a tinge of light buttery yellow; with a distinctly rich, crisp, nutty flavor. Pkt., 10c; 1/2 oz., 25c; oz., 45c; 1/4 lb., \$1.50; lb., \$5.00.

\section{WINTER KING}

An exceptionally fine Winter variety, and we recommend it especially to market gardeners. Its long-keeping qualities cannot be equaled, coming into use about last of November, maintaining its firmness until late in March, producing stalks of medium height, solid, crisp and of good flavor. We pronounce it the best green celery on the market. Pkt., 10c; 1/2 oz., 25c; oz., 45c; 1/4 lb., \$1.50; lb., $\$ 5.00$.

\section{WHITE PLUME}

A handsome, very early market variety, highly valued by gardeners because of its excellent market qualities; with consumers it is a favorite because of its crisp, tender, and desirable eating qualities. The stalks and portions of its inner leaves and heart are white, so that by drawing the soil up against the plant and pressing together with the hands, the work of blanching is complete without the necessity of banking or earthing up. It is not recommended as a long keeper. Pkt., 10c; 1/2 oz., 15c; oz., 30c; 1/4 lb., \$1.00; lb., \$3.00. 


\section{WONDERFUL OR NEW GOLDEN PLUME}

This new strain of Celery resembles the Golden Self-Blanching, but is much larger and ranker in growth, blanches more quickly, matures earlier and is more resistant to attacks of blight and rust. It has unquestionable merit in quality, flavor, sweetness and size. It grows well on muck and upland, and is absolutely the earliest Celery grown. A very profitable variety for growers for either the home or distant markets and also very desir. able for the hom e garden. Pkt., 15c; 1/4 oz., 45c; 1/2 oz., 80c; oz., \$1.50; $1 / 4$ lb., \$5.00; lb., $\$ 18.00$.

\section{GIANT}

WHITE

PASCAL

A rich green selection from the famous Self. Blanching. I t produces very broad and thick stalks, which are very crisp and tender, and of a very rich, nutty flavor; it re quires very little e a r th in $g$ up, bleaches rapidly, keeps well, and i s exceedingly crisp. Pkt., 10c; 1/2 oz., 15c; oz., 30c; 1/4 lb., 90c; lb., $\$ 3.00$.

\section{COLUMBIA}

An early maturing sort. The plant is of medium height, but very stocky a nd he avy. The foliage is of a distinctly light shade of green with a tinge of yellow. The stalks are thick, almost round, resembling in shape the Giant Pascal. A valuable variety for early Winter market. Pkt., 10c; 1/2 oz., 20c; oz., 35c; 1/4 lb., \$1.15; lb., \$4.00.

\section{WINTER QUEEN}

A desirable long keeping Winter celery, with double the amount of hearts of any known variety. It is easily blanched because of its compact growth. The plants are moderately dwarf, erect, and blanch to a beautiful creamy white. Pkt., 10c; 1/2 oz., 15c; oz., 30c; $1 / 4$ lb., 90c; lb., $\$ 3.00$.

\section{BUIST'S GOLDEN YELLOW}

This is a most valuable variety for late Fall or early Winter use. The ribs are broad, the plant stocky and full hearted, blanching a beautiful golden yellow. It never becomes stringy or pithy, and the most critical garden. ers can depend on this variety to produce their early Celery. We consider it unsur, passed in its rich nutty flavor. A splendid early Celery for the home garden and highly recommended to the commercial grower. Pkt., 10c; 1/2 oz., 25c; oz., 45c; 1/4 lb., \$1.50; Íb., $\$ 5.00$.

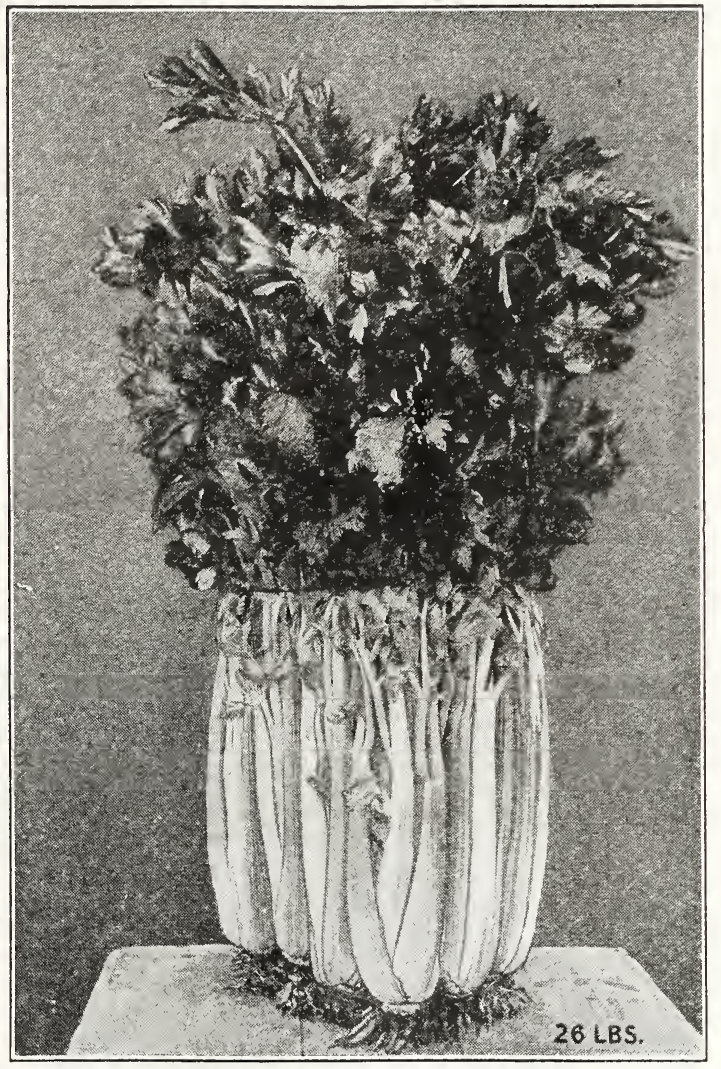

\section{GOLDEN}

\section{DWARF}

A very beauti. ful and valuable variety. The heart is large and of a waxy golden yellow, making its ap. pearance exceed. ingly attractive. It is very solid, a vigorous grower, easily blanched, crisp, tender, en. tirely free from stringiness and of a sweet nutty flavor. Pkt., 10c; 1'́2 oz., 20c; oz., 35c; $1 / 41 \mathrm{~b}$. , $\$ 1.15 ; \mathrm{lb}$., \$4.00.

Soup or Cutting Celery The green foli, age is used for flavoring soups and stews the same as parsley. Sow seed thickly in rows. Keep free from weeds; do not blanch. Pkt., 5c; oz., 15c; 1/4 lb., 50c; lb., $\$ 1.50$.

\section{CELERIAC}

Turnip-Rooted, or German Celery-This vegetable is grown exclusively for its roots, which are turnip-shaped, very smooth, tender and marrow-like. The roots are cooked and sliced; or, used with vinegar, they make an excellent salad.

Giant Prague-Excels in quality, size and appearance. Very uniform, skin smooth. Pkt., 10c; 1/2 oz., 15c; oz., 25c; 1/4 lb., 75c; lb., $\$ 2.50$.

Celery Seed for Flavoring-(Not for sow. ing.) Oz., 10c; 1/4 lb., 20c; 1b., 50c. 


\section{CHICORY}

Witloof Chicory or French Endive-This European delicacy has in the past few years become a standard salad in all of the best American hotels and restaurants. It can be easily grown. Seed is planted in the Spring and roots like parsnips are produced; which after lifting and resting a few days are replanted to form a new growth. The stalks when blanched make a delicious salad. Pkt., 10c.; oz., 20c.; 1/4 lb., 60c.; lb., $\$ 2.00$.

\section{CHIVES}

Chives are perfectly hardy perennial plants of the onion type. They are grown for the small leaves which come up very early in the spring and give a mild onion flavor to food in which they are placed. The tops may be cut off close to the ground as desired. Pkt., 10c.; I/4 oz., 25c.; 1/2 oz., 45c.; oz., 80c.

\section{CHERVIL}

The Curled Chervil is cultivated like Parsley and used for garnishing and flavoring soups and salads.

Curled Chervil - The young leaves are used for flavoring soups and salads. Pkt., 10c.; oz., 20c.; I/4 lb., 60c.; lb., $\$ 2.00$.

Plain Chervil-Like above, but not curled. Pkt., 10c.; oz., 20c.; I/4 lb., 60c.; lb., $\$ 2.00$.

\section{CORN SALAD}

The leaves should always be picked, not cut; if sown early in the Spring, in rows nine to twelve inches apart, it is fit for use in from six to eight weeks; but the proper time for sowing is September, and cover thinly with straw or hay when cold weather sets in. There are two varietie;, the large and small seeded; the former is the best, as it produces larger leaves. Pkt., 5c.; oz., 15c.; 1/4 lb., 40c.; lb., \$1.25.

\section{SOUTHERN COLLARDS}

Collard is scarcely known in any other section of this country, but in the South, where it originated, and where it is cultivated more extensively than any other vegetable, because it is well adapted to that country and is always a sure crop. It is almost a daily dish for rich or poor and for both man and beast. It is a species of Cabbage, which is not only very hardy, but a vigorous and continuous grower, producing a mass of leaves and very good heads; the former are stripped off and used as they form, the plant continues growing and finally heads. The crop is much improved by a touch of frost.

Georgia White Stem-Pkt., 5c.; oz., 10c.; Buist's Cabbage-Pkt., 5c.; oz., 10c.; 1/4 $\mathrm{I} / 4 \mathrm{lb} ., 25 \mathrm{c}$.; lb., $75 \mathrm{c}$.

Southern Blue Stem-Pkt., 5c.; oz., 10c.;

I/4 lb., 25c.; lb., 75c.

lb., 30c.; lb., 90c.;

North Carolina Buncombe - Pkt., 5c.; oz., 10c.; $1 / 4$ lb., 30c.; lb., 90c.

\section{SUGAR GORN (for Garden Culture)}

Plant about the last of Spring, in hills about three feet apart each way; dwarf varieties can be planted closer; place a shovelful of manure or a handful of good phosphate in each; five or six

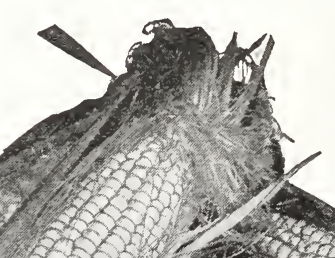

grains to a hill is sufficient; when up, thin them out, a1lowing three of the strongest plants to remain; thorough cultivation is necessary to secure a good crop. A quart will plant 100 hills; or eight quarts to the acre.

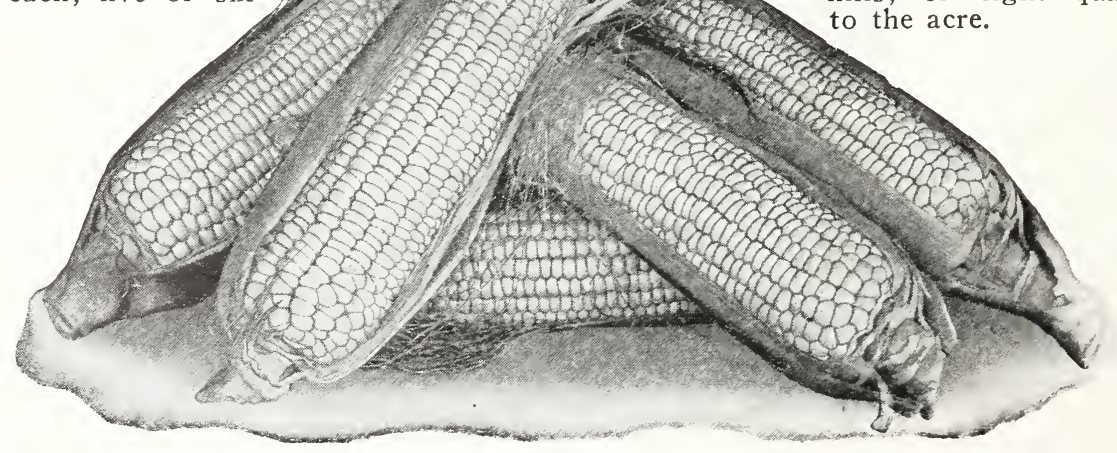

Stowell's Evergreen Sugar Corn 


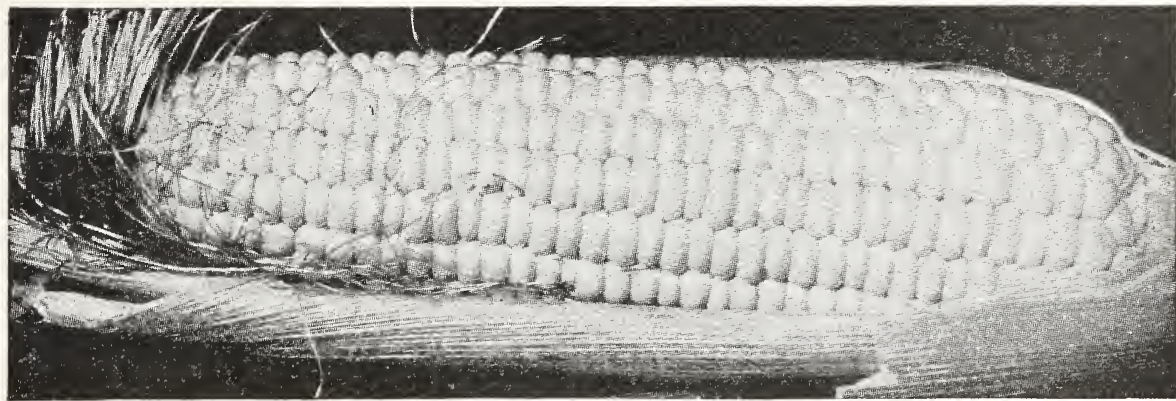

Golden Giant Sugar Corn

\section{GOLDEN BANTAM}

This corn with golden yellow grain has made a great reputation for its earliness and its delicious quality. It is one of the best for market and home use. The ears are eight rowed, 6 to 7 inches long and of the medium size that are most suitable for the table. The flavor is exceptionally rich and delicious. The stalks are 4 to 5 feet high; can be planted earlier than any other sugar corn. We recommend it highly. Pkt., 10c; 1/2 lb., 15c; 1 lb., 25c; 2 lbs., 45c; 10 lbs., \$2.00.

\section{BUIST'S GOLDEN GIANT}

Produces ears from 8 to 9 inches long with twelve to fourteen rows, and when in condi. tion for use, the grains are a deep creamy yellow in appearance. It matures about five days later than the Golden Bantam, and remains in a green and edible condition much longer; the flavor is exceptionally rich and delicious. We highly recommend this variety of Sweet Corn. Pkt., 10c; 1/2 lb., 20c; 1 lb., 30c; 2 lbs., 55c; 10 lbs., \$2.25.

\section{BUIST'S GOLDEN DAWN}

This new introduction is a week earlier than the Golden Bantam. The stalks are 4 to 5 feet high. The ears average $61 / 2$ inches long, with ten to twelve rows of bright golden grains, of sweet and delicious flavor. Especially desirable because of its extreme earliness. Pkt., 10c; 1/2 lb., 25c; 1 lb., 40c; 2 lbs., 70c; 10 lbs., \$3.00.

\section{NEW WONDER BANTAM}

Has all the fine qualities of the Golden Bantam but with larger ears. It is just as early and is more vigorous and productive. Grows 5 to 6 feet in height, bearing ears which measure 8 to 10 inches in length. Pkt., 10c; 1/2 lb., 20c; 1 lb., 30c; 2 lbs., 55c; 10 lbs., $\$ 2.40$.

\section{EARLY MINNESOTA}

Very early, of dwarf habit, ears of fair size, but of very choice quality. Pkt., 10c; $1 / 2 \mathrm{lb}$., 15c; 1 lb., 25c; 2 lbs., 45c; 10 lbs., $\$ 2.00$.
EARLY MAMMOTH WHITE CORY

Repeated and impartial tests not only of varieties already known, but also of new early varieties claiming to be as early or earlier than the Cory, have convinced us that the Cory is undoubtedly the earliest of all, and the very best extra early sweet Corn. The ears are twelve rowed, grains large, white and of ex. cellent quality. Pkt., 10c; 1/2 lb., 15c; $1 \mathrm{lb}$., 25c; 2 lbs., 45c; 10 lbs., \$2.00.

\section{WHIPPLE'S EARLY YELLOW}

A very profitable Corn to grow for market. Matures three days earlier than the Golden Bantam. The ears are 7 to 8 inches in length and of excellent quality. Pkt., 10c; 1/2 lb., 20c; 1 lb., 30c; 2 lbs., 55c; 10 lbs., \$2.25.

\section{WHIPPLES EARLY WHITE}

A fine early variety with deep grains like the Evergreen. Ears are 8 inches long with sixteen rows of fine sugary flavor. Pkt., 10c; $1 / 2$ lb., 20c; 1 lb., 30c; 2 lbs., 55c; 10 lbs., $\$ 2.25$.

\section{CROSBY'S EARLY}

A most excellent second early variety and largely grown in Maine for canning. It is of dwarf habit, produces medium-sized ears which have from ten to twelve rows; very productive and of luscious quality. Pkt., 10c; $1 / 2$ lb., 15c; 1 lb., 25c; 2 lbs., 45c; 10 lbs., $\$ 2.00$.

\section{STABLER'S EARLY}

A valuable second early Corn, remarkably large for so early a ripener. Yields an abundant crop, is desirable for family use and one of the most profitable for market; is sweet and delicious. Pkt., 10c; 1/2 1b., 15c; $1 \mathrm{lb}$., 25c; 2 lbs., 45c; 10 lbs., \$2.00.

\section{KENDALL'S EARLY GIANT}

A very fine early variety of excellent qual. ity; good-sized ears with twelve rows, suitable for market or private garden. Pkt., 10c; $1 / 2$ lb., 15c; 1 lb., 25c; 2 lbs., 45c; 10 lbs., $\$ 2.00$.

EARLY MAMMOTH SUGAR

A late ripening second early variety, producing ears of immense size, having from twelve to sixteen rows. Pkt., 10c; 1/2 1b., 15c; 1 lb., 25c; 2 lbs., 45c; 10 lbs., \$2.00. 


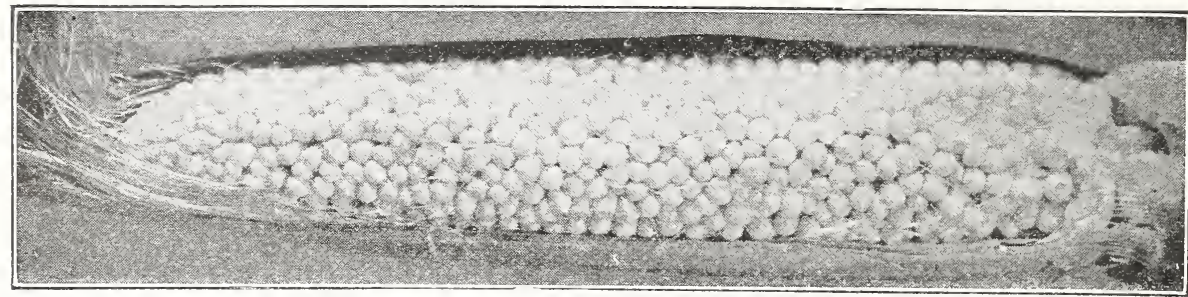

Country Gentleman Sugar Corn

Country Gentleman-This popular Shoe Peg Corn is especially recommended for canning and the home garden, as there is no variety that equals it for sweetness or delicacy of flavor. It is of dwarf growth, producing ears 7 to 8 inches long, with grains exceedingly deep and crowded irregularly on the cob. Pkt., 10 c.; $1 / 2$ lb., $15 c . ; 1$ lb., $25 c$.; 2 lbs., 45c.; 10 lbs., $\$ 2.00$.

Howling Mob-A fine Second Early Corn of delicious flavor. The stalks are about five feet in height and produce early in the season two splendid ears to the stalk. The name refers to the loud and clamorous demand for it when on sale in the markets. Pkt., 10c.; $1 / 2$ lb., 15c.; 1 lb., 25c.; 2. 1bs., 45c.; 10 lbs., \$2.00.

Early Evergreen-This variety resembles the Stowell's Evergreen, but is about ten days earlier. It is a splendid sort for the home and is grown extensively for market. Pkt., 10c.; $1 / 2$ 1b., 15c.; 1 lb., 25c.; 2 lbs., 45c.; 10 lbs., $\$ 2.00$.

Golden Evergreen-A cross between the Stowell's Evergreen and Golden Bantam, and combines the size of ear of the former with the rich golden yellow and delicious quality of the latter. Pkt., 10c.; $\mathrm{I} / 2$ lb., 15c.; 1 lb., 25c.; 2 lbs., 45c.; 10 lbs., $\$ 2.00$.

Late Mammoth-This variety produces the largest ears of any Sugar Corn, and is one of the best for market where size is required. It is of excellent quality, sweet, tender and delicious. Pkt., 10c.; $\mathrm{r} / 2$ lb., 15c.; 1 lb., 25c.; 2 lbs., 45c.; 10 lbs., $\$ 2.00$.

Long Island Beauty-A cross between the Stowell's Evergreen and Late Mammoth. It matures late and produces very large well-filled ears of excellent quality. A very profitable variety for the Market Gardener. Pkt., 10c.; I/2 1b., 15c.; 1 lb., 25c.; 2 lbs., 45c.; 10 lbs., $\$ 2.00$.

Black Mexican-This variety when young cooks white, but the dry seed is a bluish-black. It is unsurpassed for its delicious sweetness and fine quality and we highly recommend it to follow the first early varieties. The ears are 8 to 10 rowed, and about 8 inches long. Pkt., 10c.; 1/2 lb., 15c.; 1 lb., 25c.; 2 lbs., 45c.; 10 lbs., $\$ 2.00$.
Stowell's Evergreen Sugar-This is not only the most celebrated, but the most popular of all varieties, although not an early sort; it is, without any exception, the best for table use of the entire lot. although quite late. Some may observe they have tried it and find it not equal to the ordinary Sugar; to such we say, you have not had the pure stock, as no variety degenerates so quickly unless the grower is exceedingly careful. Our seed has been selected for its sweetness and large size. Pkt., 10c.; I/2 lb., 15c.; 1 lb., 25c.; 2 lbs., 45c.; 10 lbs., $\$ 2.00$.

White Evergreen-This variety is a little earlier than Stowell's and is pure white in color. The stalks are of strong, vigorous growth from six to seven feet high. The ears are very large and well filled to the tip with long, slender, pure white grains of the finest flavor. Pkt., 10c.; $1 / 2$ lb., 15c.; 1 lb., 25c.; 2 lbs., 45c.; 10 lbs., $\$ 2.00$.

Buist's First Early Table.-Those who follow trucking for market should not overlook planting this remarkable variety, although not classed among the varieties of Sugar, it is remarkably sweet and delicious. It is also very hardy, and can be planted earlier than any other variety with perfect safety; the ears average from seven to eight inches in length and have twelve rows. Pkt., 10c.; $\mathrm{r} / 2$ lb., $15 \mathrm{c}$.; 1 lb., $25 \mathrm{c}$.; 2 lbs., 45c.; 10 lbs., $\$ 2.00$.

Adams' Extra Early-This is the earliest of all, but it is not a Sugar Corn; is ready for the table in about six weeks after planting. It is not, by any means, a desirable variety further than for its earliness, as it lacks sweetness. Pkt., 10c.; 1 lb., 20c.; 2 lbs., 35c.; 10 lbs., $\$ 1.60$.

Adams' Early-A larger growing variety than Adams' Extra Early, but not as early. Pkt., 10c.; 1b., 20c.; 2 lbs., 35c.; 10 lbs., $\$ 1.60$.

Ideal Early-Not a Sugar Corn, very hardy and largely grown by market gardeners for the earliest crop. The ears are about eight inches long, twelve to fourteen rows. Pkt., 10c.; 1/2 1b., 15c.; 1 lb., 25c.; 2 lbs., 45c.; 10 lbs., $\$ 2.00$. 


\section{SELECTED FIELD CORN-Yellow Varieties}

\section{BUIST'S IMPROVED EARLY GOLDEN DENT}

The great advantage of the Improved Golden Dent over all other varieties is earliness, productiveness, beautiful ears, deep grain, small cob, and the superior quality of the meal which it makes. It was introduce 1 by us some years ago, especially for the Southern States, where it has become equally as popular as in. the North. It is very early and makes a fine quality of golden. colored meal. Those who desire to plant the best field corn should select it; the grains are very deep, cobs very thin and will shell more to a given weight of corn on the cob than any other variety; from sixty to eighty bushels can be grown per acre, according to quality of soil. 2 lbs., 25c; 7 lbs. (1/2 pk.), 65c; 14 lbs. (peck), $\$ 1.10 ; 56$ lbs. (bu.), \$3.50.

\section{IMPROVED EARLY LEAMING}

The Leaming is the earliest Yellow Dent Corn in cultivation, ripening in ninety to one hundred days from the time of planting; its extreme earliness, productiveness and fine quality have made it very popular with the farmers, and especially with those in the localities where the seasons are short. 2 lbs., 25c; 7 lbs. (1/2 pk.), 65c; 14 lbs. (peck), $\$ 1.10 ; 56$ lbs. (bu.), $\$ 3.50$.

\section{HUNDRED-DAY BRISTOL}

This is one of the earliest of the Large: Yellow Dent varieties, producing a large ear with broad grains, which are light yellow, tipped with a lighter shade; very popular with the farmers in New Jersey. 2 lbs., 25c; 7 lbs. (1/2 pk.), 65c; 14 lbs. (peck), $\$ 1.10 ; 56$ lbs. (bu.), $\$ 3.50$.

\section{LANCASTER COUNTY SURE CROP}

Grown very extensively in this section. The ears are about 14 inches long, with 14 rows of kernels. It is a good cropper and a very strong growing variety with plenty of foliage. Matures in 100 days. 2 lbs., 25c; 7 lbs. ( $1 / 2$ pk.), 65c; 14 lbs. (pk.), \$1.10; 56 lbs. (bu.), \$3.50.

\section{PENNSYLVANIA EARLY EIGHT-ROWED YELLOW}

One of the most valuable and productive varieties for late planting, producing very long ears, many measuring sixteen inches, and well filled out. It can be planted in this section as late as June 15 th to insure a crop. $2 \mathrm{lbs} ., 25 \mathrm{c}$; 7 lbs. ( $1 / 2$ pk.), 65c; 14 lbs. (peck), $\$ 1.10 ; 56$ lbs. (bu.), $\$ 3.50$.

\section{EARLY YELLOW CANADA}

Has eight rows and ripens very early; it is generally used with us for replanting. It is well adapted to sections where the season is short, or ground poor. 2 lbs., 25c; 7 lbs. ( $1 / 2 \mathrm{pk}$.), 65c; 14 lbs. (peck), $\$ 1.10 ; 56$ lbs. (bu.), $\$ 3.50$.

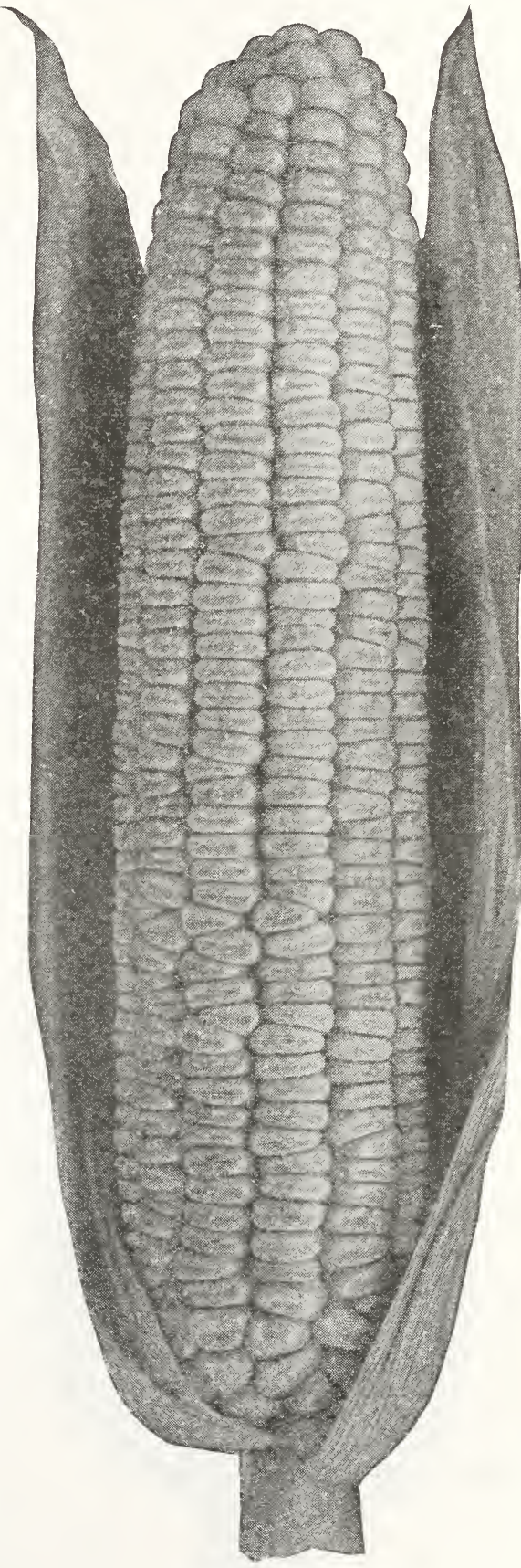

Truckers' Favorite Corn

If CORN.is wanted by MAIL, please add postage to cover COST of PARCEL POST. See zone rate on inside back cover page. 


\section{SELECTED FIELD CORN-White Varieties}

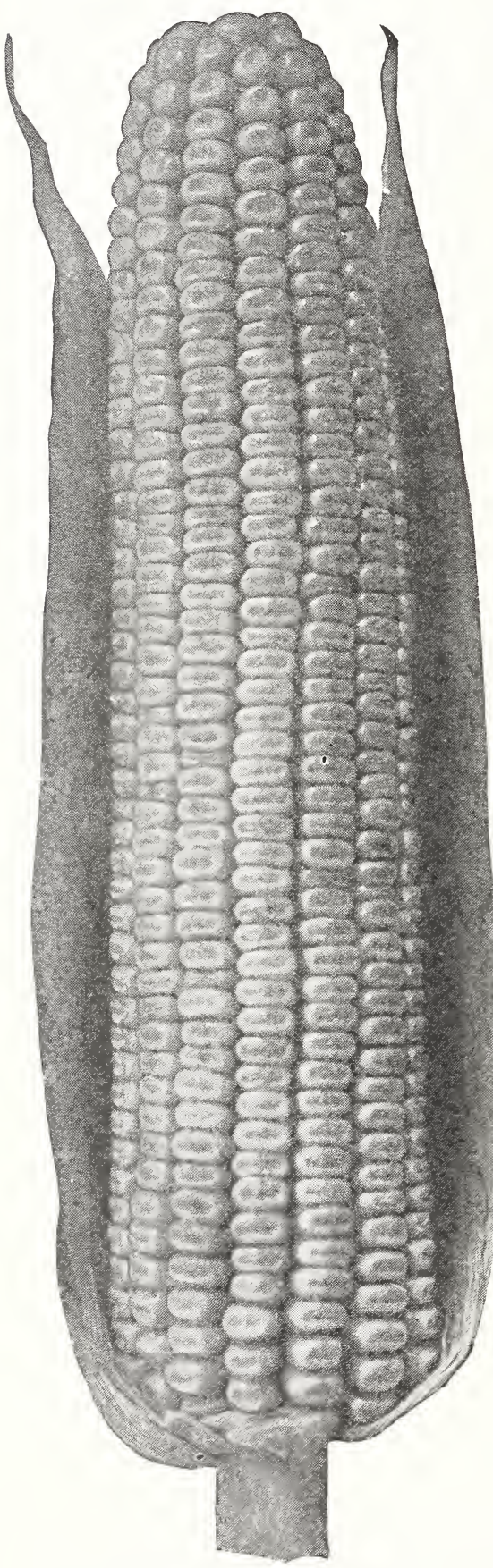

Buist's Prize Medal Snowflake Corn

\section{BUIST'S PRIZE MEDAL SNOWFLAKE}

In sections where white varieties of corn are preferred, the only kind that should be planted is the "Buist's Snowflake," as it has no equal for earliness, productiveness and fine quality. Our customers in the South write that they consider it far superior to any other variety, and find it especially adapted for that section. Its growth is from seven to eight feet, producing two ears to the stalk, which are very large. The cob is very thin and grains very deep. It matures in about 100 days, and will shell more corn from a given weight on the cob than any other white variety; it is also famous in the South for the fine quality of its roasting ears. 2 lbs., 25c; 7 lbs. (1/2 pk.), 65c; 14 lbs. (peck), \$1.10; 56 lbs. (bu.), $\$ 3.50$.

\section{TRUCKERS' FAVORITE}

For such markets as rank size and profit first, this variety is most desirable to grow for market as a Sugar Corn. The ears are twelve rowed, large and well filled, and when cut for market, the ears will average ten to twelve inches. It is a few days later than Adams Early and is also a splendid field corn for late planting, maturing in about 100 days. 2 lbs., 30c; 7 lbs., (1/2 pk.), 75c; $14 \mathrm{lbs}$. (peck), \$1.25; 56 lbs., (bu.), \$4.00.

\section{WHITE HICKORY KING}

The great feature of this variety is the large grain and small cob it produces. So large are the grains and so small the cob, that in an ear broken in half a single grain will almost cover the cob section; this can be done with no other variety. It is a vigorous grower, ears of fair size, ten rows, and grains pure white, and ripens in 115 to 125 days. A variety that can be depended on to produce a crop on poor, thin land. $2 \mathrm{lbs}$, 25c; 7 lbs. (1/2 pk.), 65c; 14 lbs. (peck), \$1.10; 56 lbs. (bu.), $\$ 3.50$.

\section{BLOUNT'S WHITE PROLIFIC}

A prolific white variety of flinty nature, mak ing excellent meal. It is of quick growth, producing from three to six ears to the stalk. Blount's Prolific also makes a first-class ensilage corn. 2 lbs., 25c; 7 lbs. ( $1 / 2$ pk.), 65c; 14 lbs. (peck), $\$ 1.10 ; 56$ lbs. (bu.), $\$ 3.50$.

\section{EUREKA ENSILAGE}

This corn originated in Virginia. It is pure white, medium hard, fine keeper and decidedly the best ensilage variety. It bears one to two ears to the stalk; the ears frequently measure 9 to 12 inches. It is tall and leafy, 12 to 15 feet high, with an enormous growth of fodder. 2 lbs., 25c; 7 lbs. (1/2 pk.), 65c; 14 lbs. (pk.), \$1.10; 56 lbs. (bu.), $\$ 3.50$.

\section{POP CORN WHITE RICE}

A popular variety. Pkt., 10c; lb., 25c; postpaid. Not prepaid, lb., 15c; 10 lbs., $\$ 1.25$.

GOLDEN QUEEN

Pops perfectly white. Pkt., 10c; lb., 30c; postpaid. Not prepaid, lb., 20c; 10 lbs., $\$ 1.60$. 


\section{CUCUMBER}

THE cucumber delights in rich, sandy loam. When the weather becomes warm, plant ten to twelve seeds per hill four feet apart each way. When the plants begin to crowd and all danger from the striped beetle is over, thin to three of the strongest plants per hill. Dust the plants as soon as they form their leaves with land plaster, tobacco dust or Slug Shot to protect them from bugs. Give frequent but shallow cultivation up to the time they begin to run. Pick the cucumber as soon as large enough to use, for if left to ripen, the plant soon stops bearing. In gathering, cut the stem instead of pulling the fruit to avoid injuring either vine or fruit.

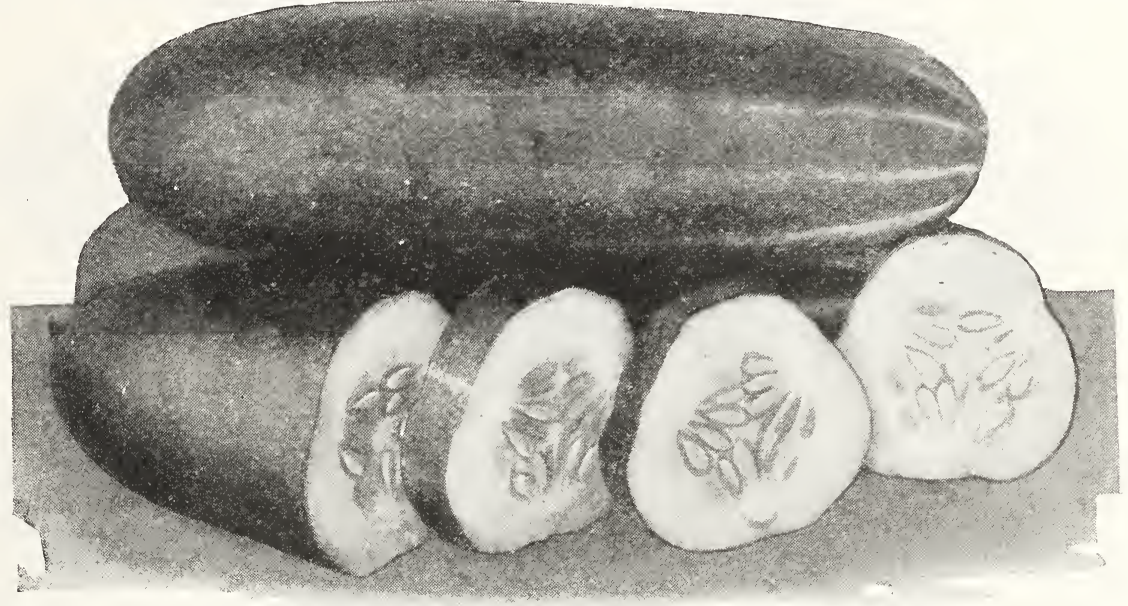

Buist's Special Dark Green Cucumber

\section{BUIST'S SPECIAL DARK GREEN}

This variety meets every demand for a first. class Cucumber for either the market gardener or the home garden. It is of a very attractive deep green color, which it retains when shipped a long distance. It is uniform in length, running from 8 to 10 inches, smooth in appearance, having very few white spines. The quality is superb, being exceedingly brittle and crisp, excellent for slicing, of a delicate flavor and free from any bitter taste. It is an early variety and immensely produc. tive. Pkt., 10c; oz., 15c; 1/4 lb., 50c; lb., $\$ 1.50$.

\section{THE DAVIS PERFECT}

One of the most attractives and popular of the newer varieties. The color-glossy dark green-is maintained almost up to maturity. It holds its color and apparent freshness long after being cut, rendering it a good shipping and market variety. It so resembles some of the forced or hot house cucumbers that it is often sold by fruit dealers as such and at high prices. The vines are such healthy, vigorous growers that they should not be planted nearer than 5 feet apart. It is very tender and of fine flavor. Pkt., 10c; oz., 15c; $1 / 4 \mathrm{lb}$., $50 \mathrm{c} ; \mathrm{lb} ., \$ 1.50$.

\section{ALWAYS GREEN}

A new strain of the White Spine. (It stays green.) It is of a very dark green color from stem to blossom end, which color it retains for a long period and is affected less by the hot sun than any other sort with which we are familiar; making it a very desirable shipping Cucumber. The form is so sym. metrical throughout the crops as to create comment wherever seen. Fruits are 6 to 8 inches long, cylindrical in shape, very uniform and bears a tremendous crop. Pkt., 10c; oz., 15c; 1/4 lb., 40c; lb., \$1.25.

\section{ARLINGTON, OR IMPROVED EARLY WHITE SPINE}

The Arlington White Spine is a selection made from the old variety and grown very extensively for forcing in the vicinity of Boston. It is equally as desirable for outdoor culture, but Buist's Perfection is far more desirable for either purpose, being of more perfect form, more productive, and retains its fresh green color longer. Pkt., 5c; 1/2 oz., 10c; oz., 15c; 1/4 lb., 40c; lb., \$1.25.

\section{THE KLONDIKE}

A medium early variety of White Spine, and very popular with market gardeners because of its productiveness and handsome dark green color. The vines are hardy and very prolific, fruit very uniform in size, excel. lent for slicing. It matures early, retaining its dark green color and crispness for a long time; our stock is of very superior strain. Pkt., 5c; 1/2 oz., 10c; oz., 15c; $1 / 4$ lb., 40c; lb., $\$ 1.25$. 


\section{BUIST'S PERFECTION EARLY WHITE SPINE CUCUMBER}

\section{THE GREAT MARKET GARDEN VARIETY SOLD ONLY UNDER OUR SEAL}

The Earliest, Finest Formed, Most Productive and Most Salable Variety to Grow for Market or Shipping, Retaining Its Color and Fresh Appearance Longer Than Any Other Variety

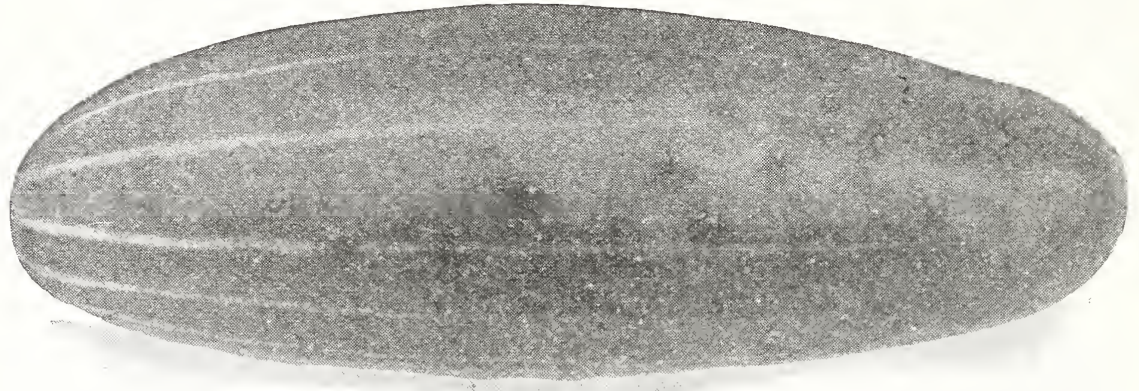

Buist's Perfection Early White Spine Cucumber

\section{BUIST'S PERFECTION EARLY WHITE SPINE}

A selection made from the Improved White Spine for its large size, perfection of form and earliness. As the earliest and most productive market variety it has no equal, and will be found far more profitable to grow than the Improved White Spine. Buist's Perfection is regarded by growers as the finest and purest stock known. It is not only the very earliest, but it produces cucumbers of the finest form and most salable size for shipping purposes. It was introduced by us a few years since, and is already being grown by the most ex. tensive cultivators and shippers of cucumbers in this country. It has become the most popular and salable stock of White Spine Cucumber Seed in this country. This variety is put up in our sealed packets-ounces, $1 / 4$, $1 / 2$ and 1 -pound cartons; we sell no seed in bulk; seed sold in any other way than in our sealed packages and cartons is not genuine. Pkt., 10c; oz., 15c; 1/4 lb., 50c; 1h., \$1.50; 5 lbs. at $\$ 1.40$.

\section{EARLY FORTUNE}

A popular variety with market gardeners and shippers in Texas and Florida; of the White Spine type. Color a rich dark green which holds for many days after picking. Stays plump and fine looking after reaching the Northern markets. Pkt., 5c; oz., 15c; 1/4 lb., 40c; lb., \$1.25.

\section{EARLIEST OF ALL}

A dark green White Spine, very early and productive and of especial value in localities where blight prevents the maturing of the late sorts. Pkt., 5c; 1/2 oz., 10c; oz., 15c; 1/4 lb., 40c; lb., \$1.25.

\section{NEW HYBRID SPINE}

The result of a cross between the White Spine and the English forcing cucumber, re. taining the fine beauty of the English sort and the hardiness of the White Spine. The fruits are much darker in color than other White Spine varieties, holding this color re. markably well. Very uniform in shape, with an average length of eight to ten inches. Pkt., 10c; oz., 15c; $1 / 4$ lb., 50c; lb., \$1.75.

\section{BUIST'S LONG GREEN}

A selection of the Long Green improved and developed by continued reselection. The vines are very vigorous and productive. Fruit very long, often twelve to fifteen inches, uni, form, slender and of a beautiful dark green color. They are often used for making sweet pickles. Pkt., 10c; oz., 20c; 1/4 lb., 50c; lb., $\$ 1.75$.

\section{EVERBEARING}

The peculiar merit of this recently introduced variety is that the vines continue to flower and produce fruit in every stage of growth until killed by frost. It is of small size, very early and enormously productive. Pkt., 5c; oz., 15c; 1/4 lb., 40c; lb., \$1.25.

\section{GREEN PROLIFIC, OR BOSTON PICKLING}

A splendid variety selected with great care by one of the largest growers of pickling cucumbers in the country. The vines are remarkably strong and very productive. The fruits are bright green, of medium size, very smooth and symmetrical. Pkt., 5c; 1/2 oz., 10c; oz., 15c; 1/4 lb., 35c; lb., \$1.10.

\section{COOL AND CRISP}

Extra early and very prolific, fine for slicing. Pkt., 10c; oz., 15c; 1/4 lb., 40c; lb., \$1.25. 


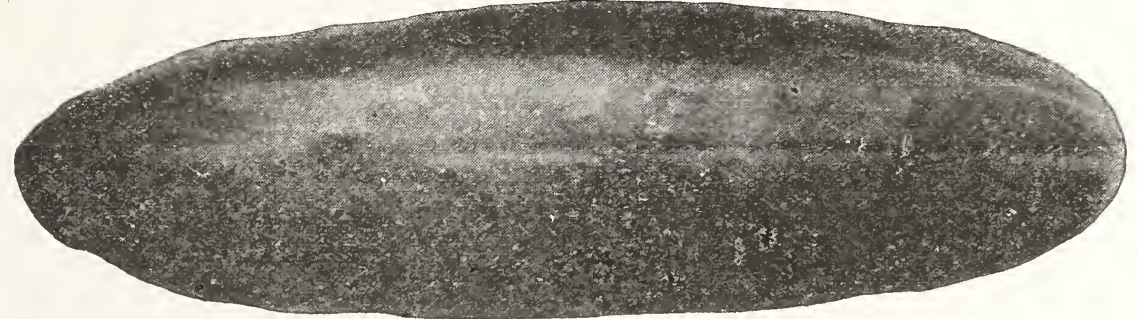

Davis Perfect Cucumber

\section{IMPROVED LONG GREEN}

The standard late sort. A very heavy cropper; the fruits are very long, often twelve to fourteen inches when mature. They are uniformly slender, tapering towards the stem and of a beautiful dark green color. The flesh is very firm and crisp and has a distinctive, fine flavor. It is the standard sort for slicing and is very largely used for pickles. Pkt., 5c; 1/2 oz., 10c; oz., 15c; 1/4 lb., 50c; lb., $\$ 1.50$.

\section{EARLY GREEN CLUSTER}

Is quite early and very productive; medium size and of a pale green color, turning to a brownish yellow when ripe. Produces the fruits in clusters, good quality and flavor. Pkt., 5c; 1/2 oz., 10c; oz., 15c; 1/4 lb., 40c; lb., \$1.25.

\section{EARLY FRAME OR SHORT GREEN}

Excellent both for table use and for pickling. Vigorous and productive. The fruits are straight, a little smaller at the ends, bright green in color. The flesh is crisp and tender. Pkt., 5c; 1/2 oz., 10c; oz., 15c; $1 / 4 \mathrm{lb}$., $40 \mathrm{c} ; 1 \mathrm{lb}$., \$1.25.

\section{JAPANESE CLIMBING}

The strong vines throwing out numerous tendrils can be trained upon a trellis or poles. The cucumbers are from twelve to sixteen inches in length. The flesh is pure white, crisp and of mild flavor. Pkt., 10c; oz., 15c; $1 / 4$ lb., 50c; lb., $\$ 1.50$.

\section{SNOW'S PICKLING}

An early maturing, very small, dark green cucumber, cylindrical, square ended, and very popular with growers of small pickles. Pkt., 5c; 1/2 oz., 10c; oz., 15c; 1/4 lb., 35c; lb., $\$ 1.10$.

\section{CHICAGO PICKLING}

This is a very productive variety extensively grown and used by pickling establishments. Medium length, pointed at each end, has large prominent black spines, color dark green. Pkt., 5c; 1/2 oz., 10c; oz., 15c; 1/4 lb., 35c; lb., \$1.10.

\section{JERSEY PICKLING}

This splendid variety is of uniform size, shape and color. The vines are vigorous. The fruits are deep green, of medium size, very smooth and symmetrical. The flesh is crisp and tender at all stages. Pkt., 5c; 1/2 oz., 10c.; oz., 15c; 1/1 lb., 35c; lb., \$1.10.

\section{WEST INDIAN GHERKIN, OR BURR}

Exclusively grown for pickling; it is the smallest of all varieties and should be picked while young and tender, and put in salt water until required for pickling. Pkt., 10c; oz., 20c; 1/4 lb., 50c; lb., \$1.50.

\section{ENGLISH FORCING CUCUMBER}

For forcing under glass, producing remark. ably long and very solid fruit with few and small seeds; considered by many a very great luxury. Splendid for growing in hot bed frames during the summer months. They can be started earlier and protected during cool nights, as they are more tender than the regular outdoor varieties. They may also be grown under glass in greenhouses during the winter, producing enormous fruits, generally 18 to 24 inches long and 3 inches in diameter.

\section{ROLLISON'S TELEGRAPH}

A standard greenhouse variety. Pkt., 25c or 5 Pkts., \$1.00.

\section{CRESS}

\section{CURLED OR PEPPER GRASS}

Extensively used as a small salad. Sow thickly in rows one foot apart. Frequent sowings should be made as it quickly runs to seed. Pkt., 5c; oz., 10c; 1/4 lb., 30c; lb., \$1.00.

\section{WATER CRESS}

Can be easily grown along the edges of shallow running streams. The leaves and stalks are used as a salad, and is considered a very wholesome dish. Pkt., 10c; 1/́2 oz., 25c; oz., 45c; 1/4 lb., $\$ 1.50$.

\section{DANDELION}

Sow early in the spring, in very warm, rich soil, in drills eighteen inches apart; thin the young plants to five inches in the row and cultivate well; they will be fit for cutting the next spring. One ounce will sow 100 feet of drill.

CULTIVATED, OR FRENCH COMMON

A decided improvement on the wild dande. lion. Very early and productive. Pkt., 10c; oz., 30c; 1/4 lb., 90c; lb., \$3.00.

\section{IMPROVED THICK LEAVED}

A selected variety, unsurpassed in thick. ness of leaf and deep green color. Pkt., 15c; 1/2 oz., 45c; oz., 80c; 14 lb., \$2.75; 1b., \$10.00. 


\section{EGG PLANT}

TO SEED is more difficult to vegetate than the Egg Plant; it always requires the strongest heat. For early use, sow in a hotbed early in Spring; after sowing, give them a good watering and keep the frame closed until the plants appear, then admit fresh air in fine weather; cover the frame at night with mats or straw to protect against frost; after the plants attain two or three inches they should be transplanted into another frame three inches apart. In order to make strong, healthy plants before it is time for planting out; it is a very good plan to plant them singly in small flowerpots, and place them in a frame where they will become thoroughly established and ready for setting out as soon as all cold weather is over, after which they can be planted from the pots without disturbing the roots. Plant them in rows twenty inches apart, and two feet from row to row; they luxuraite in rich, loamy soil.

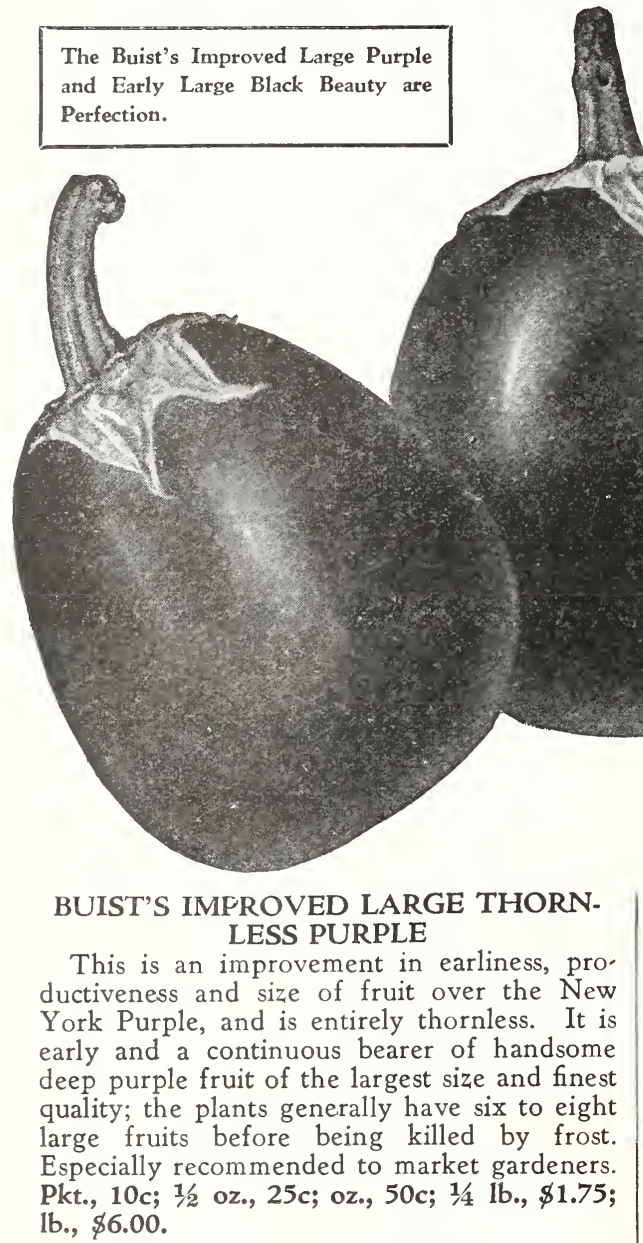

\section{EARLY LONG PURPLE}

The earliest of all. The fruits are 6 to 8 inches in length and about 3 inches in diameter. Color a dark purple. Pkt., 10c; 1/2 oz., 25c; oz., 45c; 1/4 lb., \$1.50; lb., \$5.00.

\section{NEW YORK IMPROVED PURPLE}

Fruit very large, oval shaped, with smooth stems; deep purple; of good quality. Very productive and of good size. Pkt., 10c; $1 / 2$ oz., 25c; oz., 45c; 1/4 lb., \$1.50; 1b., \$5.00.

Special attention is called to the Superior Quality of our Egg Plant Seed; there is no finer stock in this Country than we grow. 


\section{ENDIVE}

GOR a succession sow in very shallow drills from the beginning to the middle of Summer; - when the plants are up, thin them out to stand twelve inches apart; when the leaves have attained about eight inches long, they are fit for blanching; for this purpose a dry day must be selected. Gather the leaves up in your hand in a close and rounded form, observing there is no earth or litter in their center; tie them up closely to prevent the rain from penetrating, which would cause the heart to decay; in ten days or two weeks they will be blanched ready for use. For a Winter crop, transplant into frames during October and treat them in the same manner as the directions given for Lettuce.

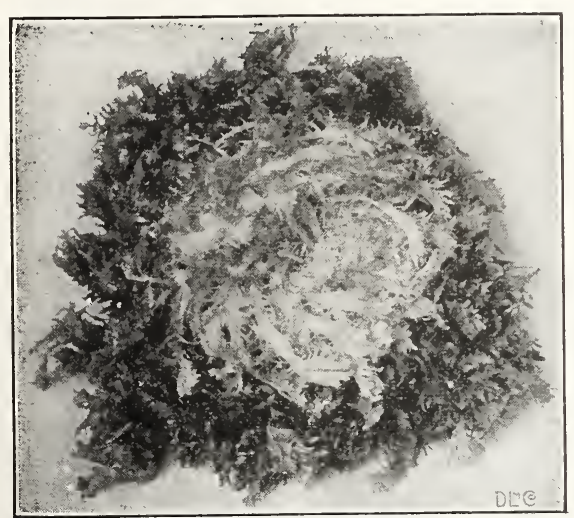

Green Curled Endive
Green Curled-The most popular variety, producing beautifully curled, tender, dark green leaves, and blanches cream white. Pkt., 10c; oz., 15c; 1/4 lb., 50c; lb., \$1.50.

White Curled-This resembles the green except in color, but is not quite as hardy; the foliage is light green, blanches white. Pkt., 10c; oz., 15c; 1/4 lb., 50c; lb., \$1.50.

Giant Fringed (Oyster Endive)-A strong growing variety with a large white heart and broad leaves, the heads frequently measure 15 inches in diameter. Pkt., 10c; oz., 15c; 1/4 lb., 50c; lb., \$1.50.

Batavian or Broad-Leaved-This variety forms large heads of broad, thick leaves, which are used for flavoring soups and stews; requires to be tied up for blanching. Pkt., $10 \mathrm{c} ;$ oz., 15c; 1/4 lb., 50c; lb., \$1.50.

\section{Kohl-Rabi, or Turnip-Rooted Cabbage}

This vegetable has always been a very great favorite with the European gardener, and is gradually gaining great popularity in this country. When young and tender, and properly prepared for the table, it is almost equal to Cauliflower; besides, it is a certain crop, requiring no more care or attention in cultivation than a crop of Cabbage. For an early crop sow in a hotbed early in Spring and treat the same as directions given for Early Cabbage; for a Fall crop, sow in June.

Early White Vienna-This variety is for garden culture and not for forcing; it is of dwarf habit, rapid growth and of delicate flavor; is ready for use when the bulb is about the size of an apple. Pkt., 10c; oz., 25c; $1 \frac{1}{1}$ lb., 75c; lb., $\$ 2.50$.

Early Short-Leaved White Vienna-This is the best variety for either forcing or outdoor culture; is exceedingly tender and delicate in flavor with very small leaves. Pkt., 10c; oz., 30 c; 14 lb., 90c; lb., $\$ 3.00$.

Early Purple Vienna-Similar to Early Short-Leaved White Vienna except in color; on that account is not so desirable. Pkt., 10c; oz., 25c; 1/4 lb., 90c; lb., \$2.75.

Large Green or White-These are coarse-growing varieties and more generally grown for feeding cattle; are not desirable for table use. Pkt., 10c; oz., 20c; 1/4 lb., 60c; lb., \$2.25.

\section{Fennel (Finocchio)}

A delicious vegetable which should be more largely grown in this country. It is extensively used in Italy as a salad, and also may be served boiled. Agreeable aromatic flavor, somewhat resembling celery, but with sweet taste and a more delicate odor.

Mammoth Messina-The "bulb" of this variety is oval and not flat like the Florence Fennel. Pkt., 10c; oz., 15c; 1/4 lb., 50c. lb., \$1.50.

Florence or Naples-Pkt., 10c; oz., 15c; 1/4 lb., 40c; lb., $\$ 1.25$.

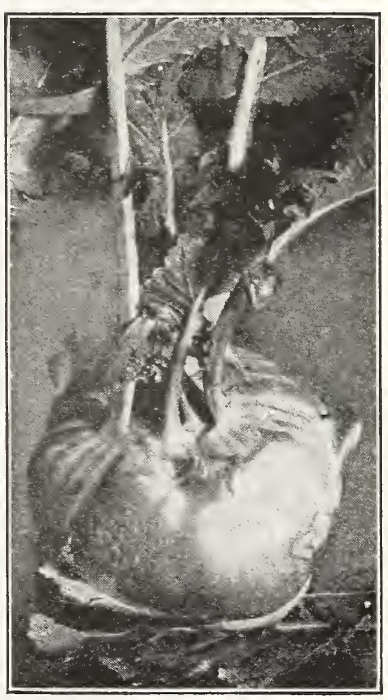

Kohl-Rabi 


\section{KALE or BORECOLE}

T ALE makes excellent "Greens" for Winter and Spring use. The leaves are boiled with 1 bacon the same as turnip tops and mustard. Sow seed $1 / 2$ inch deep in drills 2 feet apart and thin to 2 feet. apart in the row. Quality is improved rather than injured by frost. One ounce will sow 150 feet of drill; 3 pounds per acre.

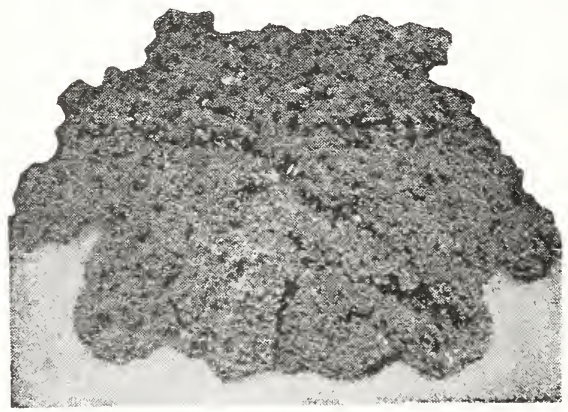

Dwarf Blue Scotch Kale

\section{DWARF GREEN CURLED SCOTCH}

Very dwarf and spreading; the leaves are very large, deeply curled, and of a desirable rich, bright green. The plant is of very dwarf growth, the leaves hugging the ground. We have a very excellent strain. Pkt., 5c; oz., 10c; 1/4 lb., 30c; lb., \$1.00.

\section{DWARF GERMAN GREENS}

Beautifully curled, bright green, very hardy, popular with market gardeners. This variety is hardy and the flavor is improved rather than harmed, by frost. Pkt., 5c; oz., $10 c ; 1 / 4$ lb., 30c; lb., \$1.00.

\section{CURLED SIBERIAN}

A very beautiful and valuable market variety; is quite hardy, a strong grower of dwarf habit, but not so finely curled as other varieties. Pkt., 5c; oz., 10c; 1/4 lb., 30c; lb., $90 \mathrm{c}$.

\section{DWARF BLUE CURLED SCOTCH}

Superior to the Green Curled Scotch, darker in color, very dwarf, the leaves hug. ging the ground. It is very hardy and will stand over the winter in any locality where the temperature does not go below zero. Pkt., 10c; oz., 15c; 1/4 lb., 40c; lb., \$1.25.

\section{FROST KING}

An extremely hardy variety, dwarf in habit, produces extra fine curled dark green leaves, tender and fine flavor. Will stand without injury the severest zero weather. Pkt., 10c; oz., 15c; 1/4 lb., 40c; lb., \$1.25.

\section{SPRING, OR SMOOTH KALE}

This variety thrives best when planted in the Fall for cutting during the Winter. It is very hardy, a rapid grower, tender, and sweet when young. Oz., 5c; 1/4 lb., 15c; lb. $40 \mathrm{c}$.

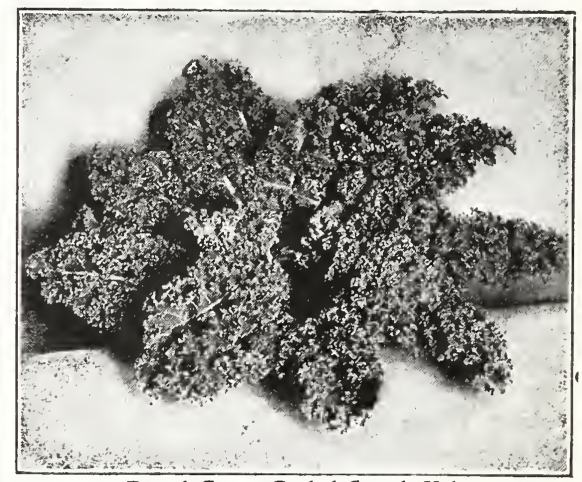

Dwarf Green Curled Scotch Kale

\section{LEEK}

R ELONGS to the onion family. Sow as early as the ground can be worked in spring in rows one foot apart. Cover seed about one inch deep. When plants are about six inches high, transplant in rows six inches apart; plant as deep as possible so that the neck being covered may be blanched.

\section{BUIST'S MAMMOTH}

A very large, vigorous growing variety; selected from the London Flag, especially adapted for market gardeners, producing the largest Leek known. Pkt., 10c; oz., 25c; $1 / 4 \mathrm{lb}$., 75c; lb., \$2.50.

\section{LARGE AMERICAN FLAG}

This is the ordinary variety, producing good-sized Leeks. Pkt., 5c; oz., 20c; 1/4 lb., $65 \mathrm{c} ; \mathrm{lb} ., \$ 2.25$.

\section{PRIZETAKER}

A fine, large variety, very mild and tender. The Leeks grow very long and thin and pure white in color. Its size and attractive appear. ance make it ideal for exhibition. Pkt., 10c; oz., 25c; 1/4 1b., 75c; lb., \$2.50.

\section{MUSSELBURGH}

An English variety of great merit, producing fan-shaped foliage; quite a strong grower, and a desirable market variety. Pkt., 10c; oz., 25c; 1/4 lb., $75 \mathrm{c} ; \mathrm{lb} ., \$ 2.50$.

\section{MONSTROUS CARENTAN}

A celebrated French variety of strong growth and very desirable. Pkt., 10c; oz., 25c; 1/4 lb., 75c; lb., $\$ 2.50$.

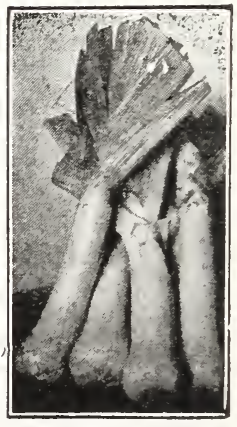

Leek 


\section{LETTUCE}

T ETTUCE is most tender and crisp when quickly grown, and thus requires a heavy, rich, 1 moist soil.

Sow outdoors as soon as ground can be worked, in drills 18 inches apart, $1 / 4$ inch deep and thin to 6 inches apart in the row. As they begin to crowd, thin out again and use as required. The larger heading varieties should not be closer than 12 inches in the row. Sow semi-monthly to September for a succession.

In the hot Summer months Lettuce is inclined to lose its crisp and tender qualities and is liable to run to seed. It can be successfully grown, however, even in the South, by soaking the seed in water one hour, and then placing in a piece of cloth in a cold place. Keep the cloth moist and when the seed is well germinated, sow broadcast and transplant when the proper size. Do this at evening, and water liberally. An artificial shading such as a screen of laths nailed to a light frame the width of the laths apart, and pegged about a foot above the bed, is excellent protection and will promote success in hot weather.

Lettuce seldom heads well in hot weather and should be used when young.

\section{BUIST'S SELECTED}

\section{BIG BOSTON}

Our strain of this very popular variety is un s u r p a s s ed. Thousands of acres of Big Boston Lettuce are grown annually in the South, the Market Gardeners of that sec. tion pronounce Buist's stock the best on the market. Plants a r e large and vigorous, leaves light $\mathrm{g}$ ree $\mathrm{n}$, slightly tinged with reddish brown; stands very long before shoot. ing to seed. Can be grown in the open ground in the Spring or Fall, or in frames for early Spring plant. ing, does particularly well in cold weather and is especially recom. mended for Fall plant. ing in the South. Is very popular with gar. deners and truckers,

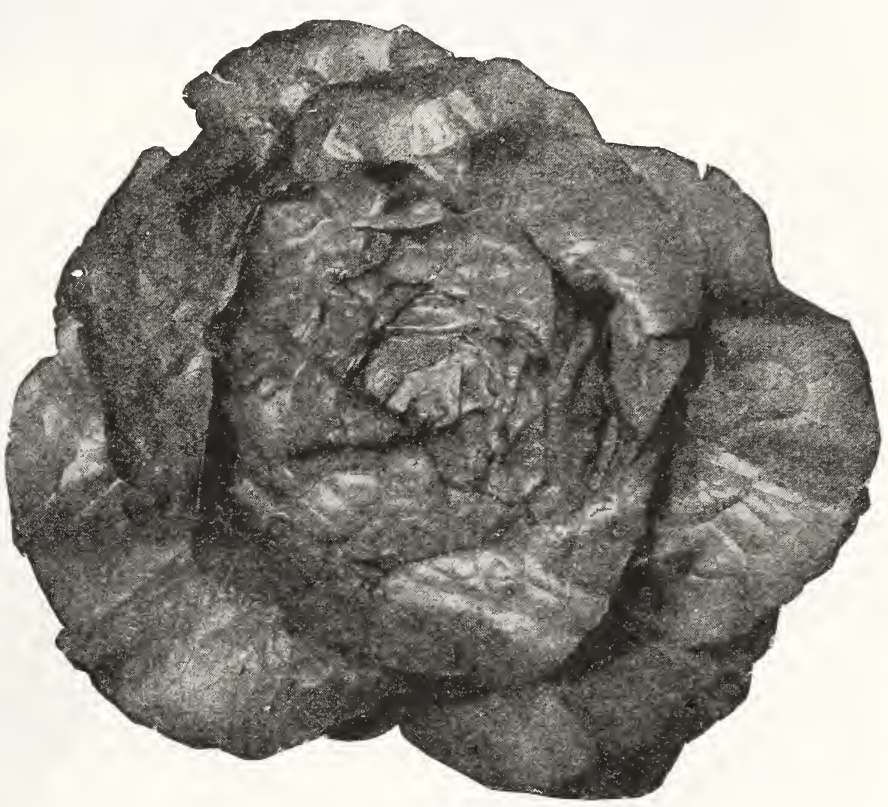

Buist's Selected Improved Big Boston Lettuce

because it always produces large, solid, salable heads; and with private growers because it heads up at all seasons and is of crisp and tender quality. Pkt., 10c; oz., 15c; 1/4 lb., 50c; lb., \$1.75.

\section{BUIST'S WHITE BIG BOSTON}

The head is very large, solid and of ex. cellent quality, the outer leaves are not very large and are light green, well crumpled, remarkable for its quick growth, forming heads ten days ahead of the Big Boston, to which its general character is very similar, except that the color is light green, and not tinged with brown. Stands cold weather; as a good gen. eral all-around lettuce none can compare with it; highly recommended to the market gardener. Pkt., 10c; oz., 20c; 1/4 lb., 60c; lb., $\$ 2.00$.

MAY KING LETTUCE

An unequaled variety for early Spring planting in the open ground, forming fine hard heads; it is of medium size, light green with buttery, but crisp heads; being of rapid growth and quick heading, we recom. mend it for the home as well as market gardening. Pkt., 10c; oz., 15c; 1/4 lb., 50c; lb., $\$ 1.50$.

\section{BLACK SEEDED BIG BOSTON}

A beautiful strain of the celebrated Big Boston, and cannot be recommended too highly. Heads are larger than Big Boston, leaves of a lighter shade of green. Pkt., 10c; oz., 15c; 1/4 lb., 50c; 1b., $\$ 1.50$.

\section{GRAND RAPIDS}

A very popular variety which is grown extensively for forcing and is also a home garden favorite. The plant forms a cluster of light green leaves, savoyed, finely crimped at edge, crisp and tender. Pkt., 10c; 0z., 15c; $1 / 4 \mathrm{lb}$., 5.0c; lb., \$1.50. 


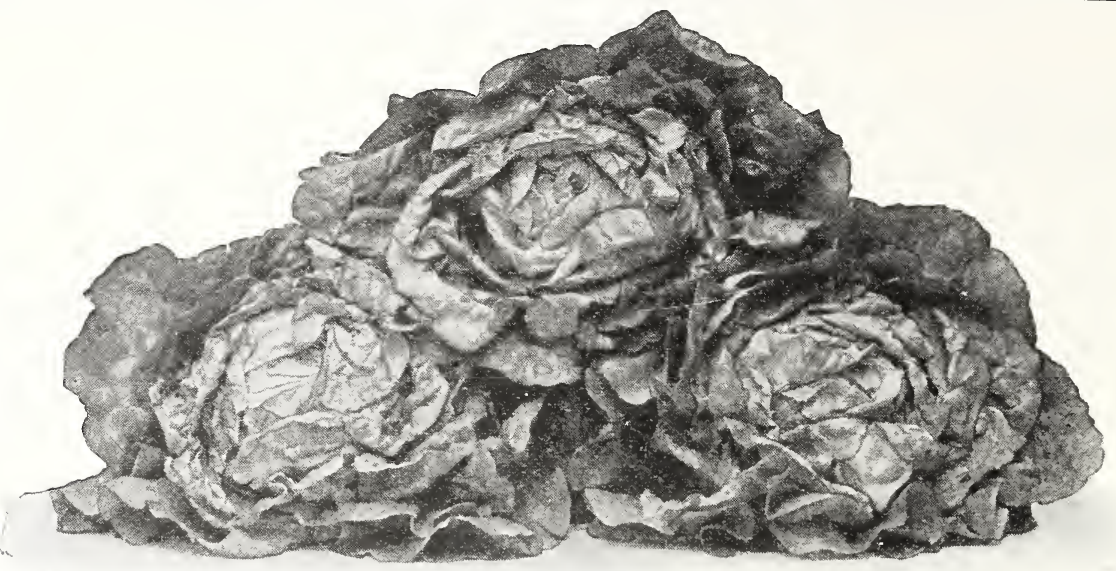

Buist's "Veribest" Cabbage Head Lettuce

\section{BUIST'S "VERIBEST" CABBAGE HEAD}

This is without doubt the best early cab. bage lettuce on the market, and is unsurpassed for general home use or market gardening, either for forcing or sowing in the open ground early in the season. It forms a beautiful solid head, which is very crisp and tender; outer leaves light green, with beautiful crumpled yellow inside leaves; of a rich but. tery flavor, absolutely free from any bitter. ness and will not turn red from cold. It can be sown broadcast in September and trans. planted in cold frames to cut early in the Spring. It is an excellent shipper and a good keeper. Pkt., 10c; oz., 20c; 1/4 lb., 60c; lb., $\$ 2.00$.

\section{UNRIVALLED}

A light green strain of Big Boston, but earlier, forming very large, solid heads with no red or bronze shading on the leaves. Heads are large, solid, crisp and tender. Pkt., 10 c; oz., 20c; 1/4 lb., 60c; lb., \$2.00.

\section{ICEBERG}

An excellent variety to plant throughout the season, producing large solid heads, always crisp and tender. The outer leaves are light green, curly and fringed closely, overlapping so that the inner ones are very finely blanched. As a good all-season lettuce, it is one of the best and we recommend it as a good sort for home or market. Pkt., 10c; oz., 15c; 1/4 lb., 50c; lb., \$1.75.

\section{EARLY DUTCH BUTTER}

A celebrated and entirely distinct variety, producing crisp, white, solid heads. The outer leaves tinged brown on the edges. Pkt., 10c; oz., 15c; 1/4 lb., 50c; 1b., \$1.75.

\section{IMPROVED EARLY HANSON}

A curled variety, forming fine, large, solid heads, which are both crisp and tender. They frequently attain two to three pounds each. A good heat-resisting variety. Pkt., 10c; oz., $15 \mathrm{c} ; 1 / 4 \mathrm{lb}$., 50c; 1b., $\$ 1.50$.

\section{NEW YORK, OR LOS ANGELES}

This variety produces heads of unusual size, frequently averaging 18 inches in diameter and weighing from three to four pounds, and almost as solid as cabbage; it blanches itself naturally, is crisp, tender and of excellent flavor, and always free from bitterness. This variety must not be confused with "Iceberg," which is the name used by some growers and shippers for the New York. Pkt., 10c; oz., 25c; 1/4 lb., 75c; 1b., \$2.50.

\section{BUIST'S NEW SENSATION}

An ideal Hot Weather Lettuce, withstands heat and drought better than any other sort. Heads are large, solid and handsome. Good for Spring, Summer or Autumn, plant is compact, forming a globular, firm, well. blanched head, color light green, never spotted or brownish in any part and always crisp and tender; quality excellent and buttery in flavor. Pkt., 10c; oz., 15c; 1/4 lb., 50c; lb., $\$ 1.75$.

\section{EARLY PRIZE HEAD}

One of the finest varieties ever introduced, forming a very large head, but not a solid one; the leaves are slightly tinged with brown, and is remarkable for its crispness and delicacy of flavor. Pkt., 5c; $1 / 2$ oz., 10c; oz., 15c; 1/4 lb., 50c; 1b., \$1.50.

\section{EARLIEST WAYAHEAD}

A very early variety of head lettuce that may be grown in the cold frame or open ground early in the Spring. Forms a very hard, compact head. Pkt., 10c; oz., 15c; $1 / 4$ lb., 50c; 1b., \$1.50.

\section{LARGE SALAMANDER}

A desirable variety for Summer or Fall use, forming very large, compact heads. Color light green; stands both heat and drought remarkably well; very highly recommended; it is undoubtedly the best Summer variety. The heads will average from two to three pounds. Pkt., 5c; 1/2 oz., 10c; oz., 15c; 14 lb., 50c; lb., \$1.50. 


\section{EARLY CURLED SIMPSON}

An improved variety of the Curled Silesia; is quite early; but does not produce a solid head; leaves beautifully curled and forces well. Pkt., 5c; 1/2 oz., 10c; oz., 15c; 1/4 lb., 50c; lb., $\$ 1.50$.

\section{BLACK-SEEDED SIMPSON}

A very desirable variety of the Curled Simpson. Does not produce a solid head, but a compact mass of leaves. It is not only a good forcing variety, but a desirable sort for early Summer, as it stands the heat remark. ably well. Pkt., 5c; 1/2 oz., 10c; oz., 15c; 1/4 lb., 50 c; lb., $\$ 1.50$.

\section{EARLY CURLED SILESIA}

An early variety, generally sown thickly to cut when a few inches high; it will, how. ever, form a very good head if thinned out; it is quite hardy and withstands heat and drought. Pkt., 5c; 1/2 oz., 10c; oz., 15c; 14 lb., 50c; lb., \$1.50.

\section{THE MORSE}

Each plant makes a large bunch of beautifully wrinkled leaves of brilliant green color; a most excellent variety, both for early Spring and Summer use. Pkt., 5c; 1/2 oz., 10c; oz., $15 \mathrm{c} ; 1 / 4 \mathrm{lb}$., 50c; lb., \$1.50.

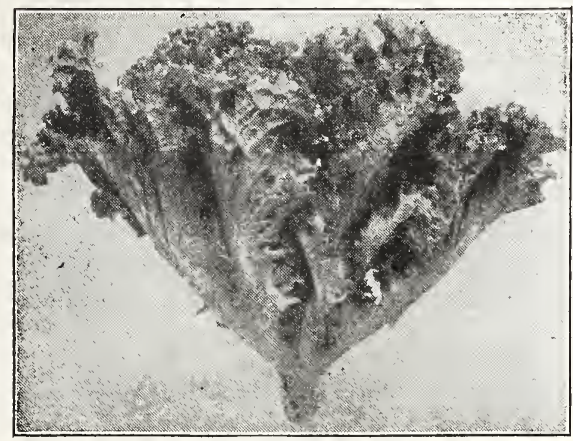

Grand Rapids Lettuce

\section{ALL HEART}

One of the few varieties that will head during hot weather, similar in shape and habit to the Salamander. It forms a good-sized, compact head, beautiful yellowish green in color, and has all the rich flavor of the Butter Lettuce. Pkt., 1.0c; oz., 15c; 1/4 lb., 50c; lb., $\$ 1.50$.

\section{HUBBARD'S MARKET}

A very celebrated and desirable variety of the Salamander type, forming large and compact heads. It will stand extreme heat and is slow shooting to seed. A splendid cabbage lettuce for the South. Pkt., 5c; 1/2 oz., 10c; oz., 15c; 1/4 1b., 50c; 1b., \$1.50.

\section{CHICKEN LETTUCE}

Distinct from any other Lettuce and will yield more chicken feed than any other plant grown for greens. The leaves can be pulled like Kale, after cutting it keeps on growing. Height 3 to 4 feet. Pkt., 5c; 1/2 oz., 10c; oz., $15 \mathrm{c} ; 1 / 4 \mathrm{lb}$., 50c; lb., \$1.50.

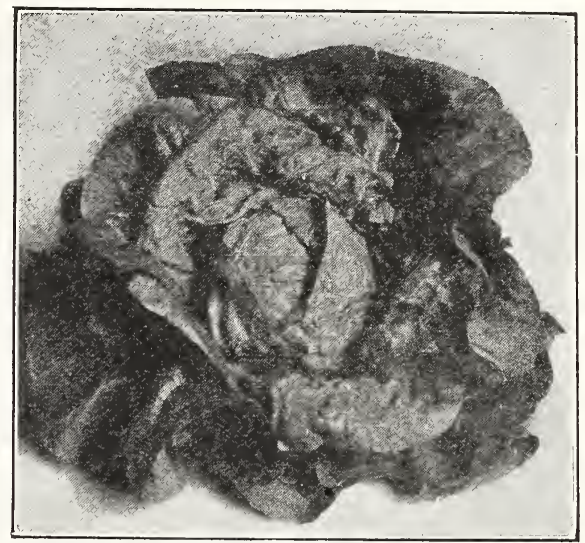

May King Lettuce

CALIFORNIA CREAM BUTTER

One of the best all-around Summer Lettuce; the heads are of a good size, compact and well formed; they have a rich, buttery flavor. Pkt., 5c; 1/2 oz., 10c; oz., 15c; 1/4 lb., 50c; lb., \$1.50. MIGNONETTE

A solid header; leaves broad in shape; ex. cessively blistered, crumpled and twisted. Quality excellent, tender, crisp and sweet. Pkt., 10c; oz., 20c; 1/4 lb., 60c; lb., $\$ 2.00$.

BLACK SEEDED TENNIS BALL

One of the best for forcing or early outdoor planting. When grown, forms solid heads, which are crisp and tender. Pkt., 5c; 1/2 oz., 10c; oz., 15c; 1/4 lb., 50c; lb., \$1.50. WHITE PARIS COS

Romaine or Celery Lettuce-This variety grows strong and upright, producing long leaves, which should be tied up and blanched before cutting, which makes them very crisp and tender. The entire plant is tender and edible. Pkt., 10c; oz., 20c; 1/4 lb., 60c; lb., $\$ 2.00$.

\section{TRIANON COS}

Similar to above, but grows whiter and matures earlier. Pkt., 10c; oz., 20c; 1/4 lb., $60 \mathrm{c} ; \mathrm{lb} ., \$ 2.00$.

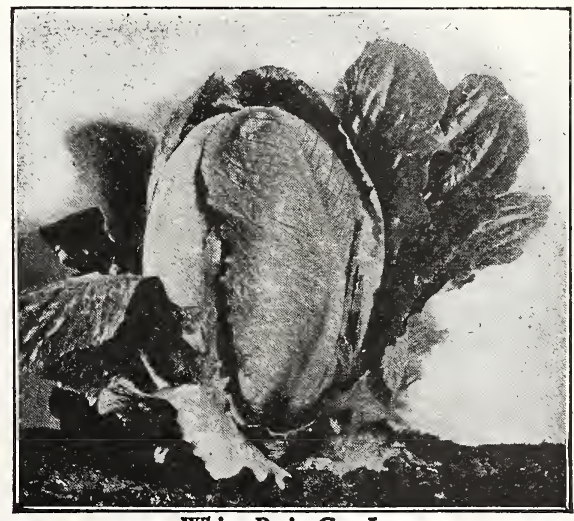

White Paris Cos Lettuce 


\section{MELON (Musk or Cantaloupe)}

THE MELON requires warm loam, well cultivated and enriched with manure or fertilizer. L Sow about eight seeds $3 / 4$ inch deep in raised hills 4 feet apart each way, and thin to the three strongest seedlings. Shallow cultivation is necessary, as it is important that roots are not disturbed. When thinning, cut off the surplus plants just below the surface, instead of pulling them. When 1 foot long, pinch off the points of shoots, to throw increased strength into the roots. Do not sow until all danger of frost is past, as the melons delight in a warm dry atmosphere.

Attacks of the striped beetle should be met by a dusting of fine soil, soot, or wood ashes. To prevent blight, spray with Bordeaux Mixture every ten days, after the plants have attained five or six leaves, adding Arsenate of Lead for eating insects.

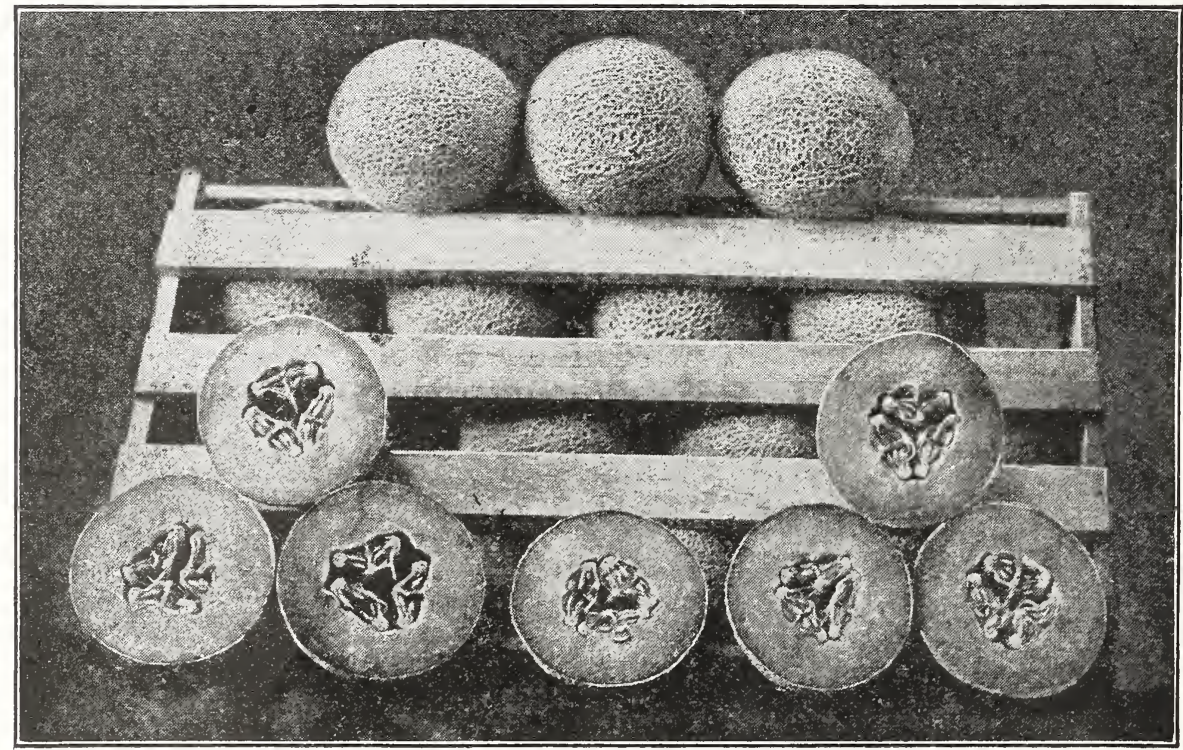

Buist's Perfection Rocky Ford Melon

\section{ROCKY FORD (BUIST'S PERFECTION)}

The Rocky Ford is the famous Netted Gem, introduced from Pennsylvania to Colorado, and in the dry atmosphere of the latter State attains perfection, so that it has become fam. ous as a shipping variety and is now more generally known as the Rocky Ford. Buist's Perfection is a specially selected strain, grown exclusively for us in Colorado, and is abso. lutely the choicest stock obtainable; form almost round and completely netted, flesh green, tinged with gold next to seed cavity; of fine flavor. Pkt., 10c; oz., 15c; 1/4 lb., 50c; lb., $\$ 1.50$.

\section{POLLOCK 10-25}

A very popular melon of the Rocky Ford type among Colorado growers, because of its resistance to both blight and rust. Very early, of the solid netted type that is so very desirable. Very small seed cavity, with thick luscious golden flesh shading to green near the rind. Pkt., 10c; oz., 15c; $1 / 4$ lb., 50c; lb., $\$ 1.50$.

\section{HALE'S BEST}

This new variety originated in the Imperial Valley of California. It is a remarkably early melon of fine flavor and the earliest of the Rocky Ford Cantaloupes. The rich salmon flesh is exceptionally thick and of a sweet, luscious and superb flavor. The fruits are oval and heavily netted, produced on vines of considerable hardiness. Seed cavity is small. Very popular with Colorado shippers, who recommend it highly. Pkt., 10c; oz., $15 \mathrm{c}$; 1/4 lb., 50c; lb., \$1.50.

\section{PINK QUEEN}

This delicious melon is one of the best salmon pink varieties. Is of strong growth, deeply netted and bred to resist disease and blight. Vines are vigorous and very produc. tive, shape slightly oblong, of medium size. The flesh is a deep rich salmon pink; very thick, fine grain and edible almost to the rind, of a delicious flavor. Highly recommended for market and home use. Seed cavity is small. Pkt., 10c; oz., 20c; 1/4 lb., 60c; lb., $\$ 2.00$. 


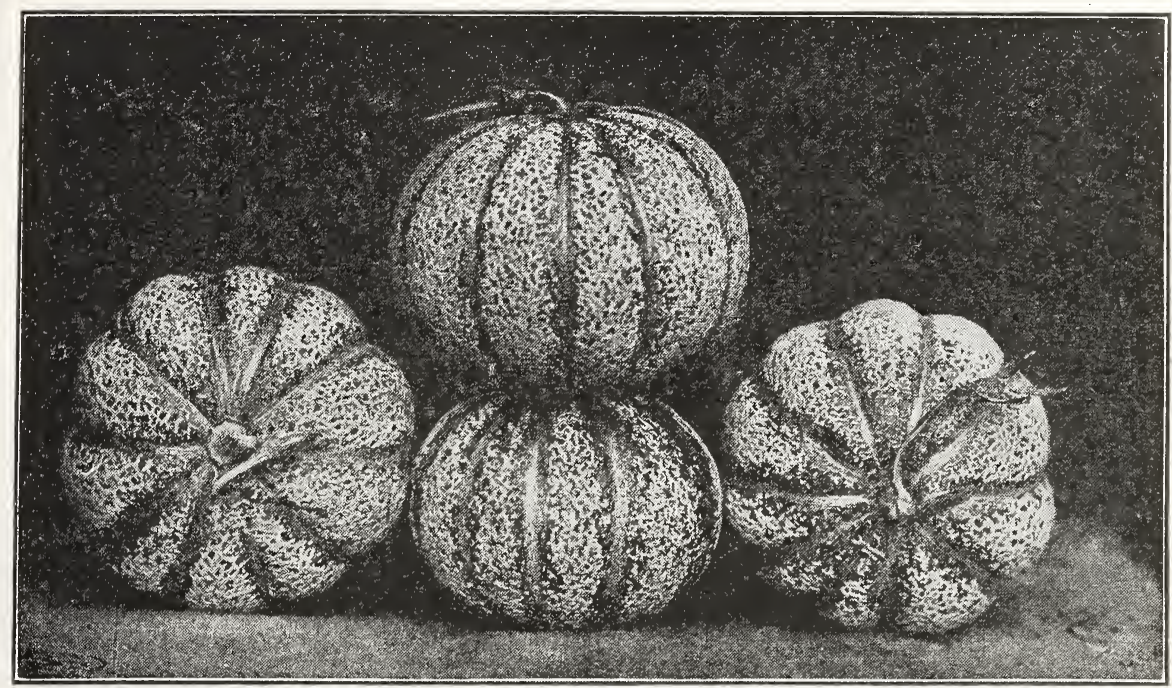

Fordhook Melon

\section{ROCKY FORD (BUIST'S SELECTED)}

This is a famous shipping variety. It is beautifully netted, of oblong shape; the skin is a rich greenish gold when ripe; rind thin, but very solid and firm; flesh green, slightly tinged with yellow. It differs from the Per, fection in its form and thickness of flesh, and its silver netting does not cover the melon so thoroughly. The strain we offer as Buist's Selected is of thoroughbred stock, and is saved from hand-selected fruit. Pkt., 10c; oz., 15c; $1 / 4 \mathrm{lb} ., 50 c$; lb., $\$ 1.50$.

\section{FORDHOOK}

A standard variety that is very popular in the Melon growing section of New Jersey. It is small, of flattened shape with broad ribs, deeply netted. The flesh is thick and firm, of a beautiful orange color and of delicious flavor. It can be relied on to produce a good crop of fruit even in unfavorable seasons. Pkt., 10c; oz., 15c; 1/4 lb., 5.0c; lb., \$1.50.

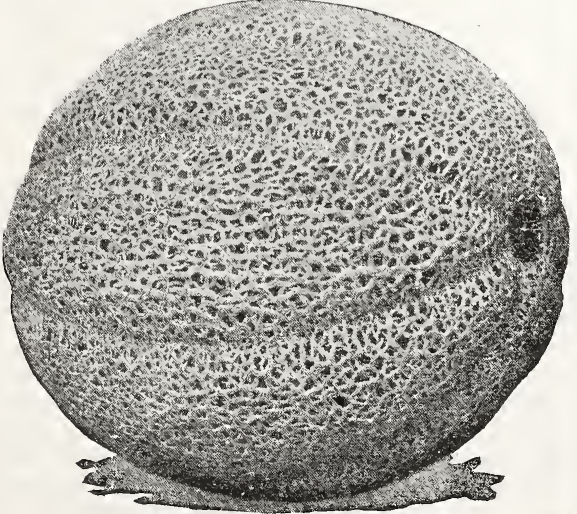

Knight or Sugar Sweet Melon
KNIGHT EARLY OR SUGAR SWEET

Ready for market fully ten days ahead of the Rocky Ford and larger in size. The vines are of strong, healthy growth, producing slightly oblong melons of regular form and size, deeply netted. The skin is light golden color, flesh bright green and ripening very close to the skin. It out-yields all other sorts, and we particularly recommend it to all market gardeners whose profits depend upon being first in the market. Pkt., 10c; oz., 15c; $1 / 4$ lb., 50c; lb., \$1.50.

\section{PEARL PINK MEAT}

A deeply netted Melon of exceptionally high quality with skin of a beautiful shade of pearl. Flesh is very thick and pink in color. The shipping qualities are excellent and they will command a premium over other varieties. Pkt., 10c; oz., 15c; 1/4 lb., 50c; lb., $\$ 1.50$.

\section{LAKE CHAMPLAIN}

A salmon-fleshed variety of extreme earliness, medium size and fine quality. A cross between the Fordhook and Emerald Gem, as it has a tendency to produce Melons resem. bling both types. Pkt., 10c; oz., 20c; 1/4 lb., $60 c ; 1$ lb., \$2.00.

\section{EMERALD GEM}

This is well named; it is really an emerald among the many varieties which are now cultivated; skin a dark green emerald color and quite smooth, flesh salmon, and of sweet and delicious flavor. Pkt., 10c; oz., 15c; 1/4 lb., 50c; lb., \$1.50.

\section{EDEN GEM, CR NETTED ROCK}

Highly esteemed on account of its rust, resisting qualities; is larger than the Rocky Ford, but not quite so early. Pkt., 10c; oz., 15c; 1/4 lb., 40c; lb., \$1.25. 


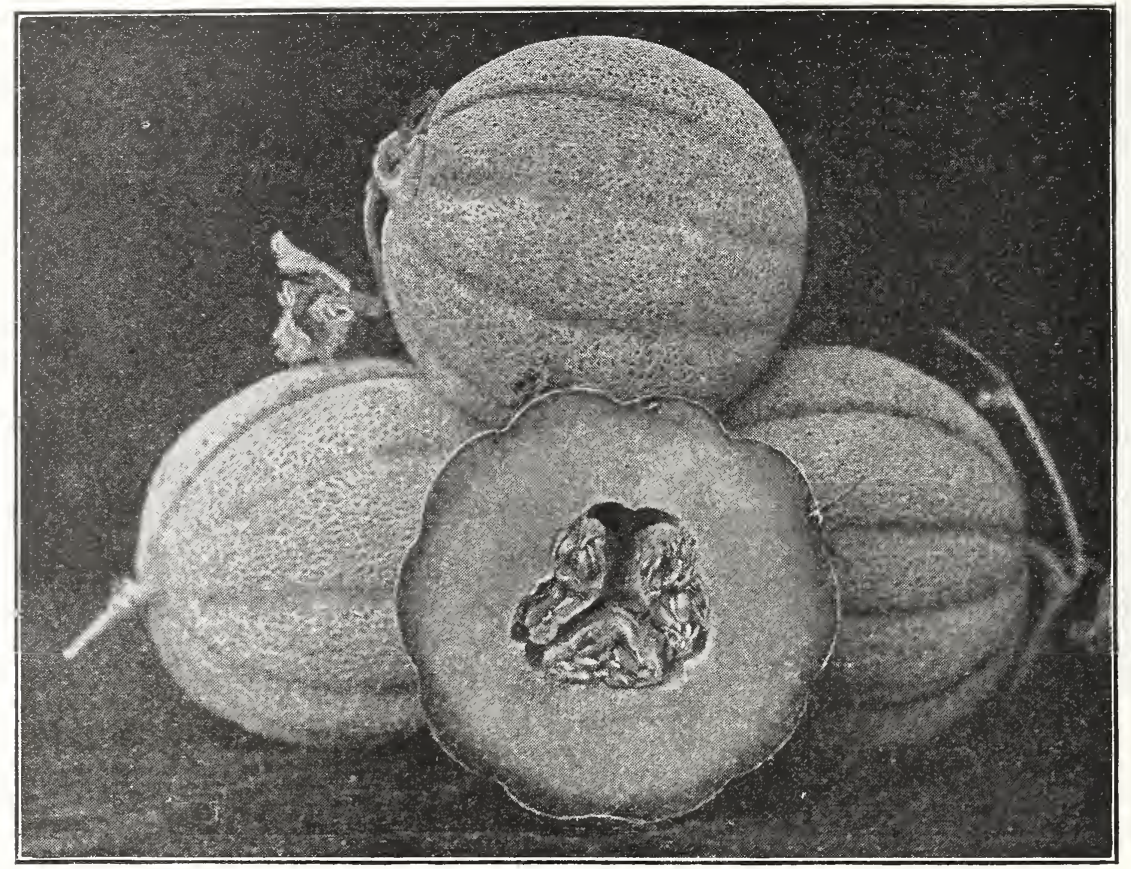

Hoodoo or Hearts of Gold Melon

HOODOO (HEARTS OF GOLD)

An ideal shipping melon of the very finest quality. Flesh rich orange color, very thick, firm and of delicious flavor. The seed cavity is small and the rind is very tough, making it a good shipper. The netting is exception. ally fine and dense, extending over the entire surface. Its vine is a vigorous grower and a heavy cropper. A good medium-sized melon for both home or market. Pkt., 10c; oz., 15c; $1 / 4$ lb., 50c; lb., \$1.50.

\section{EXTRA EARLY HACKENSACK}

Popular in many sections as a market melon and highly recommended for the home garden. It is two weeks earlier than the Large Hackensack. Of medium size, nearly round or somewhat flattened, broadly ribbed with very coarse netting. The flesh is green, very thick and delightful in flavor. Pkt., 10c; oz., $15 c$; 144 lb., 40c; lb., $\$ 1.25$.

\section{BANANA}

A long salmon-flesh variety, having the fragrance of the banana, and of fine flavor, growing from 20 to 24 inches long. Pkt., 10c; oz., 15c; 1/4 lb., 50c; lb., \$1.50.

\section{LARGE HACKENSACK}

A very popular variety also known as "Turk's Cap" which attains a large size, is round in shape and flattened at the ends; skin green and thickly netted; the flesh also is green, rich and sugary in flavor. It is very productive. Recommended for the home garden only. Pkt., 10c; oz., 15c; 1/4 lb., 40c; lb., \$1.25.

\section{HONEY DEW}

This fine melon is entirely distinct from any other variety and has taken front rank in popularity wherever used. Fruit of good size, weighing 6 to 8 pounds each, round to oval in shape. The smooth skin is a dull white when ripe, the flesh is crisp and delicious, very sweet and juicy, possessing the sweetness of honey and the freshness of the morning dew. The rind is thin but very firm, making it a good shipper. Not recommended for sections where the season is short. Pkt., 10c; oz., 20c; 1/4 lb., 60c; lb., \$2.00.

\section{HONEY BALL}

This new melon is a cross between the Honey Dew and a cantaloupe. It is very desirable for the home gardens because of its exceptional sweetness and is a money maker for the market gardener and shipper. It is early, very prolific and a good keeper. Pkt., $10 \mathrm{c}$; 1/ $\mathrm{k}$ oz, 15c; oz., 25c; 1/4 lb., 75c; lb., $\$ 2.50$.

\section{TIP TOP}

A yellow flesh melon of the highest quality. The fruits are large, nearly round and lightly netted. It is sweet, juicy, of finest flavor. A strong grower and heavy yielder. Pkt., 10c; oz., 15c; 1/4 lb., 50c; lb., \$1.50.

\section{BENDER'S SURPRISE}

A very popular variety in the East. It is a delicious melon with beautiful salmon flesh, large, oblong in shape. Matures early and has superior shipping and keeping qualities; and is an excellent home-growing variety. Pkt., 10c; 0z., 15c; 1/4 lb., 50c; lb., \$1.50. 


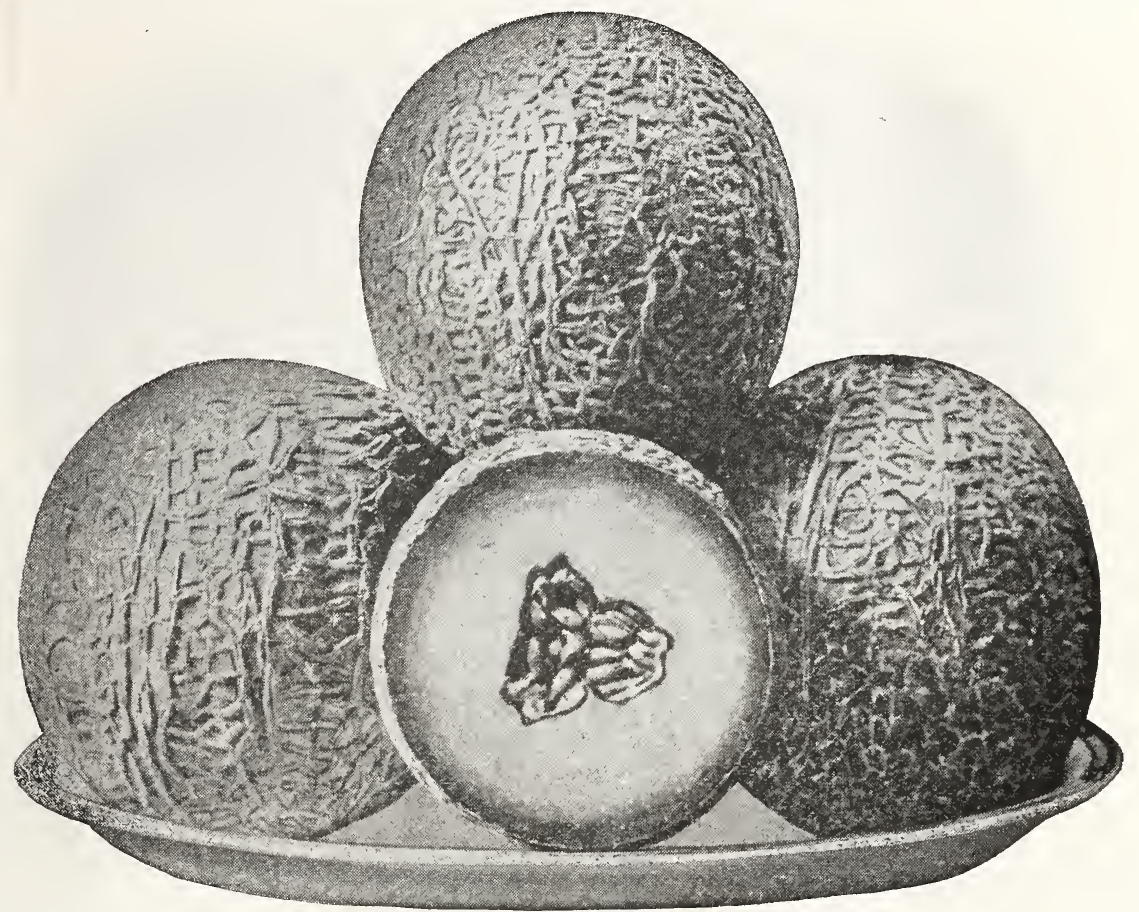

Sugar Rock Melon

\section{SUGAR ROCK}

Sugar Rock is one of the most prolific varieties grown. Five to seven perfect fruits are often produced on one vine. The rind is so tough and the flesh so firm that they can be allowed to ripen on the vine and shipped long distances. The appearance of Sugar Rock melons is strikingly attractive, and dis. tinct from all other sorts. The fruits are oval and heavily ribbed. Medium in size, and marvelously sweet. Pkt., 10c; 1/2 oz., 20c; oz., 3.0c; 14 lb., 90c; lb., \$3.00.

\section{EDWARDS PERFECTO}

The Perfecto melons have the smallest seed cavity and deeper colored flesh than any other type of Rocky Ford shipping melon. Flesh very thick and of a beautiful salmon color, shading to green as it nears the rind. Pkt., 10c; oz., $15 c ; 1 / 4$ lb., 50c; lb., \$1.50.

\section{BURRELL'S GEM}

A very popular variety of the salmon-flesh class, of medium size, oblong, sweet and delicious; a fine market variety. Pkt., 10c; oz., 15c; 1/4 lb., 50c; lb., \$1.50.

COSMOPOLITAN, OR CANNON BALL

Fruits of medium size, nearly round or slightly oval, without ribs. Color, light green, but becoming covered at maturity with dense, silver gray netting. The flesh is green, firm, sweet and uniformly high flavored. Pkt., 10c; oz., 15c; 1/4 lb., 50c; lb., \$1.50.

\section{OSAGE, OR MILLER'S CREAM}

This variety has secured a quick and won. derful reputation from its peculiar luscious, spicy flavor and good shipping qualities. It is of egg shape, skin very thin, of dark green color, remarkably sweet; very productive, a good keeper, and stands shipping. Pkt., 10c; oz., 15c; 14 lb., 50c; lb., \$1.50.

\section{EXTRA EARLY OSAGE}

An extra early strain of the old type Osage, nearly as large, ten days earlier and of equal quality. Flesh salmon colored, very thick, firm, sweet and highly flavored. Pkt., 10c; oz., 15c; 1/4 lb., 50c; lb., \$1.50.

MONTREAL MARKET, OR CANADIAN

Excellent variety of the largest size, weighing from ten to twenty pounds each. In shape almost round, flattened at the ends, deeply ribbed. Flesh green, very thick and of delicious flavor. Pkt., 10c; oz., 15c; 1/4 lb., 50c; lb., \$1.50.

\section{IMPROVED EARLY JENNY LIND}

The earliest of all varieties, possessing a rich and delightful flavor and fragrance; for quality and sweetness is unsurpassed by any other variety, and highly recommended. Pkt., 10c; oz., 15c; 1/4 lb., 50c; lb., \$1.50.

\section{LONG YELLOW CANTALOUPE}

The largest of the pink fleshed sorts. Long, oval and deeply ribbed, and is exceptionally sweet and thick. Pkt., 10c; oz., 20c; 1/4 lb., $60 \mathrm{c} ; \mathrm{lb} ., \$ 2.00$. 
WATERMELONS

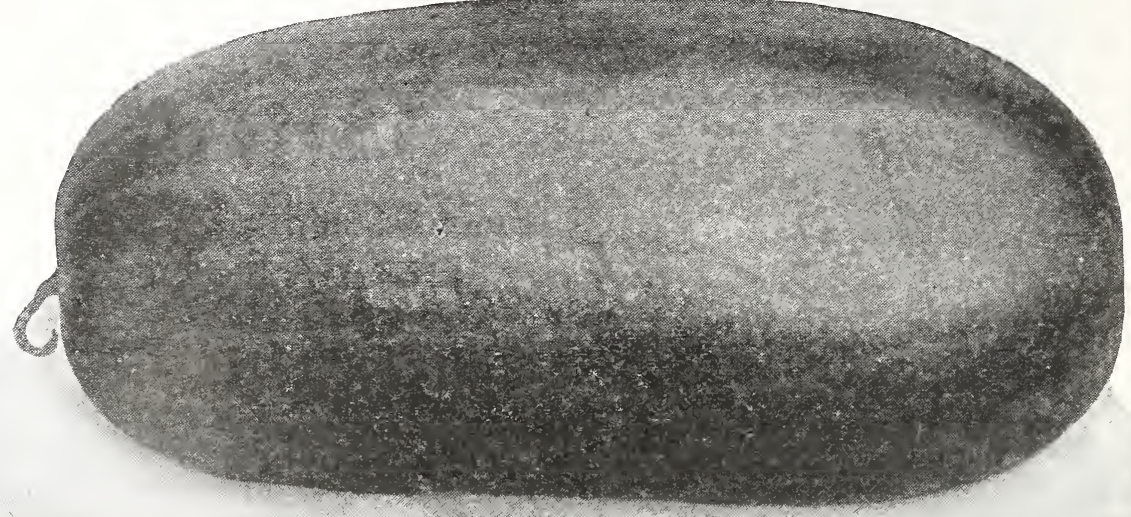

Tom Watson Watermelon

Tom Watson-Buist's Selected Stock. No melon ever introduced has sprung into popular favor so quickly as the Tom Watson; it is the watermelon of today and for the future, as it possesses all the fine qualities of a perfect variety, both as to its productiveness, quality and for transportation to distant markets without damage; its size ranges from eighteen to twenty-four inches long by ten to twelve inches in diameter, and weighing from forty to fifty pounds. Color dark green, deep red flesh, which extends close to the rind, free from core, crisp, melting and of the finest quality; it also commands the highest market prices. Strongly recommended. Pkt., 5c.; Oz., 10c.; I/4 1b., 30c.; 1b., $\$ 1.00$.

Kleckley Sweets - A general favorite with all lovers of sweet and luscious melons, and cannot be too highly recommended for either private gardens or for near markets; is oblong, of good size; skin dark, rich green and exceedingly thin and brittle; flesh bright scarlet; is crisp, sugary and melting, but will not stand long shipments. Pkt., 5c.; oz., 15c.; I/4 lb., 50c.; lb., \$1.50.

Halbert Honey-A large, oblong variety with dark, glossy, green skin, and regarded by many to be as sweet as Kleckley Sweets, which is a strong recommendation. Splendid for home use, but, like the Kleckley's, will not stand shipping long distance. These two varieties are superior in quality to any other sort, and highly recommended. Pkt., 5c.; oz., 15c.; I/4 1b., 40c.; lb., \$1.25.

Florida Favorite-This variety originated with one of the most extensive melon growers of Florida, and is a hybrid of the Rattlesnake and Pearson. It is of oblong shape and large size; rind dark with light green stripes; flesh light crimson, very crisp and sweet. Pkt., 5c.; oz., 15c.; I/4 1b., 40 c.; lb., \$1.25.

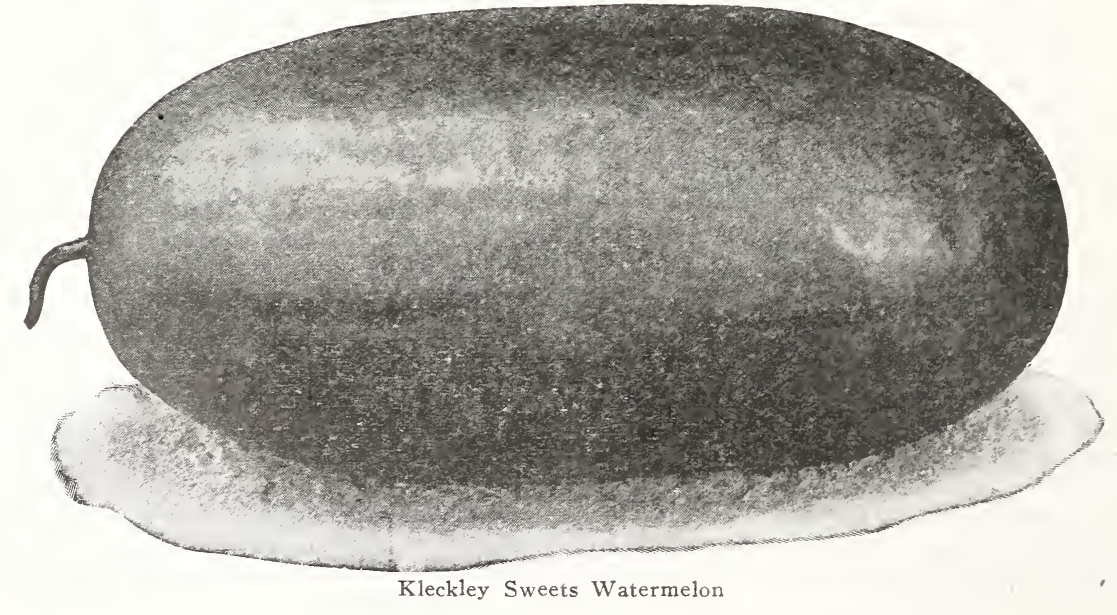




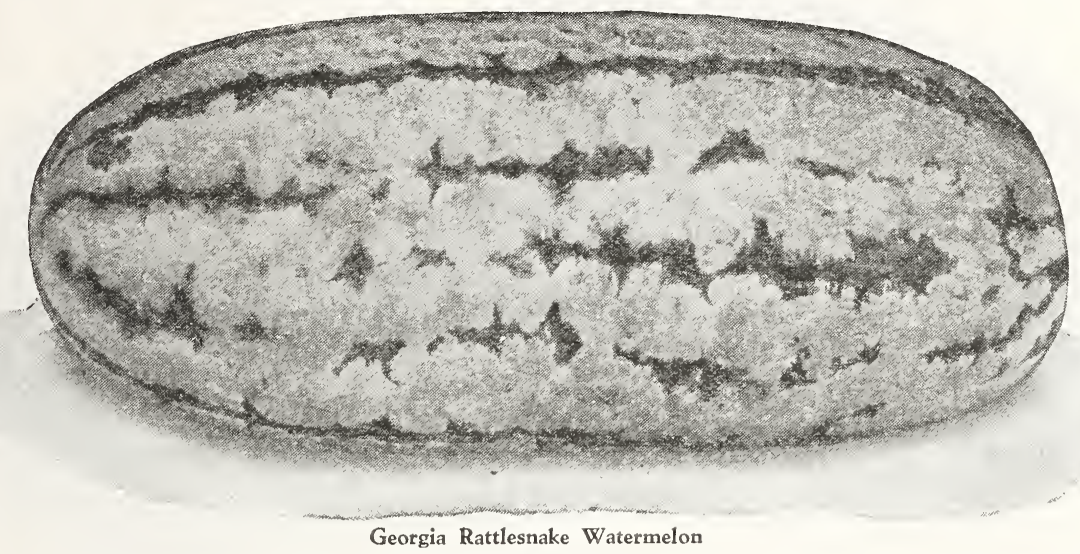

\section{STONE MOUNTAIN}

This new variety is strongly recommended for the home garden and nearby markets. Shape nearly round, rind dark green, flesh a bright red, crisp, sweet and very firm. It grows very large, weighing from fifty to eighty pounds at maturity on good melon ground. Ripens throughout. Pkt., 10c; oz., 15c; 1/4 lb., 50c; lb., \$1.50.

\section{GEORGIA RATTLESNAKE}

A variety which has gained great popular. ity throughout the entire country for its size and fine shipping qualities; shape oblong, of light green color, and beautifully mottled and striped with a lighter shade; flesh scarlet, rind thin, very solid, and both sweet and delicious. Pkt., 5c; 1/2 oz., 10c; oz., 15c; 1/4 lb., 40c; lb., $\$ 1.25$.

\section{THE DIXIE}

This variety, which originated in the South, we regard as one of the best for shipping or table use. Is of large size, scarlet flesh and exceedingly sweet and melting, oblong in form; skin dark green with stripes of lighter green. It is very prolific and frequently matures six to eight large melons to a vine. Pkt., 5c; oz., 10c; 14 lb., 30c; lb., \$1.00.

\section{MONTE CRISTO}

Very similar to Kleckley Sweets and especially recommended for private gardens where quality is of greatest importance. Fruit of large size, oblong, of dark green color, thin rind; flesh bright scarlet and of delicate flavor. Pkt., 5c; oz., 15c; 1/4 lb., 40c; lb., \$1.25.

\section{COLE'S EARLY}

This variety is a great favorite in the Northern States, and one of the finest for family use or the home market. Melons are medium size, shape oblong, thin brittle rind; flesh, rich red, delicious and sweet. Very early and productive. Pkt., 5c; oz., 10c; $1 / 4$ lb., 30c; lb., \$1.00.

\section{IRISH GRAY}

$A$ new and distinct variety producing more marketable melons per acre than any other sort. The flesh is a very bright rich red, exceedingly sweet and tender. Rind is thin but very tough, insuring good shipping qualities. Color of rind is a mottled greenish gray entirely distinct. Earlier than Tom Watson. Pkt., 5c; oz., 15c; 1/4 lb., 40c; lb., \$1.25.

\section{ALABAMA SWEET}

This very desirable variety is becoming more popular in localities where melons are grown for shipping. Form oblong, color dark rich green, with light green stripes; flesh, bright scarlet and quality fine. Pkt., 5c; oz., 10c; 1/4 lb., 30c; lb., $\$ 1.00$.

\section{BLUE GEM OR ICEBERG}

One of the most popular market and ship. ping varieties. It keeps well and seldom cracks or splits in transit, and produces melons of a uniform size. Pkt., 5c; oz., 10c; 1/4 lb., 30c; lb., $\$ 1.00$.

\section{SWEET-HEART}

An oval, light, green-skinned variety. mottled, with very thin rind, but quite firm and solid; flesh bright red, of delicious flavor. Pkt., 5c; oz., 10c; 1/4 lb., 30c; lb., \$1.00.

\section{CAROLINA BRADFORD}

A famous Southern variety which has gained quite a reputation for its fine quality; flesh dark crimson and remarkably sweet and luscious. Size large and oblong; rind dark green with darker stripes. Pkt., 5c; 1/2 oz., 10c; oz., 15c; 1/4 lb., 40c; lb., \$1.25.

\section{ICE CREAM}

This variety grows to a medium size; nearly oval, of a pale green color, and has a thinner rind than any other variety; flesh is bright crimson, crisp and of delicious flavor. Pkt., 5c; $1 / 2$ oz., 10c; oz., 15c; $1 / 4$ lb., 40c; lb., $\$ 1.25$.

\section{DARK ICING}

A very desirable variety. Dark skin, crim. son flesh, thin rind, quite solid and of a delicious flavor. A fine market sort. Pkt., 5c; $1 / 2$ oz., 10c; oz., 15c; 1/4 lb., 40c; lb., \$1.25. 


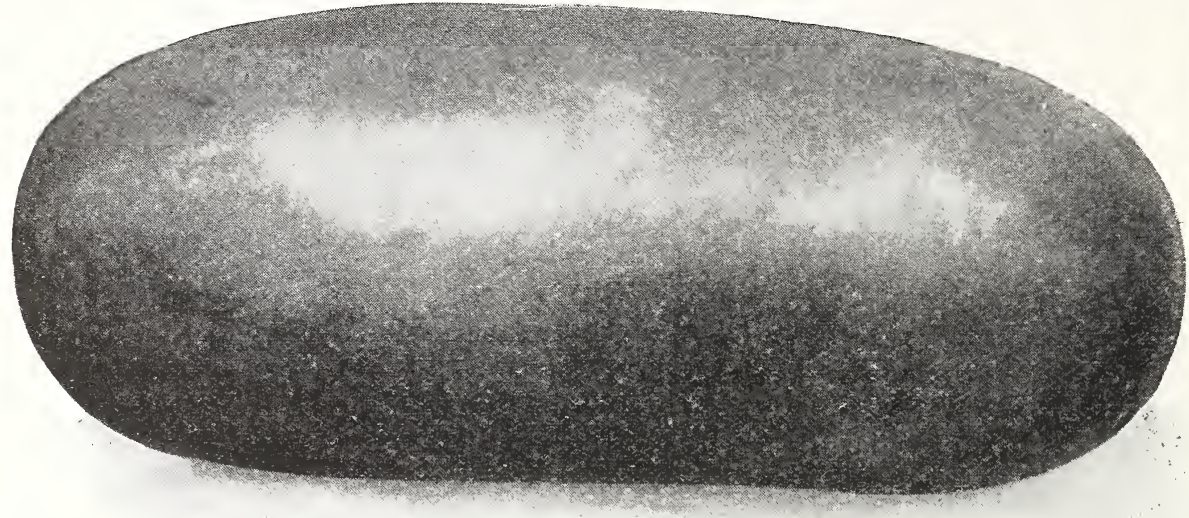

Excel Watermelon

\section{EXCEL}

An excellent shipping melon. A cross between the Watson and Blue Gem. Its size ranges from eighteen to twenty-four inches and weighs from forty to sixty pounds. The deep red flesh is crisp, melting and of the finest flavor. The characteristic of the melon is that the seeds are of a mixed color-some black, some white with black border. The rind is thin, but hard and tough, making it especially adapted for shipping to distant markets. Pkt., 5c; oz., 10c; 1/4 lb., 30c; 1b., $\$ 1.00$.

\section{ALL HEART}

A distinct variety and well worthy of cultivation. Flesh is bright scarlet, sweet and luscious; a strong, vigorous grower; solid as a cannon-ball and averages 30 to 40 pounds; the seed about size of an apple seed. Pkt., 10c; oz., 15c; 1/4 1b., 50c; 1b., \$1.75.

\section{MOUNTAIN SWEET}

This was the great melon of olden times, and was almost the only variety grown extensively for market, but now it is almost entirely discarded for the more modern varieties. We, however, still regard it as first class, producing melons of large size, the flesh of which is bright crimson, sweet and juicy. Pkt., 5c; oz., 10c; 1/4 lb., 30c; 1b., \$1.00.

\section{DUKE JONES}

Similar to Jones or Jumbo. Dark green rind, slightly striped; flesh bright red, exceedingly sweet, juicy and melting; oblong in shape and a good shipper, frequently attaining weight of 70 pounds. Pkt., 5c; oz., 10c; $1 / 4$ lb., 30c; lb., \$1.00.

\section{PREMIUM TRIUMPH}

Grown very largely in some sections of the South for shipping; it attains a very large size, of a flattened, oval form; skin of a deep bluish-green; flesh bright crimson and of excellent quality; it has a tough skin and is a good shipper. Pkt., 5c; oz., 10c; 1/4 lb., 30c; lb., $\$ 1.00$.

\section{IMPROVED KLECKLEY'S SWEET}

Also called Wondermelon. This new strain has the same delicious sweetness and retains all the other fine qualities that made Kleckley's Sweet the favorite home grown melon. The improvement consists of size and shipping qualities. The rind is thin but tough and qualifies for safe shipment for reasonable distances. Pkt., 5c; 1/2 oz., 10c; oz., 15c; 1/4 lb., $40 \mathrm{c}$; lb., \$1.25.

\section{JORDAN'S GRAY MONARCH OR LONG WHITE ICING}

This variety was introduced by us. The skin is of a very beautiful mottled-gray color, long and symmetrically formed, with an exceedingly thin rind; flesh bright crimson and of the sweetest and most delicious flavor. Pkt., 5c; oz., 15c; 1/4 lb., 40c; lb., \$1.25.

\section{CUBAN QUEEN}

This is one of the largest and most productive varieties grown. Rind thin and solid, with dark and light green stripes. Pkt., 5c; oz., 10c; 1/4 lb., 30c; lb., \$1.00.

\section{THURMOND GRAY}

An excellent shipping variety. Melons are long, grayish-green in color, flesh bright red, free from strings; is fine grained, crisp and tender and does not sunburn. A good melon for the home garden. Pkt., 5c; 1/2 oz., 10c; oz., $15 c$; $1 / 4$ lb., $40 c$; lb., $\$ 1.25$.

\section{JACKSON}

One of the sweetest melons for home use. Rind thin, flesh rich scarlet, sweet and delicious. Pkt., 5c; 1/2 oz., 10c; oz., 15c; $1 \frac{1}{4}$ lb., 40c; lb., \$1.25.

\section{COLORADO PRESERVING}

Used exclusively for preserving. Flesh clear white and very solid; seed olive green color. Pkt., 5c; oz., 10c; $1 / 4$ lb., 30c; lb., 


\section{MUSTARD}

The leaves are used as a salad or cooked like spinach and turnip tops, and make a healthy type of "greens." Sow in drills 1 foot apart. For a succession sow every two weeks. Cut when young. One ounce will sow 100 feet; 3 pounds per acre.

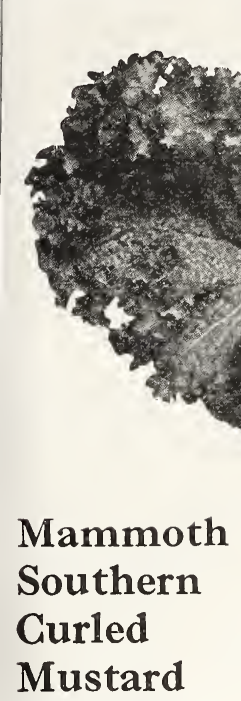

(Buist's Strain)

Mammoth Southern CurledA variety producing beautifully curled leaves, which are larger in their growth than any other variety; very popular in the Southern States, and the best variety to sow. Pkt., 5c.; oz., 10c.; $1 / 4$ lb., 25c.; lb., $75 \mathrm{c}$.

Chinese Broad Leaf-A very hardy, broad-leaved variety; leaves thick and deeply savoyed, broad white midrib. Pkt., 5c.; oz., 10c.; I/4 lb., 25c.; lb., 75c.

Florida Broad Leaf-This variety is distinct and does 1.ot shoot to seed as quickly as other sorts. The leaves are large, broad, comparatively smooth and have broad, distinct midrib. When cooked the leaves are of excellent quality. Pkt., 5c.; oz., 10c.; I/4 lb., 30c.; lb., 90c.

White or Yellow London-Used both as a salad and for flavoring purposes Oz., 10c.; $1 / 4$ lb., 20c.; lb., 60c.

\section{MUSHROOM SPAWN}

The principal cause of failure to grow Mushrooms is from using old spawn. The finest spawn is Lambert's Pure Culture Spawn, prepared for us in brick form.

Mushrooms can be grown much easier than is generally supposed. They can be raised in a cellar, shed, cave or quarry, or even in beds prepared in the open air in the same manner as hotbeds. Procure fresh horse manure (free from litter or straw), and old pasture soil; mix thoroughly in proportion of three parts horse manure to one of loam; turn daily until the extreme heat is out of it. Then select the location for growing them; make out of this compost a bed 4 feet wide, 8 inches deep, and as long as desired, pressed solidly. Leave this unti! the heat subsides to 90 de-

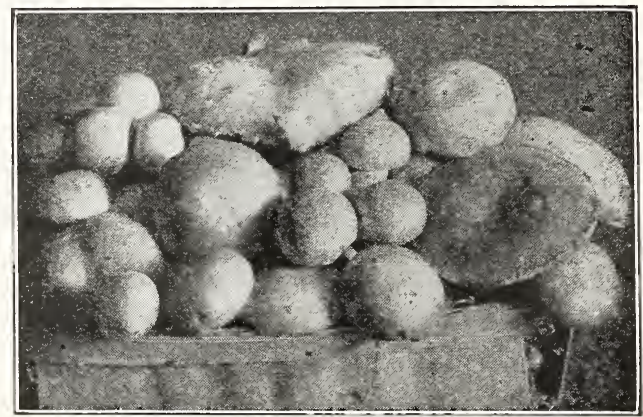
grees, then plant pieces of spawn the size of a walnut in ho'es 2 or 3 inches deep, six apart each way; cover over with the compost, and in the course of a week or ten days the spawn will be diffused through the whole bed. Now cover with 2 inches of fresh soil, and over this spread 3 to 4 inches of hay, straw or litter. If surface becomes dry, wet with lukewarm water. Keep an even temperature of 50 to 60 degrees. It requires, on an average, six to eight weeks to produce mushrooms after the spawn is planted.

Pure Culture Spawn-Brick, 35c.; 5 bricks, $\$ 1.50 ; 10$ bricks, $\$ 2.75 ; 25$ bricks, $\$ 6.50$; 50 bricks, $\$ 12.50$. By mail-postage, 10 c. per brick extra.

"Buist's Mushroom Culture" free on application, telling how to prepare the mushroom bed and take care of the crop. If interested in growing mushrooms write for a copy. 


\section{OKRA, OR GUMBO}

$\mathrm{T}$

HIS is a highly esteemed vegetable throughout the entire country. The seed-pods are used in soups, while young and tender, to which it imparts an aromatic flavor; they are also stewed and served with butter. Sow the seed late in Spring, in very rich soil, in drills 2 feet apart, observing that the ground is warm, for if cold and moist, the seeds will invariably rot; when the plants are up, thin out to a foot apart. When canned it is also one of the most delightful vegetables for Winter use, especially when canned with tomatoes.

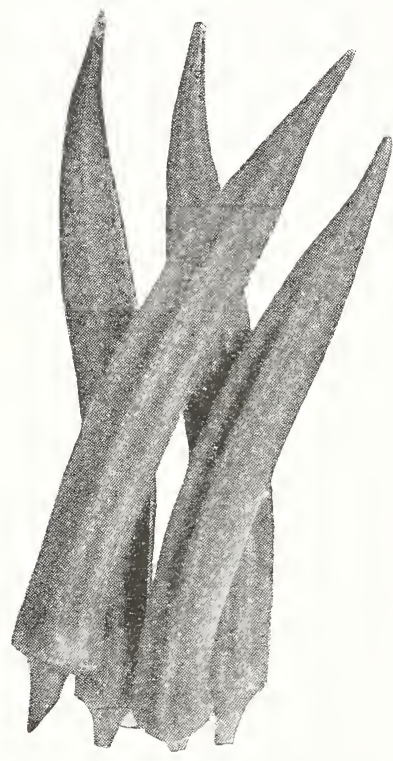

Perkins' Mammoth Podded Okra

\section{THE BUIST'S DWARF}

The Dwarf Okra was introduced by us some years ago and it has become the most popular dwarf variety with all growers. Its characteristics are not only its dwarf habit, but its earliness and great productiveness. The pods are twice the size of the common variety and grow from an inch above the ground to the top. Plkt., 5c; oz., 10c; 1/4 lb., 25c; lb., $75 \mathrm{c}$.

\section{PERKINS' MAMMOTH GREEN PODDED}

This extraordinary variety is not only the most productive known, but forms enormous-sized pods, and is earlier than any other variety. It is a large cropper, and is not only very highly prized by growers, but owing to its great tenderness, is preferred by canners, who preserve it hermetically for Winter use. Its average growth is 4 feet, and each plant produces on an average from twenty to thirty pods, which are of a beautiful green color. Pkt., 5c; oz., 10c; 1/4 lb., 25c; lb., 75c.

\section{TALL OR LONG GREEN}

A tall-growing variety, producing long, thin pods. Pkt., 5c; oz., 10c; 1/4 lb., 25c; lb., 75c.

\section{WHITE VELVET OR CREOLE}

An entirely distinct variety, the pods are round and smooth, but covered with a fine fibre resembling velvet. Extremely tender and prolific. Pkt., 5c; oz., 10c; 1/4 lb., $25 \mathrm{c} ; \mathrm{lb} ., 75 \mathrm{c}$.

\section{BUIST'S PEDIGREE ONION SEED HOW TO GROW ONIONS}

Culture-The Onion is a heavy feeding plant with numerous spreading roots that absorb nourishment from every part of the soil; therefore the liberal use of manure or other suitable fertilizer is necessary for every crop. Onions, unlike most vegetables, may be cultivated on the same land for a succession of years if the ground is kept well enriched.

They respond best to well-rotted stable manure which should be heavily applied in the autumn, and plowed in early the following spring. If manure, which becomes more difficult to obtain each year, is not available, a high-grade commercial fertilizer, at the rate of one ton per acre, may be applied to good advantage. This should be thoroughly worked with the top soil, after plowing in the early spring, and the plowed soil should be thoroughly pulverized and levelled with a rake or harrow.

Seed should be sown as early as the ground can be prepared in rows 15 inches apart and $1 / 2$ inch deep. Cover well with fine soil and press down with a light roller or the back of a spade. Keep the rows clear of all weeds by frequent hoeing. Do not hoe deeply, for the more the Onion rises out of the ground, the finer it is and the better it keeps. When the young plants are 3 inches high, thin them out to stand 3 inches apart.

For growing large Onions one ounce is sufficient for 100 feet of drill, or 5 to 6 pounds per acre.

How to Grow Onion Sets-Seed should be sown very thickly in shallow drills early in the spring. Sixty pounds of seed per acre is required and the best varieties are White Silver Skin, Yellow Globe Danvers, Japanese and Large Red Wethersfield.

The young plants form small Onions about the size of marbles by mid-summer when the foliage becomes brown and dry, and the crop may then be harvested. Sets require cool storage. Freezing will not hurt them if they are not handled while in that condition. 


\section{Buist's Pedigree Onion Seed}

\section{SOUTHPORT YELLOW GLOBE}

The Onion which is best $\mathrm{known}$ throughout $t$ he United States is the Southport strain. They are preferred by many to any other variety, not only for the enor. mous crops they produce, but for their fine keeping qualities. They produce large and uniform bulbs with very small necks. The Southport Yellow Globe is perfectly globe-shaped and beautiful in color and form. The flesh is creamy white, fine grained, and of mild and ex. cellent flavor. Pkt., 10c; 1/2 oz., 15c; oz., 25c; 1/4 lb., $65 \mathrm{c} ; 1 \mathrm{~b} ., \$ 2.25$.

\section{BUIST'S YELLOW GLOBE DANVERS}

This is the most popular and the most extensively grown main crop Yellow Onion, both for the market and home garden. Of more globular shape than the Southport,

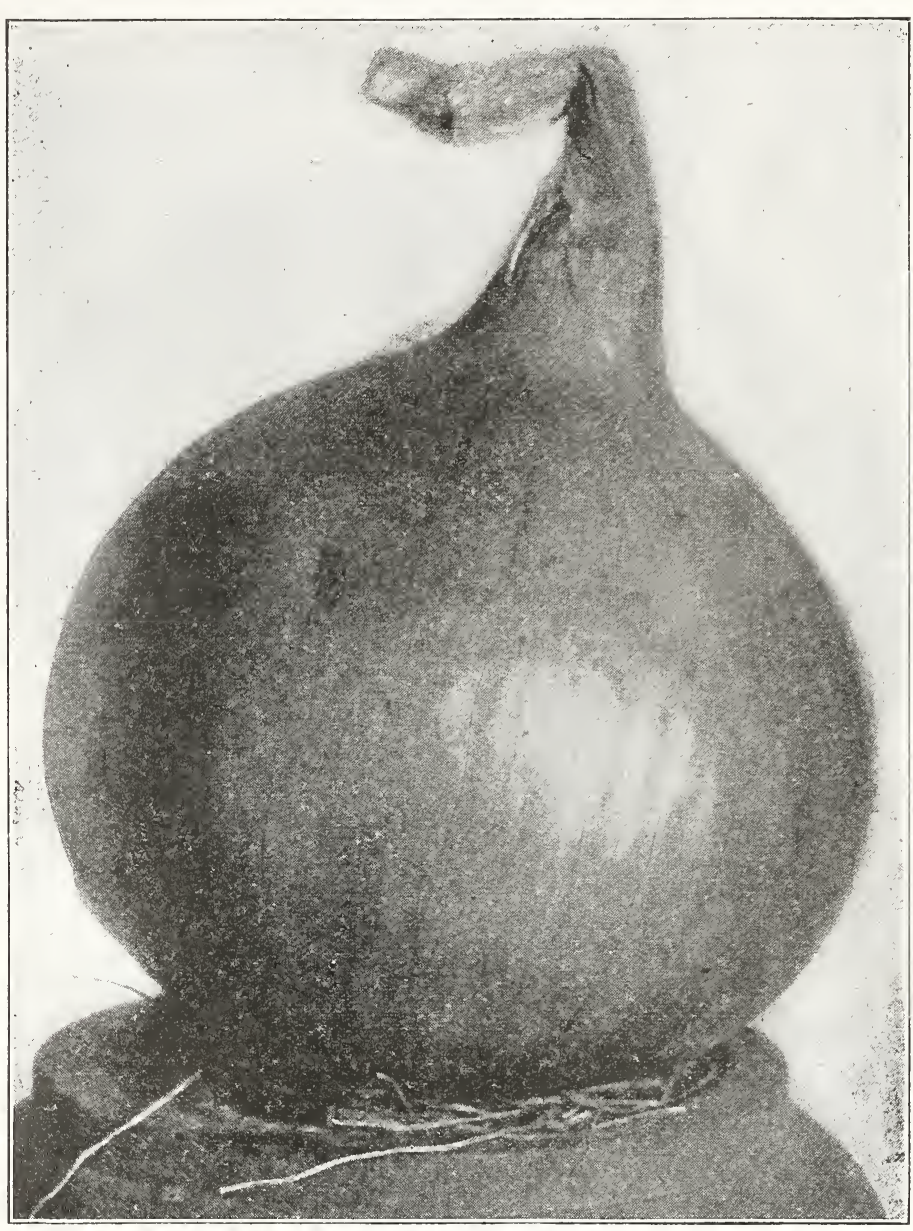

Southport Yellow Globe Onion

with very small neck, beautiful yellow skin and pure white flesh of fine quality. The crop ripens uniformly at one time and is a splendid keeper. Our strain is unsurpassed and being a few weeks earlier than the South. port Globe, it sells for the higher early market price. Pkt., 10c; oz., 20c; 1/4 lb., 65c; lb., $\$ 2.25$.

\section{WHITE PORTUGAL OR SILVERSKIN}

This is the famous variety which is sown so extensively for growing Onion Sets. It is not only the mildest but the most delicate flavored variety, and generally preferred for table use; of a silver-white color, and exceed. ingly attractive; it is also used when quite small for pickling purposes. Matures ten days earlier than the White Globe. Pkt., 10c; $1 / 2$ oz., 15c; oz., 25c; 1/4 lb., 80c; lb., \$2.75.

\section{SOUTHPORT RED GLOBE}

With the exception of color, this variety is identical with the Southport Yellow Globe; its beautiful form and rich, purplish crimson color makes it a very salable variety, and in some localities it is preferred to the Yellow. The flesh is white, tinged with light purple, mild and tender. Pkt., 10c; 1/2 oz., 15c; oz., 25c.; 14 lb., 75c; lb., $\$ 2.50$.

\section{SOUTHPORT WHITE GLOBE}

Produces handsome and uniformly globeshaped bulbs, and always command the highest market price. The flesh is firm, finegrained and mild in flavor. Our strain is unsurpassed in uniformity and beauty of shape and color. Pkt., 10c; 1/2 oz., 15c; oz., 30c; $1 / 4$ lb., 90c; lb., \$3.00. 


\section{Buist's Pedigree Onion Seed}

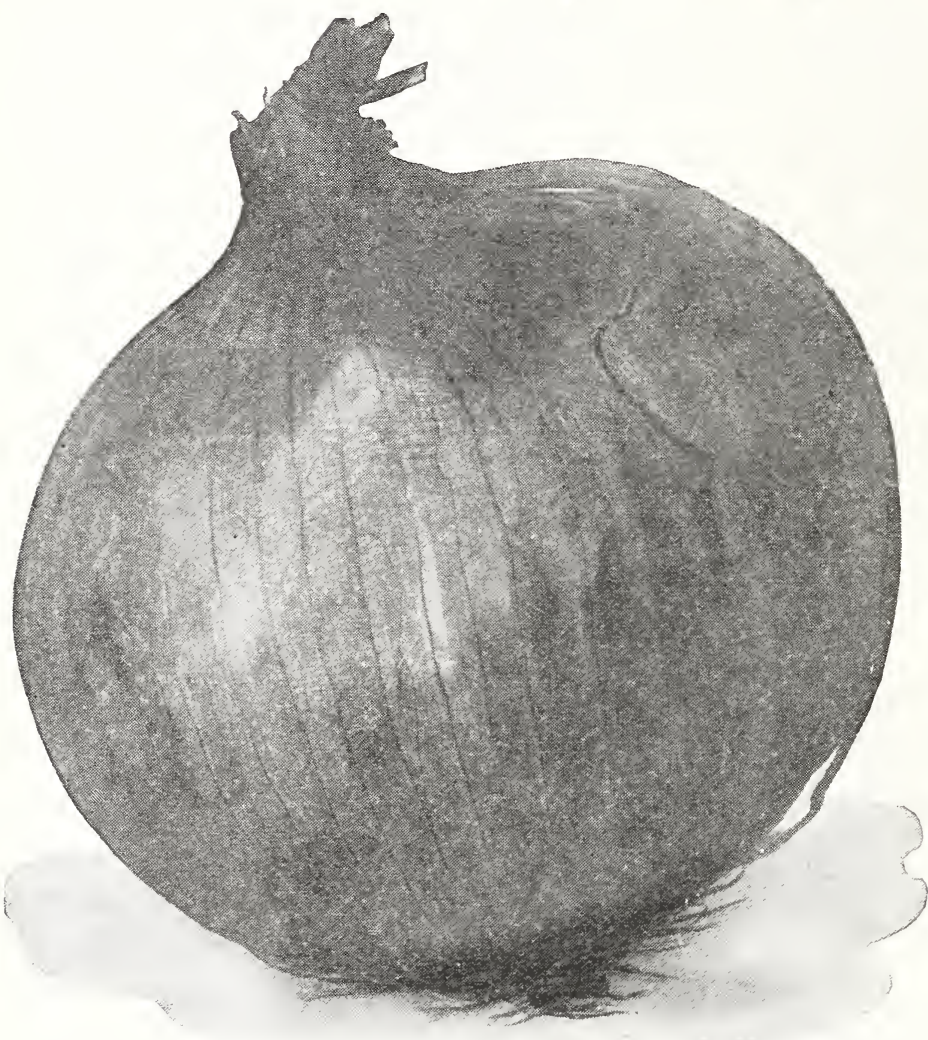

\section{Buist's \\ Prizetaker \\ Onion}

"The King of All"

The Great Yellow Prize-Taker Onion This variety has become famous all over the world, not only for its enormous size, but for the beautiful formed and attractive Onions it produces, w h i c h frequently $\mathrm{measure} 12$ to 15 inches in circumference and from 3 to 5 pounds in weight; producing large Onions same season. They are of a rich straw color and ex. tremely mild and delicate in flavor; a single Onion will make a dish for a small family; they are crisp and solid and a good keeping variety. Excels in size, yield and $\mathrm{gre}$ a t solidity; highly recommended. Pkt., 10c; oz., 20c; 1/4 lb., 65c; lb., \$2.25.

The Great Yellow Prize-Taker Onion

\section{YELLOW DUTCH OR STRASBURG}

A valuable general crop sort. The bulbs are of medium size and flat. The skin is straw color, flesh creamy white, mild, and of pleasant flavor. This is the most popular variety for producing yellow sets and cannot be excelled for that purpose. Pkt., 10c; oz., 20c; 1/4 lb., 60c; lb., $\$ 2.00$.

\section{LARGE RED WETHERSFIELD}

This is another standard variety in the Eastern and Western States, where immense crops are grown for shipment; is of a purplish. red color, of a round or oval shape, and is an excellent keeping variety. Pkt., 10c; oz., 20c; $1 / 4 \mathrm{lb}$., 60c; lb., \$2.00.

\section{AUSTRALIAN BROWN}

This variety, owing to its extraordinary keeping qualities, has gained great popularity; it is of roundish form, of a beautiful amber. brown color, of mild flavor. Pkt., 10c; oz., 20 c; $1 / 4$ lb., 60c; lb., \$2.00.

\section{EBENEZER OR JAPANESE}

This variety is used extensively for growing Onion Sets, color a deep yellow and of very mild flavor. Japanese Sets produce more marketable Onions than either the Strasburg or Danvers. They are wonderful keepers and rarely produce seed stalks as others do, only a very small per cent of the sets run to seed. Pkt., 10c; 1/2 oz., 15c; oz., 25c; 1/4 lb., 75c; lb., $\$ 2.50$.

\section{OHIO YELLOW GLOBE}

A very desirable strain of yellow globeshaped Onions, and very popular among the large Onion growers of Ohio. The main features which distinguish this strain from others are its attractive even color, small necks and earliness. The Onions are firm, solid and keep exceptionally well during the winter. Pkt., 10c; oz., 20c; 1/4 lb., 65c; lb., \$2.25.

MARKET GARDENERS and ONION GROWERS who use large quantities of Onion Seed will please write for WHOLESALE PRICES 


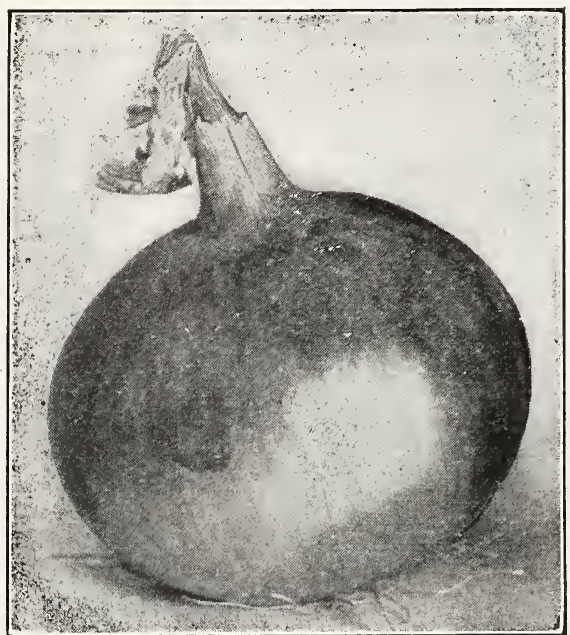

Riverside Sweet Spanish Onion

\section{RIVERSIDE SWEET SPANISH}

A popular Onion in Southern California and the West. The bulbs are extremely large, almost globular in shape and very short necks. The skin is golden yellow, flesh white of very fine texture and extremely mild flavor. An ideal Onion for the South, as it requires a warm long season for best development. Pkt., 10c; 1/2 oz., 15c; oz., 30c; 1/4 lb., \$1.00; lb., \$3.50.

\section{GIANT GIBRALTER}

A variety similar to the Prize-Taker but larger in size. The Onions are globeshaped, deep yellow, very smooth and handsome. Flavor very mild and pleasant. Pkt., 10c; $1 / 2$ oz., 15c; oz., 30c; 1/4 lb., 90c; lb., \$3.00.

\section{WHITE BUNCHING}

A rapid growing variety of mild flavor, maturing small, snowy-white Onions of very fine quality long before other sorts are ready. For early bunching or using green, it is un, surpassed. Pkt., 10c; 1/2 oz., 15c; oz., 30c; $1 / 4$ lb., 90c; lb., $\$ 3.00$.

\section{ITALIAN VARIETIES OF ONION}

\section{MAMMOTH WHITE SILVER KING}

This is undoubtedly the largest, mildest and most attractive of all the Italian varieties, and unequalled for the table; if there is such a thing as a delicate flavored Onion, you have it in this variety. It is an annual variety, quite early, and attains perfection the first year from seed; of a beautiful silvery white color; independent of its fine qualities, it is really a wonder in appearance and very attractive. Pkt., 10c; 1/2 oz., 15c; oz., 25c; 1/4 lb., 75c; lb., $\$ 2.50$.

\section{EARLY WHITE BARLETTA}

This variety is two weeks earlier than the famous White Queen; it is regarded as the earliest variety in cultivation. When crop is matured the tops die down close to the bulb, leaving the most perfect miniature Onions imaginable, ranging from 1 to $11 / 2$ inches in diameter; of a pure paper-white color, exceedingly mild and delicious in flavor; it is a grand variety for pickling purposes and if sown thickly in rows will produce small round onions of the size of marbles. Pkt., 10c; 1/2 oz., 30c; 1/4 1b., 90c; 1b., \$3.00.

\section{GIANT WHITE ITALIAN TRIPOLI}

A very superior variety, of flat form and large size, with a beautiful silvery-white skin and of mild flavor. Pkt., 10c; 1/2 oz., 15c; oz., 25c; 1/4 lb., 80c; lb., \$2.75.

\section{GIANT YELLOW ROCCA}

This variety is of a globular form, with a light-yellowish-brown skin; is exceedingly mild and of a very delicate flavor; it requires the full season to form large Onions. Pkt., 10c; oz., 20c; 1/4 lb., 65c; lb., $\$ 2.25$.

\section{EXTRA EARLY WHITE PEARL}

A very early white variety, almost as trans. parent as a pearl, of flat form, and of very mild and pleasant flavor, and attains quite a large size, and one of the very best varieties for the South. Pkt., 10c; 1/2 oz., 15c; oz., 25c; 1/4 lb., 80c; lb., \$2.75.

\section{EARLY WHITE QUEEN}

A fine, early silver-skinned variety, of beautiful form and rapid growth, and pos. sessing fine keeping qualities. Pkt., 10c; 1/2 oz., 15c; oz., 25; 1/4 lb., 80c; 1b., \$2.75.

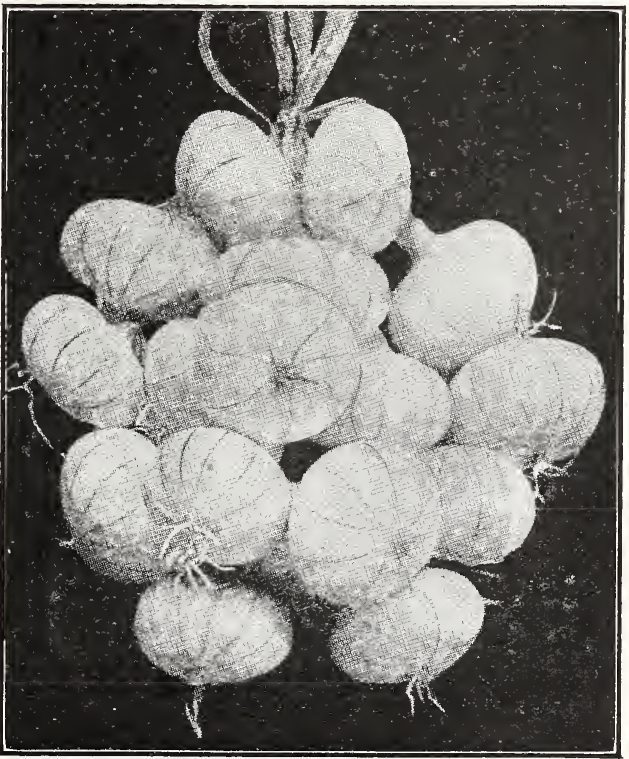

White Barletta Onion 


\section{BERMUDA ONION SEED}

GENUINE TENERIFFE GROWN

We make a specialty of growing the Crystal White Wax, Red and White Bermuda Onion Seed at Teneriffe, in the Canary Islands, where the best Bermuda Onion Seed in the world is produced. These varieties of Onions are very extensively raised in Texas and the other Southern States, where thousands of carloads are annually grown for shipment to Northern and European markets. The importance of securing reliable seed cannot be overestimated; the seed we offer is of the very finest strain.

Crystal White Wax-This new variety is very popular with the Onion growers of Texas. An absolutely pure White Onion of a beautiful waxy appearance. It is very fine for slicing, the color being so clear and pure. The sweetest and mildest of all the Bermuda Onions; there is a great demand for it on the market, on account of its handsome appearance. Our strain has no superior. Pkt., 10c.; 1/2 oz., 20c.; oz., 35c.; I/4 lb., $\$ 1.15 ;$ lb., $\$ 4.00$.

White or Yellow - The name of this variety is misleading, for while it is known as a White Bermuda, it is really of a straw color, or pale yellow. It is exceedingly mild in flavor and very early, identical in shape and size with

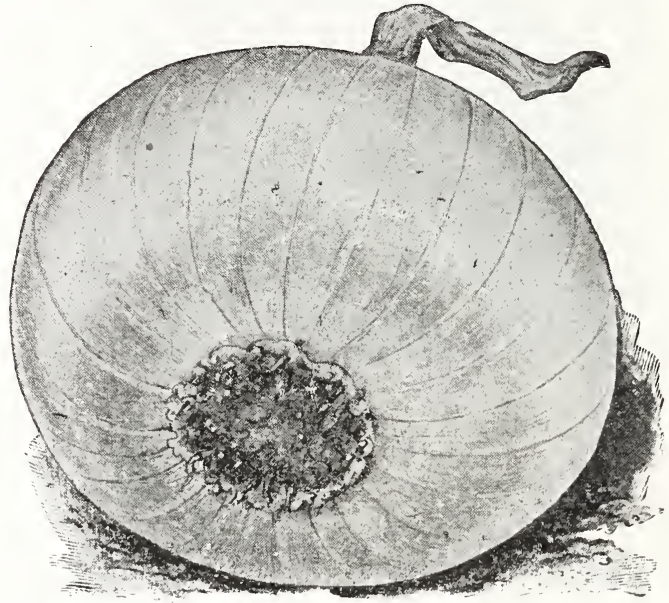

Crystal White Wax

Red Bermuda-This is the most popular variety for home use and market; color a pale, waxy red, flesh white suffused with pink, quite early and very solid. Pkt., 10c.; $1 / 2$ oz., 20c.; oz., 35c.; $1 / 4$ lb., $\$ 1.15 ; 1 \mathrm{~b}$., $\$ 4.00$. extremely thin-necked, insuring even and early ripening. A very profitable sort for market gardeners and truckers. Pkt., 10c.; $1 / 2$ oz., 25c.; oz., 45c.; $1 / 4$ lb., $\$ 1.50 ; 1$ lb., $\$ 5.00$.

\section{BUIST'S SELECTED ONION SETS}

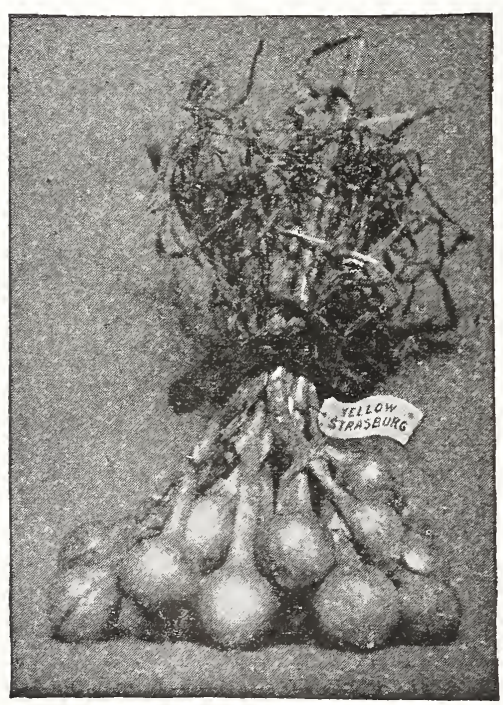

Onion Sets
Plant in the spring as soon as the ground can be worked, and the green onions will be ready for use in a few weeks. In planting Onion sets draw out drills about an inch deep and nine inches apart, leaving a space 15 inches between every three or four drills for convenience in hoeing. Firm the small sets in these drills about 3 inches apart, but do not cover them. Keep the ground clear of all weeds by frequently hoeing until the crop will be ready for lifting in July. One quart will plant 50 feet of drill, 10 bushels per acre.

For early green Onions plant the Egyptian Top Sets or Winter Onion. They are planted only in the fall and grown as a green onion as they do not form a bulb. We can supply them from August 15th to October 15th.

$\begin{array}{lrrr} & \text { Per Qt. } & 4 \text { Qts. } & \text { Peck } \\ \text { White Onion Sets....... } \$ 0.25 & \$ 0.85 & \$ 1.50 \\ \text { Dark Red Onion Sets.... } & .20 & .70 & 1.20 \\ \text { Yellow Onion Sets..... } & .20 & .70 & 1.20 \\ \text { Japanese Onion Sets.... } & .25 & .85 & 1.50 \\ \text { Egyptian Winter Sets... } & .20 & .60 & 1.00\end{array}$

If wanted by mail, add postage to cover Parcel Post. One quart weighs about one pound. Write for special quotations on large quantities. 


\section{PARSLEY}

Parsley is valuable for flavoring and garnishing purposes. Sow in drills as early in Spring as the soil can be pulverized. Seed two years old will vegetate more freely than new seed, which will frequently require five or six weeks to germinate; so the cultivator must not be disheartened if the plants do not appear within a month. The seed will also germinate more freely by soaking it twenty-four hours in water, and mixed with sand before sowing.

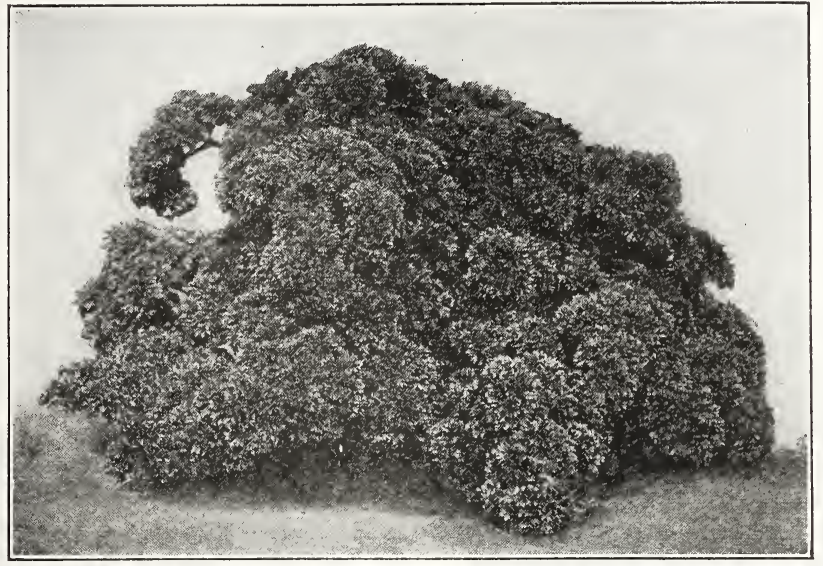

Buist's Garnishing Parsley

Buist's Garnishing, or Dwarf Perfection-This variety is a general favorite, and is especially recommended for market gardeners, as it stands the Winter well, is of strong growth, beautifully curled, of an attractive emerald green color. It is the most salable of all varieties. Pkt., 5c.; Oz., 15c.; 1/4 lb., 40c.; lb., $\$ 1.25$.

Dark Moss Curled-A famous English variety, and very popular in this country. It is beautifully curled, dark green leaves, excellent for garnishing. Pkt., 5c.; oz., 15c.; $1 / 4$ lb., 40c.; lb., \$1.25.

Plain or Single-This is the hardiest variety; foliage very dark green;

Double Curled, or Covent Garden-A desirable market variety of very dark green color and quite dwarf in habit; is not, however, as curly as the Garnishing varieties, but stands the Winter better and retains its color the entire season; is very popular with market gardeners. Pkt., 5c.; oz., 15c.; 1/4 lb., 35c.; lb., $\$ 1.10$.

\section{PARSNIP}

Culture-Sow in Spring as soon as the weather will permit, in rows 18 inches apart. Cover seed $1 / 2$ inch deep; thin out to 5 inches apart in rows when plants are large enough. A little frost improves the flavor. Take up what is wanted for Winter use, leaving the rest in the ground for Spring use.

Sugar, or Hollow Crown-This is the variety most generally grown for either table use or stock feeding; it is of uniform

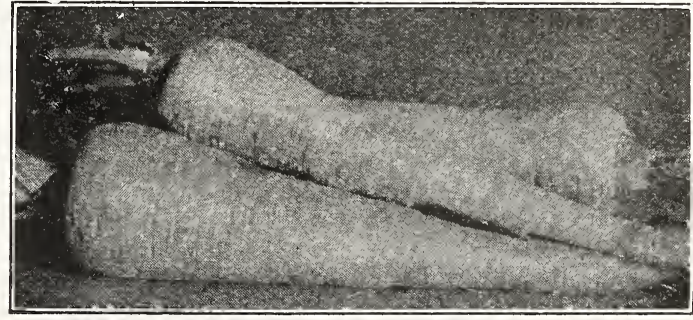

Sugar or Hollow Crown Parsnip

Student, or Guernsey-This variety is much in favor. It is delicate in flavor, of regular form, has a very smooth skin. Pkt., 5c.; oz., 10c.; 1/4 lb., 30c.; lb., $\$ 1.00$. 


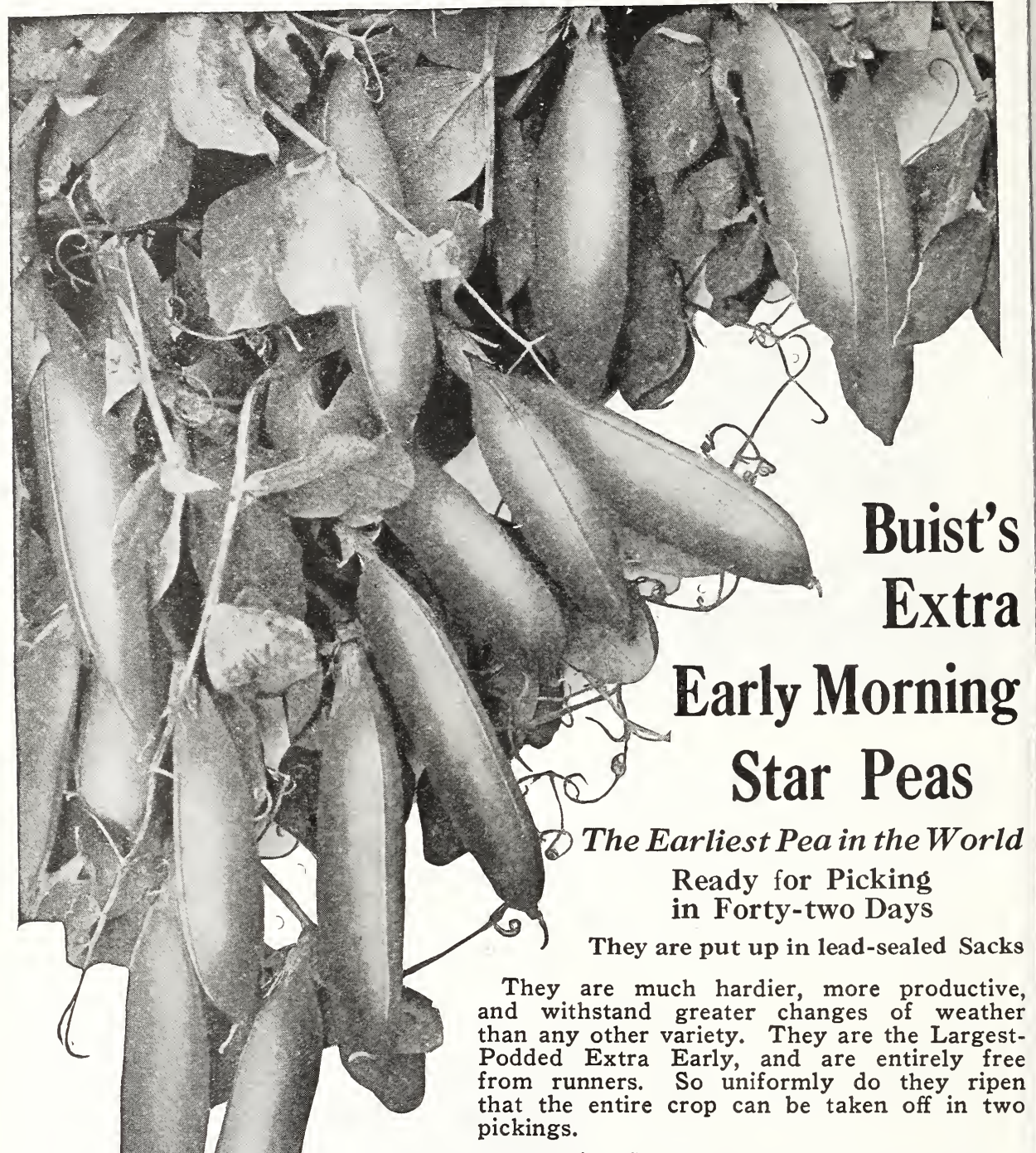

Buist's Early Morning Star Peas have always maintained a very high reputation with gardeners for earliness, productiveness and fine qualities, and are to-day the best known and the most popular among all growers. We have been selecting and reselecting the seed stock for a number of years and they now excel in purity and are without doubt the earliest pea on the market.

Where EARLINESS, productiveness, large-sized pods and sweetness of flavor are desired, this is the variety to grow. It may be truly called the BLOODED STOCK OF EXTRA EARLIES, and stands at the head of the list for the above fine qualities. In a favorable season they will be ready for market in forty-two days, and the entire crop can be taken off in one or two pickings.

Sow them; you will make no mistake. We annually grow 500 acres of them. Their growth ranges from two to two and a half feet, in accordance with the season; they are entirely free from runners and never require sticking; it is an easy variety to pick, as almost a handful can be grasped at a time. Pkt., 10c.; lb., 30c.; 2 lbs., 55c.; $7 \mathrm{I} / 2 \mathrm{lbs}$., $\$ 1.80 ; 15 \mathrm{lbs}$., $\$ 3.40$. 


\section{GARDEN PEAS}

First Early and Early Varieties

Market Surprise-A new smooth seeded extra early, growing about 30 inches high, very hardy, having large pods which contain eight or nine peas of excellent quality ready for picking in 50 days. For productiveness, earliness, evenness of ripening and delicacy of flavor it has no equal and these combined requisites make it very profitable to grow for either market or private use. Pkt., 10c.; lb., 25c.; 2 lbs., 50c.; 10 lbs., $\$ 2.00$.

Early Alaska-This is the earliest blue variety in cultivation; the dark green color of its pod makes it a desirable shipping variety, as it will carry long distances without losing color; this quality, combined with its extreme earliness, recommends it very highly to the market gardener; height $21 / 2$ feet; is also the most popular variety for canning, being almost exclusively used for that purpose by the largest canning establishments. Pkt., 10c.; 1b., 25c.; 2 lbs., 50c.; 10 lbs., $\$ 2.00$.

Ameer (Claudit) - A new extra early Pea of excellent quality, follows the Gradus which it excels as a cropper. The peas ripen uniformly, the pods are long and of a dark green color, sweet, tender and of a delicious flavor. Height 3 feet. We recommend it to all large Pea growers and shippers. Pkt., 10c.; 1b., 25c.; 2 lbs., 50c.; 10 lbs., $\$ 2.00$.

Early Bird-A very hardy large podded early pea, bearing deep green pods 4 inches long well filled with 8 or 9 very large, dark green peas. Height 20 inches. Pkt., 10c.; 1 lb., 30c.; 2 lbs., 55c.; 10 lbs., $\$ 2.20$.

Large-Podded Alaska-Peas and pods almost double the size of the Early Alaska, the vine is more vigorous, 3 feet in height and a heavy producer of broad, dark green pods of fine flavor. Pkt., 10c.; lb., 25c.; 2 lbs., 50c.; 10 lbs., $\$ 2.00$.

Nott's Excelsior-This is a very early wrinkled variety of great merit. It combines the good qualities of American Wonder and Premium Gem. Vines about 15 inches high, pods about 3 inches long. The peas in sweetness and quality are unsurpassed. Pkt., 10c.; lb., 30c.; 2 lbs., 55c.; 10 lbs., \$2.25.

Sutton's Excelsior-Similar in habit and growth to the famous Nott's Excelsior, but producing very large, broad pods, $31 / 2$ inches long, well filled with fine, large, wrinkled peas, which are of the very finest quality and flavor. Pkt., 10c.; lb., 30c.; 2 lbs., 55c.; 10 lbs., \$2.25.

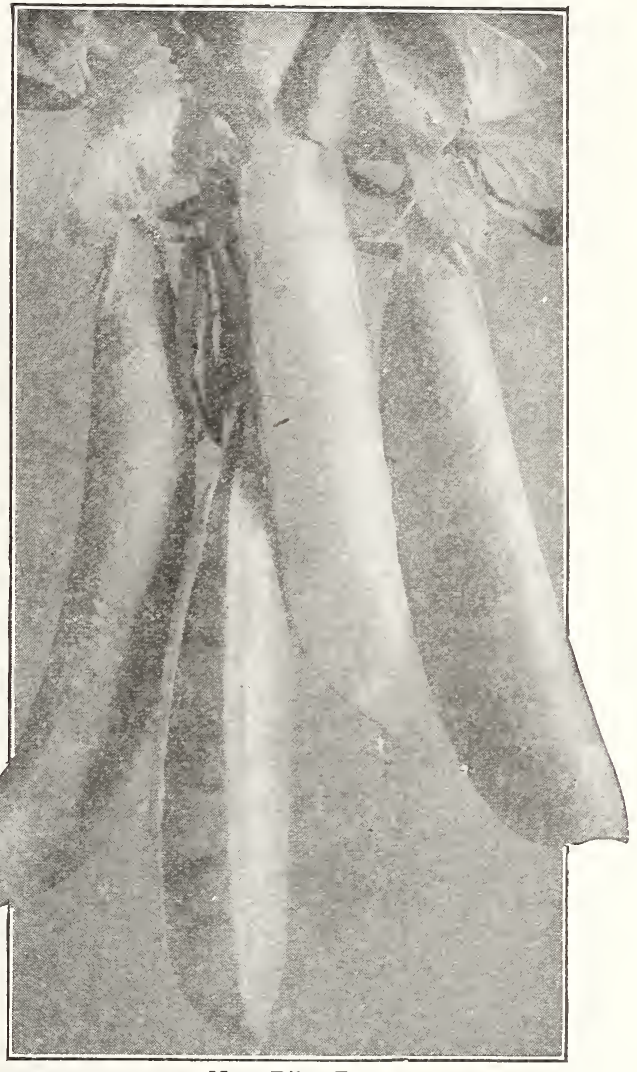

New Pilot Pea

The New Pilot-This is one of the new, extra early, long podded sorts of the Thomas Laxton type. A vigorous grower, standing severe changes of weather, and can be planted as early as the Alaska and other extra early varieties. Vines about $2 \mathrm{I} / 2$ feet, loaded with fine, large, well-filled pods. A very profitable Pea for growers and shippers. Pkt., 10c.; lb., 35c.; 2 lbs., 65c.; 10 lbs., $\$ 2.50$.

Blue Bantam-A very fine dwarf early Pea, combining extreme earliness, superb quality, and unusual productiveness. The dark green pods, 4 inches long, are broad, straight and pointed, containing 8 to 10 very large, deep green peas of superb quality. Pkt., 10c.; lb., 35c.; 2 lbs., 65c.; 10 lbs., $\$ 2.50$.

First and Best-A white-seeded extra early, very prolific, strong, vigorous and hardy. Pods are well filled. Pkt., 10c.; 1b., 25c.; 2 lbs., 50c.; 10 lbs., $\$ 2.00$. 


\section{EXTRA EARLY GRADUS OR PROSPERITY}

This is the most famous of all the wrinkled varieties, and cannot be recommended too highly. New varieties of Peas are annually being introduced, but generally fade from sight in a year or two, but the Gradus is an exception. It has come to stay, and will always be popular and famous for its fine qualities. Early sowings of wrinkled Peas are liable to be destroyed by cold weather. It is not so with the Gradus, as it is very hardy; it is a vigorous grower, $21 / 2$ to 3 feet in height, very prolific and producing pods nearly as large as the famous Telephone, 4 to $41 / 2$ inches long, and filled with eight to ten large peas, which are of delicious flavor. Pkt., 10c; lb., 30c; 2 lbs., 55c; 10 lbs., \$2.20.

\section{THOMAS LAXTON}

Closely resembles the Gradus, but is hardier and slightly earlier. Pods are 4 inches long, of a dark green color and square at the end. The vines are vigorous, of medium height, about 3 feet, similar to those of Gradus but darker in color, hardier and more productive. The green peas are very large and unsurpassed in quality. Pkt., 10c; lb., 30c; 2 lbs., 55c; 10 lbs., \$2.20.

\section{LAXTONIAN-"THE DWARF GRADUS"}

This new English introduction is the larg, est podded of all the early dwarf peas. The dark green pods are similar to the Gradus in shape and nearly as large in size; they mature earlier and require no support of any kind. The vines are vigorous and very productive, growth about 15 inches, pods are well filled with peas of the finest flavor. "The Lax. tonian" cannot be recommended too highly. Pkt., 10c; lb., 35c; 2 lbs., 65c; 10 lbs., \$2.50.

\section{LITTLE MARVEL}

An English variety that has taken first rank among the early, large podded dwarf varieties. The pods, 4 inches long, are dark green, vines vigorous and wonderfully productive, height 14 inches. Pkt., 10c; lb., 30c; 2 lbs., 55c; 10 lbs., \$2.20.

\section{PETER PAN}

One of the finest of the large podded, dwarf peas, on the order of Laxtonian, though somer what earlier, height 15 inches, dark green pods $33 / 4$ inches long; very broad, straight and pointed. A most profitable Pea for either the home or market garden. Pkt., 10c; lb., 35c; 2 lbs., 65c; 10 lbs., \$2.50.

\section{HUNDRED FOLD}

This handsome pea of the Laxtonian type is wonderfully prolific, pods dark green, 4 inches long, broad and pointed, containing eight large dark green peas of delicious qual. ity, height 2 feet. Pkt., 10c; lb., 35c; 2 lbs., $65 \mathrm{c} ; 10 \mathrm{lbs} ., \$ 2.50$.

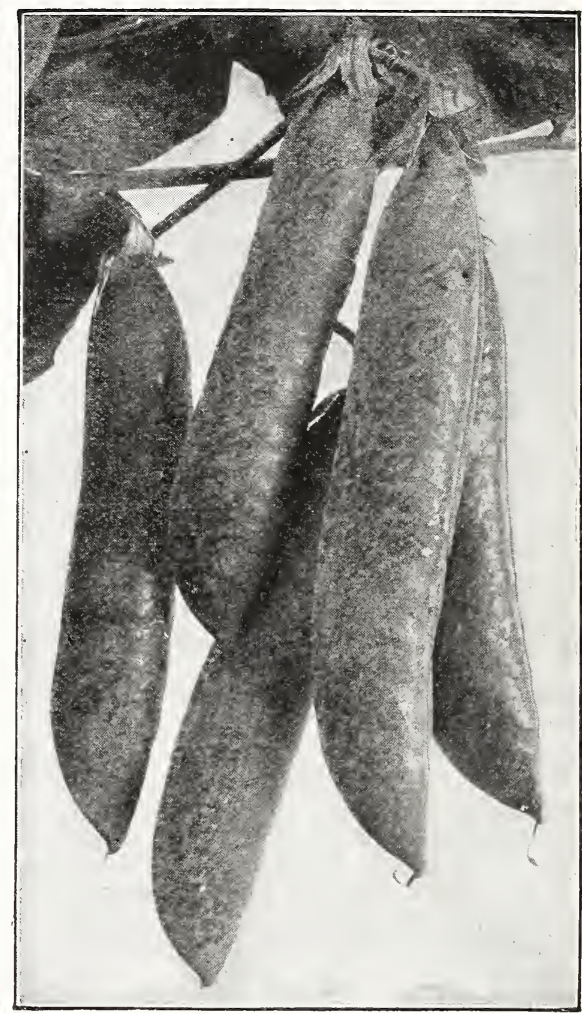

Buist's Early Wonder Peas

\section{BUIST'S EARLY WONDER}

The finest first early wrinkled Pea of recent introduction. The pods are of a handsome deep bluish-green color, four inches long and filled with eight large dark green peas of superb quality. The vines are vigorous in growth, averaging 15 to 18 inches in height and require no support to get the best results Pkt., 10c; lb., 35c; 2 lbs., 65c; 10 lbs., \$2.75.

\section{WORLD'S RECORD}

An early strain of Gradus. Vines are vigorous and very productive. They produce dark green pods 4 to $4 \frac{1}{2}$ inches long, well filled with handsome, very large peas of ex. ceptional fine quality, height $21 / 2$ feet. Pkt., $10 \mathrm{c} ; 1 \mathrm{lb} ., 30 \mathrm{c} ; 2 \mathrm{lbs}$., 55c; $10 \mathrm{lbs}$., $\$ 2.20$.

\section{LAXTON'S PROGRESS}

A very early large podded dwarf wrinkled Pea, an improvement on Laxtonian and four days earlier. Pods are 4 inches long, broad and pointed, deep green in color, containing eight large deep green peas, which are of the most delicious flavor. Pkt., 10c; 1 lb., 35c; 2 lbs., $65 \mathrm{c}$ : $10 \mathrm{lbs}$., $\$ 2.75$. 


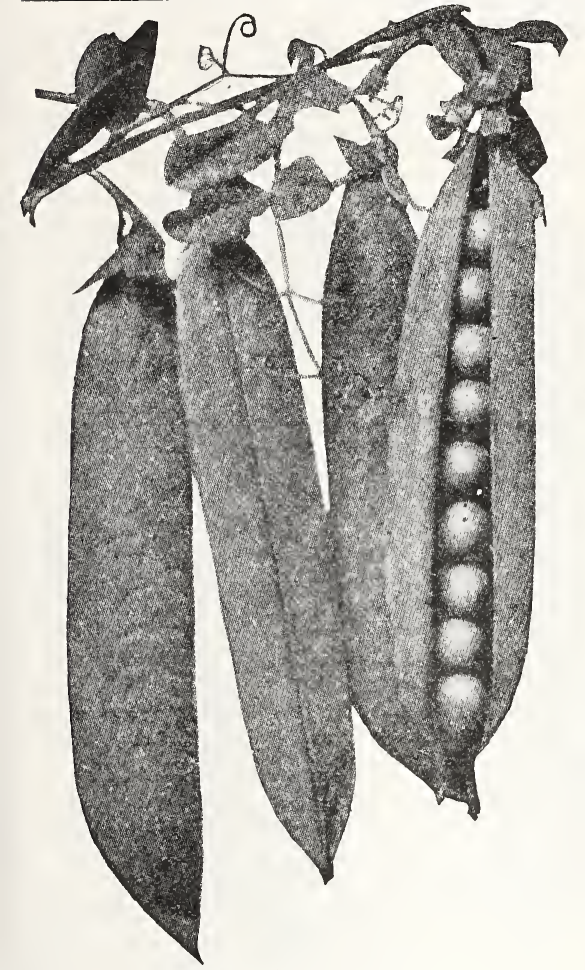

Buist's Early Klondike Peas
BUIST'S NEW EARLY KLONDIKE

The distinctive merit of this new variety is its great hardiness, combined with exceptional quality and productiveness. It is hardier than Gradus and will not rot in the cold ground as wrinkled peas do. Standing severe changes of weather, it can be sown earlier. Is a tremendous cropper, producing long, dark, green pods, filled with peas of finest quality. Height, 30 inches. Pkt., 10c; lb., 35c; 2 lbs., 65c; 10 lbs., \$2.50.

\section{PREMIUM GEM (Improved Little Gem)}

A very desirable early wrinkled dwarf variety, especially recommended to private growers. Very productive; height 18 inches; pods light green, 3 inches long and filled with peas of splendid quality. Pkt., 10c; lb., 30c; 2 lbs., 55c; 10 lbs., \$2.20.

\section{DWARF TELEPHONE OR DAISY}

This Pea is one of the favorites among the market gardeners of the South. Vines are strong and heavy, height 2 feet, pods dark green, $4 \frac{1}{2}$ inches long, containing 8 to 10 peas of finest quality. Pkt., 10c; 1b., 30c; 2 lbs., 55c; 10 lbs., \$2.20.

\section{EARLY AMERICAN WONDER}

A very fine extra early wrinkled variety, especially adapted for private gardens. Pods are firm and well filled with peas of sweet and delicious flavor. Height about 12 inches. Pkt., 10c; lb., 30c; 2 lbs., 55c; 10 lbs., \$2.20.

\section{PEAS, Late or Main Crop}

\section{POTLATCH}

In the Chinook dialect, "Potlatch" means big dinner, and the name is given to this variety on account of its great productiveness. It is of the Stratagem class, has a very dark green, vigorous foliage; height, 18 inches, producing very beautiful dark green pods from 5 to 6 inches in length, with ten to eleven large wrinkled peas, which are of the most delicious quality. Pkt., 10c; 1b., 30c; 2 lbs., 55c; 10 lbs., \$2.20.

\section{BLISS' ABUNDANCE}

A second early variecy, producing well. filled pods of excellent quality. This variety is remarkable for branching directly from the roots, forming a veritable bush, making it necessary to sow the seeds much thinner than usual; height, 3 feet. Pkt., 10c; lb., 25c; 2 lbs., 50c; 10 lbs., $\$ 2.00$.

\section{DWARF CHAMPION OR JUNO}

An excellent main crop sort, growing about $2 \frac{1}{2}$ feet high. The pods are 4 inches long, straight, broad and square ended, filled with large peas, which are tender and of fine quality. Pkt., 10c; lb., 25c; 2 lbs., 50c; 10 lbs., \$2.00.

\section{DUKE OF ALBANY •}

This English variety is very similar to the famous Telephone. It is a strong grower, about 4 feet in height, very productive. Pkt., 10c; lb., 30c; 2 lbs., 55c; 10 lbs., \$2.20.

\section{LONG ISLAND MAMMOTH OR TELEGRAPH}

A general favorite with the market gar, deners of Long Island and New Jersey, where it is grown very extensively for a main crop for the New York and Philadelphia markets. It produces very large, well-filled pods, which are of a deep green color and of choice qual, ity; height of vines, 4 feet. Pkt., 10c; lb., 30c; 2 lbs., 55c; 10 lbs., \$2.20.

\section{IMPROVED STRATAGEM}

This famous variety cannot be recom. mended too highly, and has become one of our most celebrated and popular varieties; it follows the Premium Gem, and it may be classed with the third early varieties, or those intended for a main crop. It is dwarf, grow. ing but $21 / 2$ feet high, of strong, robust habit, requiring but slight support, enormously productive, peas wrinkled, sweet and of delicious flavor. Pkt., 10c; lb., 30c; 2 lbs., 55c; 10 lbs., $\$ 2.20$.

\section{ALDERMAN}

A splendid large podded variety of excellent quality. Vines vigorous, growing about 4 feet high, with coarse dark colored leaves and producing an abundance of very large, dark green pods, filled with immense peas of delicious flavor. Pkt., 10c; lb., 30c; 2 lbs., 55c; 10 lbs., \$2.20. 


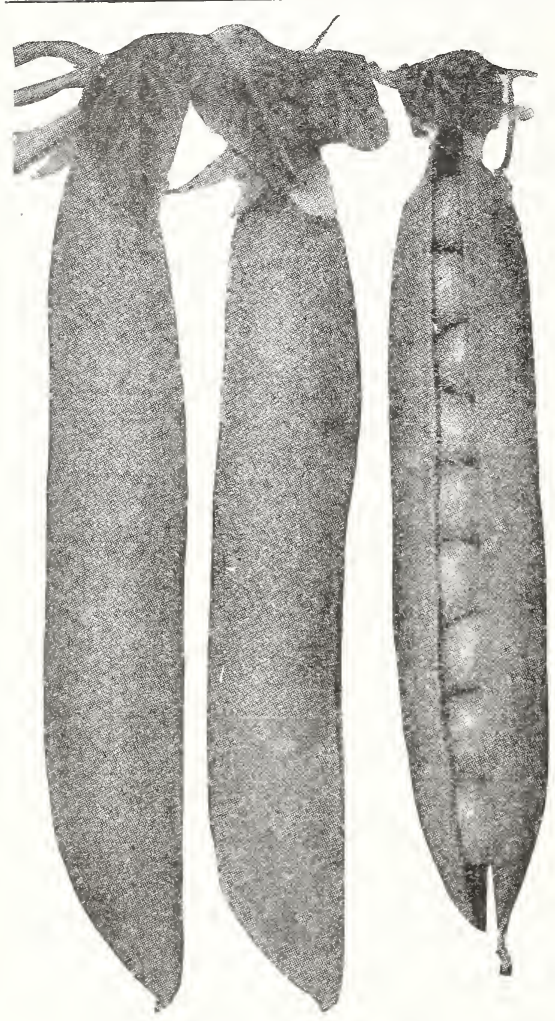

Buist's Improved Telephone Peas

Buist's Improved Telephone-A marvelous variety, producing pods of prodigious size and well filled with mammoth peas of excellent flavor. Growth, 4 feet; an extraordinary cropper. A good main crop Pea; the pods are dark green and much more desirable than the light green of the old type. Recommended for the home garden and shipping. Pkt., 10c.; 1b., 30c.; 2 lbs., 55c.; 10 lbs., $\$ 2.20$.

Black-Eyed Marrowfat-A well known tall, late maturing variety, about 5 feet high. It is a strong grower and very hardy. Where quantity without quality is wanted, plant Marrowfats. Pkt., 10c.; lb., 25c.; 2 lbs., 40c.; 10 lbs., $\$ 1.80$.

Large White Marrowfat-Similar to the Black-Eyed in all its features except growth; it is a strong grower and not quite as productive. Pkt., 10c.; 1b., 25c.; 2 lbs., 40c.; 10 lbs., \$1.80.

Dwarf Sugar (Edible Pods) - This variety can be used either shelled or whole, the pods while young being sweet and tender; seed gray in color. Pkt., 10c.; lb., 30c.; 2 lbs., 55c.; 10 lbs., \$2.20.
The Imperator-The largest podded and heaviest yielding of all main crop sorts. The vines are enormously productive, being completely covered with immense long pods, containing nine to eleven large peas of delicious flavor. Height of vine, $4 \frac{1}{2}$ feet. The pods are a dark green, a decided advantage in a market pea. Quality is superb, rich, sweet, retaining their dark color when cooked. This variety is unexcelled and very desirable for home or market garden. Pkt., 10c.; lb., 30c.; 2 lbs., 55c.; 10 lbs., $\$ 2.20$.

Yankee Prince-A large podded main crop pea, very robust and vigorous. It is a great cropper and fills the basket quickly. Growth, 4 feet; color of pods, dark green. Pkt., 10c.; lb., 30c.; 2 lbs., 55c.; 10 lbs., \$2.20.

Prince Edward-A very large wrinkled pea, producing pods of enormous size. Vine tall, about 5 feet; vigorous and strong grower; pods 5 inches long, straight and thick, of a deep green color. A splendid shipper. Pkt., 10c.; 1b., 30c.; 2 lbs., 55c.; 10 lbs., $\$ 2.20$.

Champion of England-A green wrinkled variety-famous for its delicious flavor, but is a shy bearer; consider it one of the finest varieties for family use, and will follow any of the second early varieties in ripening. Height, 5 feet. Pkt., 10c.; 1b., 25c.; 2 lbs., 50c.; 10 lbs., $\$ 2.00$.

Bliss Everbearing-A wrinkled variety, growing about 2 feet, but of a very distinct habit, producing several vines from the same stem, which continue producing a succession of crops; the peas are of a large size and of fine flavor. Pkt., 10c.; lb., 25c.; 2 lbs., 50c.; 10 lbs., $\$ 2.00$.

Mammoth Luscious Sugar (Edible Pods) -Excels all other Sugar Peas in size, productiveness and quality. The vines grow to a height of 5 feet, producing a profusion of large, broad pods, which are so brittle they snap without any strings. The pods are used when half grown, and are cooked in the same way as Snap Beans; seed gray. Pkt., 10c.; lb., 35c.; 2 lbs., 65c.; 10 lbs., $\$ 250$.

Mammoth Melting Sugar (Edible Pods) -A large-podded variety, producing large, broad pods, which are of the finest flavor and exceedingly tender; height 4 to 5 feet. Prepare them for the table same as Wax Beans; seed smooth and white. Pkt., 10c.; lb., 35c.; 2 lbs., 65c.; 10 lbs., $\$ 2.50$.

Dwarf White Sugar (Edible Pods)-Very productive. Pods light green, $21 / 2$ inches in length; seed white. Height 2 feet. Pkt., 10c.; lb., 30c.; 2 lbs., 55c.; 10 lbs., $\$ 2.20$. 


\section{PEPPER}

Sow early in Spring in a hotbed in shallow drills 6 inches apart. In order to make strong, healthy plants, they should be transplanted, when a few inches high, into another bed, or sow in a warm spot of the garden about the middle of Spring and transplant them, when 2 inches high, in rows $2 \frac{1}{2}$ feet apart and 2 feet in the rows. The Pepper delights in a rich soil.

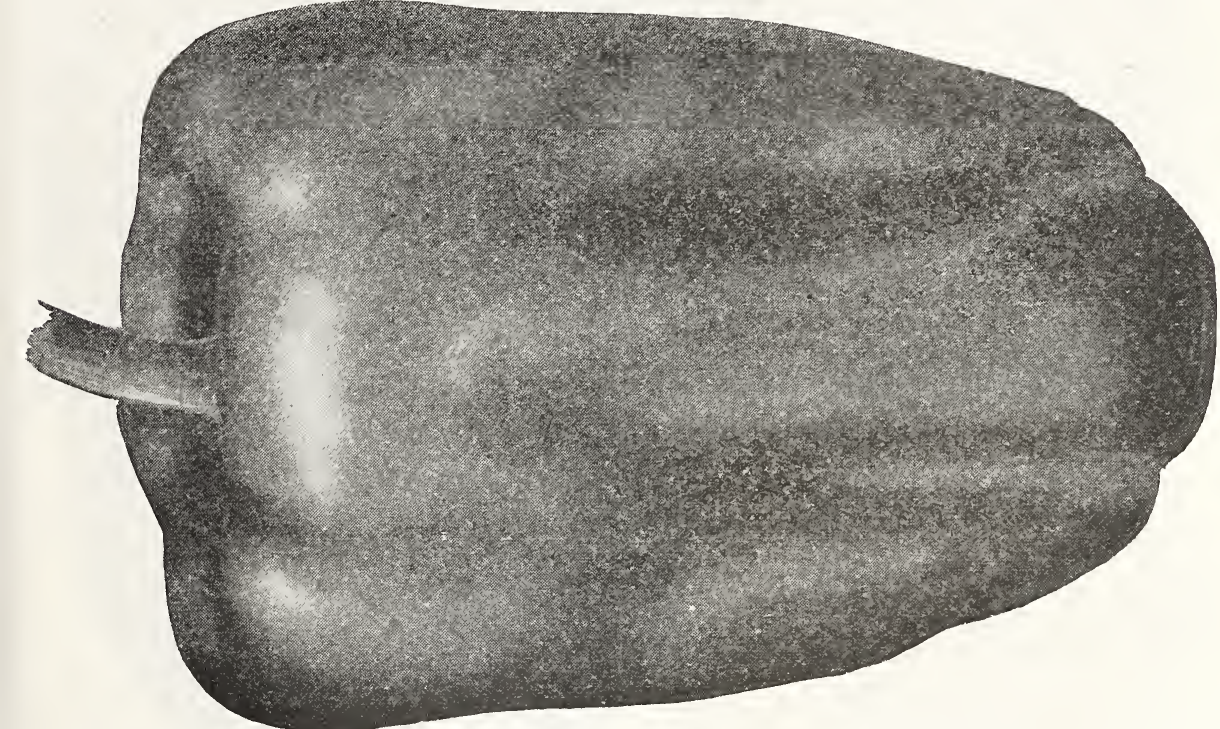

Buist's Selected Ruby King

Ruby King-An exceedingly large and handsome Pepper, of a bright ruby red, from $4 \frac{1}{2}$ to 6 inches long by 9 to 12 inches in circumference. The flesh is exceedingly thick, crisp and tender. Very mild flavor and pleasant to the taste. This variety is cultivated almost exclusively by the large growers of South Jersey. Especially good for mangoes. Our strain is exceedingly fine. Pkt., 10c.; 1/2 oz., 20c.; oz., 35c.; 1/4 lb., $\$ 1.15 ; 1 \mathrm{~b}$., $\$ 4.00$.

Harris' Early Giant-A very desirable variety for market gardeners, as it matures the earliest of all large peppers. The color is deep green when young and a rich red when ripe. Flesh is thick and has a mild pleasant flavor. Very productive. Pkt., 10c.; I/2 oz., 25c.; oz., 45c.; $1 / 4$ lb., $\$ 1.50$; lb., $\$ 5.00$.

Large Bell, or Bull Nose-The standard variety for home use, very hardy and matures early. The fruit is 3 inches long and 3 inches across the top, with thick flesh of somewhat pungent taste. Pkt., 10c.; T/2 oz., 20c.; oz., 30c.; $1 / 4$ lb., $\$ 1.00 ; 1 b ., \$ 3.50$.

Pimiento-This variety is an absolutely sweet Pepper of good size and not only desirable for salads and stuffed peppers, but is also used largely by canners. The flesh is very thick and solid. Pkt, 10c.; 1/2 oz., 15c.; oz., 30c.; 1/4 lb., $\$ 1.00 ;$ lb., $\$ 3.50$.
Ruby Giant, Buist's Selected-This is a cross of Ruby King and Chinese Giant, which has made it a very attractive variety; it grows to a large size, of very handsome appearance. Flesh exceedingly thick, sweet and mild. Splendid for stuffing. The strain that we grow runs uniform and true and is pronounced by market gardeners and shippers to be the finest on the market. Pkt., 10c.; 1/2 oz., 20c.; Oz., 40c.; I/4 lb., $\$ 1.25 ; 1 \mathrm{~b} ., \$ 4.50$.

California Wonder-This new and distinct Pepper possesses many points of excellence. It has the fine quality of the Pimiento and the size of Giant Crimson with a thickness of flesh unknown in any variety of pepper. It is not uncommon to find fruits showing flesh threeeighths of an inch thick. In addition to this it is of the finest quality, being sweet, crisp, tender and entirely free from pungency. Pkt., 10c.; I/2 oz., 35c.; oz., 65c.; $1 / 4$ lb., $\$ 2.25$; lb., $\$ 8.00$.

Royal King-A sweet Pepper of the Ruby King type. The flesh is thick and mild flavored. Especially fine for salads or stuffed for mangoes. Royal King is a heavy bearer; runs remarkably true to type and uniformity of size, making it a very desirable variety for the market gardener and shipper. Pkt., 10c.; $1 / 2$ oz., 20c.; Oz., 35c.; 1/4 lb., \$1.15; lb., $\$ 4.00$. 
World Beater-The fruit of this very desirable variety is of the same shape as the Ruby King, except that it is broader at the pointed end and grows to a larger size. The flesh is unusually thick, sweet and of a mild flavor. The color is a deep green when young, bright scarlet when ripe. It combines the size of the Chinese Giant and the attractive shape and color of the Ruby King. A good sort for market gardeners and shippers. Pkt., 10c.; $1 / 2$ oz., 20c.; Oz., 40c.; I/4 lb., \$1.25; lb., $\$ 4.50$.

Early Neapolitan-A popular market variety on account of its earliness and productiveness. Flesh is thick and exceedingly mild. Fruit grows upright and measures 4 inches long by $4 \mathrm{~T} / 2$ in circumference. Pkt., 10c.; I/2 oz., 15c.; oz., 30c.; I/4 lb., $\$ 1.00$; 1b., $\$ 3.50$.

Sunnybrook Cheese-A tomato shaped Pepper of the Pimiento type, averaging 3 inches in diameter and 2 inches deep. The flesh is very thick, solid, mild and sweet in flavor. Pkt., 10c.; I/2 oz., 20c.; oz., 35c.; I/4 lb., $\$ 1.15 ; 1$ b., $\$ 4.00$.

Tomato, or Squash-Upright growth, fruit small, flat, shaped like a tomato, flesh thick, somewhat pungent. Very early and productive. Pkt., 10c.; 1/2 oz., 15c.; oz., 30c.; I/4 lb., $\$ 1.00$; lb., $\$ 3.50$.

Golden Queen-A very beautiful variety, resembling the Bell in shape and habit, but of a beautiful golden color and of mild flavor. Pkt., 10c.; I/z oz., 20c.; oz., 35c.; $1 / 4$ lb., $\$ 1.15 ; 1$ b., $\$ 4.00$.

Finger Pepper or Long Hot-A thick meated hot pepper. Pods are 5 inches long and $1 \mathrm{x} / 2$ inches in diameter, tapering to a point. Pkt., 10c.; $1 / 2$ oz., 25c.; oz., 45c.; 1/4 lb., \$1.50; 1b., \$5.00.

Large Red Cherry-Very hot, the fruit average $1 \mathrm{I} / 2$ inches in diameter. Used extensively by pickling houses and canners. Pkt., 10c.; 1/2 oz., 25c.; oz., 45c.; I $/ 4$ lb., $\$ 1.50 ; 1$ b., $\$ 5.00$.

Small Red Cherry-A small, round variety, of dwarf habit and a rich scarlet color, used for seasoning and pickling. Very hot. Pkt., 10c.; I/2 oz., 20c.; oz., 30c.; I/4 lb., $\$ 1.00 ;$ lb., $\$ 3.50$.

Red Chili-A rather small, bright red variety, about 2 inches long and pointed. Pods hot, used for seasoning and pepper sauce. Pkt., 10c.; I/2 oz., 20c.; oz., 30c.; 1/4 1b., $\$ 1.00$; 1b., $\$ 3.50$.

Chinese Giant-This is the largest variety known, monstrous in size and beautiful in appearance, of a brilliant glossy scarlet color, from 4 to 5 inches broad and of equal length, and as sweet as an apple; flesh thick, tender and mild; undoubtedly one of the greatest acquisitions to the list of vegetable fruits. Pkt., 10c.; $1 / 2$ oz., 25c.; oz., 50c.; $1 / 4$ 1b., $\$ 1.75$; 1b., $\$ 6.00$.

Tabasco-"Hottest of All"-Tall bush growth, producing a number of small, slender pods; extremely hot and fiery in flavor; 1 inch in length. The wellknown "Tabasco Sauce" is made from this variety. Pkt., 10c.; I/2 oz., 25c.; oz., 45c.; $1 / 4$ lb., $\$ 1.50$; 1b., $\$ 5.00$.

Giant Long Red Cayenne-Produces peppers 6 to 7 inches long and 1 inch thick at the shoulder, tapering gradually; agreeably pungent. Grown for use in Chili Con Carne and for seasoning when dried. Pkt., 10c.; 1/2 oz., 20c.; oz., 40c.; $1 / 4$ lb., $\$ 1.25$; lb., $\$ 4.50$.

Long Red Cayenne-The pods are narrow, about $1 / 4$ inch thick and 3 to 4 inches long, they are borne in great abundance; very hot in flavor. Pkt., 10c.; $1 / 2$ oz., 20c.; oz., 35c.; $1 / 4$ lb., $\$ 1.15$; lb., $\$ 4.00$. 


\section{BUIST'S Selected SEED POTATOES}

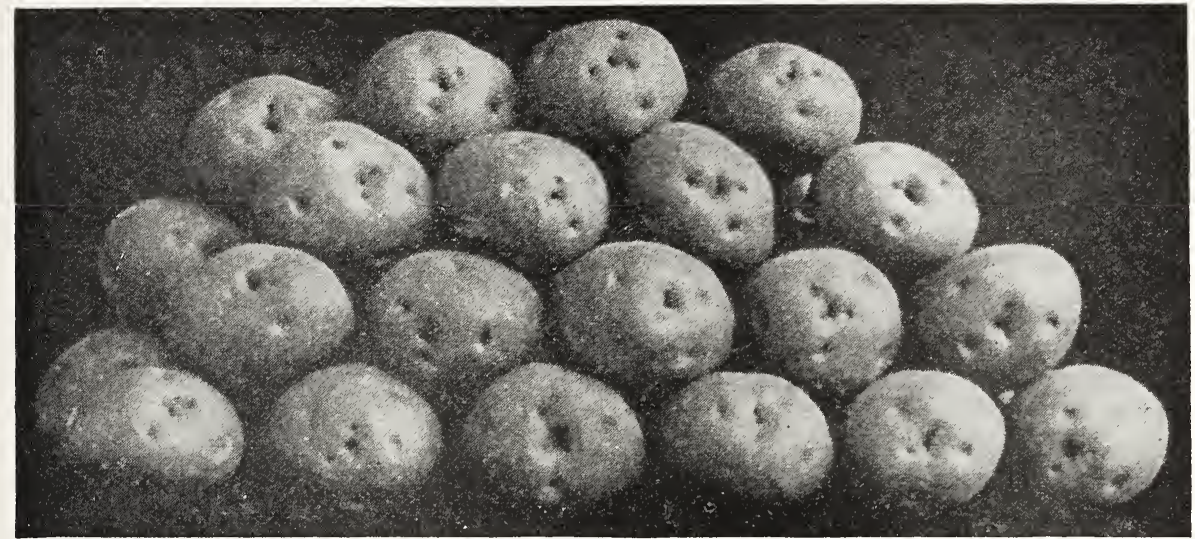

Irish Cobbler Potatoes

Potato market unsettled, write us for prices stating variety and quantity wanted and we will be pleased to make quotations. Potatoes are ready for shipment about March 1st.

Irish Cobbler-The most profitable variety to grow for early market; thousands of acres are annually grown by the potato growers of Southern New Jersey, which is regarded by them as the most productive and profitable to grow for their first shipments; produces few, if any, small potatoes and all of marketable size. Flesh is pure white, with a smooth, clear, white skin. Eyes deep, always cooks dry and mealy; splendid keeper. We recommend it highly to all potato growers.

Presque Island Early Rose-We grow our finest stock of Early Rose at Presque Isle, which is one of the famous locations in Maine for raising Potatoes; the deep, rich soil and favorable climate is especially adapted to their growth; the Potatoes are always handsome in their appearance, having almost a transparent, thin, pink skin. Stock of this kind will always produce crops of fine quality in any State if the season is at all favorable.
Houlton Early Rose-The Houlton stock of Early Rose, when strictly pure, is regarded as the earliest and most desirable stock for planting. They are from Houlton, Me., and are always of a bright color, thin skin and of perfect form.

Bliss Early Red Triumph-This beautiful variety combines the productiveness of the Carman with the good qualities of the Early Rose; it is an extra early variety, the tubers are of medium size, round and uniform in shape, eyes slightly depressed, color a beautiful light red. Its great beauty, productiveness and fine quality make it one of the best extra early market varieties, especially for the South, where it is a very great favorite.

Early Ohio-A seedling of the Rose, resembling it in color of a rounded oblong shape; it is of fine quality, about a week earlier than the Rose, is a good yielder and one of the very finest varieties for the table. Quality dry and mealy.

Buist's Early Sunrise-A variety possessing extreme earliness and great productiveness, producing Potatoes fit for the table in fiftytwo days from time of planting. The tubers are oblong, large, solid, uniform and handsome; flesh white, fine-grained and dry, cooking well, even when first dug; very productive and of fine keeping qualities. A splendid variety for the home garden.

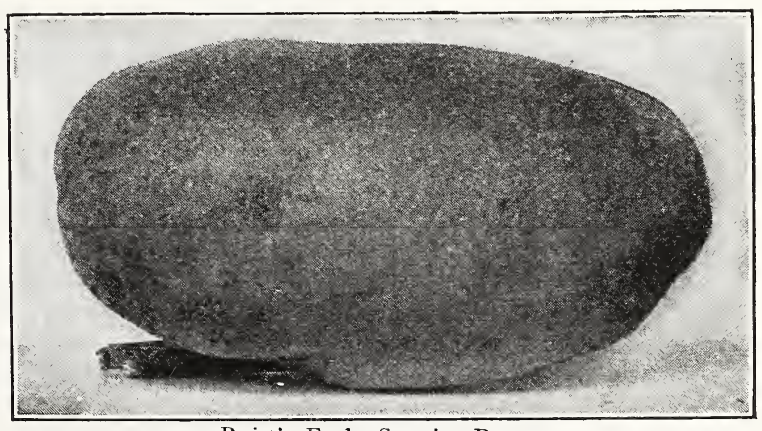

Buist's Early Sunrise Potato 


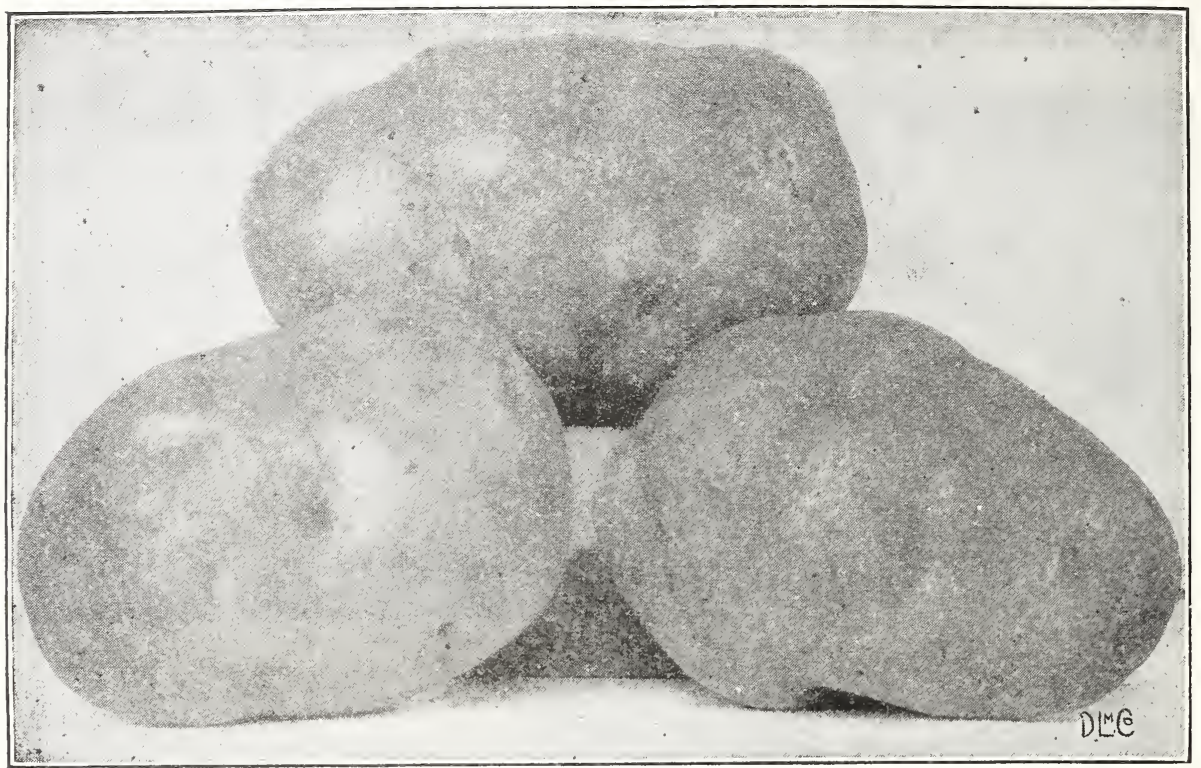

Green Mountain Potatoes

\section{EARLY BEAUTY OF HEBRON}

One of the best of the early varieties. In some sections it proves earlier than the Early Rose; vine vigorous, growing very rapidly; very productive. Tubers similar in shape to the Early Rose, skin tinged with pink, flesh pure white of the finest quality.

\section{RUSSET}

A reliable late variety, heavy cropper and a strong grower. Immune to rust and blight, and of excellent quality.

\section{SIR WALTER RALEIGH}

A very profitable main crop potato, the tubers are oblong; white, very smooth and of uniform size; highly recommended for great productiveness and unsurpassed keeping qualities.

\section{STATE OF MAINE}

A large, oval and slightly flattened pure white variety, medium early, very productive, good flavor, cooks dry and a good keeper. One of the very best varieties for Fall and Winter use.

\section{SPAULDING'S No. 4 ROSE}

A comparatively new variety, similar in shape to the Early Rose, except that it is smoother and somewhat flatter and not so early, but a larger and better shipping variety. Especially desirable to growers and shippers.

\section{GREEN MOUNTAIN}

This is the most popular late variety, in some sections it has superseded all other main crop varieties. It is oval in shape, large in size, white skin and a great cropper; it produces very few small potatoes, cooks white, dry and mealy, thrives in any soil and in all localities; highly recommended.

\section{GOLD COIN}

A main crop variety of remarkable pro. ductiveness and finest table quality, its form is oblong, flesh white, and grows to a large size.

\section{JERSEY RED SKIN}

A variety that is very popular with the farmers of South Jersey for late planting, the past season we were unable to supply the local demand. They were planted late in June and early July and have never failed to make a crop, a strong grower, very productive and not subject to blight. Its form is oblong, skin red, flesh white, cooks very dry and is the best of all Winter keepers. Orders booked now for shipment after June 1st.

\section{RURAL NEW YORKER No. 2}

$A$ very vigorous grower. A valuable variety of large size, very smooth, a great cropper and of excellent quality. The tubers grow extremely solid, making a splendid keeper.

\section{The Potato market is unsettled at time of this catalogue going to press and unable} to name prices. Kindly write, stating kind and quantity wanted and we will be pleased to make quotations. Potatoes are ready for shipment about March 1st. 


\section{PUMPKIN}

$\mathrm{P}$ LANT in May, after the ground is warm, in hills 8 to 10 feet apart each way, as the vines require plenty of room to ramble. A good practice is to plant every fifth hill and every fifth row in the corn field. Avoid planting near other vines. As soon as the plants appear above the ground, dust with air-slacked lime or land plaster mixed with dry soil or ashes to control the striped beetle. One ounce will plant twenty-five hills, four pounds per acre.

\section{MAMMOTH GOLDEN CUSHAW}

This is the best of all varieties for pies and custards, and also for feeding purposes. It grows to a large size, with crooked neck; of a beautiful yellow color when matured; flesh is thicker, more solid, sweeter and finer grained than any other variety. Pkt., 10c; oz., 15c; $1 / 4 \mathrm{lb}$., 40c; lb., \$1.25.

\section{WINTER LUXURY}

A superior pie pumpkin, shape slightly oval, color golden russet, flesh deep golden yellow, sweet flavored. Used for making jack-o-lanterns. Pkt., 5c; oz., 10c; 1/4 lb., 30c; lb., $\$ 1.00$.

\section{LARGE SWEET CHEESE}

Has heavy thick, sweet meat; large round, flattened variety, with creamy-buff skin. An excellent keeper and very productive; good quality. Best for canning. Pkt., 5c; oz., 10c; $1 / 4$ lb., 25c; lb., 75c.

\section{QUAKER PIE}

A very distinct and desirable variety for custards or pies. It is of a peculiar shape, and unlike any other variety, being oval and tapering towards each end, and of a creamy color both inside and out; flesh of fine grain, rich flavored and a good keeper; is entirely free from that coarse and stringy character so common to many varieties. Pkt., 5c; oz., 10c; $1 / 4$ lb., 30c; lb., \$1.00.

\section{SUGAR, OR PIE}

A rather small, but handsome variety. Shape round, skin deep orange-colored; flesh fine-grained, sweet flavored; superior for pies. Pkt., 5c; oz., 10c; 1/4 lb., 30c; lb., \$1.00.

\section{TENNESSEE SWEET POTATO}

Bell shape; medium size, thick flesh, skin creamy white, fine grained, sweet, delicious. Very fine for pies. Pkt., 5c; oz., 10c; 1/4 lb., $30 \mathrm{c} ; 1 \mathrm{lb} ., \$ 1.00$.

\section{JAPANESE PIE}

Crooked neck; quality fine; very produc. tive; ripens early; medium size. Excellent for pies. Pkt., 5c; oz., 10c; 1/4 lb., 30c; lb., \$1.00.

\section{MAMMOTH KING, OR KING OF MAMMOTHS}

Also called "Jumbo" because of the size of the Pumpkins it produces, which frequently weigh 100 pounds. The skin is a bright lemon color, mottled with orange, shape round and flattened, slightly ribbed. The flesh is thick, hard and of good quality. Pkt., 10c; oz., 15c; 1/4 lb., 50c; lb., \$1.50.

\section{CONNECTICUT FIELD}

Generally used for planting in cornfields for stock feeding, but it also makes good pies. Pkt., 5c; oz., 10c; 1/4 lb., 30c; lb., 80c.

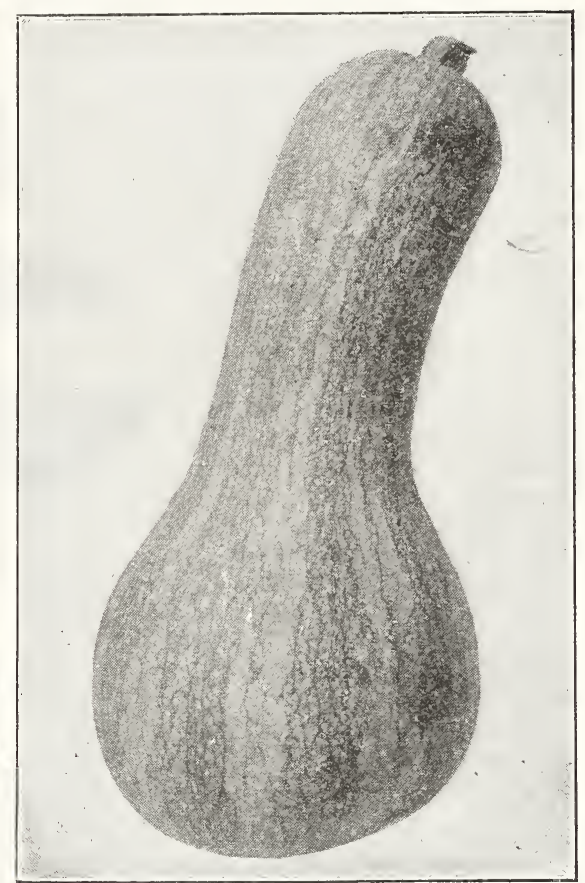

Green Striped Cushaw Pumpkin

GREEN STRIPED CUSHAW

Fruits very large, with crooked neck; color creamy white, irregularly striped or traced with green. Flesh light yellow, very thick; sweet. Very productive and popular in the Southern States. Pkt., 10c; oz., 15c; 1/4 lb., $40 \mathrm{c}$; lib., \$1.25.

\section{MAMMOTH FIELD, OR BIG TOM}

This is one of the largest, most uniform growing and productive varieties known; it has been produced by an annual selection being made for a number of years from the old Golden Marrow by one of the largest canning establishments in Ohio, and who an. nually grow hundreds of acres especially for canning; they say that they can find no variety equal to it for this purpose: Pkt., 5c; oz., 10c; 1/4 lb., 30c; lb., 80c.

\section{KENTUCKY FIELD}

Cultivated by our farmers in their cornfield, for stock feeding, making enormous crops. Pkt., 5c; oz., 10c; 14 lb., 25c; 1b., 75c.

\section{GOLDEN OBLONG}

The skin is rich yellow, flesh light yellow and of finest flavor. Grows 15 to 20 inches long and about 8 to 10 inches in diameter. Pkt., 5c; oz., 10c; 1/4 lb., 30c; lb., 80c. 


\section{RADISH}

RADISH should be sown in light, rich and finely pulverized soil, as their tenderness R depends on the rapidity of their growth. Sow thinly as soon as the ground is dry in the spring in rows eight to twelve inches apart and thin out to prevent crowding. For a succession sow every ten days up to the middle of June. The quick maturing varieties may be sown between rows of Beets or Carrots. Winter Radishes may be sown in July or later and allowed to develop in the cool, moist fall weather. They may be stored like Turnips for winter use.

\section{BUIST'S TRUCKERS “EARLY MONEY”}

This variety has a small top, and is the earliest in cultivation; the roots are small, of a rich, bright scarlet color, and the handsomest of all forcing varieties; ready to pull in three weeks. The leaves are short, which per. mits of close sowing. The best and most satisfactory for home garden, and the market gardeners will find it a great money. maker. Pkt., 5c; 1/2 oz., 10c; oz., $15 \mathrm{c} ; 1 / 4 \mathrm{lb}$., 40c; lb., \$1.25.

\section{EARLY DEEP SCARLET TURNIP}

One of the most desirable early varieties for either market or private gardens; small in size, globular in form and of a rich color; tops small and of very rapid growth. Pkt., 5c; oz., 10c; 1/4 lb., 30c; lb., $90 \mathrm{c}$.

\section{GLOWING BALL}

A very attractive early forcing variety; ready for the table within three weeks from sowing. Color a brilliant fiery scarlet-red, perfectly round, with small top and thread. like tap roots. Flesh is pure white, tender and exceedingly delicate in flavor. Glowing Ball is suitable both for forcing under glass and for Spring and Fall sowing in the open ground. Pkt., 10c; oz., 15c; 1/4 lb., 50c; lb., $\$ 1.50$.

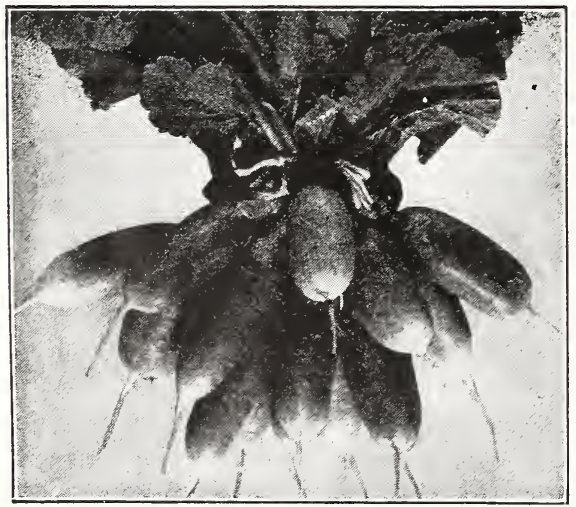

French Breakfast Radish

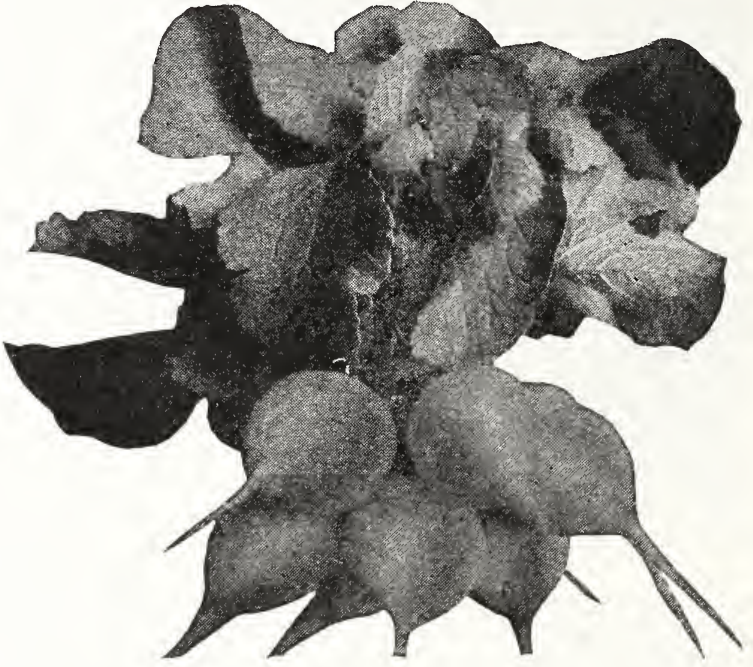

Buist's Truckers "Early Money" Radish

\section{BUIST'S SELECTED SCARLET GLOBE}

This variety is a selection of the Scarlet Globe and famous for its extreme earliness, its brilliancy of color, and for its perfect form. It is the stock used by the leading gardeners for forcing, and for which purpose it excels all others, as its great beauty makes it a quick seller. Pkt., 5c; oz., 10c; 1/4 lb., 30c; lb., $\$ 1.00$.

\section{EARLY SCARLET WHITE-TIPPED TURNIP}

A beautiful scarlet variety, of handsome shape, having a white-tipped tail or root, very desirable. Flesh is white and of best quality. One of the most popular and salable varieties. Pkt., 5c; oz., 10c; 1/4 lb., 30c; lb., 90c.

\section{BUIST'S EARLIEST SCARLET TURNIP OR SCARLET BUTTON}

A very beautiful variety and a general favorite; of a brilliant scarlet color, and is adapted for either forcing or for early sowing in the garden, but will not stand the heat; it can also be sown early in the Fall for late crop. Pkt., 5c; oz., 15c; $1 / 4$ lb., 40c; lb., $\$ 1.25$.

\section{RAPID RED OR SAXA}

One of the earliest of all the Scarlet Turnip varieties; very tender and crisp; rich scarlet color. An excellent forcing sort. Pkt., 5c; oz., 10c; 1/4 lb., 30c; lb., \$1.00. 


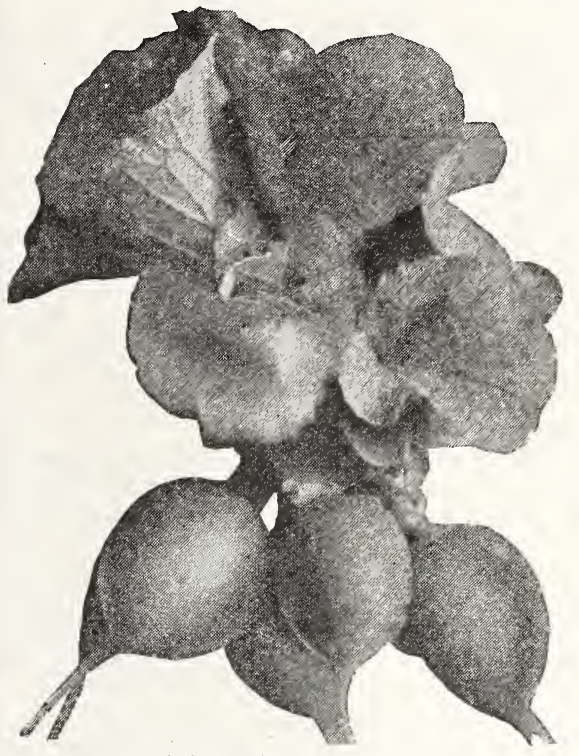

Buist's Scarlet Globe Radish

EARLY WHITE BOX

This is one of the very best varieties for either forcing, cold-frame culture, or for early sowing in the open ground. They are of the most perfect form, of a paper-white color, very mild, of pleasant flavor and very early. Pkt., 5c; oz., 10c; 1/4 lb., 30c. lb., \$1.00.

\section{CRIMSON GIANT}

An entirely new type of turnip-shaped Radish, double the size of other early sorts; color crimson, flesh pure white. Very desir. able for outdoor planting, also for forcing when a very large round radish is wanted. It remains in condition a long time for so early a variety. Pkt., 5c; oz., 10c: 1/4 lb., 30c; lb., \$1.00.

\section{THE LIGHTNING SCARLET FORCING}

This is a very early forcing variety, ready for the table within three weeks from sowing; of turnip shape, of a bright scarlet color; flesh tender and exceedingly delicate in flavor. Pkt., 5c; oz., 10c; 1/4 lb., 30c; lb., \$1.00.

\section{EARLY HALF-LONG SCARLET FRENCH}

A very popular variety among the French and Germans; is of a half-long shape; bright scarlet color, and well adapted for either forcing or for early sowing in the garden. Pkt., 5c; oz., 10c; 1/4 lb., 30c; lb., \$1.00.

\section{SAKURAJIMA, MAMMOTH JAPAN}

This is a giant variety of radish from Japan. It has been grown to the enormous dimensions of 43 inches in circumference. Flesh is solid, firm and brittle, and of excellent flavor. Sow in rich soil and thin out. Pkt., 5c; 1/2 oz., 10c; oz., 15c; $1 / 4$ lb., 50c; lb., \$1.50.

\section{EARLY FRENCH BREAKFAST}

A very popular French variety of very rapid growth, and one of the best varieties for early forcing; its form is oval, color scarlet tipped with white, and small in size. It is also a beautiful variety for garnishing pur. poses. Pkt., 5c; oz., 10c; 14 lb., 30c; lb., $\$ 1.00$.

\section{LONG VARIETIES}

\section{BUIST'S LONG SCARLET}

This improved strain of Long Scarlet Radish is regarded by our most extensive market gardeners to be the finest stock they ever grew; for earliness, brilliancy of color and shortness of top it cannot be surpassed, and it is the most profitable to grow for an early crop. Very desirable for early forcing, or first sowing in the garden, it is of a bright scarlet color, very tender and brittle. Pkt., 5c; oz., 10c; 1/4 lb., 30c; lb., \$1.00.

\section{THE CINCINNATI MARKET}

This is another selection of the Long Scarlet, with exceedingly small tops, and grows from six to seven inches long; of a beautiful bright scarlet color, with a very delicate skin; one of the best and most attractive market varieties. Pkt., 5c; oz., 10c; 1/4 lb., 30c; lb., \$1.00.

\section{LONG BRIGHTEST SCARLET}

This beautiful and valuable variety was in. troduced from France, and is the earliest variety of the Long Scarlet class; color of brightest scarlet; of long, thin shape, beautifully tipped with white. Pkt., 5c; oz., 10c; $1 / 4$ lb., 30c; lb., \$1.00.

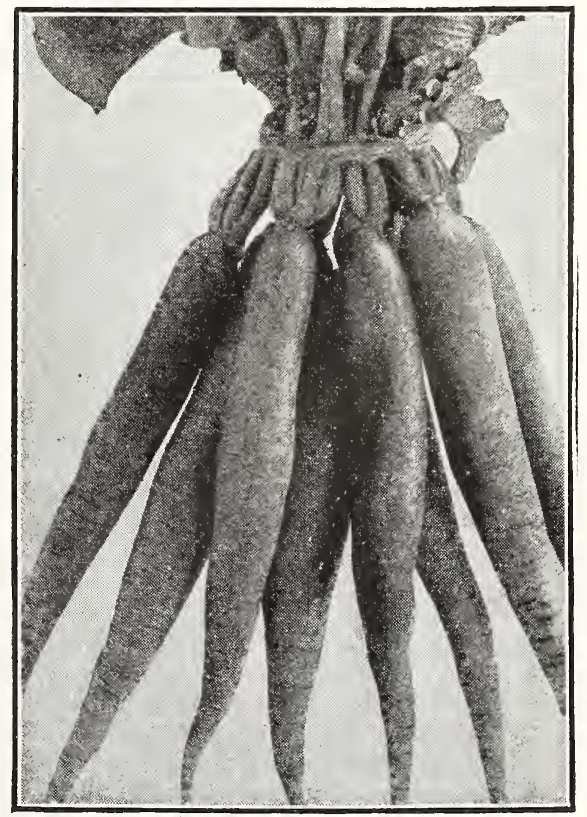

Early Long Scarlet Radiab 


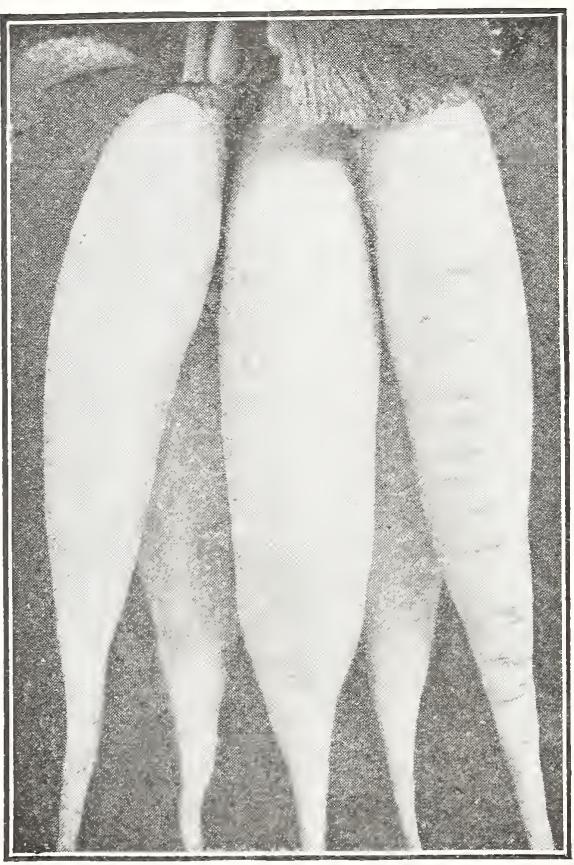

Long White Icicle Radish

Long White Icicle-This is the most beautiful of the early long white varieties; of a pearly white color; fine for either forcing or out-door culture. The roots are of slender form, crisp and tender, even when fully developed and of delicate flavor. One of the best varieties for outdoor Summer planting for the home garden and market. Pkt., 5c.; oz., 10c.; 1/4 1b., 30c.; 1b., $\$ 1.00$.

White Summer Strasburg-This is a very desirable early Summer variety, of an oblong tapering shape, and of pure white color; is exceedingly crisp and tender. It forms its roots very quickly, and can be sown throughout the Summer; both flesh and skin are pure snow white, crisp and tender and of very rapid growth. Pkt., 5c.; oz., 10c.; I/4 lb., 30c.; 1b., \$1.00.

Improved Chartier or Shepherd-One of the most distinct varieties; color scarlet at top, shaded to pink at center and white at tip; they will keep crisp, tender and retain a mild and pleasant flavor for a long time. Pkt., 5c.; oz., 10c.; $1 / 4$ lb., 30c.; lb., $\$ 1.00$.

Long White Vienna or Lady FingerOne of the finest varieties of this class; skin pure white. Very early, mild and tender, and of the length of the Long Scarlet; stands the heat remarkably well. Pkt., 5c.; oz., 10c.; 1/4 1b., 30c.; lb., $\$ 1.00$.
Buist's Early Long White-A selection made from the Early White Vienna; in form it is more perfect; of a whiter shade of color and a week earlier. Pkt., 5c.; oz., 10c.; 1/4 lb., 30c.; lb., $\$ 1.00$.

Giant White Stuttgart-A popular variety, very early and of quick growth. It is globular in shape; skin and flesh pure white, and withstands the heat splendidly; grows to a very large size, but is always juicy, crisp and tender. Pkt., 5c.; oz., 10c.; I/4 1b., 30c.; lb., \$1.00.

\section{WINTER VARIETIES}

Round Scarlet China or All Seasons-A perfectly round Radish of a rich scarlet color that may be sown in Spring, Summer or Fall, retaining its sweetness and solidity when other sorts are pithy and useless. As a Winter sort it has the same fine qualities as the Chinese Rose. Matures in six weeks. Pkt., 5c.; 1/2 oz., 10c.; oz., 15c.; 1/4 lb., 40c.; lb., \$1.25.

Long Black Spanish-One of the latest and hardiest long Radishes, especially adapted for Winter use. Thick, almost black, with white flesh of firm texture. Pkt., 5c.; oz., 10c.; I/4 lb., 30c.; lb., \$1.00.

Half Long Black Spanish-Roots about 5 inches long and 2 inches in diameter. Skin black, flesh is white, firm, crisp, pungent, and of fine flavor. Pkt., 5c.; oz., 10c.; 1/4 lb., 30c.; lb., \$1.00.

Celestial or White Chinese-This is the largest and finest of the Chinese varieties; they grow to a very large size, from 12 to 15 inches long and 5 inches in diameter, and mostly above ground; the roots are shaded by its heavy foliage, and are always crisp and mild. A very desirable variety for Fall and Winter. Pkt., 5c.; Oz., 10c.; I/4 lb., 30c.; lb., $\$ 1.00$.

Chinese Rose-This variety is of halflong shape, pink color, and flesh as solid as an apple; it has not that strong flavor, which is peculiar to the Black Spanish, and keeps equally as well; it should be sown in August. Pkt., 5c.; oz., 10c.; I/4 lb., 30c.; lb., \$1.00.

Round Black Spanish-This Radish grows to a fair size, is round in shape, and considered excellent for Winter use. Skin black, flesh white, highly flavored. Good keeper. Pkt., 5c.; oz., 10c.; 1/4 lb., 30c.; 1b., $\$ 1.00$.

California Mammoth White-Roots white and when fully matured 9 to 12 inches long by 3 to 4 inches in diameter just below the shoulder, tapering regularly to the tip. Flesh firm, crisp, decidedly pungent but well flavored, keeping well through the Winter. Pkt., 5c.; 1/2 oz., 10c.; Oz., 15c.; I/4 1b., 40c.; 1b., \$1.25. 


\section{RHUBARB}

$\mathrm{V}$

ERY familiarly known as the Pieplant. Sow the seed early in the Spring, in rows one foot apart, on rich ground; the second year after planting they can be removed in Autumn to the permanent spot allotted for them; plant the roots 3 feet apart each way, in ground that is well enriched and give a dressing of coarse manure every Spring.

\section{VICTORIA}

A popular variety, producing large, thick stalks of rich red color. Pkt., 10c; oz., 20c; $1 / 4 \mathrm{lb} ., 60 \mathrm{c} ; \mathrm{lb} ., \$ 2.00$.

\section{RHUBARB ROOTS}

Strong roots. Postpaid, each 15c; doz., $\$ 1.50$. By express or freight, each $10 \mathrm{c}$; doz., $\$ 1.00 ; 100, \$ 6.00$.

\section{SORREL}

Sorrel is cultivated for its leaves, which possess a fine flavor when boiled and served like spinach, and is also used for soups. Sow in the Spring in drills 18 inches apart, in a rich soil, and keep the flower stems cut off as they appear.

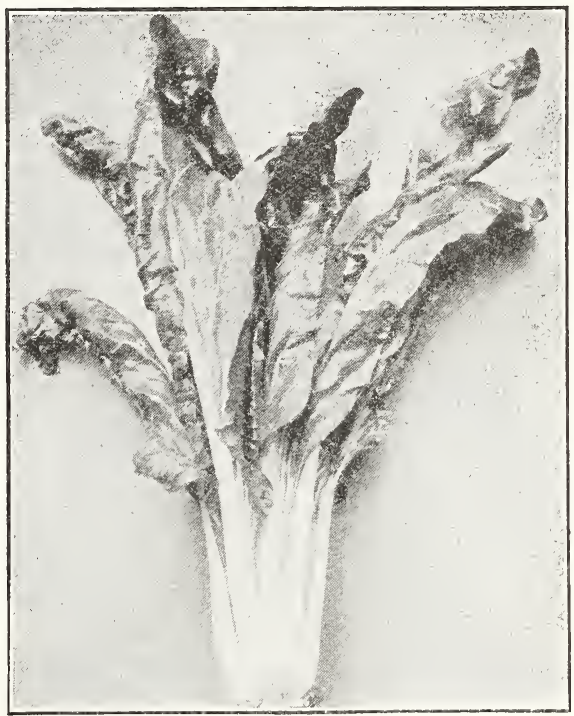

Swiss Chard

Broad-Leaved French-The best garden variety, having large, pale green leaves of fine quality. Pkt., 10c; oz., 20c; 1/4 lb., 60c; lb., \$2.00.

\section{SWISS CHARD OR SPINACH BEET}

This is a Beet producing leaves only and of a quality superior to the ordinary Beet tops. Nothing in the garden requires less care and yet it will yield a constant crop from July to Winter. Sow early in Spring, in rows 16 inches apart and thin to 6 inches in the rows. The stalks are as thick as Rhubarb and are delicious when cooked and served as Asparagus. The leafy portion is cooked and served as Spinach. Good cultivation will greatly increase the delicacy and tenderness of the leaves. Also called "Cut and Come Again Spinach."

\section{GIANT LUCULLUS}

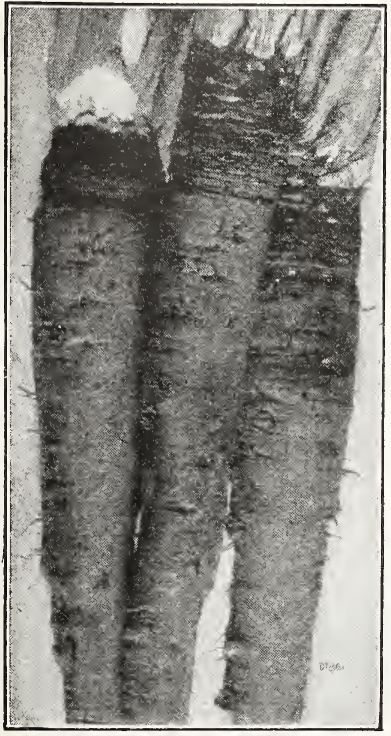

Buist's Mammoth Salsify
The largest variety, leaves crinkled with thick light colored midribs, tender and of fine flavor. Pkto, 5c; oz., 10 c; 1/4 lb., 30c; lb., \$1.00.

\section{LARGE RIBBED}

Large broad green leaves with white stems. Pkto, 5c; oz., 10c; 1/4 lb., 30c; lb., \$1.00.

\section{SALSIFY or VEGETABLE OYSTER}

Very generally known as the Oyster Plant; the roots are boiled like Carrots or Parsnips or half boiled and grated fine, made into small flat balls, dipped in a batter and fried like oysters, of which their flavor greatly partakes. Sow the seed in drills 8 inches apart, and when up, thin them out to 3 inches apart in the row; those for Winter use should be taken up before severe frost, and stored the same as Carrots and Parsnips.

\section{BUIST'S MAMMOTH}

This variety is a great improvement over the Sandwich Island; the roots are very much larger in size, less stringy in its nature and of more delicate flavor; it is the most profitable market variety. Pkt., 10c; 1/2 oz., 15c; oz., 25c; $1 / 4 \mathrm{lb} ., 75 \mathrm{c} ; \mathrm{lb} ., \$ 2.50$.

\section{MAMMOTH SANDWICH ISLAND}

A variety introduced from the Sandwich Islands, cele brated for being much larger in size than the old White French, and has entirely superseded that variety. Pkt., 10c; oz., 20c; 1/4 lb., 65c; lb., \$2.25. 


\section{SPINACH}

CPINACH delights in very rich soil, the richer the better. Sow very early in the Spring one-half inch deep in drills 12 inches apart, and thin the young plants to 4 inches apart in the rows. For a succession, plant every ten days until the end of April. Spinach delights in cool moist weather and quickly runs to seed in hot weather. For a Fall crop sow in August, and for a Winter crop sow in September. In the south-for a Spring crop sow in January, February and March and for a Fall crop sow in September and October. One ounce will sow 100 feet of drill, four pounds per acre.

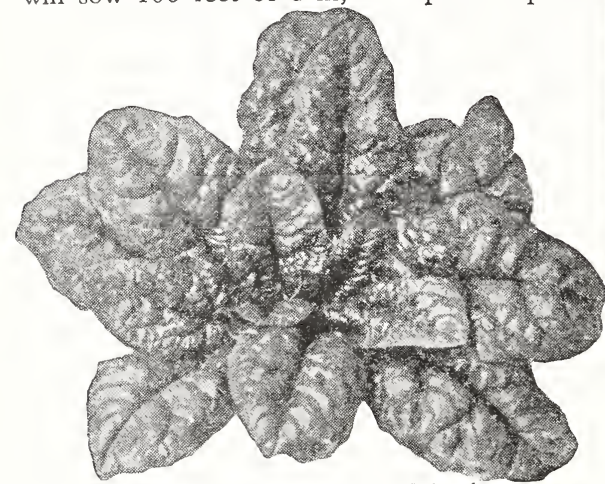

Buist's Perfection Curled Spinach

\section{BUIST'S PERFECTION CURLED}

This variety has reached its present high standard from repeated selections of most perfect curled plants. It is a strain that produces a strong growth of leaves, which are more curled, crimped or blistered than any other variety. It possesses all the perfection that could be desired by a market gardener in a Spinach for a popular and profitable crop. Pkt., 5c; oz., 10c; 1/4 lb., 20c; lb., 50c; 10 lbs., $\$ 3.50$.

\section{BLOOMSDALE SAYOY LEAVED}

This is an old and well-known variety which is exceedingly popular in all sections of this country, and is especially recom. mended for early Winter use; the leaves are beautifully crimped or blistered and of a very dark green color. Pkt., 5c; oz., 10c; 1/4 lb., 20c; lb., 45c; 10 lbs., \$3.25.

\section{PRINCESS JULIANA}

A new type of long season Spinach suitable for Summer and Autumn planting. The leaves are broad, heavy, and of a dark green color. A good variety to sow for a second crop in the Spring. Pkt., 5c; oz., 10c; $1 / 4$ lb., 20c; lb., 45c; 10 lbs., \$3.25.

\section{GIANT LEAVED NOBEL}

Superior to other giant thick leaved varieties in size and long-standing habit. Leaves are large, broad, thick and slightly crimped. Pkt., 5c; oz., 10c; 1/4 lb., 20c; lb., $45 c ; 10$ lbs., \$3.25.

\section{KING OF DENMARK}

A fine long season sort, leaves are extra large, crumpled and blistered, and of a rich dark green color. It retains its fresh, luxuriant appearance for two weeks after other varieties have gone to seed. Pkt., 5c; oz., 10c; $1 \frac{1}{4} \mathrm{lb}$., 20c; lb., 50c; 10 lbs., $\$ 3.50$.

\section{LONG STANDING BLOOMSDALE}

The important feature of this strain is that it will remain in condition for use ten days longer than the regular stock of Bloomsdale before bolting to seed, and for that reason it is especially recommended for Spring sowing. It is also more heavily crumpled and a darker green. Pkt., 5c; oz., 10c; 1/4 lb., 20c; lb., 50c; 10 lbs., $\$ 3.50$.

\section{LONG SEASONS}

This variety is one of the best for Spring and Summer planting, as it remains in perfect condition for a long time before going to seed. The leaves are short, broad, very thick and do not wilt soon in hot weather; they also retain their freshness after cutting. Pkt., 5c; oz., 10c; 1/4 lb., 20c; lb., 45c; 10 lbs., \$3.25.

\section{NEW ZEALAND}

This is a variety that thrives during the hot Summer months when all other Spinach does so poorly. The tender shoots are of good quality and may be cut throughout the Sum. mer season. Pkt., 5c; oz., 10c; 1/4 lb., 25c; lb., 75c.

\section{EARLY GIANT THICK-LEAVED}

A very rapid grower, wtih large, thick, deep green fleshy leaves; slow to seed and very hardy. Highly recommended for early Spring sowing for home garden as well as market. Pkt., 5c; oz., 10c; 1/4 lb., 20c; lb., 40c; 10 lbs., $\$ 3.00$.

\section{NORFOLK BLIGHT-RESISTANT}

Extensively grown in the vicinity of Nor. folk and Portsmouth. It is recommended only for Fall planting, as it has a decided tendency to shoot to seed quickly. Pkt., 5c; oz., 10c; 1/4 lb., 20c; lb., 45c; 10 lbs., \$3.25.

\section{VICTORIA}

This is a late variety of the deepest green color, heavily crimped with thick fleshy leaves, with a deep red stem; and is exten. sively used by market gardeners. Pkt., 5c; oz., 10c; 1/4 lb., 20c; lb., 45c; 10 lbs., \$3.25.

\section{FROST PROOF}

This variety will stand the severest Winter with only a slight protection of straw or leaves. A vigorous grower, recommended for Fall sowing. Pkt., 5c; oz., 10c; 1/4 lb., 20c: lb., 45c; 10 lbs., \$3.25.

\section{BROAD-LEAVED FLANDERS}

This is a strong growing variety, producing large, broad, thick leaves. Popular with the gardeners of Louisiana. Pkt., 5c; oz., 10c; $1 / 4$ lb., 20c; lb., 40c; 10 lbs., $\$ 3.00$. 


\section{SQUASH}

A S SQUASH plants are tender and sensitive to cold, do not plant until the ground is warm. A The bush varieties should be planted in hills 4 to 5 feet apart each way and the Winter sorts 10 to 12 feet apart each way. Thin out to three plants per hill. As soon as they appear above the ground, dust with air-slacked lime or tobacco dust to control insect attacks and repeat as often as the bugs appear until the plants are well established. For yellow-striped beetle and blight spray often with Bordeaux Arsenate of Lead. Sow one ounce for twenty-five hills or four pounds per acre for Summer squash and one ounce to ten hills, or three pounds per acre for Winter squash.

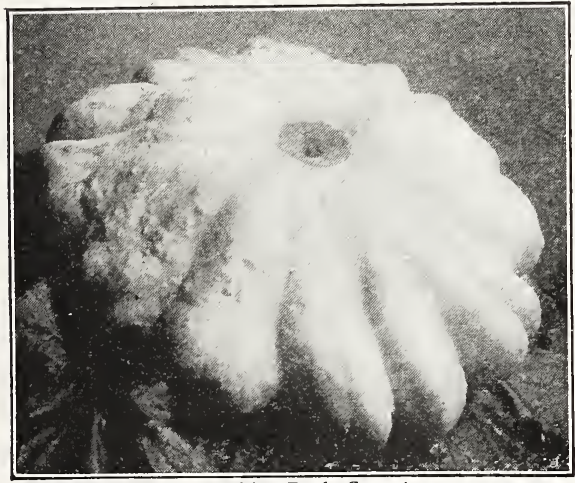

Early White Bush Squash

\section{YELLOW SUMMER CROOK NECK}

A Standard variety, early and productive. The squashes are about a foot long, with crooked neck and densely warted surface. Color, bright yellow; quality fine. Pkt., 10c; oz., 15c; 1/t lb., 40c; lb., \$1.25.

\section{GIANT YELLOW SUMMER CROOK NECK}

This variety is a very great improvement over the old variety in the enormous size and great beauty of its fruit; as their very attractive appearance commands the highest figure and prompt sales; it is of a beautiful golden color. Pkt., 10c; oz., 15c; 1/4 lb., 40c; lb., \$1.25.

\section{COCOZELLE, OR ITALIAN MARROW}

A very distinct variety, the skin smooth, of a dark green marbled with yellow, or pale green in stripes. The fruit is best when 6 to 8 inches long; very popular among the Italians. Pkt., 10c; oz., 15c; 1/4 lb., 50c; lb., $\$ 1.50$.

\section{ENGLISH VEGETABLE MARROW}

This is a very popular variety in England, and is gaining favor in this country. It pro. duces a succession of Squashes throughout the Summer, ranging in size from 9 to 18 inches long by 4 to 6 inches thick. Skin greenish yellow to a creamy white; flesh white and of a very rich flavor. We regard it as the best of all Summer varieties. Pkt., 10c; oz., 15c; $1 / 4$ lb., 50c; lb., \$1.50.
EARLY WHITE BUSH, OR PATTY.PAN

Earlier than any other variety; of dwarf habit and very productive; grows in a bush form, and occupies less room on the ground than any other sort; it is the variety that is grown the most extensively for market and shipping purposes. Summer Squashes should always be used when young and tender, which can be determined by an impression of the nail. Pkt., 10c; oz., 15c; 1/t 1b., 40c; lb., $\$ 1.25$.

GIANT SUMMER STRAIGHTNECK

A selection from the Giant Yellow Crook Neck, and is the same in all respects, except the neck, which is almost straight, and thus more easily packed for shipment. Pkt., 10c; oz., 20c; 1/t lb., 60c; lb., $\$ 2.00$.

\section{MAMMOTH WHITE BUSH}

This variety is a selection made from the Early White Bush; the improvement consists in the size of the Squashes it produces, which measure from 10 to 12 inches across; in every other respect it is identical with the old variety. Pkt., 10c; oz., 15c; 1/1 lb., 40c; lb., $\$ 1.25$.

\section{GOLDEN CUSTARD BUSH}

A valuable variety, which exceeds in size any of the scalloped sorts, frequently attaining a diameter of 1 foot. The color is a dark rich golden yellow. Pkt., 10c; oz., 15c; 1/4 lb., 40 c; lb., $\$ 1.25$.

\section{MAMMOTH YELLOW BUSH}

This is identical with the Mammoth White Bush, but the fruits are even larger and have a rich golden-orange skin. Pkt., 10c; oz., 15c; 1/4 lb., 40c; lb., \$1.25.

\section{EARLY YELLOW BUSH}

Exceeds in size any of the scalloped sorts, frequently 8 inches in diameter. A dark, rich, golden yellow. Quality excellent. It grows in bush form, wonder. fully productive. Pkt., 10c; oz., 15c; 1/́ lb., 40c; lb., \$1.25.

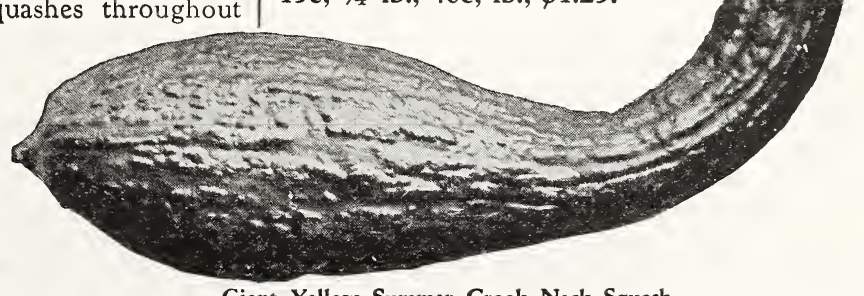

Giant Yellow Summer Crook Neck Squash 


\section{Varieties of Winter Squash}

BUIST'S IMPROVED MARROW

An improvement on the Boston Marrow, but similar to it in form; is more productive and of better flavor; for custards it cannot be surpassed, and keeps perfectly sound until late in Spring; wherever it has been introduced it becomes a general favorite. Pkt., 10c; oz., 15c; 1/4 lb., 40c; lb., \$1.25.

\section{CHICAGO WARTED HUBBARD}

This is a very fine strain of the famous Hubbard, having all the fine qualities of that popular Winter variety; is very roughly warted and of a darker green color; is a vigorous grower and of the very finest quality. Pkt., 10c; oz., 15c; 1/4 lb., 50c; lb., \$1.50.

\section{FORDHOOK}

Very desirable for either Summer or Win. ter use; the vines are vigorous, producing Squashes from 8 to 10 inches in length, of oblong form, slightly ridged, skin yellow and flesh of a lighter shade, quality unsurpassed. Pkt., 10c; oz., 15c; 1/4 lb., 40c; lb., \$1.25.

\section{BOSTON MARROW}

The favorite Winter Squash of the Eastern States. It is a very productive Fall and Winter variety, oval in shape, of fine flavor and a good keeper. The fruits when ripe are bright orange color. The flesh is of a rich salmon color, fine grained, firm, and the best for canning or pies. Pkt., 5c; oz., 10c; 1/4 lb., 30c; lb., \$1.00.

\section{MAMMOTH CHILI}

The largest of all Squashes, often attaining a weight of $150 \mathrm{lbs}$. Flesh thick, of a bright orange color, and keeps well. It is very productive, and will be found very profitable for stock feeding, while its rich, fine flavored flesh insures its value for all other purposes. Pkt., 10c; oz., 15c; 1/4 lb., 50c; lb., \$1.50.

\section{HUBBARD}

This is an old favorite and one of the best of the Winter Squashes. The vines are vigor. ous and very productive. The fruits are large, heravy and moderately warted, with a very hard shell. The flesh is light orangeyellow, fine grained, thick, dry and of superior flavor. It is an excellent keeper -and if stored properly, may bei used until Spring. Pkt., 10c; oz., 15c; 1/4 lb., 50c; lb., \$1.50.

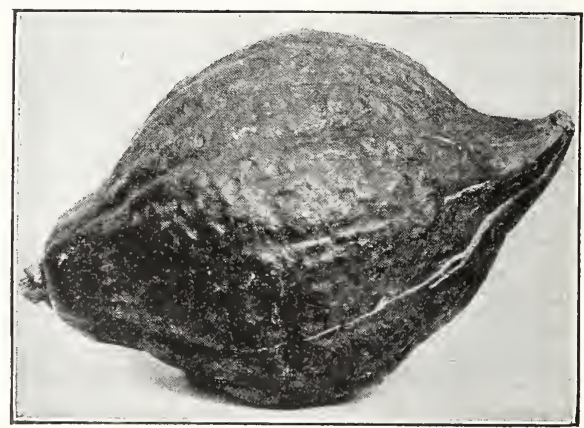

Hubbard Squash

\section{RED OR GOLDEN HUBBARD}

The heavily warted skin is of a rich orange. yellow, turning to deep salmon-red when ripened. The flesh is deep orange, dry, fine grained and richly flavored. It is very productive and fine in quality. Pkt., 10c; oz., $15 c$; $1 \frac{1}{4} \mathrm{lb} ., 50 \mathrm{c} ; \mathrm{lb} ., \$ 1.50$.

\section{THE DELICIOUS}

This variety, weighing from five to ten pounds, are delicious in flavor and splendid Winter keepers. The dark orange flesh is very thick and fine grained. Pkt., $10 \mathrm{c}$; oz., $15 \mathrm{c} ; 1 / 4$ lb., 50c; lb., \$1.50.

\section{Tomato}

TT IS a point of good gardening to have this vegetable early. To accomplish this, sow 1 early in spring in a mild hotbed and air freely in fine weather. When the young plants are three inches high, transplant them into another frame, to remain there until planted out; this will make them stronger and more stocky. For a late crop, sow the seeds in a very warm spot of the garden and cover them at night or during cold weather with boards. When the weather becomes mild and pleasant, transplant them in a sheltered part of the garden, facing south or southeast. As the plants advance, support them with a V trellis, which any one can make.

The earliest plants should have their tops pinched off as soon as they have set their fruit, which will cause them to ripen earlier.

Most cultivators allow their tomato vines to grow wild and support themselves; they, perhaps, have never given it a thought that by training and properly pruning them, they will not only increase their productiveness, but the fruit will ripen better and be of much finer quality.

Tomatoes that have not ripened at the end of the season may be taken from the vines and placed in empty coldframes, or wrapped in tissue paper, and carefully packed in flat boxes-where a large proportion of them will ripen from time to time, frequently until Christmas. 


\section{BUIST'S NEW MONARGH TOMATO}

\section{A Grand New Tomato}

Massive Size

Perfect Shape

Unequalled Solidity

The Highest Grade of Perfection

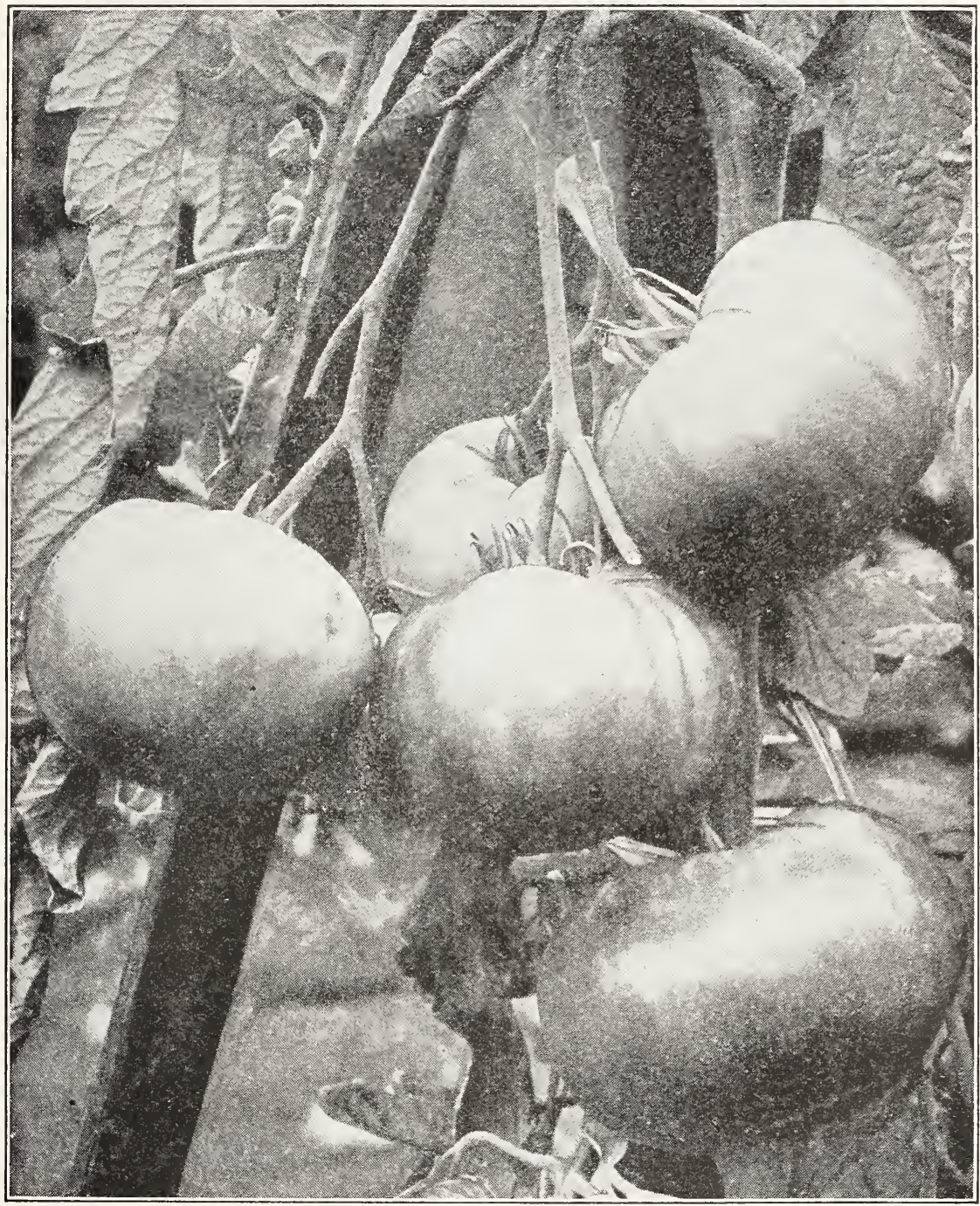

Buist's Monarch-We consider this the "King Pin" of all large, main crop Tomatoes possessing every point of merit to qualify as the perfect specimen.

Its mammoth fruit is of a rich glossy deep pink, of superior flavor, and the leading feature of this superb variety is, that it's perfectly smooth, ripening thoroughly to the stem, has but few seeds and is free from the hard core which is such an objectionable feature to many varieties; the vines are strong and vigorous; it's an immense yielder and continuous bearer, producing perfect specimens of two pounds and over and it holds its size to the end of the season, making it invaluable as an exhibition variety. (Note the immense size of illustration) also its solidity is unequaled by any other sort. To get the best results it should be grown on stakes or trellises.

We have received many complimentary letters, all designating it "The Monarch of all Tomatoes." Sold only in sealed packets. Pkt., 15c.; 4 Pkts., 50c. 


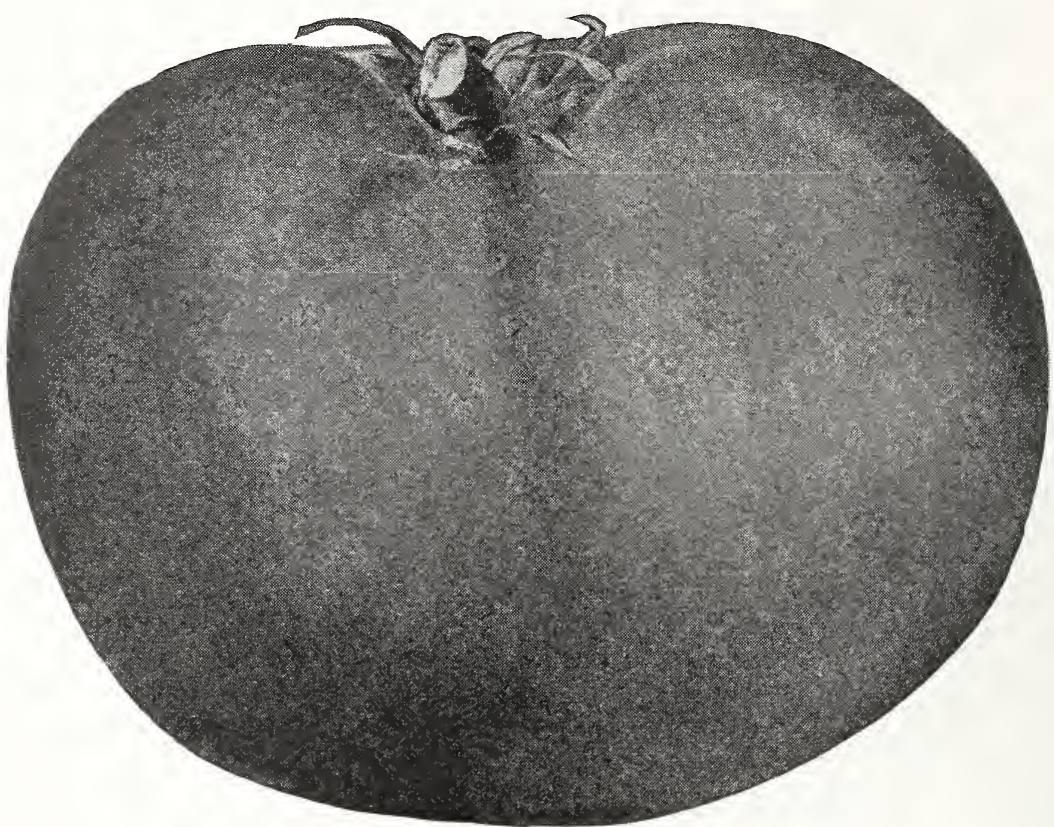

Buist's Scarlet Giant Tomato

Buist's Scarlet Giant Tomato-This new introduction is a scarlet sport of our famous Monarch, which it resembles in all respects except the color-a rich scarlet without any purple tint or shading. It is of immense size. A single tomato weighing two pounds is not unusual. The vines are vigorous and not subject to blight or rust. It has very few seeds, no core, and ripens evenly to the stem. For best results, train a single stem on stakes or trellisses. Pkt., 15c.; I/4 oz., 35c.; I/2 oz., 60c.; oz., \$1.00; I/4 lb., $\$ 3.50$.

Buist's "Earli-Belle"-The "Early Money" variety for market gardeners. A tomato with all the good qualities of our famous Prize Belle as regards smoothness, uniformity in size, shape, solidity and flavor, but ripening three weeks earlier. It is without question the best and most profitable early variety to grow for market or private garden. The fruit, of a rich scarlet color, grows to a large size; very prolific; smooth and uniform. This variety can also be grown under glass. Pkt., 10c.; I/2 oz., 20c.; Oz., 35c; $1 / 4$ lb., $\$ 1.15$; lb., $\$ 4.00$.

Buist's Prize Belle-This variety was introduced by us after years of selection, and is unrivaled for the home garden and canning purposes; it is also unsurpassed as a market variety, being quite early and of a large size; fruit of a rich cardinal red, solid as an apple, almost seedless; a strong, vigorous grower. The tomatoes are always of a large size. Pkt., 10c.; I/2 Oz., 20c.; oz., 40c.; $1 / 4$ lb., $\$ 1.25 ; 1$ b., $\$ 4.50$.
Buist's Selected Prize Stone-The Stone is a great favorite with all cultivators of the Tomato, and this selected strain we offer is the result of an annual selection for several seasons, making it a great improvement in the solidity, productiveness, form and richness of color, and is without question the finest stock obtainable. The vines are large, vigorous and very productive, the fruit is of a bright deep scarlet color, exceptionally smooth, ripening evenly to the stem without a crack. Its solidity and carrying qualities are remarkable; it is a good keeper, free from core and not subject to rot. Highly recommended for a main crop. Pkt., 10c.; $1 / 2$ oz., 20c.; oz., 35c.; 1/4 lb., \$1.10; lb., \$3.75.

The Brimmer-A splendid variety for the home garden. The fruits are very large, thick meated, solid and of delicious flavor. The Brimmer bears a prolific crop of perfectly shaped tomatoes that ripen clear to the stem, holding their size to end of season. There is no core, very few seeds, and the flesh is like a beefsteak. Pkt., 10c.; I/2 oz., 30c.; oz., 50c.; $1 / 4$ lb., $\$ 2.00 ; 1 b ., \$ 7.00$.

Greater Baltimore-A main crop variety, excellent for canning, producing a large, solid, smooth fruit of a brilliant red color of excellent quality. The plant is a strong, thrifty grower, bearing with undiminished vigor until frost. Superior to other main-crop Tomatoes for its heavy yield and high quality. Pkt., 10c.; $1 / 2$ oz., 15c.; oz., 30c.; 1/4 lb., 90c.; lb., $\$ 3.00$. 


\section{BUIST'S SELECTED GLOBE}

\section{Immensely Productive, Blight Proof} Perfectly Globe-Shaped

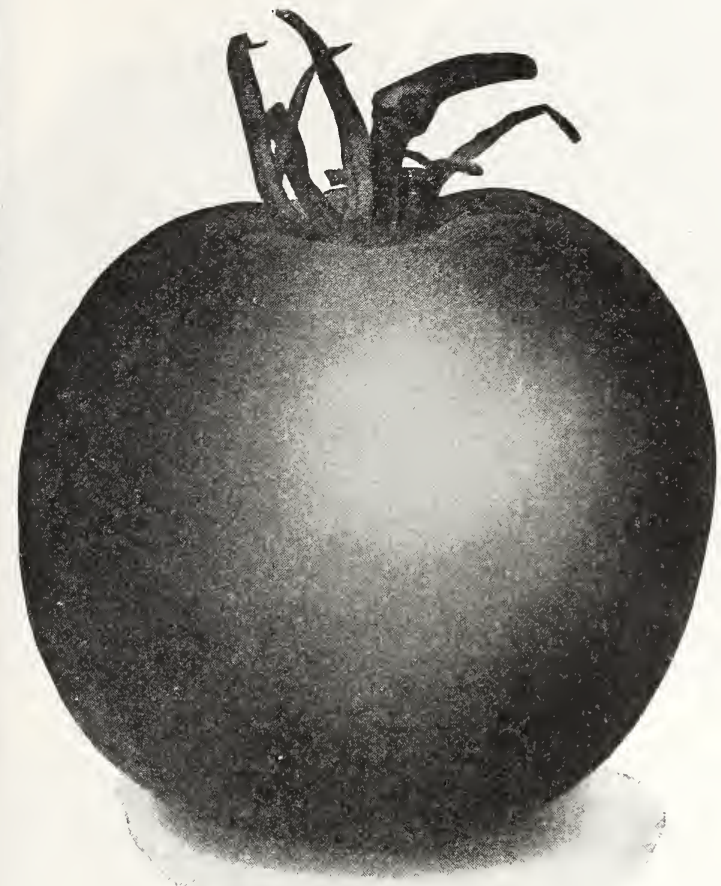

Buist's Selected New Globe Tomato

\section{Buist's Selected Globe}

There is a constantly increasing demand for this magnificent shipping variety from the largest growers and shippers of Florida and Texas. The fruit is much larger than Livingston Globe, very firm flesh and stands transportation well; they can be picked green to reach the Northern markets in good condition. Vines very vigorous, the plants having many short joints at which large clusters form invariably bearing three to seven fine, handsome tomatoes; color rich glossy deep pink, ripening to the stem; flavor superb, free from core, so general in other sorts. Highly recommended to growers and shippers. Excellent for canning. Pkt., 10c.; I/2 oz., 25c.; oz., 45c.; I/4 lb., $\$ 1.50$; 1b., $\$ 5.00$.

Improved New Stone-One of the most popular varieties and highly recommended for both canning purposes and private gardens. Fruit very large and smooth; color bright scarlet, ripening evenly to the stem without a crack; exceedingly solid and firm-fleshed, of the finest quality. The plants grow vigorously and are very productive Pkt., 10c.; I/2 oz., 15c.; oz., 30c.; I/4 lb., 90c.; lb., $\$ 3.00$.
Marglobe-A main crop scarlet-fruited variety introduced by the U. S. Dept. of Agriculture for wilt resistance and claimed to be also resistant to "nail-head rust." The fruits are medium size, smooth, red and globular in shape. It is as early as the Bonnie Best and continues to bear for a longer period. Large yields have been reported from nearly every section where this variety has been grown. Pkt., 10c.; I $/ 2$ oz., 25c.; oz., 50c.; I/4 lb., $\$ 1.75$; lb., \$6.00.

Coopers Special-A vigorous, productive, second early variety. Fruits of medium size, globe-shaped, smooth and solid; color purplish pink. Its many fine qualities make it very desirable for the market gardener and shipper. Pkt., 10c.; I/2 Oz., 25c.; oz., 40c.; 2/4 lb., \$1.25; lb., $\$ 4.50$.

The Matchless-This is a very desirable variety to grow for main crop, producing bright red and solid fruit, of large size and beautiful form, perfectly smooth, and has very few seeds. Very popular with all tomato growers. Pkt., 10c.; $1 / 2$ oz., 15c; oz., 30c.; I/4 lb., $\$ 1.00$; 1b., $\$ 3.50$.
Livingston's Globe-A popular variety in Florida, a good shipper. In shape this Tomato is distinct from all others, being a beautiful globe. It is of large size, always smooth, firm-fleshed, very few seeds, especially in the early fruits; ripens evenly through and through, a fine glossy rose in color, tinged with purple; very productive. Pkt., 10c.; I/2 oz., 20c.; oz., 40c.; I/4 lb., \$1.25; lb., $\$ 4.50$.

Florida Special-A variety of recent introduction, which is claimed to be blight proof. The crop ripens very uniformly, vines vigorous. The fruits are medium sized, bright scarlet, exceedingly smooth, solid, and of very good quality. Pkt., 10c.; $1 / 2$ oz., $15 \mathrm{c}$.; oz., 30 c.; $1 / 4$ lb., $\$ 1.00$; 1b., $\$ 3.50$.

Norton Wilt Resistant-A main crop scarlet-fruited variety developed from the Stone. The fruits are bright scarlet, oval and very deep, exceptionally smooth and uniform in size. One of the best long-distance shippers. Pkt., 10c.; $1 / 2$ Oz., 15c.; Oz., 30c.; 1/4 1b., $\$ 1.00$; 1b., $\$ 3.50$. 


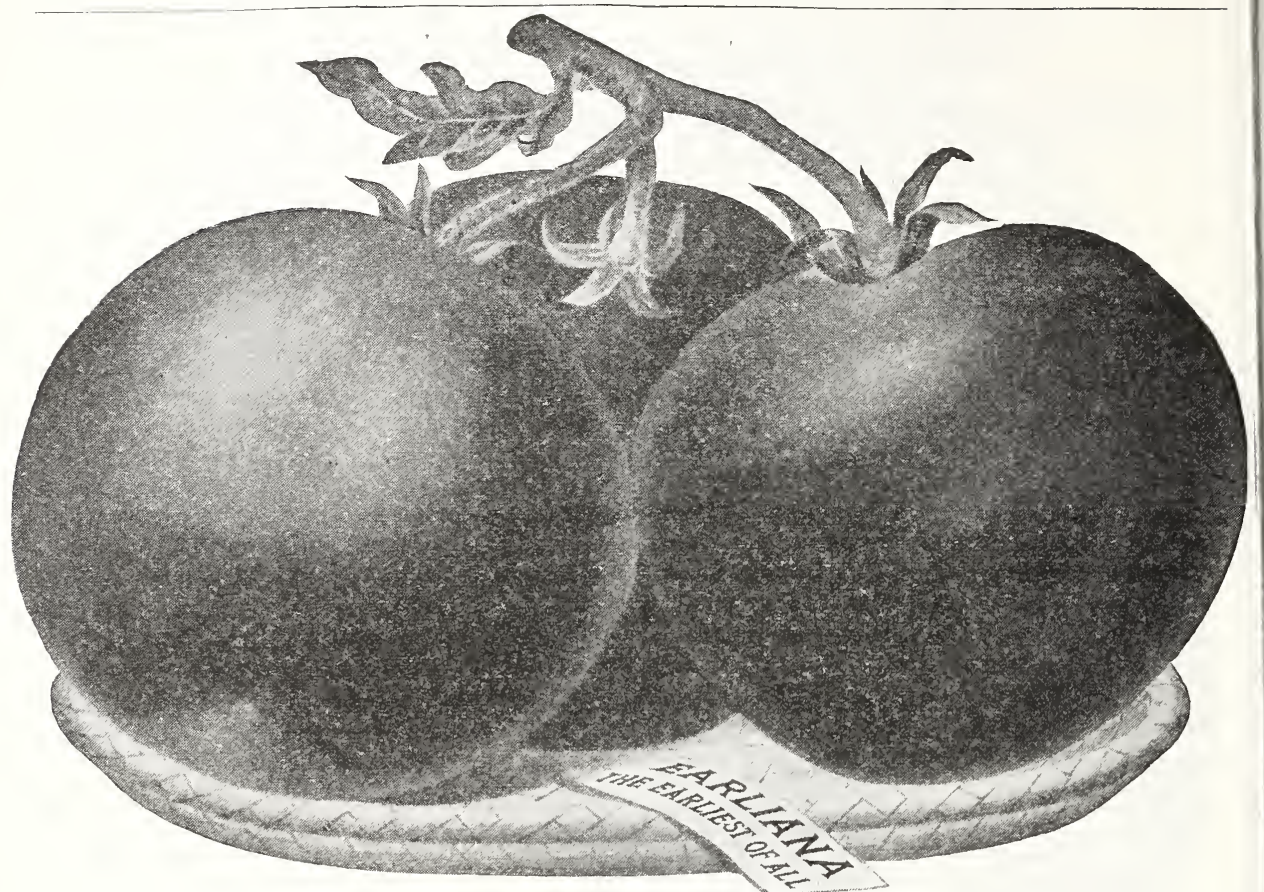

\section{SPARKS' EARLIANA}

This is the earliest red tomato known. The fruit is of a deep scarlet color, which is pro. duced in clusters of five to eight, averaging two and a half inches in diameter and quite solid; it is a valuable and most profitable variety to grow for early market, as the profit in tomato culture is always in the earliness of the crop. Pkt., 10c; 1/2 oz., 15c; oz., 30c; $1 / 4$ lb., $\$ 1.00 ; \mathrm{lb} ., \$ 3.50$.

\section{BONNIE BEST}

A very beautiful early variety, following the Earliana in ripening. The vines are vigorous and produce a good crop of round and deep fruits, bright scarlet in color and of very good quality; is suitable for both an early and main crop. A very good variety for the early market and home gardens. Pkt., 10c; $1 / 2$ oz., 15c; oz., 30c; 1/4 lb., \$1.00; lb., $\$ 3.50$.

\section{CHALK'S EARLY JEWEL}

This famous early variety originated with a market gardener near Norristown, $\mathrm{Pa}$., who is noted for the fine selection of almost every crop he grows; it is a remarkable variety which follows the Earliana in ripening, more solid and of fine form. Color bright scarlet, and a very desirable variety for either market or private garden. Pkt., 10c; 1/2 oz., 15c; oz., 30c; 1/4 lb., \$1.00; lb., \$3.50.

\section{EARLY DETROIT}

A very large pink tomato, vines vigorous and very productive, fruit smooth, uniform in size, nearly globe shaped, firm and of excellent quality; a good shipper. Pkt., 10c; 1/2 oz., 20c; oz., 35c; 1/4 lb., \$1.15; lb., \$4.00.

\section{BUIST'S MARKET CHAMPION}

This magnificent new main crop tomato possesses all the good qualities to make it the ideal tomato for market and the home garden. The vines are large, hardy and productive. The fruits are bright scarlet, oval and deep, exceptionally smooth, ripening evenly to the stem without cracking. This new introduc, tion of ours is the best of all tomatoes for canning and is unsurpassed as a money-maker for the market gardener. Pkt., 1.0c; 1/2 oz., $25 \mathrm{c}$; oz., 50c; 1/4 lb., \$1.75; lb., \$6.00.

\section{JOHN BAER}

A new early variety of recent introduction. The plants are of vigorous growth, very productive, ripening evenly to the stem; about ten days later than Earliana; retaining its size to end of season. Fruit is a bright red and very attractive. A good sort for market gar. deners. Pkt., 10c; 1'́2 oz., 15c; oz., 30c; 1/4 lb., \$1.00; lb., \$3.50.

\section{RED ROCK}

A main crop variety; similar in character to the Stone. Very productive and a good shipper. Fruit is a briliant red, exceptoinally smooth and uniform in size; flesh, very firm; and is excellent for canning. Pkt., 10c; 1/2 oz., $15 \mathrm{c}$; oz., 30c; 1/4 1b., 90c; lb., \$3.00.

\section{DWARF STONE}

A very remarkable dwarf variety. Stronger in growth and more erect than the Dwarf Champion, and fruit equal to the regular Stone in form, solidity and color; of fine flavor and highly recommended as a dwarf variety. Pkt., 10c; 1/2 oz., 20c; oz., 40c; 1/4 lb., $\$ 1.25$; lb., $\$ 4.50$. 


\section{JUNE PINK}

This is the earliest of the pink varieties and is similar in habit to the famous Earliana, resem. bling that variety in every way except the color. Produces its fruit in clusters; ripens early, of fair size and continues bearing until frost. In markets where pink tomatoes are preferred, they will com. mand a much higher price than any of the various red varieties. Pkt., 10c; 1/2 oz., 20c; oz., 40c; 1/4 lb., $\$ 1.25$; lb., $\$ 4.50$.

\section{HENDERSON'S}

PONDEROSA

A monster in size. The fruit is oblong, solid and of good flavor; color a purplish pink. Ripens at midseason and continues to bear until frost. It is a grand exhibition variety. Pkt., 10c; 1/2 oz., 25c; oz., 50c; 1/4 lb., \$1.75; lb., \$6.00.

\section{LIVINGSTON'S BEAUTY}

This variety is exceedingly popular and very attractive in appearance, and ripens with the Acme; of a rich, glossy, crimson color, with a slight tinge of purple; of handsome form, solid, and stands transportation. Pkt., 10c; 1/2 oz., 15c; oz., 30c; $1 / 4$ lb., $\$ 1.00 ; 1 b$. $\$ 3.50$.

\section{NEW DWARF PONDEROSA}

The largest of all dwarf tomatoes. The fruit, gigantic in size, has the mild, sweet flavor of the Ponderosa. Color a deep purplish crimson. Vines are strong and vigorous, of upright growth, requiring no sup. port. Pkt., 10c; 1/2 oz., 25c; oz., 50c; 1/4 lb., $\$ 1.75$; lb., $\$ 6.00$.

\section{ACME}

This celebrated variety is of an entirely dis. tinct character, and is very popular. It is well adapted for Southern culture; form round, slightly depressed at the ends, very smooth; color a glossy dark red with a sort of purplish tinge. Pkt., 10c; 1/2 oz., 15c; oz., 30c; $1 / 4$ lb., \$1.00; lb., \$3.50.

\section{DWARF CHAMPION}

A distinct and valuable variety; dwarf, stiff habit, scarcely requiring any support; it is very early and wonderfully prolific; color same as Acme. Is perfectly round and smooth, of medium size. Pkt., 10c; 1/2 oz., 20c; oz., 40c; $1 / 4$ lb., \$1.25; lb., \$4.50.

\section{CRIMSON CUSHION OR BEEFSTEAK}

A scarlet sport of the Ponderosa, but the color is brilliant crimson. Flesh solid, of best quality. Pkt., 10c; 1/2 oz., 25c; oz., 45c; 1/4 lb., \$1.50; lb., \$5.00.
Buist's Market Champion Tomato

\section{GLLF STATE MARKET}

A popular tomato with gardeners who ship to distant markets. The vines are vigorous and withstand blight exceptionally well. The fruits are round, or globe shaped, smooth, free from cracks. Color deep purplish pink, ripening well about the stem. Pkt., 10c; 1/2 oz., 20c; oz., 40c; 1/4 lb., \$1.25; lb., \$4.50.

\section{REDFIELD BEAUTY}

A popular variety in Florida, a good ship. per, very regular in size and shape, color glossy crimson with a slight tinge of purple. Pkt., 10c; oz., 30c; $1 / 4$ lb., $\$ 1.00 ; 1$ lb., $\$ 3.50$.

\section{GOLDEN PONDEROSA}

Equals the red Ponderosa in size, the color is a deep golden yellow. Pkt., 10c; 1/2 oz., 30c; oz., 50c; 1/4 lb., \$1.75.

\section{GOLDEN QUEEN}

The fruits are large and smooth; of a beautiful light yellow, occasionally streaked with red. A desirable variety for preserving as well as for the table. Pkt., 10c; 1/2 oz., 20c; oz., 40c; $1 / 4$ lb., $\$ 1.25 ;$ lb., $\$ 4.50$.

\section{COMET}

Rich scarlet, medium size, used almost ex. clusively for forcing. Pkt., 10c; 1/2 oz., 30c; oz., 50c; 1/4 lb., \$1.75.

\section{YELLOW PLUM}

Shape uniformly oval and perfectly smooth; color lemon yellow; used for preserving and pickling. Pkt., 10c; 1/2 oz., 30c; oz., 55c; 1/4 lb., $\$ 1.90$.

\section{RED PEAR OR PLUM SHAPED}

Produce their fruit in clusters; desirable for preserving or pickling purposes. Pkt., 10c; 1/2 oz., 30c; oz., 55c; 1/4 lb., \$1.90. 


\section{TURNIP}

THE cultivation of the Turnip in this country is greatly on the increase; and especially in the South it is always a very desirable and profitable crop to grow; is of the easiest culture, but requires good, deep, rich soil and should be sown before or after a rain, while the ground is moist, as the success of the crop will depend in a great measure on the strength of the early growth. The fly is very destructive to the Turnip crop, especially during warm, dry weather, and frequently they will eat off an entire field as fast as the young plants make their appearance. The best plan is to sow an abundance of seed, at the rate of two pounds to the acre, and if the plants are too thick in the drills, thin them out by hoeing, or with a light harrow if sown broadcast. As soon as the plants form their rough leaves, they are safe from the attacks of the fly; but should the crop be destroyed, loosen or harrow the ground immediately and resow at once. A dusting of plaster on the plants as they appear will frequently prevent such attacks. For an early Summer crop, sow very early in Spring the Early White Flat Dutch, or Red Top Flat and Buist's Purple Top Globe, in good, rich soil, either broadcast or in drills $1 \frac{1}{2}$ to 2 feet apart; when the plants are up, thin them out to about 4 inches apart. For a general Fall crop, sow late in Summer or early Autumn the flat strap-leaved varieties broadcast, and the large, round varieties in drills. If you have never grown Buist's Mammoth Purple Top Globe, try it; it is the variety of the future; it can be sown either broadcast or in drills. Ruta Baga, or Swede should be sown in July, and always in drills 20 inches apart, and then the plants thinned out to stand 6 inches, as the plants grow ridge up to them, otherwise they will form no bulbs. A seed sower should always be used for sowing Turnip seeds in drills. Select the Planet Jr. Drill, as it is the best.

\section{WINTERING TURNIPS}

Turnips may be kept perfectly sound until Spring by being taken up about the 1 st of November or before severe frost sets in. Cut the leaves off to about $1 / 2$ inch of the bulb; collect the latter and put them in a dry pit or cellar; cover with straw and earth over all. Thus protected, they will be found fresh and perfect until February; the Swede will be fit for the table about April. Those for Spring use can be pitted out of doors in a dry situation without topping the foliage, piling them in a conical form, and covering them with 3 inches of straw and a foot or 18 inches of earth, which will be ample protection. When opened in Spring, these wili be found to have nearly all the flavor of being fresh from the field.

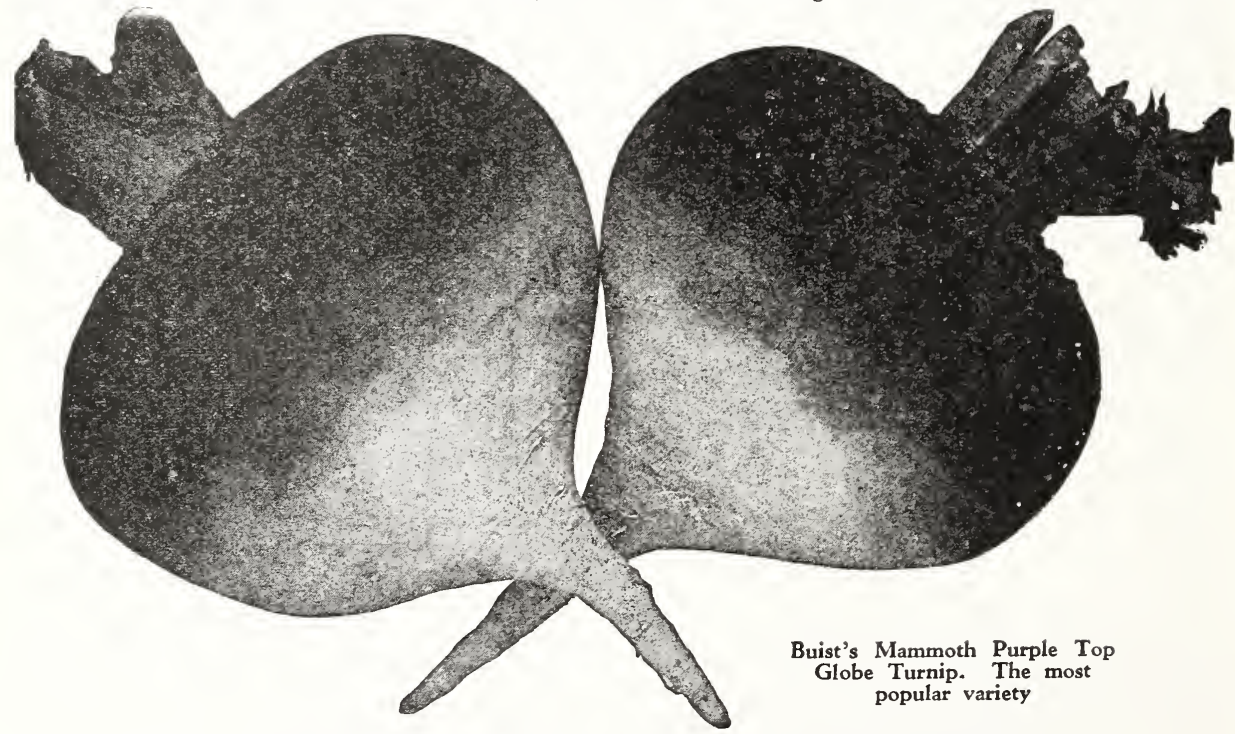

\section{BUIST'S MAMMOTH PURPLE TOP WHITE GLOBE}

This is one of the most valuable, most popular and most salable varieties now grown; it is of globe shape, flesh pure white, with a red or purple top, and of very rapid growth; it is of the same character and habit as the Red or Purple Top Flat, differing only in its form and leaves; but owing to the great size and thickness of the root, it will produce twice as much to the acre; it is also a good Winter variety; it can be sown either broadcast or in drills, and is always a sure cropper. We annually grow over 100 acres to supply the demand of our customers. Pkt., 5c; oz., 10c; 14 lb., 25c; 1b., 75c. 


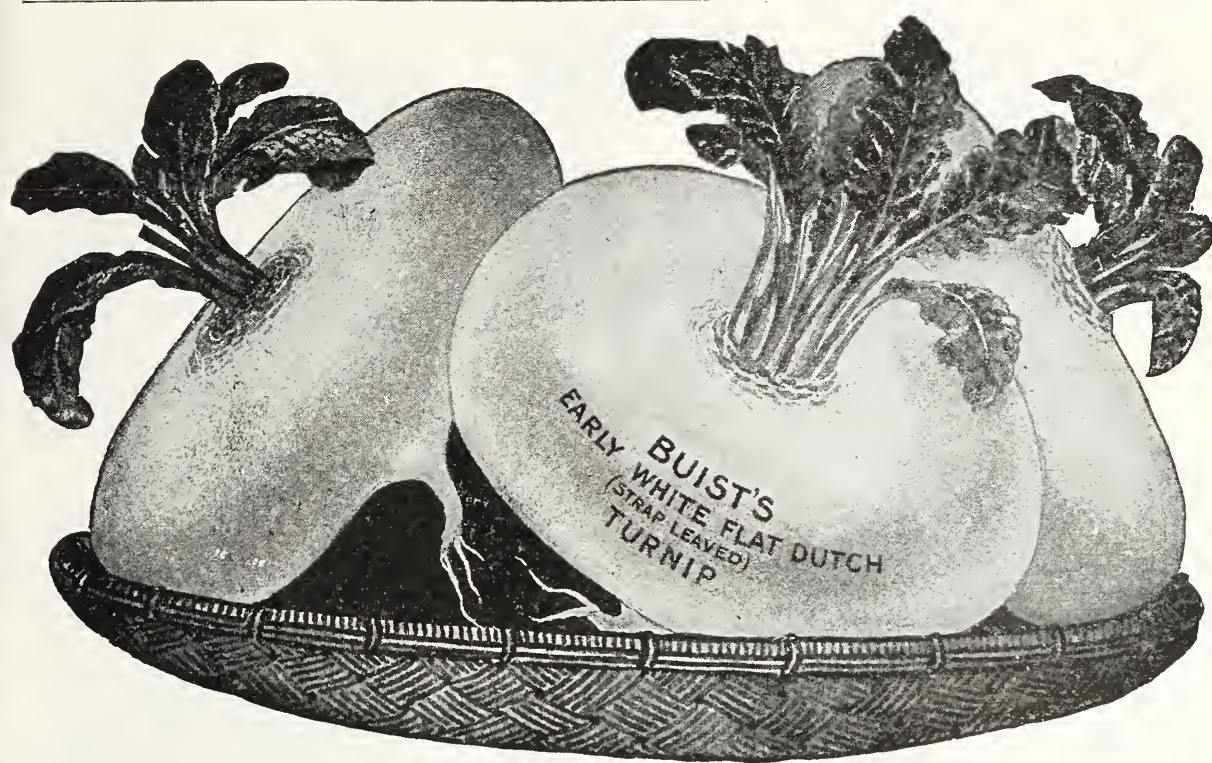

Early White Flat Dutch Turnip

RED OR PURPLE TOP FLAT

A variety of the easiest culture, and a general favorite with all; will do well sown either broadcast or in drills, and will form good. sized bulbs in a favorable season in about seven or eight weeks from sowing; it is of a perfectly flat form with a small tap-root and a bright purple top; the leaves are short and narrow, it is a fine table variety and excellent for feeding stock. Pkt., 5c; oz., 10c; 1/4 lb., 20c; lb., 65c.

\section{LARGE PURPLE TOP WHITE GLOBE}

This variety is of the same habit, color and form as Buist's Mammoth, but the roots it produces are very much smaller in size; it was from this variety that the Mammoth originated by the careful selection of the largest and finest roots. Pkt., 5c; oz., 10c; 1/4 lb., 20c; lb., 65 c.

\section{LONG WHITE COW-HORN}

A pure white variety with green top, grow, ing in shape similar to a cow's horn; is desirable for both table use and for stock feeding. The flesh is fine grained and well flavored. Pkt., 5c; oz., 10c; 1/4 lb., 25c; lb., 75c.

\section{POMERANEAN WHITE GLOBE}

This is a very handsome and popular variety, selected from the White Globe, from which it differs only in the size and beauty of its roots. It is especially adapted to the Southern States. Pkt., 5c; oz., 10c; 1/4 lb., 20c; lb., 65c.

\section{LARGE WHITE NORFOLK}

This variety produces large white globeshaped roots, excellent for table or stock. The tops are extensively used for greens. Pkt., 5c; oz., 10c; 1/4 lb., 20c; lb., 65c.

\section{EARLY WHITE FLAT DUTCH}

This is one of the earliest varieties, and can be sown either broadcast or in drills; it is without exception the best and most popular early sort for either table use or for market; is of a beautiful flat form, of pure white color and of a delicate, mild flavor. It produces bulbs entirely free from small roots and with long, narrow strap leaves growing erect, which permits close culture. Pkt., 5c; oz., 10c; 1/4 lb., 20c; lb., 65c.

\section{LARGE WHITE GLOBE}

A variety grown extensively for stock feed. ing; should be used in the Fall or early Winter, as it becomes pithy before Spring. It is of a globe shape; flesh and skin white. Pkt., 5c; oz., 10c; 1/4 lb., 25c; lb., 65c.

\section{EARLY SNOW-WHITE GLOBE}

This is one of the most beautifully formed varieties known; of pure snow-white color, and almost as round as a ball; a very desirable and productive early market variety; is far superior to the White Globe for a general crop. Pkt., 5c; oz., 10c; 1/1 1b., 25c; lb., 75c.

\section{EARLY WHITE EGG}

A very popular and desirable early variety; pure white; of egg shape. The flesh is sweet, firm and mild. Pkt., 5c; oz., 10c; 1/4 lb., 25c; lb., 75c.

\section{EXTRA EARLY PURPLE TOP MILAN}

This celebrated foreign variety is the earliest strap-leaved turnip in cultivation; flesh pure white, purple top, of flat form and ex. cellent quality. Highly recommended for an early crop. Pkt., 5c; oz., 10c; 1/4 lb., 30c; lb., \$1.00. 


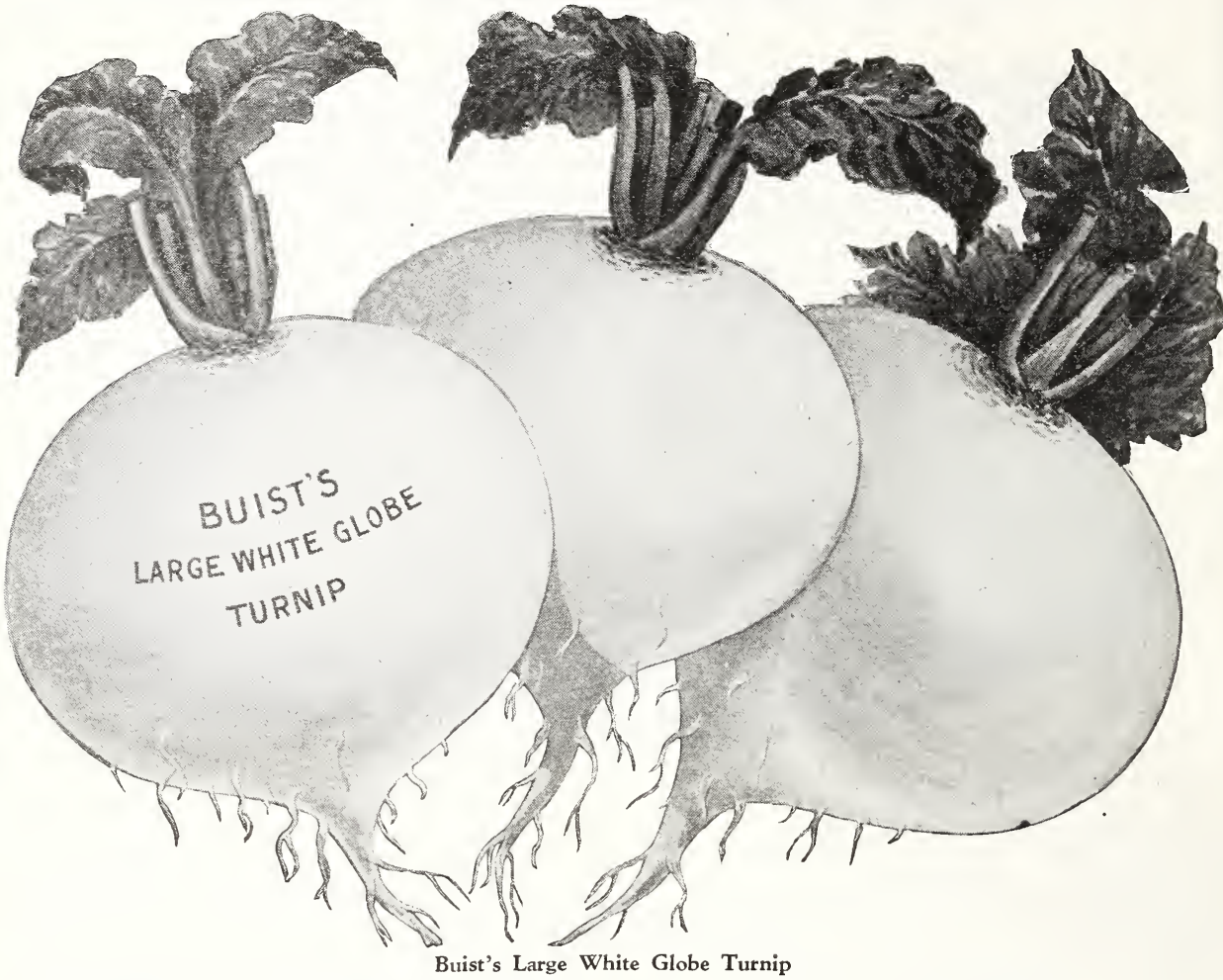

PURPLE TOP YELLOW ABERDEEN

This is one of the most popular foreign varieties, but cultivated to a very limited extent in this country. It resembles a very handsomely formed Ruta Baga, and for feed. ing purposes is fully equal to them and keeps solid until very late in the season. It can be sown with success fully a month later than the Swede, and is also quite desirable for table use. Pkt., 5c; oz., 10c; 1/4 lb., 20c; 1b., 65c.

\section{AMBER GLOBE}

This is a very beautifully formed variety, of an amber color, quite productive, solid flesh, and attractive in appearance; it keeps well and is desirable for either table use or stock feeding. Pkt., 5c; oz., 10c; 1/4 lb., 20c; lb., 65c.

\section{GOLDEN BALL}

The best of the Yellows for a Fall crop; is very solid and of good flavor; flesh bright orange, of a globe form; an excellent table variety. Pkt., 5c; oz., 10c; 1/4 lb., 20c; lb., 65c.

\section{EXTRA EARLY WHITE MILAN}

This is the earliest of all varieties; of a perfect flat form; pure white; small foliage and of fine quality; as an early market variety it is unsurpassed. Pkt., 5c; oz., 15c; 1/4 lb., 35c; lb., $\$ 1.00$.
EARLY SNOWBALL

A small white globe variety, very handsome, extra early, tender and sweet; highly recommended. Pkt., 5c; oz., 10c; 1/4 lb., 25c; lb., $75 \mathrm{c}$.

\section{LARGE YELLOW GLOBE}

This is very similar to the Golden Ball; flesh pale yellow, very solid and keeps well; grows to a medium size and is an excellent table variety. Pkt., 5c; oz., 10c; 1/4 lb., 20c; lb., 65c.

\section{SOUTHERN SEVEN TOP}

This, the hardiest of all sorts, may be left standing in the open ground during Winter as far North as Philadelphia. In the Southern States it yields in the Spring abundant foliage for boiling with cured meats. It forms no turnips. Pkt., 5c; oz., 10c; 1/4 lb., 20c; lb., 60c.

\section{SOUTHERN PRIZE}

This variety is used only in the South for Winter greens; it is very hardy and stands the Winter without protection; highly recom. mended. Pkt., 5c; oz., 10c; 1/4 lb., 20c; 1b.,60c.

\section{MAMMOTH SHOGOIN}

An excellent Japanese table variety grow. ing to a large size without impairing the sweetness of its flavor. The tops are very abundant and highly recommended as a salad variety. Pkt., 10c; oz., 15c; 1/4 lb., 40c; lb., $\$ 1.25$.

Buist's Turnip Seeds produce the largest and finest formed roots 


\section{RUTA BAGA, OR SWEDISH TURNIP}

7 HE cultivation of the Ruta Baga is greatly on the increase in this country, but we are still very much behind Great Britain, where fully one-fifth of the agricultural districts are cultivated in this crop for Winter food for both cattle and sheep; in many sections of our country its cultivation is not thoroughly understood, as we have observed, especially in the South, that it is frequently sown broadcast; the result is that the crop proves a failure, as it will rarely, if ever, form bulbs when sown in this manner; it should always be sown on raised ridges, which should be slightly leveled off with the back of a harrow and lightly rolled after seeding, and as the plants grow, ridge up to them, which causes them to form their bulbs. If this is not done, no crop can be produced.

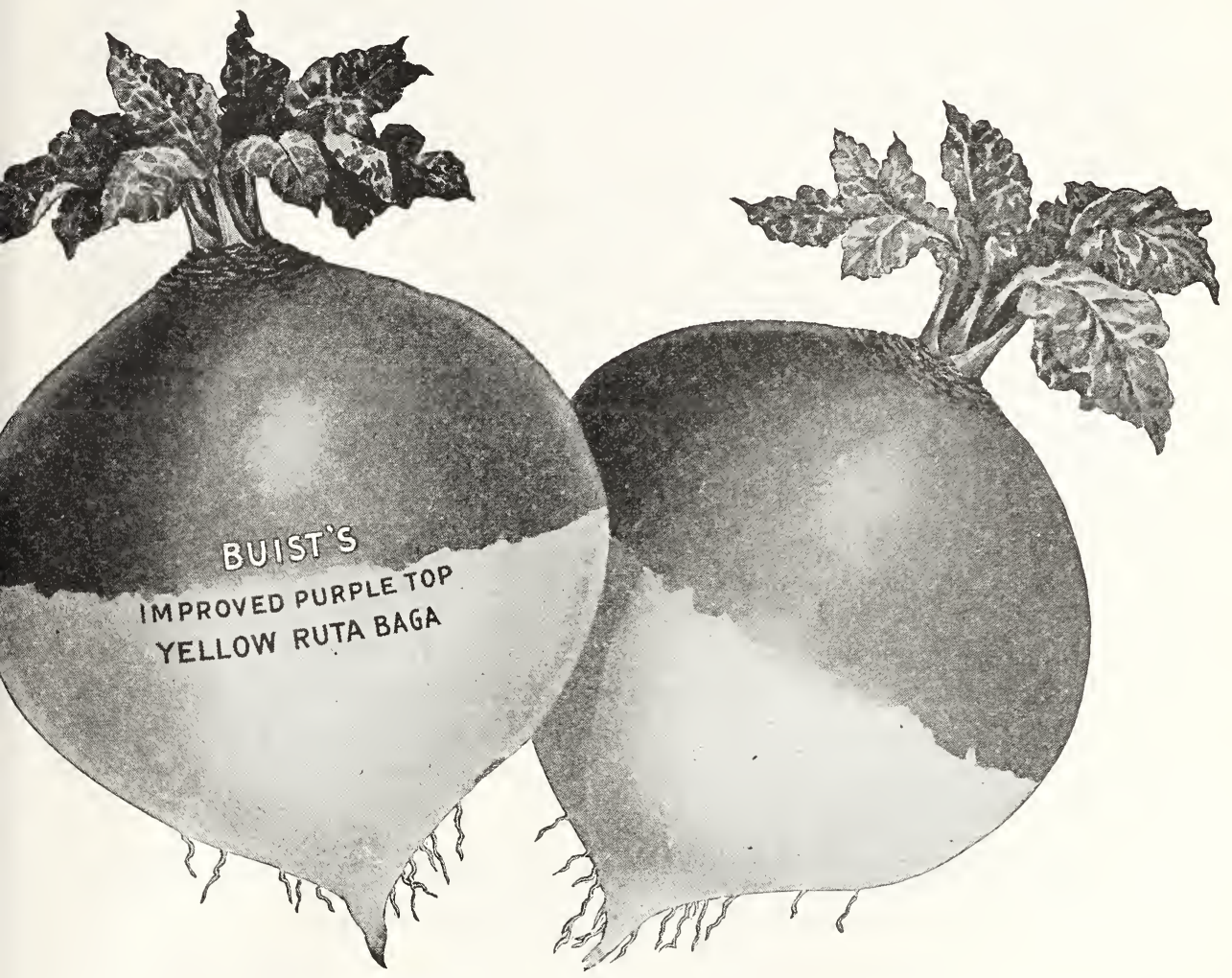

Buist's Improved Yellow Ruta Baga

\section{BUIST'S IMPROVED PURPLE TOP YELLOW RUTA BAGA}

This is the largest and most productive Ruta Baga known; there is no variety which has gained a greater reputation throughout the entire country than Buist's Improved. Testi, monials are continually being received by us endorsing its fine qualities and productive, ness; it cannot be too highly recommended, and no sort will produce such handsomely formed roots or greater yield; it has an ex. ceedingly short neck, is very solid, of a beauti. ful orange or amber color, with a handsome purple top, and is the result of many years of careful selection. Pkt., 5c; oz., 10c; 1/4 lb., $25 \mathrm{c}$; lb., $75 \mathrm{c}$.
CANADIAN GEM

A favorite variety of Ruta Baga with the Canadian growers, of uniform growth and fine quality, and can be depended on to give satis. faction. Roots are nearly round, purple above ground, yellow beneath, small tops and short neck, flesh yellow. It is a quick grower, hardy and resists mildew. Pkt., 5c; oz., 10c; 1/4 lb., lb., 30c; 1b., 90c.

\section{LONG ISLAND SWEDE}

Originated on Long Island and grown very extensively in this section; is of a very hand. some form, of an amber color with a purple top, but produces smaller roots than most varieties of this class. Pkt., 5c; oz., 10c; $1 / 4$ lb., 25c; lb., \$75c. 


\section{BREADSTONE}

This variety, although frequently called a turnip, should be classed as a Ruta Baga; it produces roots of good size, of oval form, skin and flesh pure white, and of very finest quality for table use; it keeps well throughout the Winter. Pkt., 5c; oz., 10c; 14 lb., 25c; lb., 75 c.

\section{DANISH BANGHOLM SWEDE}

A particularly fine type of Ruta Baga both in shape and quality. The roots are of large size, slightly tankard shape, with short necks. The skin is yellow, with purple top. The flesh is yellow, firm, solid, and of mild flavor. It is a hardy variety and yields heavily. An excellent sort either for the table or stock feeding. Pkt., 5c; oz., 10c; 1/4 lb., 25c; lb., $75 \mathrm{c}$.

\section{GOLDEN NECKLESS}

Flesh creamy yellow, fine grained and of ex. cellent quality and particularly desirable for table use. Very small neck. Pkt., 5c; oz., 10c; 1/4 lb., 25c; lb., 75c.

\section{SWEET GERMAN}

Flesh white, hard and firm, partaking much of the nature of a Ruta Baga. Must be sown much earlier than the flat varieties. In the Autumn and early Winter it is apt to be hard, but mellows like an apple. Pkt., 5c; oz., 10c; 1/4 lb., 25c; lb., 75c.

\section{LARGE WHITE OR WHITE RUSSIAN}

A pure white variety, of irregular shape, of large size, and a solid keeper; flesh very sweet. Pkt., 5c; oz., 10c; 1/4 lb., 25c; lb., 75c.

\section{Tobacco}

\section{CULTURE}

Sow seed for plants early in Spring in frames or seed-bed, using soil well enriched with wood-ashes. When weather becomes warm, transplant to open ground in rows 4 feet apart and cultivate frequently. One ounce will produce 5000 plants-sufficient for an acre.

\section{CONNECTICUT SEED LEAF}

The most popular sort for cigar wrappers. Pkt., 10c; oz., 50c; 1/4 lb., \$1.50.

\section{BIG ORONOKO}

A very large and heavy variety for fillers and dark wrappers. Pkt., 10c; oz., 35c; 1/4 lb., $\$ 1.10$.

\section{HESTER IMPROVED}

Yellow, fine for cigars. Pkt., 10c; oz., 40c; $1 / 4$ lb., $\$ 1.25$.

\section{SWEET ORONOKO}

Considered the best natural chewing leaf. Pkt., 10c; oz., 35c; 1/4 lb., \$1.10.

\section{YELLOW ORONOKO}

A reliable yellow variety, used for wrap. pers, also cigarettes. Pkt., 10c; oz., 40c; 1/4 lb., $\$ 1.25$.

\section{BLUE PRYOR}

The genuine James River favorite. Pkt., 10c; oz., 50c; 1/4 lb., \$1.50.

WARNE

A splendid variety for light yellow wrap. pers, leaf large, tough and silky. Pkt., 10c; oz., 40c; 1/4 lb., \$1.25.

\section{BIG HAVANA}

An Americanized Havana, used for cigar purposes. A heavy cropper and the earliest to mature. Pkt., 10c; oz., 40c; 1/4 lb., \$1.25.

\section{IMPROVED LONG LEAF GOOCH}

An ideal variety for sandy soils; produces large, broad leaves, cures well and commands a good price. Pkt., 10c; oz., 40c; 1/4 lb., $\$ 1.25$.

\section{Aromatic, Medicinal and Pot Herbs Packets 10c., except where noted}

\begin{tabular}{|c|c|c|c|}
\hline Used for Flavoring & $\begin{array}{c}\text { Oz. } \\
\$ 0.15\end{array}$ & $\begin{array}{r}1 / 4 \mathrm{lb} . \\
\$ 0.50\end{array}$ & $\begin{array}{c}\text { lb. } \\
\$ 1.50\end{array}$ \\
\hline Broad Leaves ...... & .15 & .50 & 1.50 \\
\hline . Used for Flavoring and Salads....... & .15 & .50 & 1.50 \\
\hline . Leaves Used for Dysentery.......... & .15 & .50 & 1.50 \\
\hline Seeds Used for Flavoring. & 15 & .25 & .75 \\
\hline . Leaves Used for Flavoring. .......... & .15 & .50 & 1.50 \\
\hline s Used for Flavoring. . . . . . . . . & .15 & .50 & 1.50 \\
\hline$\ldots \ldots \ldots \ldots \ldots$ & .15 & .25 & .75 \\
\hline Flavoring.......... & .15 & .30 & .90 \\
\hline c Flavor. & .15 & .40 & 1.25 \\
\hline for $\mathrm{Co}$ & .35 & 1.15 & 4.0 \\
\hline Used for Perfume. & .40 & 1.25 & 4.50 \\
\hline Leaves Used for Flavoring......... & .30 & .90 & 3.00 \\
\hline .For Flavoring. 100 Seeds, 30c..... & & & \\
\hline Heads Very Fragrant.. & .35 & 1.15 & 4.00 \\
\hline . A Highly Aromatic Herb......... & .25 & .75 & 2.50 \\
\hline or Sumer & .15 & .50 & 1.5 \\
\hline the & .35 & 1.15 & \\
\hline . . Has Medicinal Quality............. & .30 & .90 & \\
\hline
\end{tabular}




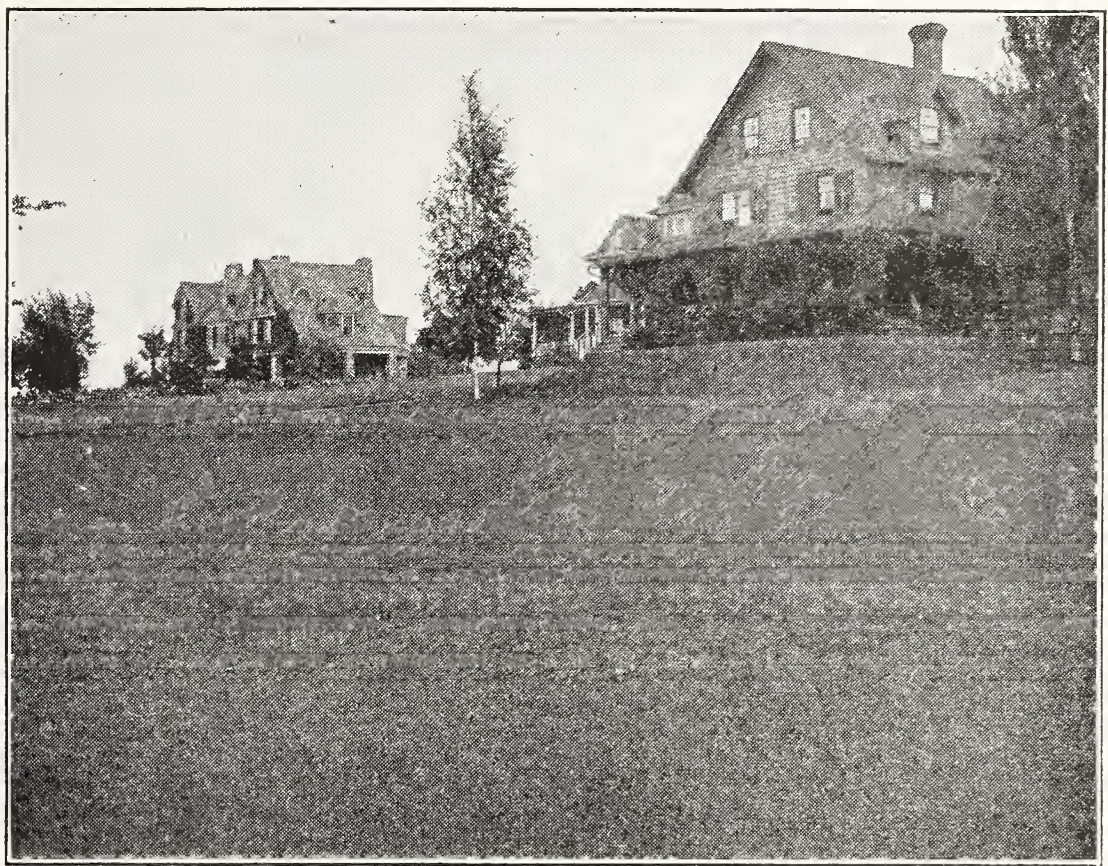

\section{A beautiful lawn like this can be made by sowing Buist's Evergreen Lawn Grass Seed FORMATION OF LAWNS FROM SEED}

When a lawn or park is properly seeded, the next most important feature is the grass which covers it; for no matter how beautiful a lawn is situated and planted, if it lacks this one requisite, it ceases to be attractive. To accomplish this, pay great attention to the preparation of the soil. It should be ploughed, sub-soiled and crossploughed; the surface properly graded and finely prepared, taking care to collect every weed or root of a weed that can be found. Sow the seed in the months of March or April in the Spring, and from the latter part of August to the end of September in the Fall. What kind of seed to sow, and where to get it, is the next question, as all that is called lawn grass seed is by no means the same; for some of those who prepare it are entirely ignorant of the growth and nature of the various varieties of grasses, and are frequently led into errors that prove ruinous to the lawn. An error of this kind involves a great loss and disappointment to the owner, and is almost irreparable; therefore, procure your seed from an experienced and reliable house.

After preparing the ground as directed, sow the seed at the rate of four or five bushels to the acre; cover in with a light seed-harrow, or thin branches tied together to serve the purpose of harrowing, and give the whole a light roll with a field or lawn roller. Our finest mixed lawn grass, which we prepare, is well known for its superior quality in producing a succession of verdure throughout the whole season. Early and frequent mowing is the secret of your after success, which gives strength and stability to the sward. During the warm Summer months do not cut close, and permit the mown grass to lie on the lawn, as it will greatly strengthen the roots and prevent the young grass from being burned out. And as a top dressing or manuring, never use stable manure, as it always contains seeds of weeds, but apply pure bone meal, or what is still better, Buist's Lawn Enricher, at the rate of 400 to 600 pounds per acre. A coating of bone meal and wood ashes applied in the late Fall is very beneficial, and gives the grass a good start in the Spring.

\section{BUIST'S LAWN ENRICHER}

\section{Odorless and Quick Acting}

Buist's Lawn Enricher is an ideal fertilizer for the lawn. Acts quickly, goes direct to the roots and stimulates them to activity. The result is a beautiful dark green lawn, which will remain green and velvety all season. Broadcast at the rate of 400 to 600 pounds per acre. 5 lbs., 35c,; 10 lbs., 60c.; 25 lbs., \$1.10; 50 lbs., \$2.00; 100 lbs., \$3.50; sack of 200 lbs., $\$ 6.00$; ton, $\$ 50.00$. 


\section{BUIST'S LAWN GRASS 'SEEDS}

\section{BUIST'S EVERGREEN GRASS SEED}

This mixture has long been famous for producing a succession of verdure through. out the year. It is composed of the finest varieties of grasses, each of which has its season of beauty, and the result of this blend. ing is the producing of a sod that is not only always evergreen and velvety in appearance, but of the color and beauty of an emerald. Many of the more famous lawns of our coun. try were seeded down with the Buist's Evergreen, the preparation or formula of which is a specialty with our house, which many years of experience suggested. It requires four to five bushels to sow an acre, or for renovating old lawns, about half that quantity. Qt., 30c; 4 qts., $\$ 1.00 ;$ pk., $\$ 1.75$; bu., $\$ 6.50$.

\section{BUIST'S “EMERALD GREEN” GRASS SEED}

A perfect blended combination of fine bladed, compact, quick growing grasses. The ingredients of this mixture are the highest grade of recleaned seed only, carefully proportioned to maintain a rich velvet green color from early Spring to late Fall. Qt., 35c; 4 qts., \$1.25; pk., \$2.25; bu., $\$ 8.00$.

\section{"SHADY NOOK" GRASS SEED}

It has always been very difficult to secure a grass seed mixture that would make a lasting growth in shaded places, especially under trees, but our Shady Nook mixture has over. come this trouble, and can be depended upon to supply this long-felt want; it is comprised of a selection of the finest grasses, which do especially well in shaded or sheltered situations and will quickly produce a fine sward. It requires four bushels to sow an acre. Qt., 35c; 4 qts., $\$ 1.25$; pk., $\$ 2.25 ;$ bu., $\$ 8.00$.

\section{BUIST'S TERRACE GRASS SEED}

A combination of grasses best adapted for sloping ground and terraces, producing strong spreading roots, withstanding drought, thriving in shallow soils, and preventing washing out by heavy rains; producing at the same time a beautiful green turf throughout ine season. To keep in good condition the grass should not be cut too often or too closely. Qt., 35c; 4 qts., \$1.25; pk., \$2.25; bu., $\$ 8.00$.

\section{BUIST'S LAWN RESTORING GRASS SEED}

Compounded from grasses which take firm hold and grow rapidly on hard wornout lawns or on burnt spots. The best time to re-sow is very early in the Spring, or seed may also be sown with excellent results in the Fall, during the month of September. Qt., 35 c; 4 qts., $\$ 1.25$; pk., $\$ 2.25$; bu., $\$ 8.00$.

\section{BUIST'S CENTRAL PARK GRASS SEED}

This variety is a combination that will pro. duce a permanent and lasting turf, a good mixture, free from weeds and chaff, suitable for various soil conditions, always giving good results in light as well as heavy soil. Recom. mended for terraces and exposed places, also for reseeding bare places. Qt., 25c; 4 qts., 75c; pk., \$1.50; bu., \$5.50.

\section{BUIST'S “SEASHORE” GRASS SEED}

A special mixture of grasses peculiarly suited for seaside lawns, composed of strong rooted varieties, which will quickly produce a good turf. In preparing the ground before the seed is sown, it should be top dressed with about four inches of good soil to enable the young roots to get a start; after which the long roots dive deeply down in the sand for moisture. To keep in good condition, the lawn should be watered every evening, and an occasional application of bone meal or Buist's Lawn Enricher will insure a thrifty growth of emerald green. Qt., 35c; 4 qts., \$1.25; pk., $\$ 2.25$; bu., $\$ 8.00$.

\section{PUTTING GREEN GRASS SEED}

Golf courses require a mixture of grass seed which will give a smooth, level compact turf. Our long experience in the blending of grass enables us to select those best adapted for this purpose. Buist's Putting Green Mixture, of fine high-grade grasses, will make a close, firm, green and lasting turf which will improve with use. Sow 5 bushels to the acre. Qt., 65c; 4 qts., \$2.25; pk., $\$ 4.00$; bushel of $25 \mathrm{lbs}$., $\$ 15.00$.

\section{FAIR GREEN GOLF COURSE MIXTURE}

The grasses in this mixture will produce a rich green turf and will resist tramping and hard wear and will retain its color during the severest drought. Sow 5 bushels to the acre. Qt., 30c; 4 qts., $\$ 1.00 ;$ pk., $\$ 1.75 ;$ bu., $\$ 6.50$.

\section{BUIST'S "SUNNY SOUTH" LAWN MIXTURE}

A special preparation that will resist extremes of heat and drought; this mixture has given satisfactory results and by proper care and continual watering, a beautiful lawn can be had in the Southern States, where grasses do not usually thrive during the Summer months. Qt., 30c; 4 qts., \$1.00; pk., \$1.75; bu., $\$ 6.50$.

\section{BERMUDA GRASS}

A very valuable grass in the warmer climates; as a lawn grass it is much used in the South with excellent results. Resists extreme drought during the hot seasons. Does not thrive north of North Carolina. Seed should be sown at rate of 10 lbs. per acre. Lb., 70c; 5 lbs., \$3.25; 10 lbs., $\$ 6.00$. 


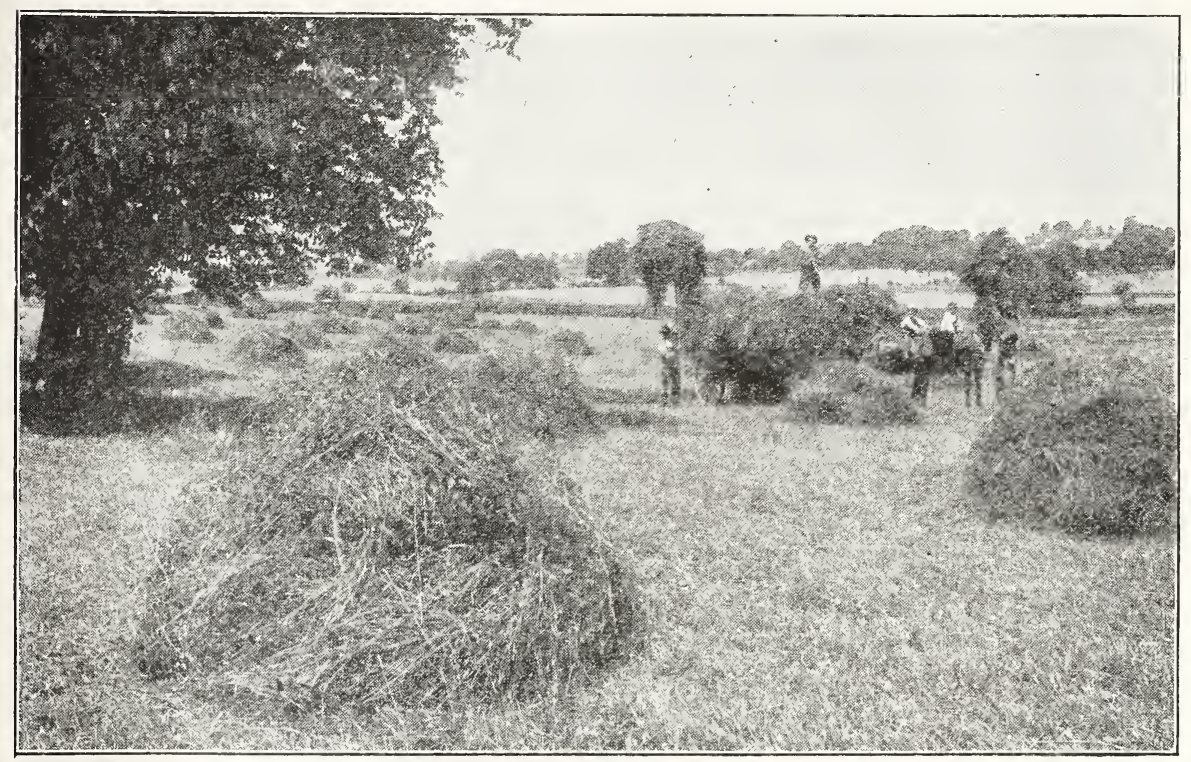

\section{Buist's Special Grass Seed Mixtures FOR} HAY OR PERMANENT PASTURE

\footnotetext{
$\mathrm{T}$ HE demand for our Special Mixtures of Grass Seeds for hay and permanent pasture is very rapidly increasing. The old custom of seeding down to clover and timothy alone must in a few years give way, to a very large extent, to the more improved method of mixing or blending the varieties of Grasses to be sown. When we state that the modern preparations will produce twice as much per acre as timothy and clover, it is no exaggeration. It would therefore be great folly for the agriculturist not to adopt it, or at least experiment with a trial, to a moderate extent, until he becomes convinced of the great advantage to be derived from it.

In ordering, it is necessary to state the character of soil on which it is to be seeded, that the proportions of the most desirable varieties can be selected for the purpose.

Buist's Permanent Pasture Grass Seed Mixture-Sow 3 bushels per acre. Price per bushel of $20 \mathrm{lbs} ., \$ 6.00 ; 5$ bushels, at $\$ 5.50$ per bushel.

Buist's Permanent Hay Field Grass Seed Mixture-Sow 3 bushels per acre. Price per bushel of $20 \mathrm{lbs} ., \$ 6.00 ; 5$ bushels, at $\$ 5.50$ per bushel.

\section{VARIETIES OF GRASS SEEDS}

Kentucky Blue Grass. Fancy Cleaned (Poa pratensis).-Also known as June Grass. It is one of the most valuable varieties for lawn purposes, and as a fine pasture grass is indispensable. It thrives in dry soils and retains its verdure during the hottest weather; it is the famous Grass of Kentucky, and is regarded as the most valuable of all varieties. It is especially valuable from the fact that it starts early in the Spring and furnishes good grazing until late in the Fall. It requires, however, two to three years to become established, and should, therefore, be sown with other grasses. Our stock is the finest, heaviest and best matured seed, thoroughly recleaned. For lawns, sow three to four bushels per acre, and for pasture, from two to three bushels per acre. Lb., 40c; 10 lbs., $\$ 3.50 ; 100 \mathrm{lbs}$., $\$ 32.00$.
} 
Canadian Blue Grass (Poa Compressa)A celebrated Canadian variety, where it is grown very extensively for pasture and hay; it is also known as the Flat Stalked Meadow Grass. It grows from one to two feet high, and has a bluish cast. Will thrive in any soil. Lb., 35c.; 10 lbs., $\$ 2.60 ; 100$ lbs., $\$ 23.00$.

Carpet Grass-A very valuable pasture grass for the South. It grows on poor, sandy soil, and thrives vigorously on most any soil if moisture conditions are favorable. For lawns and golf course it makes a heavy sod and the closer it is cut the better it grows. Sow $10.1 \mathrm{bs}$. to the acre for pasture; $20 \mathrm{lbs}$. for lawns, parks, etc. Lb., 40c.; 10 lbs., $\$ 3.50 ; 100$ lbs., $\$ 30.00$.

Crested Dog's-tail (Cynosurus Cristatus) - This is a most valuable permanent pasture grass. It is very tender and nutritious, the roots penetrate deeply into the ground, which enable it to stand severe droughts. It makes a good bottom grass and is valuable in mixtures for lawns and putting-greens. Lb., 40c.; 10 lbs., $\$ 3.50$; 100 lbs., $\$ 32.00$.

Creeping Bent Grass (Agrostis stoloni fera)-An excellent variety for lawns, succeeding well in moist situations; produces a dwarf, velvety growth. Lb., 90c.; 10 lbs., $\$ 8.50 ; 100$ lbs., $\$ 80.00$.

Fescue, Hard (Festuca Durtuscula)-Valuable for permanent pasture on poor lands, doing well on sandy and siliceous soils. Very hardy, thrives well in dry situations. Lb., 35c.; 10 lbs., \$3.10; 100 lbs., $\$ 28.00$.

Fescue, Meadow, or English Blue Grass (Festuca pratensis) - A valuable variety for permanent pasture or hay; it is very fragrant. Lb., 30c.; 10 lbs., \$2.60; 100 lbs., $\$ 23.00$.

Fescue, Red or Creeping (Festuca Rubra) -An excellent bottom grass, forming a close and lasting turf. It resists extreme drought and thrives on very inferior soils. Lb., 40c.; 10 lbs., \$3.50; 100 lbs., $\$ 32.00$.

Fescue, Sheep's (Festuca Orina)-Is one of the best varieties for sheep pastures, and is used in all preparations of grasses in England for that purpose; is short and dense in growth. Lb., 35c.; 10 lbs., $\$ 3.10 ; 100$ lbs., $\$ 28.00$.

Orchard Grass (Dactylis Glomerata)One of the most desirable and earliest varieties of grasses for sowing in orchards, pastures or in shady places. It grows rapidly, thrives in loamy land, and does not suffer from close feeding. Lb., 35c.; 10 lbs., $\$ 2.90 ; 100$ lbs., $\$ 26.00$.
Red Top, or Herds Grass (Agrostis Vulgaris)-This is one of the most valuable varieties for pasture or for using in lawn preparations, it luxuriates in moist, rich ground, but will thrive in any soil. Highly recommended for land that will not grow Kentucky. Blue Grass.

Red Top Fancy Recleaned-This grade of seed is entirely free from chaff. For pasture sow 15 lbs., for lawns sow 25 lbs. per acre. Lb., 35c.; 10 lbs., \$2.90; 100 lbs., $\$ 26.00$.

Red Top Unhulled-For lawns sow 40 lbs. per acre. Lb., 25c.; 10 lbs., $\$ 1.85$; 100 lbs., $\$ 16.00$.

Rough Stalked Meadow Grass (Poa Trivialis)-Thrives on rich, moist land and in sheltered places, but not on dry land. Lb., 60c.; 10 lbs., \$5.50; 100 lbs., $\$ 50.00$.

Rye Grass, English Perennial (Lolium Perenne)-A nutritious permanent grass for meadows and pastures, or for mixing with other grasses for lawns, or for permanent pasture mixtures; it thrives in almost any soil and yields an early and abundant crop. Lb., 25c.; 10 lbs., $\$ 2.00 ; 100$ lbs., $\$ 16.00$.

Rye Grass, Italian (Lolium Italicum)Very desirable for pasture, thriving in any soil, maturing the first season. Recommended for Southern lawns in winter when the Bermuda is dormant. Lb., 25c.; 10 lbs., $\$ 1.75 ; 100$ lbs., $\$ 15.00$.

Rye Grass, Domestic-A valuable grass for pastures and lawns when quick results are required. Thrives well on any soil. Sow 50 pounds per acre. Lb., 20c.; 10 lbs., \$1.50; 100 lbs., \$12.00.

Sudan Grass-One of the greatest drought resisting forage and fodder crops grown. It belongs to the Sorghum family, only more thrifty, growing from four to seven feet high, with small stems and an abundance of broad leaves. It will yield from four to six tons of hay per acre. Broadcast at rate of about fifteen to twenty pounds per acre. Lb., 15c.; 10 lbs., \$1.10; 100 lbs., $\$ 9.00$.

Timothy (Phleum Pratense)-The most valuable of all hay grasses, produces heavy crops, growth very rapid; but is not suitable for permanent pasture, as it runs out quickly. Lb., 15c.; 10 lbs., $\$ 1.00$; bu. of 45 lbs., $\$ 4.00$.

Wood Meadow Grass (Poa nemoralis) Well adapted for either pastures or pleasure grounds, having a pure succulent and nutritive herbage of early growth, and thrives well under trees. Lb., 75c.; 10 lbs., $\$ 6.50 ; 100$ lbs., $\$ 60.00$. 


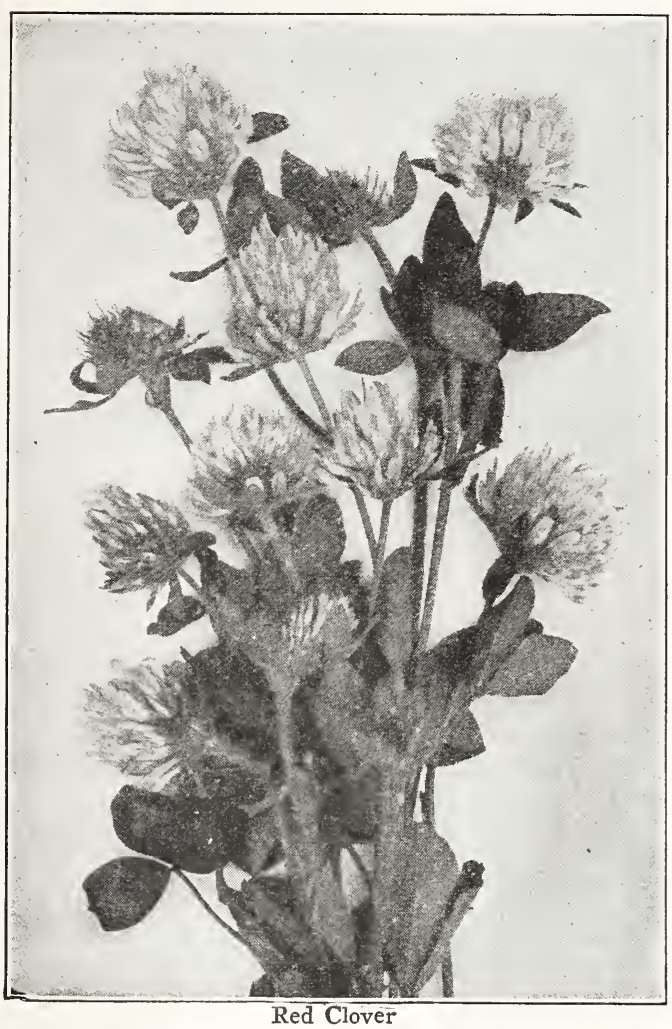

Alfalfa Clover or Lucerne-The most valuable forage crop, now grown successfully in every State of the Union. It is a legume, taking free nitrogen from the air and storing it up in the deep growing root. It will succeed on any good lnamy soil, but the land must be well and thoroughly prepared for the best results. Alfalfa should always be cut when just commencing to bloom. If the seed is allowed to form, the growth of the plant ceases. March and April is the best time to sow in the Spring, and the later part of August and during September, in the Fall. Sow at the rate of 20 to $25 \mathrm{lbs}$. to the acre. Lb., 35 c.; 10 lbs., $\$ 3.00$; bushel price quoted on request.

White Dutch Clover (Trifolium Repens) - This is largely used in lawn and permanent pasture mixtures. It makes a small, close, compact growth. Sow 10 to $12 \mathrm{lbs}$. per acre if alone or $4 \mathrm{lbs}$. with other grasses. The seed we offer is of the highest grade. $\mathrm{Oz} ., 10 \mathrm{c} . ; \mathrm{I} / 4 \mathrm{lb}$., 20c.; lb., 60c.; 5 lbs., $\$ 2.75$; 10 lbs., $\$ 5.00$.

\section{CLOVER SEEDS}

We clean all our Clover Seeds by the most improved machinery. They are entirely free from all weeds and dirt, and are of the very finest grade.

Red Clover (Trifolium Pratense)Regarded as the most valuable farm crop, and is used largely for pasturage and hay. Clover adds greatly to the fertility of the land on which it is grown. It does not exhaust the soil, but enriches it, adding humus and nitrogen, thereby providing rich food for the crops which follow. It makes two crops each year and is very nutritious. Fifteen pounds of seed to the acre. Lb., 35c.; 10 lbs., $\$ 2.75$; bushel price quoted on request.

Alsike, or Swedish Clover (Trifolium Hybridum) - A very valuable variety, which resembles the Red Clover in growth and habit. Valuable in preparations for hay and permanent pasture; very hardy, resisting extreme of heat and drought and also severe cold weather to a remarkable extent; thrives equally as well on wet or dry soils; of very luxuriant growth; sweet and nutritious. A good honey plant for bees. Lb., $35 \mathrm{c}$; 10 lbs., $\$ 3.00$; bushel price quoted on request.

White Bokahara or Sweet Clover (Melilotus Alba)-Sweet Clover is valuable in the bringing up of old waste and wornout soils, and thrives well even on extremely poor soil. If plowed under it adds humus and nitrogen to the soil. Sweet Clover's greatest value, other than a fertilizer, is in preparing the soil for Alfalfa, as the bacteria of Sweet Clover is the same as that of Alfalfa. No other clover will build up land like Sweet Clover. Sow $15 \mathrm{lbs}$, to the acre. Lb., 20c.; 10 lbs., \$1.50; bushel price quoted on request.

Crimson, or Scarlet Clover (Trifolium incarnatum) - An annual of strong, erect growth, providing large crops of green forage; or, if cut while in bloom, will make excellent hay. By plowing the crop under it will make the land rich, fill it with humus and increase the yield of corn or other crops to follow. Sow 15 pounds to the acre. Lb., 20c.; $10 \mathrm{lbs}$., $\$ 1.60$; bushel price quoted on request.

The market on Clover Seed is constantly fluctuating and the prices quoted here are subject to changes. Write for latest prices. 


\section{DWARF ESSEX RAPE}

An English Forage Plant of Great Value to the Farmer and Planter

The sheep and cattle farmers of Great Britain regard Essex Rape as an indispensable crop, and it can be seen growing on almost every farm. It is a forage plant of the greatest value, of rapid growth, yielding from twenty to twenty-five tons of green forage to the acre, which affords the finest pasture for sheep, hogs, cattle and poultry - they always thrive and fatten on it. It is perfectly hardy and in the Southern States can be sown from August to April. In the North sow from March to May and from August to October. Give stock access to salt while feeding on rape.

It makes an excellent salad or "Greens," and can be grown as a substitute for turnip greens; it is extensively planted in the South for that purpose. Sow 8 to 10 pounds per acre broadcast and 4 pounds in drills. Lb., 20c; $10 \mathrm{lbs}$., $\$ 1.50 ; 50 \mathrm{lbs}$., $\$ 5.50$.

\section{HAIRY OR WINTER VETCH (Vicia Villosa)}

The Vetch is another very valuable forage plant, which has been grown very extensively in England and Germany for many years, and cannot be recommended too highly to the farmers and planters of this country. Judging from the increased demand the past year, many have already been impressed with its great value. Sow broadcast from July to October, at the rate of twenty-five to thirty pounds per acre, with three pecks of wheat, rye or oats, which will support the Vetch; greatly increasing its growth and keeping it from the ground; it should be cut for a hay crop just as the grain has headed out, or when it is still in a milky state. Lb., 20c; 10 lbs., $\$ 1.50 ; 25$ lbs., $\$ 3.50 ; 100$ lbs., $\$ 13.00$.

\section{COW PEAS}

The great soil improvers. Makes poor land rich. Makes good land more productive. Also makes a splendid and nutritious green forage or hay crop, enriching the soil even when the crop is cut off

THERE is no surer or cheaper way of improving the soil than by sowing Cow Peas. The 1 plant is a legume, and through the agency of the nitrogen producing bacteria on its roots adds this valuable plant food to the soil, much cheaper than it is possible to obtain in any other way. Cow Peas make excellent hay; if planted by the middle of May, in the latitude of Philadelphia, a crop can be cut and cured for hay same as clover, then stubble with its new growth may be turned under as a fertilizer. Sow $1 \frac{1}{2}$ bushels to the acre.

"Peas could be made to bring more nitrogen to the soils of this country every year than is now purchased annually by the farmers at the cost of millions of dollars." - Year book of the U. S. Department of Agriculture.

Following are the best varieties. As prices fluctuate, write for prices if wanting in quantity:

\section{WHIPPOORWILL}

An early, upright growing variety; makes a good growth of vine, more largely used and sold than any other sort. Write for prices.

\section{GRAY CROWDER}

A large speckled pea, early to mature, very prolific, a splendid land improver, and valu, able as a forage crop; makes an enormous yield of rich, nutritious food. Write for prices.

\section{SOUTHERN BLACK EYE}

A very prolific early sort, vines erect. Very popular in the South, where the peas are used both in a dry and green state for the table. Write for prices.

\section{CANADA FIELD PEAS}

Valuable in the Northern climate for cattle feeding. Excellent for horses and pigs, when sown with oats. Sow broadcast and harrow in at the rate of two bushels per acre. Peck, $\$ 1.25$; bu., $\$ 4.50$.

\section{MAMMOTH YELLOW SOJA BEANS}

Very desirable as a forage crop, producing immense quantities of nutritious feed besides being an excellent soil improver and will withstand drought better than any other forage crop. Sow broadcast at rate of 1 to $11 / 2$ bus. to the acre or plant in drills $31 / 2$ feet apart, half bushel per acre. Write for prices. 


\section{SUNDRY FARM SEEDS}

Prices are subject to Market Changes

BUCKWHEAT-New Japanese-The kernels are larger than the common kind, the straw stouter and heavier, a very heavy cropper and less liable to blight than other sorts. It makes the finest flour. Per tb., 15c; pk., 75c; bu., \$3.00.

BROOM CORN-Weber's Improved Evergreen-Best variety for general cultivation on account of color and quality of brush, ripens very early, grows about 8 to 10 feet high, brush of good length and handsome appearance and shows almost no red. Lb., 25c; pk., $\$ 1.40$; bu., $\$ 5.00$.

BARLEY-Six Rowed-A stiff straw, heavy yielding, six rowed bearded variety. An im. provement over the old Manshury in time of maturity, has plumper kernel and weighs more to the measured bushel. In stiffness of straw and rust resistance it is superior to any other variety. Two bushels will seed an acre. Per pk., 90c; bu., \$3.00.

KAFFIR CORN-Excellent fodder plant, green and dried, and the grain is valuable for feeding poultry. It grows from 4 to 5 feet high and is a tremendous producer of seeds; sown broadcast, 6 tbs., to acre. Per tb., 10c; pk., \$1.00; bu., $\$ 3.50$.

MILLET-Golden (Tennessee Grown)-In the North, Millet is sown altogether for hay, and for that purpose the Southern grown is the best, it grows taller and finer than the Western, making better hay, the Western Millet being coarse and dwarf. Sow one bushel to acre. Per bu., \$3.00.

MILLET-Hungarian - Especially valuable on account of the short season required to make a crop. It can be sown as late as August 1st and yields a heavy crop of excellent hay, only recommended, however, for sowing on low lands or rich soil. Valuable when hay is short or to follow some early harvested crops; sow one bushel per acre. Per bu., \$3.00.

MILLET-Pearl or Cat Tail (Pencillaria)The best known and most valuable of all green forage plants in the South; it is enormously productive, and can be cut several times during the season; also be fed green or cured as dry forage, making a very nutritious food. Sow thinly in rows 3 feet apart at the rate of 10 tbs. per acre. Lb., 20c; 10 tbs., $\$ 1.50$.

MILLET-Japanese Barn-yard-Entirely distinct from all other Millets. It grows 6 to 8 feet high and yields an enormous crop, wrien cured it makes good hay and in quality is superior to corn fodder. Sow in May or June. Broadcast 10 to 15 tbs. per acre, or in drills 8 lbs. It does best on low, moist ground. Lb., 20c; 10 tbs., $\$ 1.25 ; 100$ tbs., $\$ 9.00$.
OATS-Swedish Select-The best early oats, white color, hull thin, the kernel large and plump, straw is stiff and strong. A remarkable root development makes the Swedish Oat a good drought resister; the earliest of the heavy yielding sorts. Per bu. (32 tbs.), $\$ 1.60 ; 5$ bu. at $\$ 1.50$ per bu.

OATS-Canadian Cluster-An enormous yielder producing very large heads, straw stiff, grain plump. Ripens early and not liable to rust. Per bu. (32 tbs.), $\$ 1.60 ; 10$ bu. at $\$ 1.50$ per bu.

OATS-Tartar King-An extremely early White Oat, and heavy cropper, the straw is tall, very strong and holds up well; one of the earliest, heaviest and most prolific sorts; will weigh in a favorable season 40 tbs. to measured bushel. Per bu. (32 tbs.), $\$ 1.60 ; 10 \mathrm{bu}$. at $\$ 1.50$ per bu.

RYE-Spring-Spring Rye is an excellent catch crop where Winter grains have been killed out. Does not grow quite as large straw as Winter Rye, but yields as well and the grain is of finer quality. Sow $1 \frac{1}{2}$ bushels per acre. Per pk., \$1.00; bu., \$3.50.

RYE-Rosen Winter-A new heavy yielding variety, straw is strong, very long, and stands up well. The heads are long and well filled. A distinct improvement over the common rye. Sow $1 \frac{1}{2}$ bushels per acre. Per pk., 75c; bu., $\$ 2.60$.

SUGAR CANE-Early Amber-An early productive variety, heavy yielder of most nutritious matter, can be fed green or cured; stalks tender and filled with a rich sweet sap. Per pk., 90c; bu., \$3.25.

SUGAR CANE-Early Orange-Similar in growth to Early Amber, but requires a longer season to mature. Pk., \$1.10; bu., \$3.75.

SUNFLOWER - Mammoth Russian - Produces large heads and yields twice as large a crop of seed as the common sort, highly recommended for poultry. Oz., 5c; 1b., 15c; 10 tbs., $\$ 1.25 ; 100$ lbs., $\$ 10.00$.

TEOSINTE-A valuable, continuous cutting forage plant; native of Central America. It grows 8 to 12 feet high and somewhat re, sembles Indian Corn, leaves longer and broader, while the stalk contains a sweet sap, can be cut through the Summer until frost. Cultivate same as corn. Sow $4 \mathrm{tbs}$. to acre. 1/4 tb., 30c; tb., $\$ 1.00 ; 5$ tbs., $\$ 4.50 ; 10$ tbs., $\$ 8.50$.

VETCH-Spring-Not as hardy as Winter Vetch. It is a wonderful soil-builder and gatherer of nitrogen, makes fine hay of high feeding value. Sow with oats, using $30 \mathrm{lbs}$. of each per acre. Lb., 20c; 10 tbs., \$1.25; 100 tbs., $\$ 9.00$. 


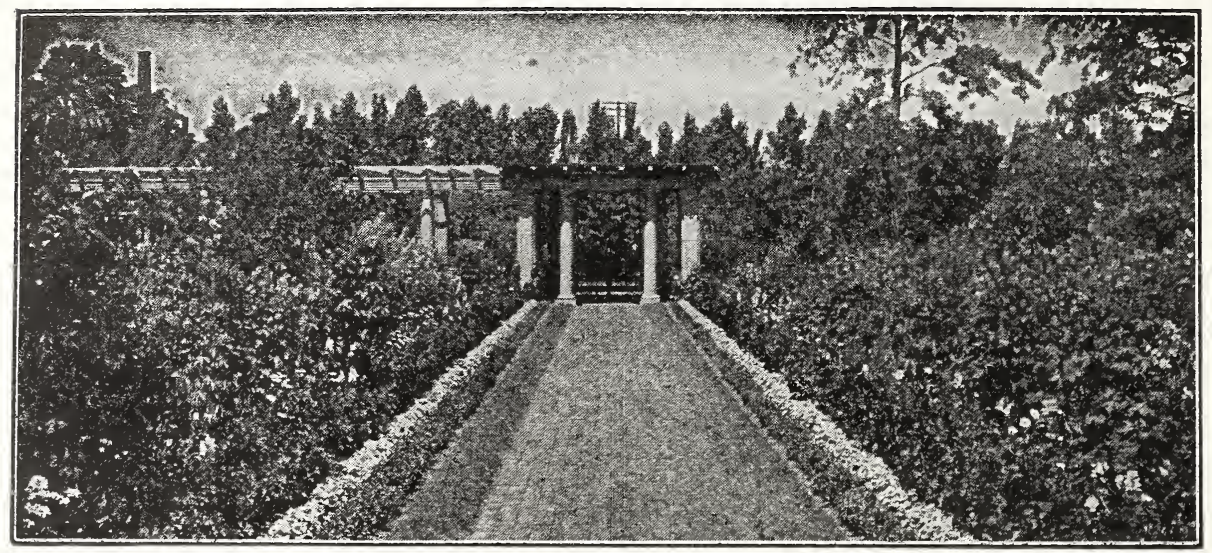

\section{Cultural Directions for Flower Seeds}

$\mathrm{T}$ $\mathrm{HE}$ very general attention that is being given to the cultivation of Flower Seeds requires a few suggestions for the guidance of the inexperienced, who generally blame any misfortune that may occur in their vegetating or growing on the poor seeds and seedsman. We do not pretend to say that they are always exempt from blame, for we are convinced that there are many seeds sold that are perfectly worthless; yet when we hear of a novice who sowed his Calceolarias in the garden and planted his Stocks like Peas, we cannot help thinking that the mis. fortune more frequently occurs from the im. proper treatment than from inferior seeds. Care should be taken not to sow before the ground becomes slightly warm, say, during the month of May about Philadelphia. The soil should be well pulverized, and, if possible, turned up before Winter, and on no account work it in wet weather. The strength of the plants and their ability to produce a profuse bloom, will depend mostly upon the richness of the soil; therefore work into it thoroughly rotted manure, or, what is better, mould formed from decayed leaves. There are two ways of sowing seeds; the one in the border where they are intended to remain; the other in prepared beds, from which they are trans. planted to the Flower Garden. The former plan, although the one most generally adopted, has many inconveniences, one of the principal of which is the ground is occupied for a long period before they arrive at perfection. It would, therefore, be more advis. able, if it were possible, to sow all Annuals in prepared beds, and afterwards transplant to the Flower Borders; but there are some that will not bear transplanting, but these exceptions are few. There should also be discretion used in their sowing; for instance, small delicate seeds should merely be sown on the surface, some barely pressed into the soil, and others fully one-fourth of an inch deep; in most cases, a slight sprinkle of dampened moss will cause them to vegetate more freely, and prevent the surface soil from becoming baked; but as soon as the plants appear, it should be removed. When the seedlings are up, they should be carefully and sufficiently thinned out to prevent their being injured by crowding, and when a few inches high, re move them to the Flower Borders. Tall growing varieties should, when necessary, have neat supports, to prevent damage from wind and rain; this additional care will be amply repaid in the duration and beauty of the plants.

The following general rules apply to all:

Make the surface of the soil as fine, smooth and level as possible; do not plant when the ground is wet; cover each lot of seeds to a uniform depth, which should not be more than four to six times the diameter of the seed; press the soil firmly over the seed; plant in rows so that the starting plants can be seen easily; thin out the young plants to pre. vent crowding and keep entirely free from weeds.

ANNUALS are exclusively raised from seed. They attain perfection and last for one season only; they are divided into three classes-hardy, half-hardy and tender. Hardy Annuals are such as will stand a severe frost, half-hardy are more delicate, and tender Annuals will perish with the slightest frost.

BIENNIALS are those plants that flower the second year from sowing of the seed, and then perish

PERENNIALS are herbaceous plants which die down during the Winter, and spring up and bloom the follow. ing season; they should be covered late in the Fall with well-rotted manure, which should be dug about the roots in the Spring. Tender Perennials should be dug up and stored away free from frost, and planted out in early Spring. 


\section{General Descriptive List of}

\section{Buist's Selected Flower Seeds}

UR list has been carefully revised and a number of new and meritorious sorts added. We have also eliminated some of the older varieties that have been superseded by improved strains of newer introductions, making our list now consist of only the most desirable varieties of Flower Seeds and such as the average amateur gardener can grow with perfect success.

The varieties we offer are the very best obtainable from the most expert growers in Europe and the United States.

Customers will find it convenient to order Flower Seeds by number. This will facilitate the filling of orders and will insure prompt shipment.

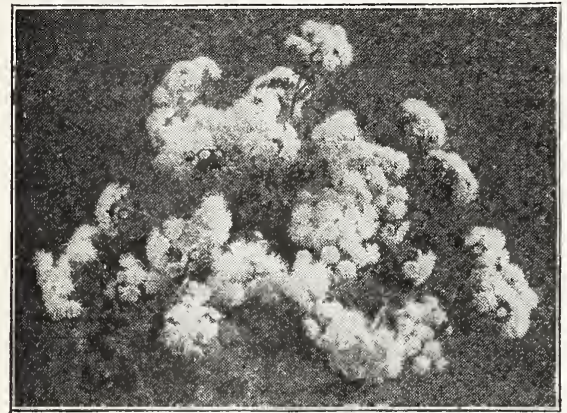

Ageratum Blue Perfection

\section{ABUTILON}

(Flowering Maple)

A tender shrub with handsome maplesshaped foliage and bright bell-shaped flowers. For garden, green. house or indoors. $3 \mathrm{ft}$.

1010 Fine Mixed ........................., 20c

\section{ACHILLEA}

1021 Ptarmica "The Pearl." Double white flowers in clusters. A desirable hardy perennial, June to frost. $2 \mathrm{ft} . . . \ldots \ldots \ldots \ldots \ldots \ldots \ldots$. Pkt., 20c

\section{ACONITUM}

(Monkshood)

1032 Napellus. Panicles of helmet-shaped blue and white flowers. An excellent perennial for borders. June to July. $4 \mathrm{ft}$. .......Pkt., 15c

\section{ACROCLINIUM}

\section{(Everlasting)}

A half-hardy annual, producing double daisy-like flowers, white and rose colored. The blooms may be cut before full open and dried for Winter bouquets. Sow the seed in open ground early in Spring, thin the young plants to 4 inches apart. July till frost. 15 inches.

1043 Double Mixed. $1 / 4$ oz., 25c..........Pkt., 10c

\section{AGERATUM}

\section{(Floss Flower)}

Half-hardy annuals, largely used in beds and borders. They bloom during the whole Summer and provide an ample supply of cut flowers. The plants may also be lifted and will bloom indoors in Winter.

1076 Blue Perfection. Darkest flowers of all the blue Ageratum, compact growth, fine bedder. 9 in. $1 / 4$ oz., 40c.......................... 10c 1087 Little Blue Star. $A$ tiny and compact variety only 4 to 5 inches high, densely covered with light blue flowers. Fine for edging ...Pkt., 25c 1110 Imperial Dwarf White. The best dwarf white. 9 in. $1 / 4$ oz., 30c................. Pkt., 10c

1121 Imperial Dwarf Blue. Clear blue. 9 in.

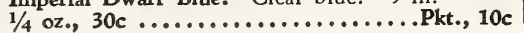

\section{AGROSTEMMA}

A hardy perennial that blooms the first season from seed. The flowers are produced freely on long stems; foliage silvery. $2 \mathrm{ft}$

1143 Coronaria (Rose Campion) Pink ........Pkt., 10c 1154 Coronaria Alba. White.............Pkt., 10c

\section{ALYSSUM}

A dainty little annual plant, useful for borders, for edging a path, or for massing in small beds. The flowers come in early Spring and continue to bloom profusely all Summer.

1165 Little Gem or Carpet of Snow. Flowers pure white on plants about 4 in. high.

$1 / 4$ oz., 20c; oz., 50c................ Pkt., 10c

1187 Sweet Alyssum (Maritimum). The old time favorite Sweet Alyssum. Pure white. 9 in. $1 / 2$ oz., 15c; oz., 25c..................... 5kt

1188 Lilac Queen. Deep lavender-lilac blooms.

6 inches. 1/4 oz., 25c............Pkt., 10c

1198 Saxatile Compactum (Basket of Gold). Silvery foliage, with showy golden yellow flowers from April to May. A perennial that will bloom the first season if seed is sown early indoors. $1 \mathrm{ft}$. $1 / 4$ oz., 30c........................... $10 \mathrm{c}$

\section{AMPELOPSIS}

\section{(Japan or Boston Ivy)}

1232 Veitchi. A hardy perennial climber. The foliage is olive-green, turning to scarlet in Autumn, self-clinging to wood or masonry. $40 \mathrm{ft} .1 / 2$ oz., $25 \mathrm{c} . . . \ldots \ldots \ldots \ldots \ldots . .$. . Pkt., $10 \mathrm{c}$

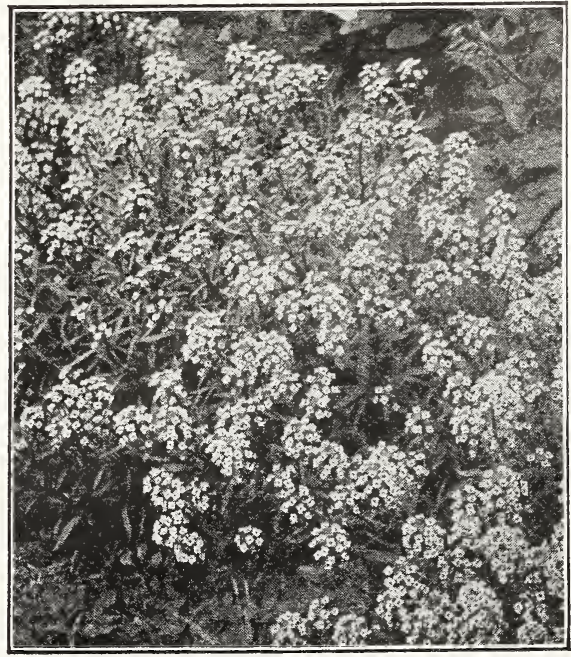

Sweet Alyssum 


\section{ANTIRRHINUM}

(Snapdragon)

They are the aristrocrats of the garden. There are few flowers that compare with Snapdragons for their many gorgeous colors, exquisite form and all-around usefulness. Their continuous blooming qualities, ease of culture and bright colors entitles them to a place in every gar. den, being fine for both bedding and cutting purposes.

For Summer flowering, sow the seed indoors in March and trans, plant to the open ground in May. The plants should be set 9 inches apart each way.

To have good straight ste $\mathrm{m} \mathrm{s}$, each plant should bei staked to support the large b 1 o o m s. Seed pods should never be allow. ed to form, and flowering stalks, after blooming, should be prompt. ly removed. Snapdragons flower continuously from July until November.

\section{GIANT FLOWERED}

A wonderful improvement over the tall, large-flowering strains previously grown, in vigor of growth, size, color and profusion of blooms. They grow $21 / 2$ to 3 feet high, much taller than the Half-Dwarf varieties, and have still larger flowers, closely placed on the stems.

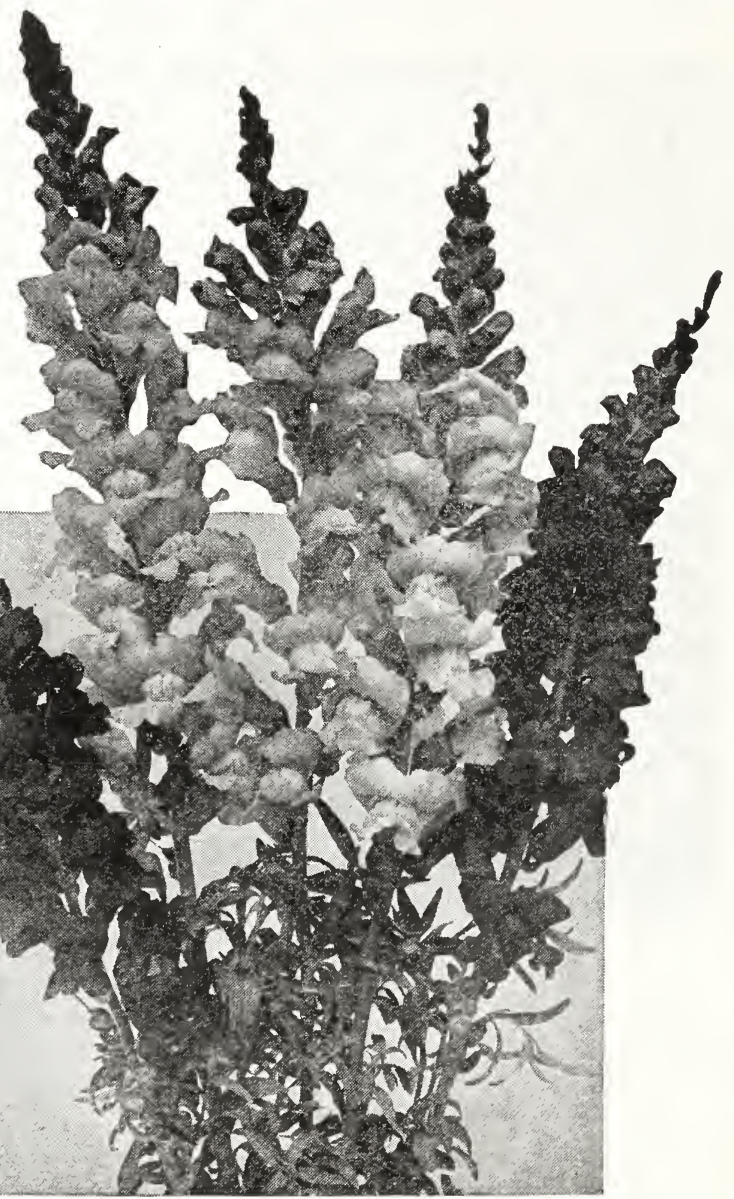

1255 Ruby. Velvety ruby red.............Pkt., 15c

1256 Golden Glow. Bright deep golden-yellow with pink throat ............................ 15c

1257 Apple Blossom. A delicate pink.......Pkt., 15c

1258 Nymph. Rosy lilac, white tube........Pkt., 15c

1259 Purple King. Bright purplish red........Pkt., 15c

1260 Snowflake. Snow white.................... 15c

1261 The Rose. Bright rose pink................ 15 c

1262 Indian Summer. Velvety copper.......Pkt., 15c Any of the above, $1 / 8$ oz. ..............6.

1263 Collection. Pkt. each of above.........\$1.00

1264 New Giant Mixed. 1/4 oz., 50c........Pkt., 15c

TALL FLOWERING. The old-fashioned tall type. Height $3 \mathrm{ft}$.

1321 Mixed. $1 / 4$ oz., 30c.................. 10c

HALF-DWARF VARIETIES produce as large flowers as the tall sorts and are particularly good for bedding, requiring no staking. 1 to $1 \frac{1}{2} \mathrm{ft}$.

1332 Cottage Maid. Pale coral pink.........Pkt., 10c

1333 The Fawn. Rose and gold...........Pkt., 10c

1334 Fascination. Pearly pink self..........Pkt., 10c

1343 Defiance (Bonfire). Russet red.........Pkt., 10c

1354 Fire King. Deep red..................... 10c

1365 Golden Queen. Rich yellow................... 10c

1376 Pink Gem. Rose pink..............Pkt., 10c

1387 Queen of the North. Pure white.....Pkt., 10c

1398 Scarlet King. Brilliant scarlet................, 10c

Any of the above, $1 / 4$ oz. .............40c

1409 Collection. Pkt. each of above..............75c

1410 Half Dwarf Mixed. $1 / 4$ oz., $30 \mathrm{c} . . . .$. Pkt., 10c

Antirrhinum or Snapdragon

\section{AMARANTHUS}

Extremely showy, half-hardy annuals, producing long racemes of curiously shaped flowers, some have gaudy foliage. July to frost.

1209 Caudatus (Love-lies-Bleeding). Long

drooping crimson racemes. $3 \mathrm{ft}$.......Pkt., $5 \mathrm{c}$

1210 Tricolor (Joseph's Coat). Leaves bril liantly marked red, yellow and green.

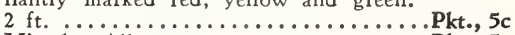

1221 Mixed. "Aill sorts....................... 5c

\section{ANCHUSA}

\section{(Alkanet, Bugloss)}

1233 Capensis (Cape Forget-Me.Not). A hardy an. nual of more than ordinary beauty, with panicled racemes of light porcelain-blue, resembling for. get-me-not flowers. June to September. 18 in. $1 / 4$ oz., 25 c............................ 10c

1234 Italica, Dropmore Variety. A splendid hardy perennial of the richest gentian-blue, blooming during May and June. $3 \mathrm{ft}$. $1 / 4$ oz., $40 \mathrm{c}$; Pkt., 10c

\section{ANEMONE}

\section{(Windflower)}

Hardy perennial, blooming from early Spring until June. Fascinating flowers are in varying colors, blue, red and white with blue stamens, and are double, semi-double or single. $2 \mathrm{ft}$.

1243 Coronaria. Mixed colors.................. 10c 1254 St. Brigid. Single and double................, 15 c 


\section{ASTERS}

NE of the most popular avorites, producing flowers in profusion in which richness and variety of colors are combined with the most perfect and beautiful forms, and are indis. pensable in every garden, or pleasure ground. As a cut flower it rivals the Chrysanthe. mum in beauty and diversity of form and color, and remains firm and fresh for days. They are easily grown, very hardy, and offer themselves for use at a time when other garden favorites are gone. They de. light in a rich, light soil.

For early flowering, sow seed indoors or in cold frame in March, transplant to open ground as soon as danger from frost is past. For late flowering, sow in the open ground in May and transplant when 2 to 3 inches high.

Asters are sometimes attacked by an aphis at their roots; also by stem rot. Both of these troubles are rarely met with if the plants are grown on new soil, and are not checked in their growth. The addition of wood ashes or air-slacked lime at the time of the preparation of the beds also helps to prevent these troubles.

CALIFORNIA GIANT. A new race of Asters which combines the vigorous habit and long stems of the Beauty Type with the wonderful blooms of the Crego Type. It has taken several years of hybridizing and selecting to perfect this new type and it is surely worth all the time and energy required to produce it. The blooms are 5 to $6 \mathrm{in}$. in diameter, of great beauty, the stems are long, strong and without laterals. The California Giant is an ideal florists' flower. 2 to $3 \mathrm{ft}$.

1532 Peach Blossom ........................ 20c

1543 Light Blue ....................... 20c

1555 White ............................, 20c

1565 Deep Rose ............................... 20c

1576 Dark Purple ......................... 20c

Any of the abcve, $1 / 8 \mathrm{oz} . \ldots \ldots \ldots \ldots .60 \mathrm{c}$

1587 Collection. One packet each...........80 c

1598 Mixed Colors. 1/8 oz., 50c................... 15c

GIANT CREGO ASTERS. A new type of American branching varieties. The flowers resemble the Giant Comet Aster, but usually are larger and with longer petals. In beauty the Giant Crego Asters rival the chrysanthemum. This type is known also as the "Ostrich Plume" because of the light feathery appear. ance. $2 \mathrm{ft}$.

1765 White. Pure white..................Pkt., 10c 1776 Pink. Shell pink....................., 10c

1787 Purple. Bright purple.................... 10c 1798 Rose. Rose pink........................ 10c

1809 Lavender. Deep lavender.............Pkt., 10c

1810 Azure Blue. Beautiful.................... 10c

1821 Crimson. A rich color ................. 10kt., 10c Any of the above, $1 / 8$ oz., $40 \mathrm{c}$; $1 / 4$ oz., $60 \mathrm{c}$

1832 Collection. One packet each............50c

1843 Mixed Colors. $1 / 8$ oz., 30c; $1 \% 4$ oz., 50c; oz., $\$ 1.50$.............................. 10 c

\section{HEART OF FRANCE ASTER}

2154 This beautiful variety is unquestionably the larg. est and best dark red Aster. Retains its bril. liancy for a long period. $2 \mathrm{ft}$. .........Pkt., 15c

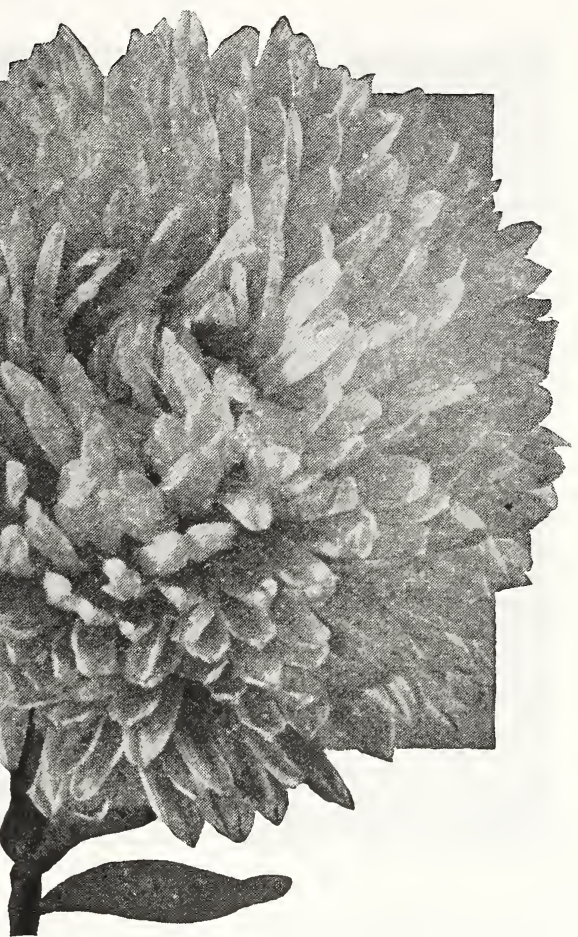

Buist's Giant Beauty Aster

BUIST'S GIANT BEAUTY ASTERS. Similar in form of flowers and habit of growth to the Late Branch. ing Asters. This type differs, however, in that the flowers are produced on longer and heavier stems, 18 to 24 in. long, making them most desirable as cut flowers. $3 \mathrm{ft}$.

2032 Rose. Bright carmine-rose, similar in color to the world-famed American Beauty Rose Pkt., 15c

2043 Purple. A rich deep purple, very large flowers of fine form.......................... 15c

2054 Lavender. A clear soft lavender.......Pkt., 15c

2065 Carmine Rose. Extra large............Pkt., 15c

2076 September Beauty. Shell pink.........Pkt., 15c

2087 White. A giant, pure white..........Pkt., 15c

2098 Collection. One packet each............75c

Any of the above, $1 / 8 \mathrm{oz} . \ldots \ldots \ldots \ldots . . . .50 \mathrm{c}$

2109 Mixed. All colors. 1/8 oz., 40c......Pkt., 15c

GIANT LATE BRANCHING ASTERS. The flowers of this class are extremely large, and borne on long, stiff stems. This class of Aster marks the im provement in the entire group, and it is from the Late Branching that most of the other strains have sprung.

1454 Pure White, Perfect in its purity......Pkt., 10c

1465 Deep Crimson. Rich and glowing......Pkt., 10c

1476 Rose. Rich deep rose..................., 10c

1487 Shell Pink. Soft and dainty..........Pkt., 10c

1498 Royal Purple. Rich deep purple.......Pkt., 10c

1509 Azure Blue. Deep rich lavender.......Pkt., 10c Any of the above, $1 / 8$ oz. ..............30

1510 Collection. One packet each...........50

1521 Mixed. $1 / 8$ oz., 25c; 1/4 oz., 40c......Pkt., 10c

\section{BUIST'S GIANT MIXED}

2165 A magnificent mixture of the most beautiful of the giant sorts, especially selected from the finest varieties, producing beautiful flowers gorgeous in color, gigantic in size. $1 / 8$ oz., 30c; $1 / 4$ oz., 50c; oz., $\$ 1.50$......................Pkt., 10c 


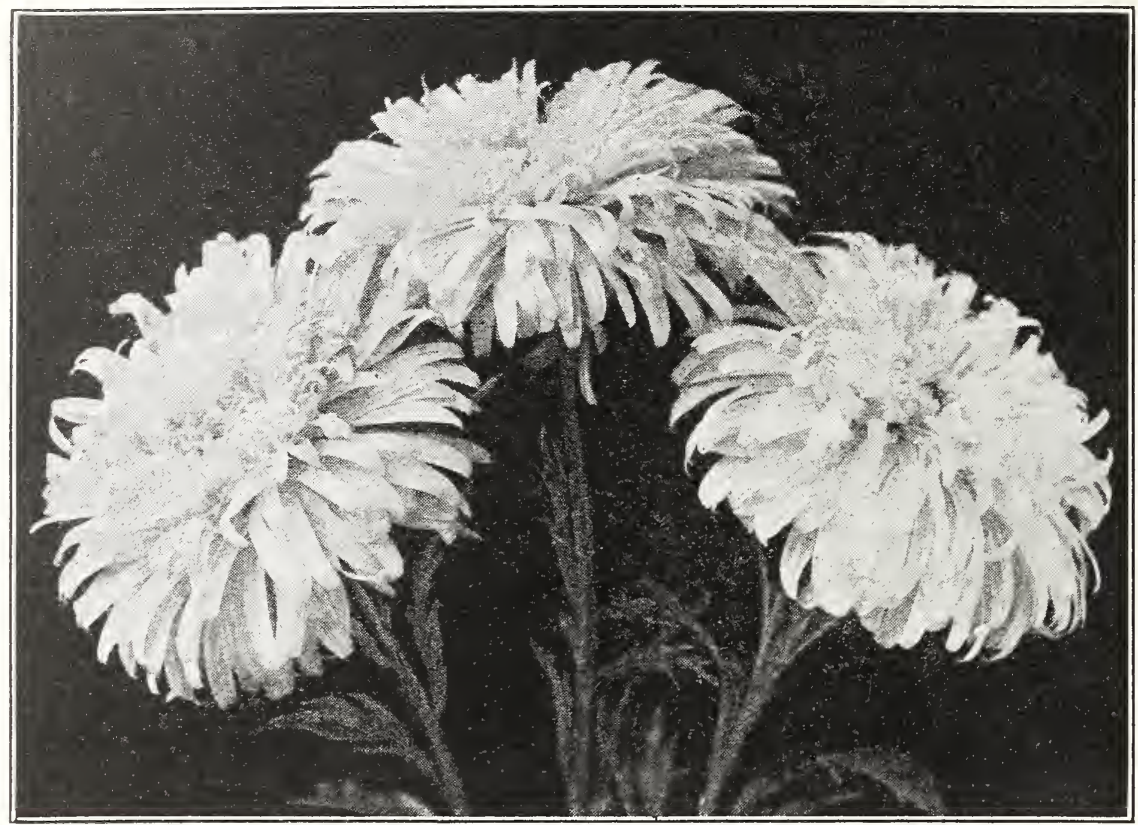

California Giant Aster

QUEEN OF THE MARKET ASTERS. An ex. tremely early blooming Aster, immediately following our Early Wonder Aster. The flowers are borne on long stems which makes them valuable for cutting. 1 to $11 / 2 \mathrm{ft}$.

1610 Bright Rose. A rich color............Pkt., 10c 1621 Lavender. Fine for bunching................. 10c 1632 Crimson. A brilliant crimson................kt., 10c 1643 Blush Pink. An attractive shade.......Pkt., 10c

1654 Purple. Rich deep purple.............Pkt., 10c

1665 White. Snow white....................... 10c Any of the above, $1 / 8$ oz., $30 \mathrm{c} ; 1 / 4$ oz., $50 \mathrm{c}$

1676 Collection. One packet each............50c 1687 Mixed. $1 / 8$ oz., 25c; $1 / 4$ oz., $40 \mathrm{c} . . .$. ..Pkt., 10c

KING ASTERS. An entirely distinct and very desir able type of Aster. The petals are long, narrow and rolled lengthwise, giving them a quilled appearance. The flowers are full double, frequently 3 inches in diameter. $1 \frac{1}{2}$ to $2 \mathrm{ft}$.

1854 Crimson King. Brilliant color.........Pkt., 10c 1865 Lavender King. Lavender blue.........Pkt., 10c 1876 Pink King. Rich soft pink................. 10c

1887 Rose King. Brilliant rose................, 10c

1898 Violet King. Rich purple violet.......Pkt., 10c

1909 White King. Pure white................... 10c Any of the above, $1 / 8$ oz. ...................

1910 Collection. One packet each.............. 1921 Mixed. $1 / 8$ oz., 25c; $1 / 4$ oz., $40 \mathrm{c} . . .$. . Pkt., 10c

GIANT COMET ASTERS. This class is recognized by the long, twisted petals which form loose, yet densely double half-globes, like Japanese Chrysanthe. mums; each plant bears a dozen or more extra large flowers-often 4 inches across-on long stems. $2 \mathrm{ft}$. 1698 White. Pure white.................Pkt., 10c

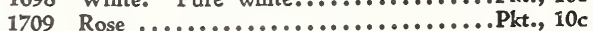

1710 Dark Blue ............................ 10c 1721 Lavender .............................. 10c

1732 Crimson .............................. 10c

Any of the above, $1 / 8$ oz., $40 c ; 1 / 4$ oz. ...60c 1743 Collection. One packet each............40c 1754 Mixed Colors. $1 / 8$ oz., 30c; 1/4 oz., 50c; oz., $\$ 1.50 \ldots \ldots \ldots \ldots \ldots \ldots \ldots \ldots \ldots$. Pkt., 10c
EARLY WONDER ASTERS. The earliest blooming Aster, earlier than the Queen of the Market. The plants are of the Comet type, strong growers, branching and about $18 \mathrm{in.} \mathrm{high.} \mathrm{They} \mathrm{are} \mathrm{very} \mathrm{free} \mathrm{bloomers,}$ carrying the flowers on strong, stiff stems.

2110 White ............................ 15c 2121 Rose .............................. 15c 2132 Dark Blue.......................... 15c

2143 Mixed. All the colors, $1 / 8$ oz., 50c....Pkt., 15c

ASTERMUM ASTERS. A new race developed from the Comet type with branching habit and named "Astermum" because of the size and resemblance to chrysanthemums. The plants are strong, upright grow. ers, and carry ten to fifteen strong stems often 20 in. long.

1987 White. Purest snow white...........Pkt., 10c 1998 Lavender. Rich shade of lavender.......Pkt., 10c 2009 Pink. Rose pink...................... 10c 2010 Collection. One packet each...........25c 2021 Mixed Colors. 1/8 oz., 30c..........Pkt., 10c

GIANT SINGLE ASTERS. A new and attractive variety of single Asters which are becoming very popu. lar. The flowers are large, 3 to 4 inches across, with stems 18 to 24 inches in length, making them wonderful cut flowers.

1934 White $\ldots \ldots \ldots \ldots \ldots \ldots \ldots \ldots \ldots$................. 20c

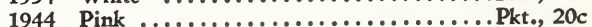

1948 Light Blue .........................., 20c

1964 Lilac ............................... 20c

1975 Dark Blue ........................... 20c

Any of the above, $1 / 8$ oz. .............60

1978 Collection. Pkt. each of above..........80 c

1979 Mixed. $1 / 8$ oz., 50c..................... 15c

\section{HARDY PERENNIAL ASTERS}

This class may readily be raised from seeds and will make an attractive showing in early Autumn. While the plants are perennials, they will bloom the first year if sown early. $2 \mathrm{ft}$.

2187 Mixed Colors .................... 10 


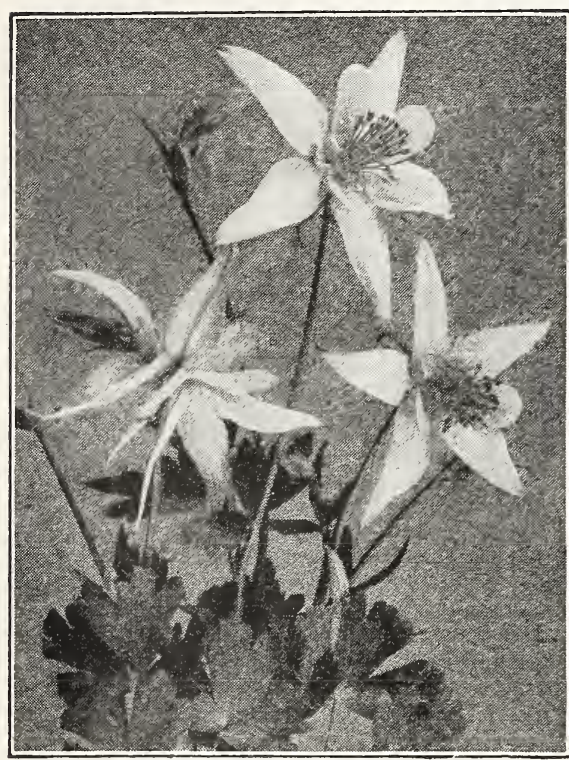

Aquilegia of Columbine

\section{AQUILEGIA \\ (Columbine)}

A favorite hardy perennial, that is of the utmost value for borders or for planting among shrubbery. The flowers are various shades of blue, red and yellow, and are borne from early Spring to Midsummer.

1432 Single Mixed. 1/4 oz., 25c...........Pkt., 10c 1443 Double Mixed. $1 / 4$ oz., 30c.................. 10c 1421 Coerulea. Rocky Mountain Columbine. One of the most beautiful of our American flowers. Violet blue and white. 1/4 oz., 30c...Pkt., 10c

BUIST'S LONG SPURRED COLUMBINES. This strain is the finest of all and contains the best and brightest colors in shades of pink, lavender, scarlet, yellow, white, etc.

1423 Blue and Laverder Shades................... 20c

1425 Pink and Rose Shades.................... 20c

1427 Scarlet and Red Shades................... 20c

1429 Collection. One packet each.............50c

1422 Mixed. 1/8 oz., 50c.................... 15c

\section{ASPARAGUS}

A tender perennial used chiefly for house decorations and conservatory work. The sprays when cut may be used with various cut flowers, remain fresh in water a long time.

2198 Plumosus Nanus. Feathery, fern-like foliage. 100 seeds, 50c........................ 25c 2209 Sprengeri. Drooping feathery foliage with stems 12 to 18 in. long, excellent for hanging baskets. 100 seeds, 25 c.......................... 10

\section{AURICULA}

(Primula Auricula)

The rock garden treasure, that is easily grown. Ex ceedingly fragrant flowers of various colors. Half hardy perennial. 6 in.

2188 Choice Mixed ........................ 25k

BABY'S BREATH. See Gypsophila.

BACHELOR'S BUTTON. See Centaurea.

\section{BALLOON VINE}

\section{(Love-in-a-Puff)}

2210 Half-hardy annual climber. Pure white flowers, followed by seed pods, which look like small balloons. Oz., 25c................Pkt., 10c

\section{BALSAM}

(Lady Slipper)

Double Camellia-Flowered

An old garden favorite which produces gorgeous masses of very double flowers, each of which resembles in form a camellia flower. From July till frost the plants always carry a mass of bloom. The seeds may be sown in flats or in the open ground; later on transplant to the permanent place in the garden.

Annual. $2 \mathrm{ft}$.

2221 Salmon Pink. Very double...........Pkt., 10c 2232 Scarlet. Brilliant fiery scarlet.........Pkt., 10c 2243 Solferino. Striped and spotted........Pkt., 10c 2254 White Perfection ......................... 10c 2265 Royal Purple. Very rich.................. 10ct 2276 The Queen. Pale rose................... 10c

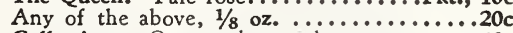
2287 Collection. One packet each...........40 2298 Finest Mixed. 1/4 oz., 25c...........Pkt., 10c

BALSAM APPLE. See Momordica.

BALSAM PEAR. See Momordica.

\section{BEANS}

\section{(Ornamental Varieties)}

2310 Scarlet Runner. Ornamental as well as a useful vine, perfect for summer shade with dazzling flowers. $8 \mathrm{ft}$. ....................Pkt., $5 c$

2321 Jack Beans. Annual climber of rapid growth and free bloomer; good for porches.

Oz., 40c .........................., 5c

\section{BEGONIAS}

\section{(Bedding Varieties)}

The varieties of Begonia Semperflorens here listed are fully as valuable for bedding purposes as are Geraniums and Coleus, and have a touch of novelty not possessed by the other plants. They give a solid mass of bloom. July till frost. Begonias do well in full sunlight and are unsurpassed in partial or full shade. As pot plants for Winter blooming they are superb. $1 \mathrm{ft}$.

2332 Vernon. Bright orange carmine........Pkt., 15c 2343 Erfordia. Rosy carmine flowers........Pkt., 25c

2354 Prima Donna. Rose, shading carmine

at center, ever-blooming...............pkt., 25c

2365 Gracillis Rosea. Delicate rose....... Pkt., 25 c

2376 Luminosa. Fiery scarlet..............Pkt., 25c

2387 Gracillis Alba. Pure white............... 25k

2388 Salmon Queen. Salmon-rose..........Pkt., 25c

2398 Special Mixture. All colors..........Pkt., 15c

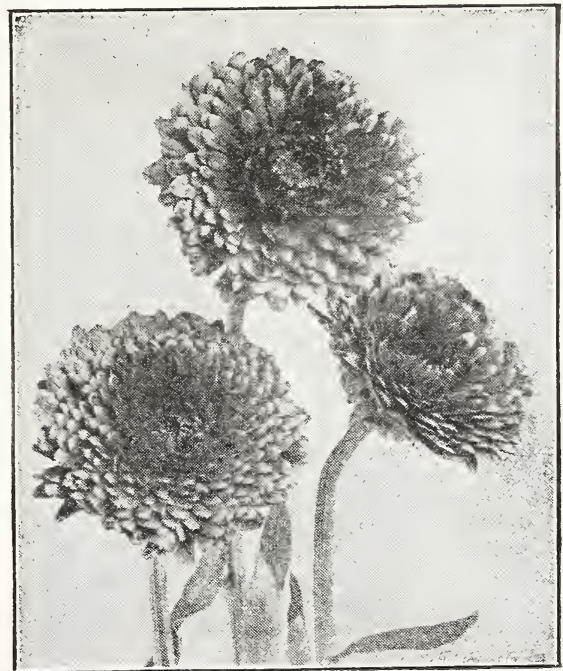

Calendula 


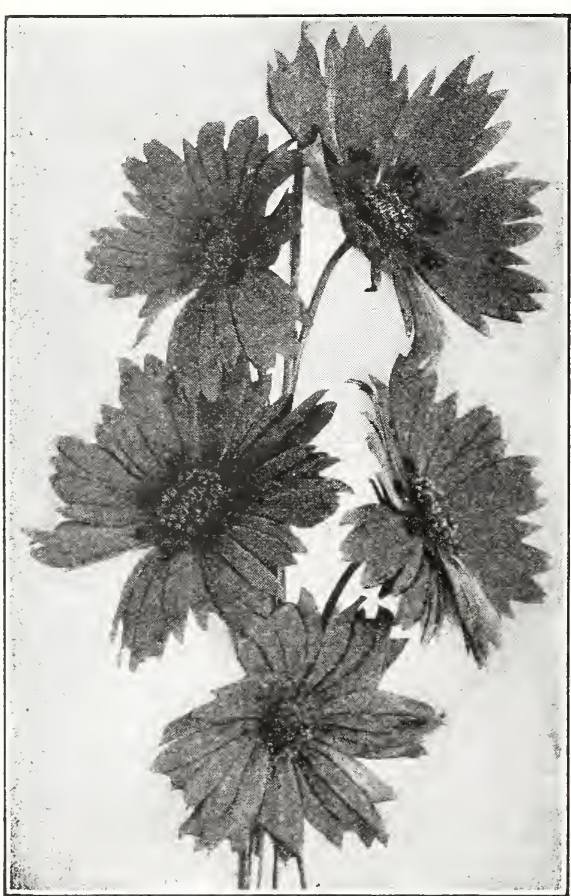

Calliopsis, Golden Wave

\section{BELLIS PERENNIS}

(English Daisy)

Half-hardy perennials about 6 in. high, which are used for bedding and borders. Easily raised from seed sown any time from June to September; trans. planted in the Fall and protected during the Winter, they will flower the following Spring.

2409 Snowball. Double, pure white.......Pkt., 10c

2410 Longfellow. Double, pink...........Pkt., 10c

2421 Double, Mixed .......................... 10c

2432 Monstrosa Alba. Snowy'white.......Pkt., 15c

2443 Monstrosa Rosea. Deep rose.........Pkt., 15c

2454 Giant Double Mixed....................... 15c

BLACK-EYED SUSAN. See Thunbergia.

BLUE LACE FLOWER. See Didiscus.

BOSTON IVY. See Ampelopsis.

\section{BRACHYCOME}

\section{(Swan River Daisy)}

Beautiful blue and white flowers on slender stems borne by graceful, bushy plants, in great abundance all Summer. Half-hardy annual. 9 in.

2465 Mixed Colors ....................... 10c

\section{BROWALLIA}

An exceedingly attractive half-hardy annual for either the garden in Summer or pot culture in Winter; fine for cutting. $11 / 2 \mathrm{ft}$.

2476 Elata, Mixed. Blue and white........Pkt., 5c

2477 Speciosa Major. A beautiful flowering variety of the most brilliant ultramarine blue; a

rare color ........................... 25k

BUTTERFLY FLOWER. See Schizanthus.

\section{CACALIA}

\section{(Tassel Flower)}

A half-hardy annual, easy culture, with tassel-shaped flowers, blooms from July to September; fine for borders. $11 / 2 \mathrm{ft}$.

2487 Mixed Colors. $1 / 4$ oz., 25c........... Pkt., 10c

\section{CALCEOLARIA}

Gorgeous flowered tender annuals, used chiefly for greenhouse or conservatory decoration. Seed sown in August or September will produce blooms in March and April. Require cool house, 35 to $40^{\circ}$ at night. 2498 Hybrida Grandiflora. Mixed colors. The broad, lady slipper flowers are self-colored, or finely spotted, rich yellow, gold and brown...Pkt., 25c

\section{CALENDULA}

(Pot Marigold)

A well-known old-fashioned annual. They are of easy culture and bloom from early Summer till Fall. Valuable also for pot culture, blooming in the Winter and early Spring. $1 \mathrm{ft}$.

2509 Meteor. Creamy white striped orange.

Oz., 30c ........................... 5c

2510 Orange King. Orange-red. Oz., 40c..Pkt., 10c

2512 Lemon Queen. Oz., 40c................., 10c

2533 Nankeen. Very double, creamy yellow, slightly flushed apricot. Oz., 30c.............Pkt., 5c 2534 Favorite. Creamy white. Oz., 30c...Pkt., 5c

2543 Collection. One packet each..........25c

2554 Mixed. Oz., 25c.................... 5k

2556 The Ball. A special florists' strain of Orange

Calendula. Flowers large............Pkt., 20c

CALIFORNIA POPPY. See Eschscholtzia.

\section{CALLIOPSIS}

Among our most showy and free-flowering annuals. The seeds germinate readily, the plants thrive any. where, even in dry, sunny places on poor soils, and produce a prodigious quantity of flowers for cutting all Summer long.

DWARF VARIETIES. 9 to 12 inches.

2565 Crimson King. Rich, dark crimson flowers. 1/4 oz., 30c........................... 10c 2566 Bicolor Nana. $1 / 4$ oz., 20 c...................... 10 2576 Golden Wave. One of the most effective and beautiful sorts; 2-in. rich golden yellow flowers with small chestnut brown center.

$1 / 4$ oz., 20c......................., 10c

2598 Star of Fire. Fiery red cactus'shaped flowers. 12 in. $1 / 8$ oz., 25 c................... $10 \mathrm{c}$

2609 Tiger Star. Rich bronze, striped and mottled yellow. $1 / 4$ oz., 30c..............Pkt., 10c

2610 Tom Thumb Beauty. Golden yellow with crim. son center. Excellent for pots and borders. 8 in. $1 / 4$ oz., 25c................. Pkt., 10c

2611 Collection. One packet each.............50 2621 Mixed. Dwarf. $1 / 2$ oz., 25c................. 10c

TALL VARIETIES.

2632 Nigra Speciosa. Rich reddish maroon. Strong grower. $2 \mathrm{ft} . . . \ldots \ldots \ldots \ldots \ldots . . .$. .......... 10c

2633 Marmorata. Golden yellow and maroon marbled. $1 / 4$ oz., 25c........................... 10c

2634 Bicolor Tinctoria. Very large, bright yellow and maroon blooms. 2 ft. 1/4 oz., 25c; Pkt., 10c

2635 Collection. One packet each..........25c

2636 Mixed. Tall. $1 / 2$ oz., 20c.............. $k$ kt., 5c

\section{CAMPANULA}

(Bellflower)

Dainty bell-shaped flowers thriving best on light, rich soil. All are hardy perennials.

2643 Carpatica Blue. Clear blue, flowers all Sum. mer, especially good for edging. 8 in. $1 / 4$ oz.,

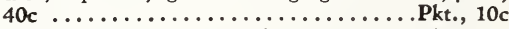
2654 Carpatica Alba. Pure white................ 10c 2665 Pyramidalis Blue (Chimney Bellflower). Spikes 3 to $4 \mathrm{ft}$., pyramidal flowers, large and of beautiful blue ......................... 10c

2676 Pyramidalis Alba. Pure white ........Pkt., 10c

2677 Persicifolia Grandiflora. (Peach Bells.) One of the very best Bellflowers with large, beautiful blue blooms. $3 \mathrm{ft}$....................... 15 c

2678 Persicifolia Grandiflora Alba. White form of above ................................ 15c 


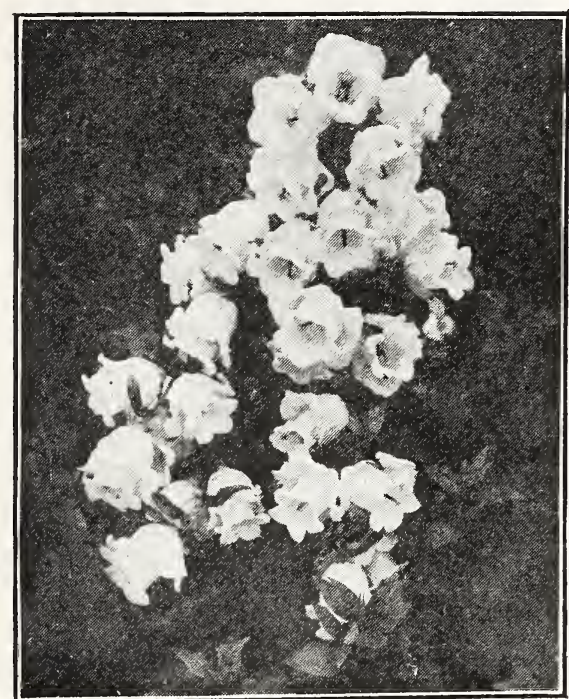

Canterbury Bells

\section{CANTERBURY BELLS \\ (Campanula Medium)}

CALYCANTHEMA (Cup and Saucer). The large single blooms resemble a cup and saucer, hence the name. Hardy biennial, flowering the second year from seed. $2 \frac{1}{2}$ feet high. Sow seed any time up to July 15 th, or if sown very early indoors, it may bloom the first year.

2687 Blue. A clear shade................. Pkt., 10c 2698 Alba. Pure white ........................ 10k 2709 Pink. Delicate rosy.pink................., 10c 2710 Finest Mixed. 1/8 oz., 40c...........Pkt., 10c

MEDIUM (Single Canterbury Bells). A hardy biennial that thrives best in light, rich soil with good drainage. The flowers are bell-shaped.

2721 Dark Blue ........................ 10k

2732 Light Blue .......................... 10c

2743 Rose .............................. 10c

2754 White. A pure white.................... 10c

2765 Single Mixed. 1/4 oz., 25c...........Pkt., 5c

2776 Double Mixed. 1/4 oz., 50c..........Pkt., 10c

\section{CANARY BIRD VINE}

A half-hardy annual that is excellent for quickly covering stumps, rockeries and similar places. It is also excellent for the Winter window garden.

2787 Tropaeolum Peregrinum. Yellow. $1 / 2$

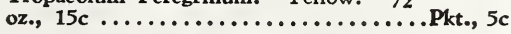

\section{CANDYTUFT}

One of the very best annual flowers for edging beds and borders and for show in the rock garden; it is also a good cut flower. Seed sown outdoors in early Spring blooms July to September. $1 \mathrm{ft}$.

2809 Carmine. Bright carmine-rose......... Pkt., 10c 2810 Crimson. Dark crimson .................., 10c

2821 Lilac. Rosy lavender....................... 10c

2843 Snowflake. Myriads of small, very sweet. scented flowers ........................ 10c

2854 Rose Cardinal. Rosy-red.............Pkt., 10c Any of the above, $1 / 2$ oz. ............25c

2856 Collection. One packet each...........40c

2865 Mixed. All colors. Oz., 25c.........Pkt., 5c

2868 Giant Empress. Extra large, long trusses of pure white flowers. Valuable for cutting. 18 inches high. $1 / 2$ oz., $35 \mathrm{c} . \ldots \ldots \ldots \ldots \ldots \ldots$......... 10c

\section{CANNA}

(Indian Shot)

Usually these plants are grown from roots, but there is a novelty in raising them from seed. The seed must be soaked in warm water for several hours before planting. Half-hardy perennial.

2876 Mixed. Oz., 25c.................... 10

\section{CARNATIONS}

Great favorites and becoming more and more popular every year because of their delicious fragrance and rich ness of colors. Sow the seed in February or eariy March for nice plants to set in the garden when all danger of frost is past. They are best treated as annuals although they are half-hardy perennials. $1 \mathrm{ft}$.

IMPROVED GIANT DOUBLE. Undoubtedly the best Carnation in existence for outdoor culture and the easiest to raise. The very large, double or semi-double. strongly cloverscented flowers are produced continuously, July to frost, if the seed is sown indoors in early Spring.

2897 Blood Red ........................ 20 2908 Yellow ........................... 20c

2909 Rose ............................., 20c 2920 Scarlet ............................... 20c

2931 Flesh-pink ........................., 20c

2933 White ........................... 20c

2935 Collection. One packet each..........\$1.00 2944 Mixed. 1/8 oz., 40c..................., 15c

MARGUERITE CARNATIONS. A very popular Carnation with the amateur as they begin to flower in a few weeks and continue to bloom the remainder of Summer until frost. $1 \mathrm{ft}$.

2954 Marguerite Mixed. 1/4 oz., 40c.......Pkt., 10c 2965 Giant Marguerite. Extra large and perfect flow. ering in a rich variety of colors, including

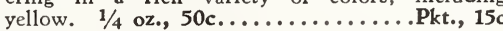

HARDY GARDEN CARNATION. An excellent strain for borders and rock gardens, because of their compact growth. Seed sown in the Spring will produce large clumps, blooming throughout the following Sum. mer and Fall.

2966 Double Mixed. 1/4 oz., 50c..........Pkt., 15c

CARDINAL CLIMBER. See Cypress Vine.

CASTOR OIL PLANT. See Ricinus.

\section{CELOSIA CRISTATA}

(Cockscomb)

Free-blooming, graceful plants, producing large ornamental, comb-like heads resembling ruffled chenille. 1 to $11 / 2 \mathrm{ft}$.

2976 Glasgow Prize. Dark crimson.........Pkt., 10c 2987 Giant Empress. Rich crimson..........Pkt., 10c

2998 Golden Queen. Golden yellow........Pkt., 10c

3009 Dwarf Mixed. 1/4 oz., 30c................. 10c

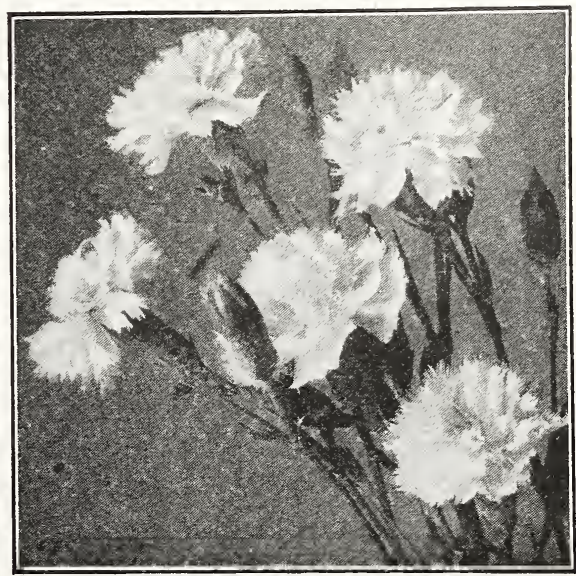

Improved Giant Double Carnation 


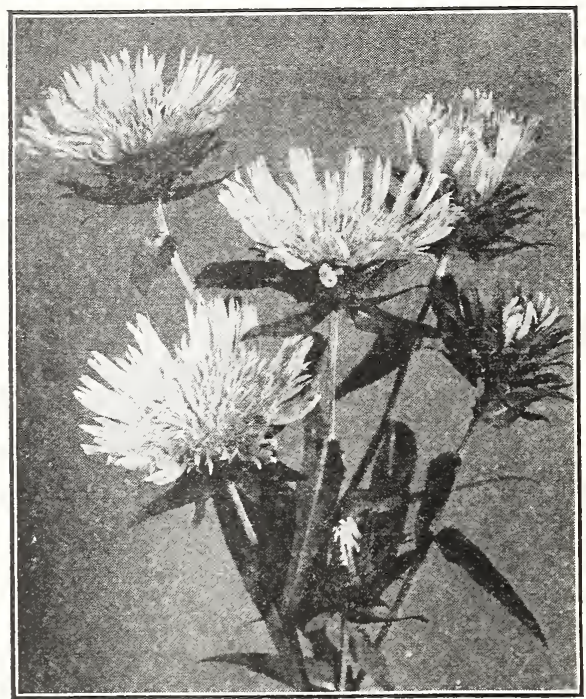

Centaurea Montana

\section{CELOSIA PLUMOSA}

(Feathered Cockscomb)

Radically different from Celosia Cristata, as the blooms of this annual resemble feathery plumes. The plants are from 2 to $3 \mathrm{ft}$. high and usually in bloom all summer. The plumes may be dried for Winter bouquets.

3010 Childsi Crimson (Chinese Woolflower). A dis tinct type of the Plumed Celosia. The plants average $2 \mathrm{ft}$, in circumference. Scores of branches are thrown out bearing ball-shaped flowerheads of a crimson color resembling a ball of soft silky fleece. $1 / 2$ oz., 25c.............Pkt., 10c

3021 Childsi Pink (Chinese Woolflower)

Of the same form as above............Pkt., 10c

3032 Golden Plumes. Golden yellow........Pkt., 10c

3033 Pride of Castle Gould. By far the best strain of the large ostrich-plumed Celosias with flower heads in a wide range of brilliant colors-blood red, real carmine, deep scarlet, wine red, golden yellow, salmon and dark orange, are some of the distinct colors in this strain.

$1 / 8$ oz., 50c...................... 15 c

3043 Plumosa Thompsonii Magnifica. Plants of pyramidal growth. $3 \mathrm{ft}$, bearing large conical heads, ranging in color from the clearest yellow to the darkest red. $1 / 8$ oz., 25c........Pkt., 10c

3044 Plumosa Mixed. $1 / 4$ oz., 25c..........Pkt., 5c

\section{CENTAUREA}

CENTAUREA CYANUS (Cornflower, Bachelor's Button) Also known as Ragged Sailor, Blue Bottle and Ragged Robin. A most delightful old-time annual that blooms all Summer till frost in the most profuse manner. The flowers should be cut often so as to prevent the plants exhausting themselves by seeding. 1 to $2 \mathrm{ft}$. high.

3076 Double Blue ......................... 10 c

3087 Double Rose Pink...................... 10c

3098 Double White ....................Pkt., 10c

3100 Double Maroon ....................... 10kt.,

3102 Double Mauve ......................... 10c

3104 Double Rosy-red ...................... 10c Any of the above, $1 / 4$ oz. 25c.

3106 Collection. One packet each.............50 3109 Double Mixed. 1/4 oz., 20c..........Pkt., 10c
CENTAUREA IMPERIALIS OR GIANT SWEET SULTAN. Big, thistlellike blooms with pleasing fra. grance which are exceedingly valuable for cutting, as they last for many days when placed in water.

3110 Brilliant Rose ........................ 10c

3121 Dark Rose ........................... 10c

3132 Deep Lavender ....................... 10c

3143 Deep Purple ........................., 10c

3154 Delicate Lilac ........................ 10 c

3165 Pure White .......................... 10c Any of the above, $1 / 4 \mathrm{oz} . \ldots \ldots \ldots \ldots . . .30 \mathrm{c}$

3166 Collection containing a packet each of the six

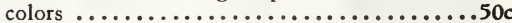

3167 Finest Mixed Colors. 1/4 oz., 25c.....Pkt., 10c

\section{WHITE-LEAVED CENTAUREAS}

3168 Gymnocarpa (Dusty Miller). A favorite peren nial for edging beds and borders. Fine cut silvery gray foliage. $11 \frac{1}{2} \mathrm{ft} . \ldots . . . .$. . Pkt., $10 \mathrm{c}$

3169 Candidissima (Dusty Miller). The downy silvery foliage of these half-hardy perennials is highly priced for bedding, ribbon borders and margins .............................. 10c

\section{VARIOUS CENTAUREAS}

3170 Americana (Basket Flower). An attractive native annual bearing immerse, thistle-like showy blooms often 4 in. across, of rosy. lavender that make fine cut flowers. It is an ideal border plant. $3 \mathrm{ft} . . . \ldots . . .$. . Pkt., $10 \mathrm{c}$

3171 Montana. Beautiful blue hardy Cornflower. July to September. $2 \mathrm{ft}$. $1 / 4$ oz., 30c..Pkt., 10c

3172 Suaveolens (Yellow Sweet Sultan). These big yellow thistle-like, fragrant flowers have a strong appeal; not only as a garden plant are they popular, but the florists find frequent use for the blooms; they last well as cut flowers and in make.up. $1 / 4$ oz., 30c............Pkt., 10c

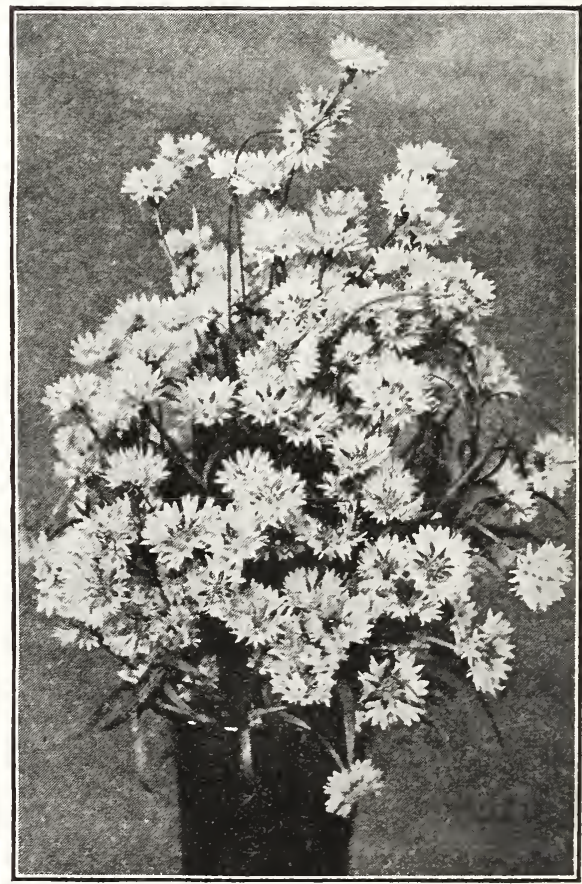

Centaurea Cyanus 


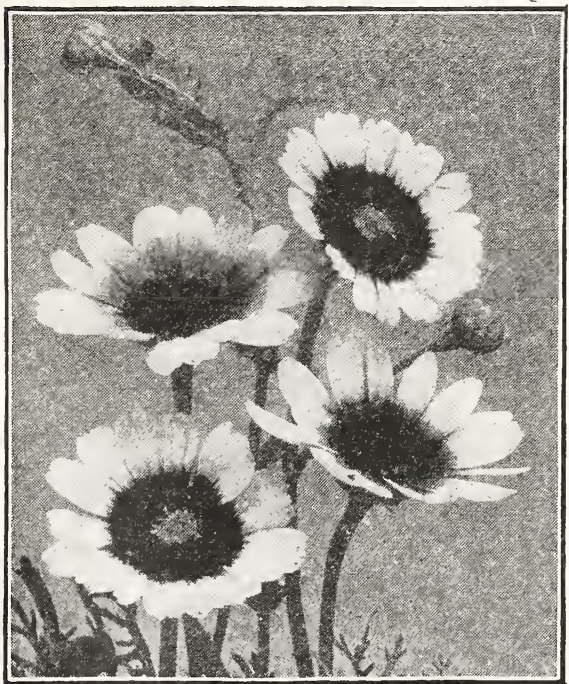

Annual Chrysanthemums

\section{CHRYSANTHEMUM}

Summer-blooming Chrysanthemums are showy and effective in the garden, flowering from June until frost. These are not the well-known Winter varieties sold by florists and which are propagated only by division of roots.

ANNUAL VARIETIES, OR PAINTED DAISIES. These annual Chrysanthemums are unsurpassed as Summer cut flowers. The plants are easily grown from seed, and they bear an inexhaustible supply of big painted daisy-like flowers on good stems from Mid. Summer to frost.

3176 Evening Star or Helios. Golden yellow, center darker ............................... 10c

3187 Morning Star. Primrose-yellow, shading deeper at centers ........................ Pkt., 10c

3198 North Star. Pure white fringed petals. Zones canary-yellow at base about the dark brown eye ............................... 10c

3199 Eastern Star. Clear yellow with deeper yellow zone about the dark center............Pkt., 10c

3200 Atrococcineum Scarlet .............Pkt., 10c

3201 Burridgeanum. White petals, with zone of rich mahogany with inner zone of yellow and brown disc ............................, 10c

Any of the above, $1 / 4$ oz. ...............25c

3202 Collection. One packet each...........40c

3203 Single Mixed. 1/4 oz., 20c........... Pkt., 10c

3204 Coronarium. Double Mixed. Showy hardy an. nuals. 3 to $4 \mathrm{ft}$. $1 / 4$ oz., 20c..........Pkt., 10c

\section{PERENNIAL VARIETIES}

3209 King Edward (Moon-penny Daisy). Large pure white flowers, 3 to 4 in. across. They are of splendid substance and having long stems, are prized for cutting......................., 10c

3210 Japanese Hybrids. Large flowers of the finest type. Seeds sown in Spring will produce flower. ing plants by Fall..................Pkt., 25c

\section{SHASTA DAISIES}

3221 Shasta Daisy. Very large, white single flowers on long stems. $1 / 8$ oz., 30c...........Pkt., 15c

3232 Shasta Daisy "Alaska." This is the finest of all the Shasta Daisies, flowers of immense size. $1 / 8$ oz., 50c............................ 25c

\section{CHINESE LANTERN PLANT}

3238 Physalis Franchetti. This beautiful little plant is grown chiefly for the orange-scarlet lantern. like fruit, which can be cut and dried for Winter bouqets. Although a perennial, the pods are produced the same year from Spring sown seed. $2 \mathrm{ft} .1 / 8$ oz., $25 \mathrm{c} . . . . . . . .$. .Pkt., $10 \mathrm{c}$

\section{CINERARIA HYBRIDA}

A very attractive house or greenhouse plant which blooms freely during the Spring. Seeds are sown in August and grown in a cool place. The colors vary from white to scarlet and crimson, and from light blue to deep blue.

3254 Grandiflora Prize. Splendid mixed varieties, all colors. $2 \mathrm{ft} . . . \ldots \ldots \ldots \ldots \ldots \ldots$............ 25c

3265 Nana. Beautiful dwarf compact varieties mixed. $1 \mathrm{ft}$. plants with very large heads of big flowers.

Pkt., 50c

3276 Stellata (Star Cineraria). A most graceful, beautiful variety, bearing quantities of medium. sized star-like flowers in the same variety of colors as the ordinary Cineraria. Wonderfully decorative plant, also cut flower. $3 \mathrm{ft}$. Pkt., 25c

\section{CINERARIA}

(Dusty Miller)

3287 Maritima Candidissima. Used chiefly for borders and ribbon beds. The foliage is white or silvery. Half-hardy perennial. 1/4 oz., 30c......Pkt., 10c

\section{CLARKIA}

An old time, free growing annual of graceful habit. It is desirable as a border plant and does equally well in the rockery or planted by old walls. Of late years is much used by florists for bouquets. 2 to $21 / 2 \mathrm{ft}$.

3313 Double, Mixed. 1/4 oz., 30c.........Pkt., 10c

\section{CLEOME}

\section{(Spider Plant)}

Unusual formed flowers with long slender threads running out from the center. Seeds sown in the ground as soon as it can be worked. Bloom from Mid.Summer until frost. Annual. $3 \mathrm{ft}$.

3321 Rose or Pink. 1/4 oz., 25c..........Pkt., 10c

\section{COBAEA}

\section{(Cup and Saucer Vine)}

A climber of rapid growth. The flowers are quite large, borne on long stems and are of bell shape. In sowing, place the seed edgewise and merely cover with light soil. To get early results, sow seed indoors in March or April; can also be sown outdoors in May. $20 \mathrm{ft}$.

3343 Scandens. Purple. 1/4 oz., 35c.......Pkt., 10c

3354 Scandans Alba. Pure white.................. 10c COCKSCOMB. See Celosia.

\section{COLEUS}

The most valuable of all the variegated foliaged bed. ding plants. The colors range from green to deep crimson, striped and mottled.

3376 Fine Hybrids ...................... 25c 3387 Choice Mixed ......................... 10 c COLUMBINE. See Aquilegia.

CONEFLOWER. See Rudbeckia.

\section{COREOPSIS}

3410 Lanceolata Grandiflora. One of the most gorge ous and also the most satisfactory of all the perennials for it begins blooming in June, con. tinuing until frost. Golden yellow flowers on long stems. $2 \mathrm{ft}$. $1 / 4$ oz., $25 \mathrm{c} . . . .$. ..Pkt., $10 \mathrm{c}$

3411 Lanceolata Grandiflora. F1. PI. (Double Flower ing Coreopsis.) Similar in habit to above, flowers are double and semi-double. Splendid for cutting. $2 \mathrm{ft}$. $1 / 4 \mathrm{oz} ., 40 \mathrm{c}, \ldots, \ldots, \mathrm{Pkt} ., 15 \mathrm{c}$ 


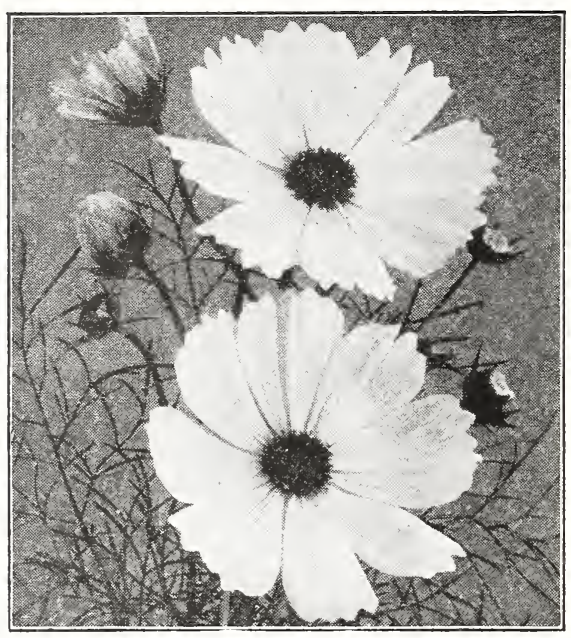

Buist's Mammoth Cosmos

\section{COSMOS}

Grace and brilliancy are the characteristics of Cosmos. They are the most attractive Autumn flowers and a general favorite with all.

MAMMOTH LATE FLOWERING. The glory of the Autumn garden. The gigantic flowers, borne on long stems, and the feathery foliage make them very desirable for bouquets. They are very effective when planted in broad masses or against evergreen and fences. Height 5 to 6 feet.

3421 Pure White ............................. 10c 3432 Crimson ..........................., 10c

3443 Light Pink ........................................ 10c

Any of the above, $1 / 2$ oz. ...................

3487 Collection. One packet each...........25c 3498 Mammoth Mixed. 1/2 oz., 25c; oz., 40c; Pkt., 10c

LATE DOUBLE CRESTED COSMOS. The center of these flowers has the effect of a double crest, having an extra row of petals around the base. They bloom very freely from August until frost. The flowers are very artistic and stand for a long time when cut. Height 5 feet.

3598 Pink Beauty ........................ 15c

3609 Crimson King .................................. 15c

3610 White Queen ......................... 15c

3621 Mixed $1 / 4$ oz., 50c................... 15k

EXTRA EARLY GIANT FLOWERING. This type of Cosmos grows about 4 feet high and if the seed is started in the house or frame, will bloom from six to eight weeks earlier than the Mammoth Flowering. The flowers are of good size and continue to bloom from July until frost.

3510 Early Crimson ...................... 10c

3521 Early Pink .......................... 10c

3532 Early White .......................... 10c

Any of the above, $1 / 4$ oz. ...............

3543 Collection. One packet each...........25c

3554 Mixed. All colors. 1/4 oz., 20c.......Pkt., 10c

EXTRA EARLY DOUBLE CRESTED. A new form which we succeeded in developing from the Late Double Crested Cosmos. It is just as beautiful and blooms from July until frost. They are extremely attractive sorts. Height 4 feet.

3622 Pink .............................. 25c 3623 Crimson ............................. 25c

3624 White ............................ 25c

3627 Gloria. Peach-blossom pink ...........Pkt., 25c

3625 Collection. One packet each.............75c

3626 Mixed ................................ 25c COWSLIP. See Primula Veris.

\section{CYCLAMEN}

Very handsome as well as unique shaped plant and flowers for a house or greenhouse, which blooms in Winter and early Spring. It takes fifteen months to bloom from seed and the plants require loose soil, rich in leaf mold. 6 in.

3632 Persicum. Mixed colors.............Pkt., 15c

3643 Giant Finest Mixed......................... 25c

\section{CYNOGLOSSUM}

\section{(Chinese Forget-me-not)}

3650 Amabile. An annual recently introduced from China, producing sprays of intense blue forget. me-not flowers, delicately sweet scented. $11 / 2 \mathrm{ft}$ $1 / 4$ oz., 40c....................... Pkt., 15c

\section{CYPRESS VINE}

\section{(Ipomcea Quamoclit)}

The foliage of this annual climber is extremely delicate and much resembles the Maidenhair Fern. The seed should be soaked in warm water before sowing. Will grow $15 \mathrm{ft}$. in a season.

3654 Crimson or Scarlet. $1 / 2$ oz., 25c......Pkt., 10c

3665 White. Pure white. 1/2 oz., 25c......Pkt., 10c

3676 Mixed. $1 / 2$ oz., 20c....................., $5 c$

\section{CARDINAL CLIMBER}

3687 This distinct climber is the best of all the annual climbing vines. It is a very rapid grower, attaining a height of $30 \mathrm{ft}$. or more. Its foliage is deeply laciniated, resembling fern foliage, and there is an abundance of fiery-cardinal red flowers from July to frost. $1 / 4$ oz., $40 \mathrm{c} . . . .$. . Pkt., $10 \mathrm{c}$

\section{DAHLIAS}

Growing Dahlias from seed is extremely fascinating; one gets new and interesting forms. Sow seed in February to get plants large enough to set out when danger of frost is past. These seedlings will bloom from July to frost.

3698 Single Giant Perfection. Immense single flowers of various colors................... Pkt., 10c 3709 Double Large-flowering. Saved from fine double show and fancy sorts...................... 15c

3710 Double Cactus-flowered Mixed. Many colors, twisted and curled petals.............Pkt., 15c

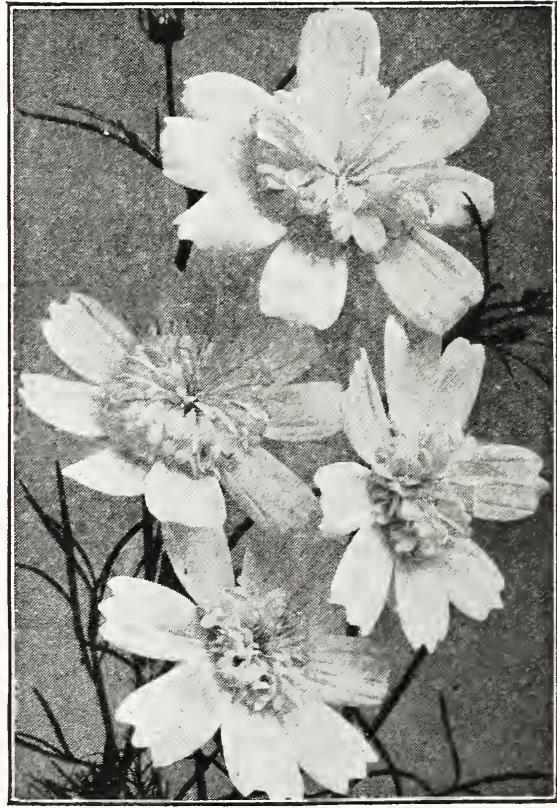

Crested Cosmos 


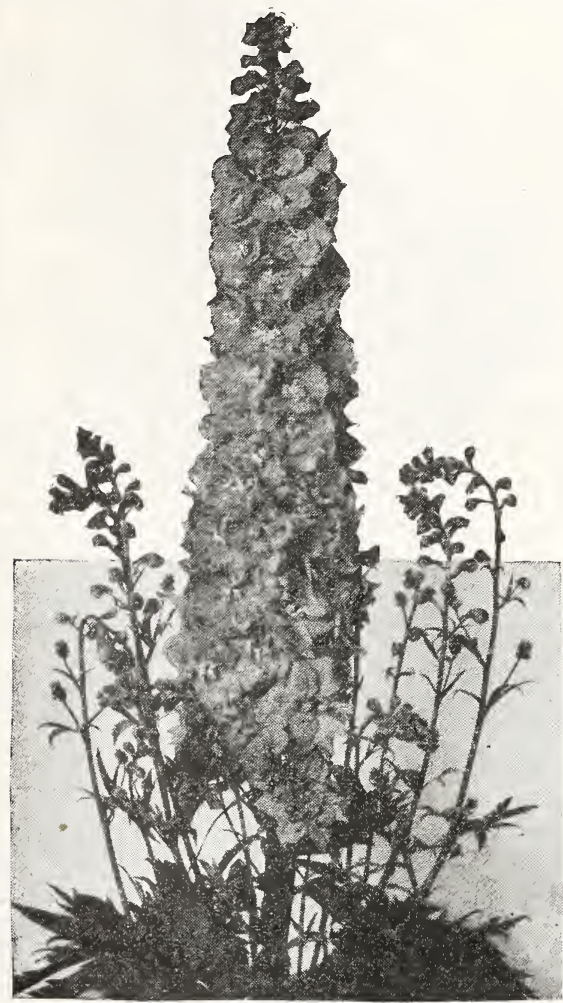

Delphinium

Buist's Gold Medal Hybrids

\section{DELPHINIUM}

(Hardy Larkspur)

One of our most showy and useful hardy perennial plants, possessing almost every requisite for the adorn. ment of the garden. The beautiful flowers, borne on tall stately spikes, are a gorgeous sight and a charm to the garden.

To prolong the season of bloom, cut the old flower stems off after they have faded, and new shoots will flower later in the season.

Start seed in flats in March and later transplant seedlings when $3 / 4$ inches high to 4 inches apart. In May set the plants out in the border where they will bloom in Midsummer. Place mature plants 3 feet apart. 3776 Gold Medal Hybrids. A wonderful improved type of Delphinium. The colors range from palest lavender, through every shade of blue to pansy'violet, several shades being blended in some of the varieties. $1 / 4$ oz., 50c.....Pkt., 15c

3743 Belladonna. One of the most freely and con. tinuous blooming varieties. Immense spikes of lovely pale blue....................... 20 c

3744 Bellamosum. A lovely counterpart to Bella. donna, rich deep blue flowers..........Pkt., 25c

3746 Chinense (Blue Butterfiy). Deeply divided light green foliage, light blue flowers. $1 \frac{1 / 2}{2}$ feet.

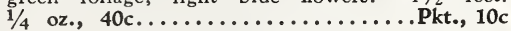

3747 Chinense Album. Pure white flowers. $11 / 2$ feet. $1 / 4$ oz., 40c......................... 10

DAISY, ENGLISH. See Bellis Perennis.

DAISY, SHASTA. See Chrysanthemums.

DAISY, ALASKA. See Chrysanthemums.

DAISY, AFRICAN. See Dimorphotheca.

\section{DIANTHUS}

(Pinks)

Pinks are the most lovable of all the flowers in the garden. They are unrivaled for brilliancy and richness of color. Most of them are hardy perennials which bloom the first season if the seeds are sown early in. doors under glass. Older plants bloom earlier than young plants, but the seedlings bear larger and better flowers the first season. Seed should be sown each Spring. Average height 1 foot.

\section{DOUBLE ANNUALS}

3787 Chinensis (China or Indian Pink). Blooms in clusters, flower very double. All colors.

$1 / 4$ oz., 25 c.......................... 5 c

3788 Mourning Cloak. Flowers very dark velvety crimson, each petal being margined white

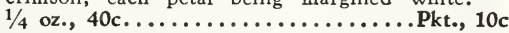

3809 Heddewigi (Double Japan Pink). Colors vary from the richest velvety crimson to the most delicate rose. $1 / 4$ oz., $25 \mathrm{c} . . . \ldots \ldots . .$. . Pkt., $5 \mathrm{c}$

3810 Heddewigi Diadematus fl. pl. (Diadem Pink). Beautiful flowers from 2 to 3 inches in diameter, regular and closely double. All colors.

$1 / 4$ oz., 30c....................... Pkt., 10c

3813 Nobilis fl. pl. (Double Royal Pink). The hand. somest of all the pinks. All colors from white to dark red. $1 / 4$ oz., $50 \mathrm{c} . . . \ldots . . . .$. . Pkt., $10 \mathrm{c}$

3821 Laciniatus, fl. pl. Large, double, showy flowers in variety of colors, fringed edges.

$1 / 4$ oz., 30c........................... 10c

3822 Salmon King. Brilliant salmon-rose.

$1 / 4$ oz., 50c....................... Pkt., 10c

3824 Lucifer. Large double flowers of orange'scarlet color. $1 / 4$ oz., $40 \mathrm{c} . \ldots \ldots \ldots \ldots \ldots \ldots$. Pkt., 10c

3832 Snowball. Large double white.........Pkt., 10c

3843 Fireball. Fiery red. $1 / 4$ oz., $40 \mathrm{c} . . .$. Pkt., 10c

3854 Collection. One packet each...........70c

\section{SINGLE ANNUALS}

3865 Heddewigi (Single Japan Pink). Finest selected single-flowered. 1/4 oz., 25c...........Pkt., 5c

3866 Nobilis (Royal Pinks). Flowers of large size ranging in colors from white to dark red. $1 / 4$ oz., 40c........................ 10 c

3876 Laciniatus. A beautiful fringed variety. Various colors. $1 / 4$ oz., 30c................Pkt., 10c

3877 Salmon Queen. Brilliant salmon rose.

$1 / 4$ oz., 40c......................... 10k

3887 Crimson Belle. $1 / 4$ oz., 40c..........Pkt., 10c

3898 Eastern Queen. Rose. 1/4 oz., 40c...Pkt., 10c

3921 Collection. One packet each...........40c

HARDY GARDEN PINKS. Charming Summer flowering border plants, clove scented; very fragrant; should be planted in every garden.

3923 Cæsius (Chedder Pink). Rosy'pink flowers. Fine for rockeries. $1 / 4 \mathrm{oz} ., 50 \mathrm{c} . . . .$. Pkt., 10c

3932 Plumarius (Pheasant's Eye, Grass Pink). Pretty fringed, single flowers of various colors.

$1 / 4$ oz., 30c..................... Pkt., 10c

3954 Double Scotch Pinks. Double and semi-double. $1 / 8$ oz., 30c.......................... 10 c

3955 Plumarius Semperflorens, fl. pl. Very beautiful, sweet scented, double, semi-double and single flowers in great diversity of colors; blooming the entire season. $1 / 8$ oz., $40 \mathrm{c} . . . \ldots \ldots$...Pkt., $15 \mathrm{c}$

\section{DIDISCUS}

\section{(Blue Lace Flower)}

Very charming outdoor or greenhouse annual. The plant grows about 18 inches high and produces attrac. tive, umbel-shaped flowers of lace-like appearance; the color is a clear cœrulean or heavenly blue. Sow seed where they are to remain, as they do not stand trans. planting. Excellent for cutting.

3956 Coeruleus ....................... 10 c 


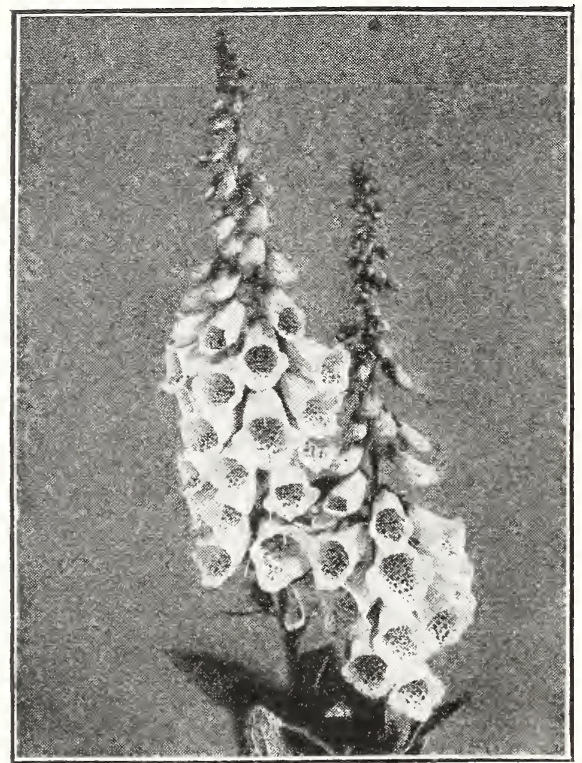

Digitalis (Foxglove)

\section{DIGITALIS}

\section{(Foxglove)}

An old favorite and one of the best hardy herbaceous plants; 3 to $4 \mathrm{ft}$. tall spikes, the upper half of which arc crowded with long, bell-shaped flowers.

GLOXINIAEFLORA. An improved strain of the ordinary Foxglove with handsome Gloxinia-like flowers on long stems. $4 \mathrm{ft}$.

3965 Purple. $1 / 4$ oz., 30c.................. 10c

3966 Rose. $1 / 4$ oz., 30c.................., 10c

3967 White. $1 / 4$ oz., 30c.................., 10c

3968 Mixed. $1 / 4$ oz., 25 c....................... 10

3969 Giant Shirley. Flowers of unusual size, ranging in color from fure white to dark rose, 5 to 7 $\mathrm{ft} .1 / 8$ oz., 30c........................ $15 \mathrm{c}$ 3976 Monstrosa. Splendid, mixed colors.

$1 / 4$ oz., $40 \mathrm{c} . \ldots \ldots \ldots \ldots \ldots \ldots \ldots$................ 10 c

\section{DIMORPHOTHECA}

(African Golden Daisy)

3987 Aurantiaca. A new, very showy annual, bearing an abundance of gorgeous, orange, daisy-like flowers, 3 in. across with black centers. Blooms

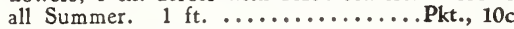

3998 Aurantiaca Hybrids. Beautiful hybrids of the African Golden Daisy. Flowers of various shades, primrose, apricot, buff, salmon and delicately tinted ..................... 10 c

\section{DOLICHOS}

\section{(Hyacinth Bean)}

Tender, rapid-growing, annual climber, flowering freely for covering arbors, trellises, etc.

4009 "Daylight." White. Oz., 25c.......Pkt., 10c 4010 "Darkness." Purple. Oz., 25c.......Pkt., 10c 4021 Mixed. Oz., 20c......................., 5ct.,

\section{DRACAENA}

\section{(Dragon Plant)}

Fast growing foliage plants for window gardens, porches, or greenhouses.

4023 Indivisa. Narrow green leaves.........Pkt., 10c

DUSTY MILLER. See Centaurea and Cineraria.

\section{ESCHSCHOLTZIA}

\section{(California Poppy)}

Eschscholtzias are among our most beautiful and popular annuals, being of the easiest culture. Spring. sown seeds flower profusely July until late Autumn; a valuable bedding plant. Sow the seed where the plants are to remain. $1 \mathrm{ft}$.

4032 Californica. Bright Yellow. Oz., 30c Pkt., 5c 4043 Crimson King. 1/4 oz., 25c.......... Pkt., 10c 4054 Golden West. Flowers very large.

$1 / 4$ oz., 25c.................... Pkt, 10 4055 Chrome Queen. 1/4 oz., 25c...........Pkt., 10c

4056 Rosy Queen. 1/4 oz., 25c...........Pkt., 10c

4057 Scarlet Beauty. 1/4 oz., 25c...........Pkt., 10c

4058 Tango. Bronzy red overlaid with terra-cotta.

$1 / 4$ oz., 25c....................... 10kt.,

4059 Fringed Yellow. $1 / 4 \mathrm{oz} ., 25 \mathrm{c} . . . \ldots \ldots$.... Pkt., 10c

4061 Purple Glow. Bright reddish-purple; the dark. est shade yet obtained. $1 / 4 \mathrm{oz} ., 25 \mathrm{c} . .$. Pkt., 10c

4062 Mauve Beauty. Lavender mauve.

$1 / 4$ oz., 25c....................... Pkt., 10c

4063 Vesuvius. Perfectly self-colored, deep rich crimson. $1 / 4$ oz., 25c...............Pkt., 10c

4064 Collection. A packet of each...........90

4065 New Hybrid Mixed. This recent introduction bears extra large flowers of tints and shades never before seen in Eschscholtzias.

$1 / 4$ oz., 20c....................... 10 ckt.

4066 Double-flowering Mixed. 1/4 oz., 25c..Pkt., 10c

4067 Single Mixed. Oz., 30c............Pkt., 5c

\section{EUPHORBIA}

4076 Variegata (Snow on the Mountain). Attractive light green foliage, veined and margined white; $2 \mathrm{ft} . \quad 1 / 4$ oz., 20c..................... 10 4077 Heterophylla (Annual Poinsetta). Mexican Fire Plant. 2, to $3 \cdot \mathrm{ft}$. bushy plant with dark green leaves, the upper turning bright red...Pkt., 10c

EVERLASTING FLOWERS. See pages: Acrolinium 99, Chinese Lantern 107, Globe Amaranth 111, Helichrysum 112, Rhodanthe 120, Statice 121.

FLAX. See Linum.

FORGET-ME-NOT. See Myosotis.

FOUR O'CLOCK. See Marvel of Peru.

FOXGLOVE. See Digitalis.

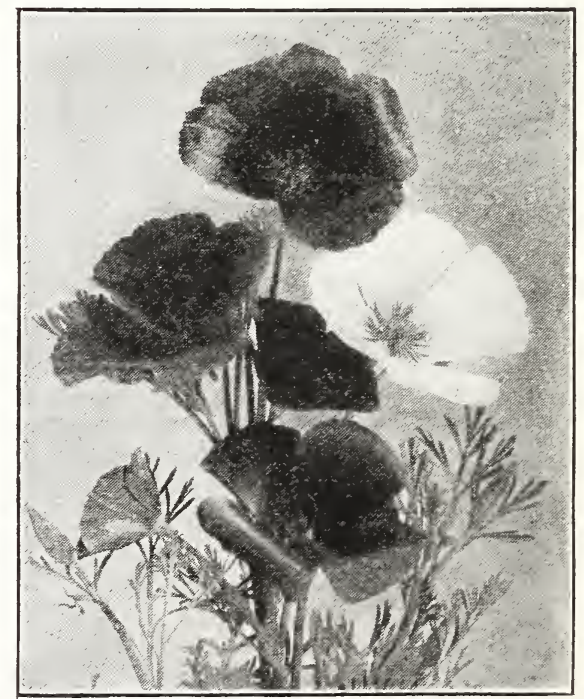

Eschscholtzia (California Poppy) 


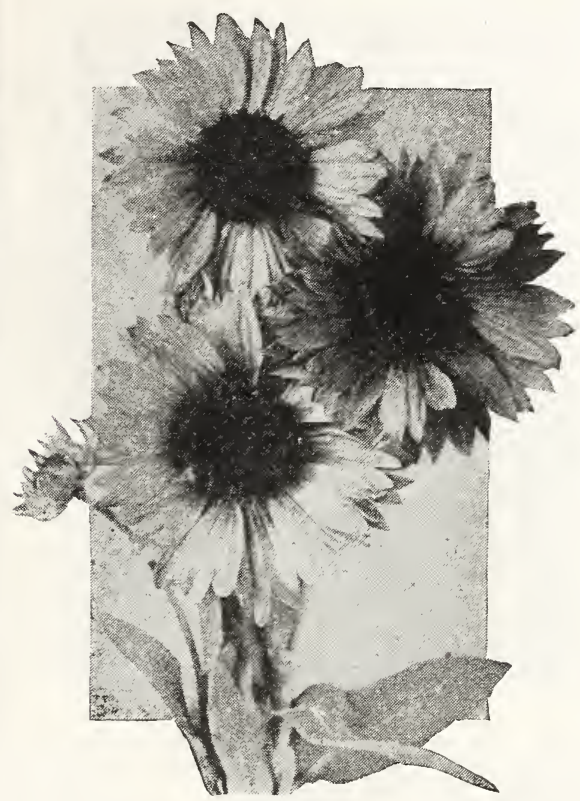

Gaillardia

\section{GAILLARDIA}

(Blanket Flower)

From early Summer until frost these splendid bedding plants produce a profusion of barbaric colored flowers; rich shades of red and yellow. Grown in masses they are especially effective, unrivaled for cutting. 1 to $1 \frac{1 / 2}{2}$ $\mathrm{ft}$.

\section{ANNUAL VARIETIES}

4087 Picta, Single Mixed. 1/4 oz., 25c......Pkt., 10c 4098 Picta, Lorenziana. Large, handsome heads of double quilled flowers in rich shades of red and yellow. $1 / 4$ oz., 25c...............Pkt., 10c

\section{HARDY PERENNIAL VARIETIES}

Their long-flowering period, long stems and bright colors make these one of the most valuable perennials. 4109 Grandiflora Compacta. A compact variety bear ing its varied colored flowers well above the foliage. $1 / 4$ oz., 40c..............Pkt., 10c 4110 Grandifora Superba, Mixed. 2 ft. ....Pkt., 10c

\section{GERANIUM}

Very interesting to grow from seed, they bloom the first year. Start indoors and transplant to the open in May or June.

4121 Zonale, Mixed. A superb strain of the largest and finest varieties................. Pkt., 10c

\section{GEUM}

Very attractive border or rockery plant valued for the bright red flowers. Perennial, easily grown from seed, blooming the first year if sown early.

4133 Atrosanguineum, Fl. Pl. Showy double, dark crimson flowers, blooms all Summer. $11 / 2 \mathrm{ft}$. $1 / 4$ oz., 50c......................... 10c

4134 Mrs. Bradshaw. Very large, double, brilliant orange-scarlet flowers. $11 / 2 \mathrm{ft}$. .......Pkt., 15c

\section{GILIA}

Graceful annuals that bloom most freely and con. tinuously the whole season. $1 \mathrm{ft}$. Sow the seed where it is to grow.

4136 Capitata, Rich lavender-blue flowers. $2 \mathrm{ft}$. tall. Capitata, Rich lavender-blue flowers. 2 ft. tall. Tricolor, Dwarf Mixed. Lavender and white flowers, $1 / 4$ oz., 25c................Pkt., 10c

\section{GLOBE AMARANTH}

(Gomphrena)

A showy annual everlasting with clover-like heads of rich crimson colored flowers, also called "Bachelor's Button." $2 \mathrm{ft}$.

4154 Mixed, all colors. 1/4 oz., 25c.........Pkt., 10c

\section{GLOXINIA}

Magnificent house or greenhouse plants for Summer. Heat and shade are required to get the best results. Seed sown in February will bloom the first Summer. Tender perennial. 6 in.

4165 Hybrids, Mixed ..................... 25k

\section{GODETIA}

Very showy annuals with 2 to 4 -in brilliant pink or red-purple flowers with a satiny lustre. Easily grown; even in poor soils they bloom profusely. July till frost. $1 \mathrm{ft}$.

4176 Fine Mixed. 1/4 oz., 25c.............

GOLDEN FEATHER. See Pyrethrum.

\section{GOURD}

(Ornamental)

A tender, rapid-growing, interesting plant, with striking foliage and singular fruit.

4187 Calabash or Pipe........................ 5 4198 Dipper ............................ 5c

4209 Hercules Club ........................ 5kt.,

4210 White Nest Egg.........................., 5c

4221 Sugar Trough ...................... 5kt.

4232 Luffa or Dish Cloth.................... 5kt., Any of the above, oz., 25c.

4243 Collection. Packet each of above..........25c 4254 Mixed. All varieties. Oz., 25c........Pkt., 5c

\section{GYPSOPHILA}

(Baby's Breath)

Big, gracefully airy heads of small white flowers used by florists and others making up bouquets; "fuzzy stuff" they call it. It is the chiffon of the flower garden. $1 \frac{1}{2}$ to $2 \mathrm{ft}$.

4265 Elegans Alba Grandiflora. An improved form of the annual Baby's Breath. Pure white, large flowers. Oz., 25c .................... 10c 4266 Elegans Grandiflora Rosea. Large rose-colored flowers. Oz. 30c............... Pkt., 10c

4276 Paniculata. White flowers, fine for bouquets; hardy perennials. Blooms first year if sown early. $1 / 4$ oz., 25c........................ 10

4287 Paniculata, Fl. Pl. The double flowering Baby's Breath, forming pretty little double white flow. ers. Perennial ........................ 25c

\section{HELIANTHUS}

\section{(Sunflower)}

Remarkable for its stately growth and decorative effect, suitable for shrubberies, woodlands and wild gardens, the dwarf varieties with small flowers are charming when grouped in mixed flower gardens.

\section{SINGLE ANNUAL VARIETIES}

4310 Miniature Mixed. (Cut and Come Again.) Plants of bush habit producing a continuous succession of flowers from June to frost. The colors are golden yellow, pale yellow and cream white, with dark centers, all beautiful and splen. did for cutting. $3 \mathrm{ft}$. $1 / 4$ oz., $20 \mathrm{c}$.... Pkt., $5 \mathrm{c}$

4343 Russian Mammoth. Gigantic single yellow flow. ers. They will make splendid shade and provide good feed for poultry. $6 \mathrm{ft}$. Oz.......5c

DOUBLE ANNUAL VARIETIES

4365 Chrysanthemum-flowered. Rich golden yellow flowers perfectly double, resembling a Chrysan. themum. $6 \mathrm{ft}$. Oz., 30c............Pkt., 5c 4376 Nanus, F1. PI. (Globe of Gold.) Double dwarf yellow flowers beautiful for massing in beds. 3 ft. Oz., 25c....................... 5c

HARDY SUNFLOWER. Producing a grand effect when planted in garden beds or borders, or in wood. lands or wild gardens.

4387 Mixed ............................, 10c 


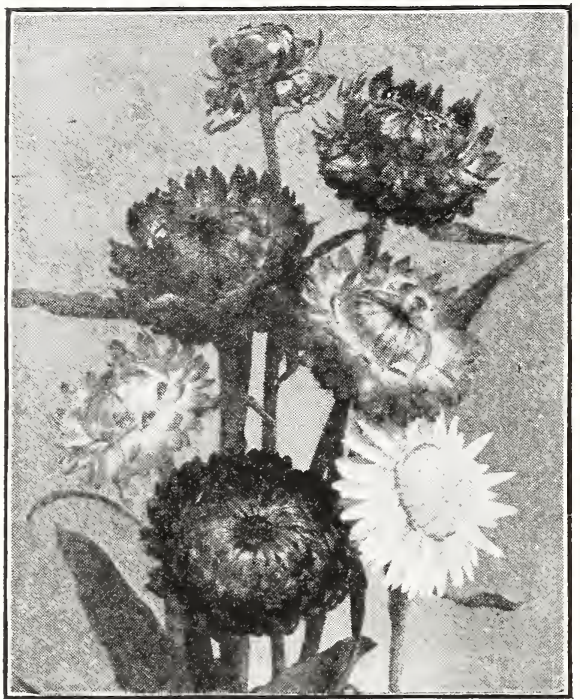

Helichrysum (Straw Flower)

\section{HELICHRYSUM}

(Straw Flower)

Exceedingly effective everlastings; fine for borders. The flowers are large and the color bright; highly prized for Winter bouquets. Flowers intended for drying should be gathered when partially unfolded. Take off all foliage, tie in bunches and hang head down. wards in some dark, dry place until cured. Give them plenty of room to develop, planting not closer than 12 inches apart; hardy annuals. $21 / 2$ feet.

4398 Fireball. Bright red.................. 10k

4409 Silverball ............................. 10k

4410 Goldenball. Golden yellow.............Pkt., 10c

4421 Rose Queen ................................ 10c

4432 Salmon Queen ...................... 10c

4443 Violet Queen ......................... 10c

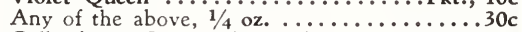

4454 Collection. One packet each............50c

4465 Mixed. All colors. 1/4 oz., 25c......Pkt., 10c

\section{HELIANTHEMUM}

\section{(Rock or Sun Rose)}

4299 Mutabile. An excellent rockery plant. 1 foot Loose, yellow racemes of 1 in. flowers. White to purple. Perennial...............Pkt., 10c

\section{HELIOTROPE}

An extremely popular bedding plant which is easily grown from seed. Seed started indoors in the Spring make fine plants for Summer blooming. Can also be sown outdoors in May. Half-hardy perennial. $11 / 2 \mathrm{ft}$.

4476 Lemoine's Giant. Flowers of great size and varying in color from dark blue to lilac.

$1 / 8$ oz., 40 c......................... 15k 4487 Fine Mixed. 1/8 oz., 30c..............., 10c

4488 Regal Mixed. New type having immense flower heads; all shades ..................... 25 c HESPERIS. See Sweet Rocket.

\section{HIBISCUS}

\section{(Marshmallow)}

Showy ornamental perennial plants, for mixed beds or shrubbery borders, with large and beautifully colored flowers. 4 to 5 feet.

4499 Light Pink .......................... 10c

4501 Dark Red ......................... 10c

4503 Pure White ........................... 10c

4505 Collection. One packet each...............25c

4507 Mixed. 1/4 oz., 25c................. 10kt., 10c

maroon center ........................ 15c

\section{HOLLYHOCK}

\section{(Althæa Rosea)}

A garden without Hollyhocks is not complete. These stately, dignified plants produce wonderful spikes of varied colored flowers. Sow seed in June or July to flower next year, and in the Autumn transplant to permanent position two feet apart each way. Hardy perennial. 6 feet.

4532 Double White ...................... 10c

4543 Double Pink ................................ 10

4554 Double Salmon Rose..................... 10c

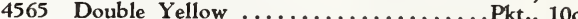

4576 Double Maroon ............................. 10c

4587 Double Red .................................. 10c

Any of the above, $1 / 4$ oz. ............40c

4588 Collection. One packet each...............

4598 Double Mixed. $1 / 4$ oz., $40 \mathrm{c} . . . \ldots \ldots$. Pkt., 10c

4604 Single Mixed. 1/4 oz., 30c........... Pkt., 10c

4609 Allegheny Fringed. The flowers are either double or semi-double, the petals beautifully fringed. All shades and colors are represented. $1 / 4$ oz., 40 c........................... $10 \mathrm{c}$

\section{HONESTY}

(Moonwort, Satin Flower)

Very attractive, hardy biennial. A great favorite because of its curious 2-in. long, broad, very flat pods so thin the seeds can be easily seen. 3 feet.

4610 Mixed. $1 / 4$ oz., $30 c . . . \ldots . . . . . .$. . Pkt., $10 c$

\section{HUMULUS}

\section{(Japanese Hop)}

A very rapid growing vine for covering verandas, porches or stone walls; plants are resistant to heat and drought. Perennial. 10 feet.

4621 Japonicus. Green foliage................, 10c 4622 Variegatus. Foliage variegated, splashed and streaked with white. $1 / 4 \mathrm{oz} ., 25 \mathrm{c} . . .$. .Pkt., $10 \mathrm{c}$

\section{HUNNEMANNIA}

(Bush Eschscholtzia)

Bright clear yellow poppy-like flowers for cutting, that last several days in water. Sow seed in May, bloom July until frost. Annual. 9 in.

4632 Fumariæfolia. $1 / 4 \mathrm{oz} ., 25 \mathrm{c} . . . \ldots \ldots . .$. . Pkt., $10 \mathrm{c}$

HYACINTH BEANS. See Dolichos.

\section{IBERIS}

\section{(Hardy Candytuft)}

Dwarf evergreen plants, covered with blooms in Spring and early Summer. Thrives in shade or sun. Excellent for rockeries or borders. $1 \mathrm{ft}$.

4643 Sempervirens. Pure white............Pkt., 20c 4644 Gibraltarica Hybrida. Large, delicate lilac flowers, May and June.............Pkt., 10c

ICE PLANT. See Mesembryanthemum.

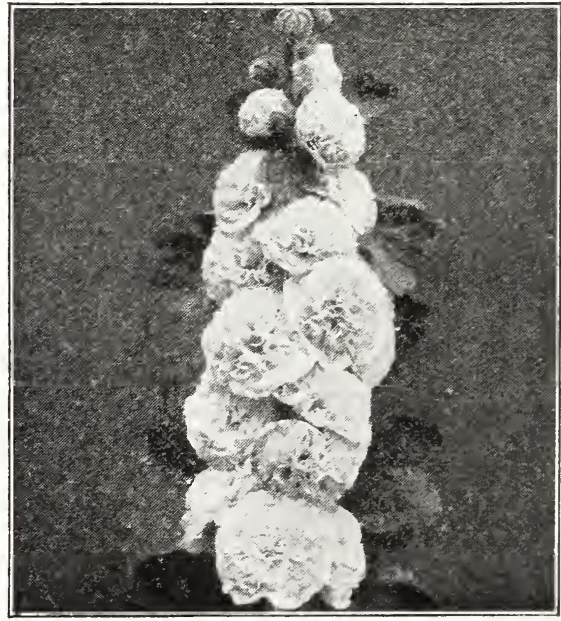

Hollyhock 


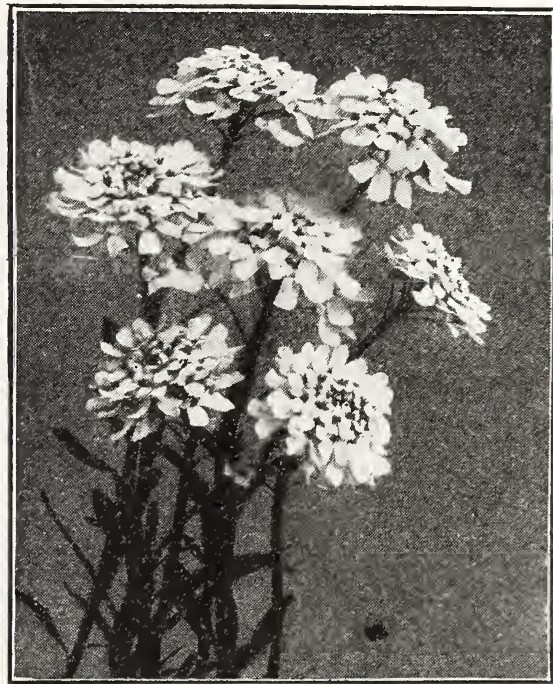

Iberis

\section{IMPATIENS}

(Sultan's Balsam)

Excellent pot plants for house and greenhouse, re. markable for its long duration of bloom.

4654 Sultani. Rose pink flowers, 9 in. ......Pkt., 15 c 4665 Holstii Hybrids. All colors, 18 in. ..Pkt., 15c

\section{IPOMOEA}

Unsurpassed for covering porches and trellises be, cause of their dense, rapid growth. To gain time, sow seeds indoors in heat, transplanting outdoors when danger of frost is past. Soak seeds overnight in warm water to hasten germination. Tender annuals blooming mid.July to frost.

4676 Moonflower (Grandiflora Alba). At night and during dull days the plants are covered with an abundance of large, pure white, fragrant flowers, 5 to 6 inches in diameter. It grows rapidly. The seeds should be notched with a file before soaking. $15 \mathrm{ft}$.

$1 / 2$ oz., 30c....................... 10 ckt.

4698 Rubra Coerulea (Heavenly Blue). Bright sky blue; very beautiful..................... 10c

4709 Setosa (Brazilian Morning Glory) Flowers of a rose color. As a quick-growing vine it has no equal, covering an enormous space in a short

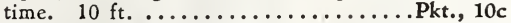

MORNING GLORY (Imperial Japanese). The flowers of this charming variety are of gigantic size and exquisite diversity of colors; often three inches or more across; some are brilliant red or rich blue, others are equally brilliant, with broad margins of clear white; some are striped or dotted with blue or red on white or lemon yellow ground, others are clouded with blue and red. 8 to $10 \mathrm{ft}$.

4743 Imperial Japanese Mixed. Oz., 25c....Pkt., 5c

JAPANESE HOP. See Humulus.

KENILWORTH IVY. See Linaria.

\section{KOCHIA}

(Mexican Fire Bush or Summer Cypress)

A charming and most effective decorative plant, with a habit much resembling one of the compact evergreen shrubs. It has a light grass-green feathery foliage, which changes as the Summer advances to a rich crim. son. Annual. $2 \mathrm{ft}$.

4754 Trichophylla. $1 / 4$ oz., 15c..........Pkt., 10c

\section{KUDZU VINE}

\section{(Pueraria Thunbergiana)}

A vine of remarkably rapid growth, 8 to $10 \mathrm{ft}$. the first year from seed and 40 to $50 \mathrm{ft}$. from estab lished roots. Quickly covers porches, trellises and unsightly objects. Hardy perennial, the tops killing back to the ground each Winter.

4765 Japanese Kudzu Vine. 1/4 oz., 20c....Pkt., 10c

LADY SLIPPER. See Balsam.

\section{LANTANA}

An exquisite bedding plant. Attractive foliage and a wealth of verbena-like flowers all Summer. Orange, white, rose. 2 to $3 \mathrm{ft}$.

4776 Mixed Colors ......................, 10c

\section{LARKSPUR}

(Annual)

The Larkspur is one of the brightest and showiest garden flowers. Plant breeders have produced a wonderful improvement by careful selection in size and color of the flower and the general habit of the plant. The flower spikes are of varied shades of red, blue, white, pink, etc. Splendid for beds or borders. Their graceful habit and bright colors make them very attrac. tive. They are of easy culture, thriving in any soil and give a continuous succession of blooms until cut down by frost. Seed sown in the open ground in April will produce flowering plants by July. $2 \frac{1}{2} \mathrm{ft}$.

\section{TALL DOUBLE STOCK FLOWERED}

4787 Bright Rose ................... Pkt, $10 c$

4788 Dark Blue ........................ 10

4789 Exquisite Pink ....................... 10c

4790 Flesh Color ......................, 10 c

4791 Light Blue ............................ 10

4792 Lustrous Carmine ..................., 10c

4793 White ...................................

Any of the above, $1 / 4 \mathrm{oz} . \ldots \ldots \ldots \ldots . . . .30 \mathrm{c}$

4794 Collection. A packet each..............60

4795 Buist's Finest Mixed. All the colors.

$1 / 4$ oz., $25 c \ldots \ldots \ldots \ldots \ldots \ldots \ldots \ldots$............. 10c

4799 Emperor Mixed. Produces an abundance of the most delicate colors. $2 \mathrm{ft} .1 / 8$ oz., 30c; Pkt., 15c

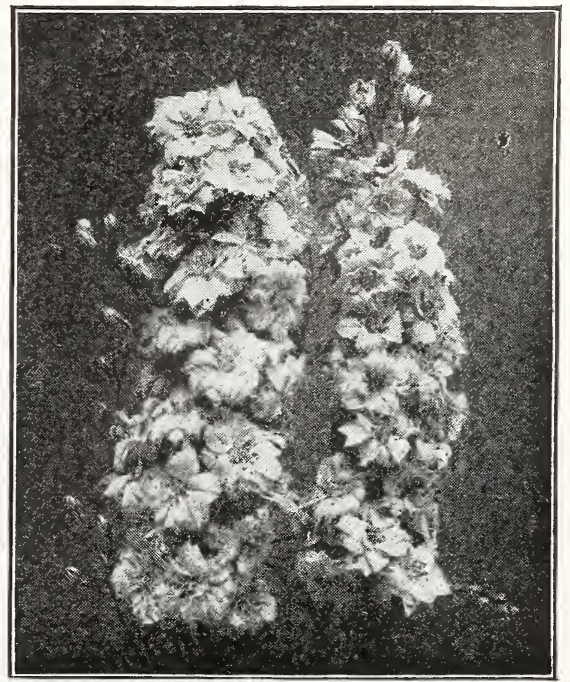

Tall Double Larkspur 


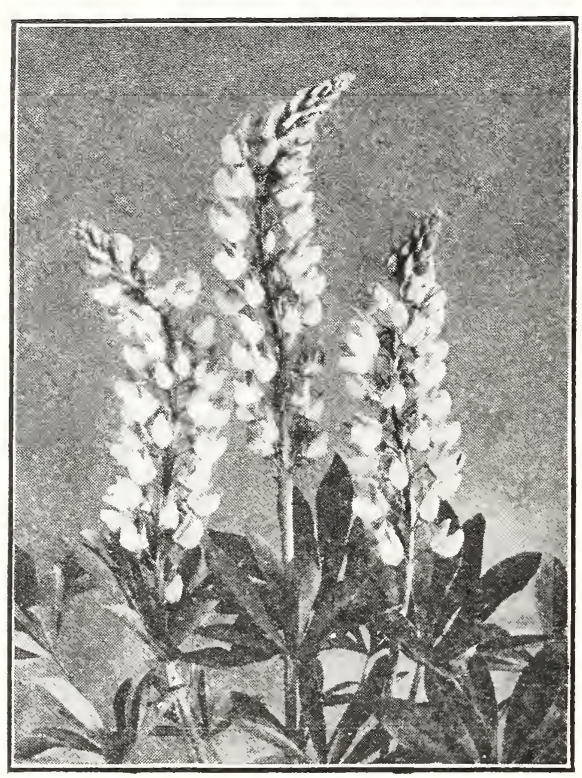

Lupinus

\section{LATHYRUS}

(Everlasting Sweet Peas)

Dense growing, hardy perennial climber for covering fences, stones and rough ground, but few weeds will grow up through them. Blooming from June to frost. 6 to $8 \mathrm{ft}$.

4909 White ............................ 10 c

4910 Pink Beauty ............................... 10c

4921 Mixed. $1 / 4$ oz., 25c; $1 / 2$ oz., $40 c . .$. .Pkt., 10c

\section{LINARIA}

Tender perennial, trailing vine with round dark green leaves; used for rockeries or window boxes.

4812 Cymbalaria (Kenilworth Ivy). Lavender and purple; flowers all Summer............Pkt., 10c

\section{LINUM}

\section{(Flax)}

4813 Grandiflorum Rubrum (Scarlet Flax). An exceedingly effective border or bedding plant with bright red flowers. July to frost. Hardy an. nual. $1 \mathrm{ft}$. Oz., 30c................

4814 Perenne. Bright blue flowers, perennial $11 \frac{1}{2} \mathrm{ft}$. $1 / 4$ oz., 25c........................ 10c

\section{LOBELIA}

Blooming quickly from seed and lasting all Summer, these attractive little bushy plants are exceedingly useful as edgings or for rockeries.

4821 Speciosa. True dark blue, dark foliage, trailing. $1 / 2 \mathrm{ft} . \ldots \ldots \ldots \ldots \ldots \ldots \ldots \ldots \ldots$. . . . . 4832 Crystal Palace Compacta. Beautiful deep blue, 4843 Gracilis. Light blue flowers; slender habit, suit. able for baskets. $1 / 2 \mathrm{ft}$. .............Pkt., 10c 4854 White Gem. Forms a perfect ball of snow. white flowers. $1 / 2 \mathrm{ft} . \ldots \ldots \ldots \ldots \ldots$.......... 10 4865 Mixed Bedding. $1 / 8$ oz., $30 \mathrm{c}$............. Pkt., 10c

\section{LYCHNIS}

Handsome perennial that blooms the first year if sown early. Use for bedding and borders.

4932 Chalcedonica. Scarlet. $2 \mathrm{ft}$. ..........Pkt., 10c

4943 Haageana. Mixed colors. 1 ft. ............., 10c

\section{LUPINUS (Lupine)}

ANNUAL SORTS. Showy spikes of pearshaped flowers, useful in borders and cut flowers. Thrive best in partial shade. $2 \mathrm{ft}$.

4880 Rich Blue ......................... 10c

4881 Sky Blue ................................ 10

4882 Rose ............................, 10c

4883 White $\ldots \ldots \ldots \ldots \ldots \ldots \ldots \ldots \ldots$. Pkt., $10 c$

Any of the above, oz.................40c

4887 Mixed. Oz., 25c...................... 5ct.

PERENNIAL SORTS.

4898 Polyphyllus, Mixed. $3 \mathrm{ft}$. Oz., 25c...Pkt., 10́c

MALLOW. See Hibiscus.

\section{MARIGOLD}

No annual exceeds the Marigold in wealth of bloom. From Mid-Summer on, the big orange or yellow blooms are produced in great abundance on long, stiff stems. They furnish a wealth of color, keeping the garden bright until late in the Fall. They succeed best in a sunny situation.

\section{DOUBLE AFRICAN VARIETIES}

4998 Orange Prince. Densely double of a golden. orange color. $3 \mathrm{ft}, 1 / 4 \mathrm{oz}_{.}, 30 \mathrm{c} . . . .$. . Pkt., $10 \mathrm{c}$

4976 Lemon Queen. Densely double,, color soft lemon yellow. $3 \mathrm{ft}$. $1 / 4 \mathrm{oz} ., 30 \mathrm{c} . . . . . .$. ..Pkt., 10c

4987 El Dorado. Tlowers of immense size in all shades of yellow. $3 \mathrm{ft}$. $1 / 4$ oz., 25c...Pkt., 10c 4965 Dwarf Orange. $11 \frac{1}{2} \mathrm{ft} .1 / 4$ oz., 30c..Pkt., 10c 4966 Dwarf Lemon. $1 \frac{1}{2} \mathrm{ft}$. $1 / 4$ oz., 30c..Pkt., 10c

5009 Double African Mixed. $3 \mathrm{ft}$.

$1 / 4$ oz., 20c......................... $5 c$ DWARF DOUBLE, FRENCH VARIETIES

Extremely attractive bedding plants. 12 in.

5010 Golden Ball (New). Dwarf and compact; fine golden yellow ...................Pkt., 10c

5021 Gold Striped. Very double; brownish red, striped golden yellow..................... 10c

5043 Dwarf French Double Mixed. Brown and golden yellow. $1 / 4$ oz., $20 c . . . . . .$. . Pkt., $5 \mathrm{c}$ SINGLE VARIETIES

5044 Legion of Honor (Little Brownic). Single golden yellow flowers, velvety crimson spots. 9 in. $1 / 4$ oz., 25c...................Pkt., 5c

7609 Signata Pumila. A miniature Marigold forming compact bushy plants 6 to 8 inches high, densely covered with single golden yellow flowers. Fine for borders. $1 / 4$ oz., 40c............. Pkt., $10 \mathrm{c}$

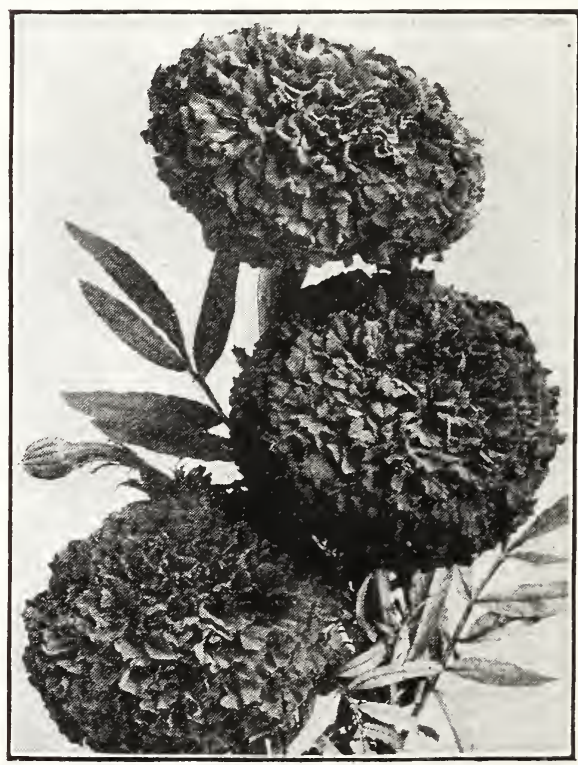

African Marigolds 


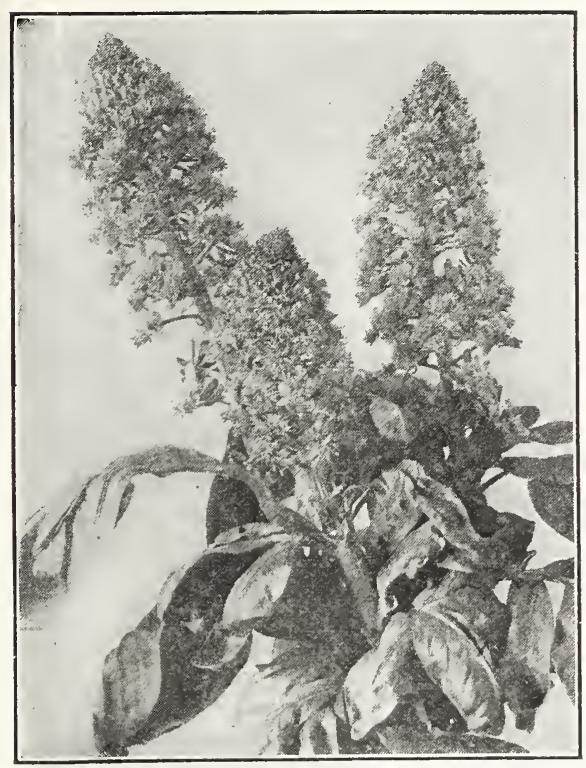

Mignonette

\section{MARVEL OF PERU OR FOUR O'CLOCK}

(Mirabilis Jalapa)

A very popular and most interesting garden plant, growing to a height of $21 / 2$ feet and spreading to perfect tree-shaped bushes $11 / 2$ feet through, which are literally covered with bright-colored blossoms. The flowers open about 4 o'clock in the afternoon, remaining open all night and usually are closed before noon the next day. They range in color from white, to yellow, pink, orange and red. Seeds may be sown in the open garden.

4954 Fine Mixed. Oz., 20c................. 5 c

\section{MAURANDIA}

Very fast growing, halfhardy perennial climber which, if treated like tender annuals, bloom the first year. Fine for trellises and porches. $10 \mathrm{ft}$.

5065 Barclayana. Mixed colors............... 10kt., 10

\section{MESEMBRYANTHEMUM}

An unusually interesting annual with grayish-green leaves with dots that look like dew. Grows outdoors in dry sunny places. Fine for pots, rockwork and hanging baskets indoors. 6 in.

5076 Crystallinum (Ice Plant). White.......Pkt., 5c

\section{MIGNONETTE}

\section{(Reseda)}

The sweet delicate fragrance makes this a favorite in ev-ry garden. Sowings made in April and again in July will keep up a succession from early Summer until frost; can also be grown in pots for Winter and early Spring flowering. Hardy annual. 6 to 8 in.

5087 Red Goliath. Foliage rich green with giant spikes of red flowers. 1/8 oz., 25c.....Pkt., 10c

5098 Machet. Large spikes reddish-tinted, one of the best for either garden or pot culture.

1 .

5099 Golden Queen. Yellow tinted flowers.

$1 / 4$ oz., 25 c.......................... $10 \mathrm{c}$

5109 White Goliath. Giant spikes, pure white, very fragrant. $1 / 4$ oz., 25c...............Pkt., 10c

5132 Sweet Scented (Reseda Odorata). The popular garden sort. Oz., 20c................ Pkt., 5c

\section{MIMOSA}

(Sensitive Plant)

Called Sensitive Plant because at the slightest touch the leaves fold upward and droop. This peculiarity makes it a novelty worth growing. 18 in.

5143 Pudica .............................. 10 c

\section{MIMULUS}

Very showy flowers, big in proportion to the size of the plants. Fine for beds, edging beds or pot plants indoors. Half-hardy perennials; bloom first year from seed if started indoors early.

5154 Tigrinus (Monkey Flowers). Fine mixed spotted

varieties. $1 \mathrm{ft} . \ldots \ldots \ldots \ldots \ldots \ldots \ldots . . . . . . . .10 \mathrm{c}$

5165 Moschatus (Musk Plant). Fine for hanging baskets, vases, etc., with a profusion of small yellow flowers. 6 in. ................. 15 c

\section{MOMORDICA}

5176 Balsam Apple (Balsamina). A climbing, half hardy annual, bearing yellow flowers and orna. mental fruit of medicinal value.

$1 / 2$ oz., 25c.......................

5187 Balsam Pear (Charantia). Like above, only the fruit is pearshaped.................... 10 c

MONKSHOOD. See Aconitum.

MOONFLOWER. See Ipomœa.

MORNING GLORY. See I pomøa.

MOURNING BRIDE. See Scabiosa.

\section{MYOSOTIS}

\section{(Forget-Me-Not)}

Dainty, sweetly-scented, little flowers that appeal to everybody. A few plants impart a delicious odor to the house, garden or greenhouse. Seed may be sown any time from Spring until Mid-Summer. Half-hardy perennial. 8 in.

5188 Alpestris, Royal Blue. Indigo blue. The best dark blue. 9 in. $1 / 4$ oz., 40 c.......... Pkt., $10 \mathrm{c}$

5198 Alpestris, Mixed. 1/4 oz., 30c..........Pkt., 10c 5209 Palustris. True Forget-Me-Not. Bright blue flowers with a yellow eye...............

5210 Palustris Semperflorens. An ever.blooming dwarf form of the above..............Pkt., 15c

\section{NICOTIANA}

\section{(Tobacco Plant)}

Tall spikes, with many long,tubular flowers giving off sweet fragrance at night, blooming continually. $3 \mathrm{ft}$.

5543 Affinis. Pure white. 1/4 oz., 25c.....Pkt., 10c 5554 Sanderæ Hybrids. Flowers fragrant in a great variety of colors. $1 / 4$ oz., 25 c........Pkt., $10 \mathrm{c}$

\section{NIGELLA}

\section{(Love-in-a-Mist)}

Delightful little airy plants with needle.like foliage and curious looking flowers and seed pods. Thrives in any soil. Hardy annual. $1 \mathrm{ft}$.

5565 Miss Jekyll. A lovely variety with cornflower blue blossoms A.................Pkt., 10c 5576 Damascena. Blue and white mixed....Pkt., 10c

\section{OENOTHERA}

\section{(Evening Primrose)}

A beautiful low.growing annual; the bright poppy. like flowers open on approach of twilight and last well into the next day. $1 \mathrm{ft}$.

5587 Mixed ......................... 10 c

FLOWER SEEDS BY WEIGHT

We carry large stocks of all Flower Seeds and shall be pleased to quote larger amounts of the varieties we list upon application. 


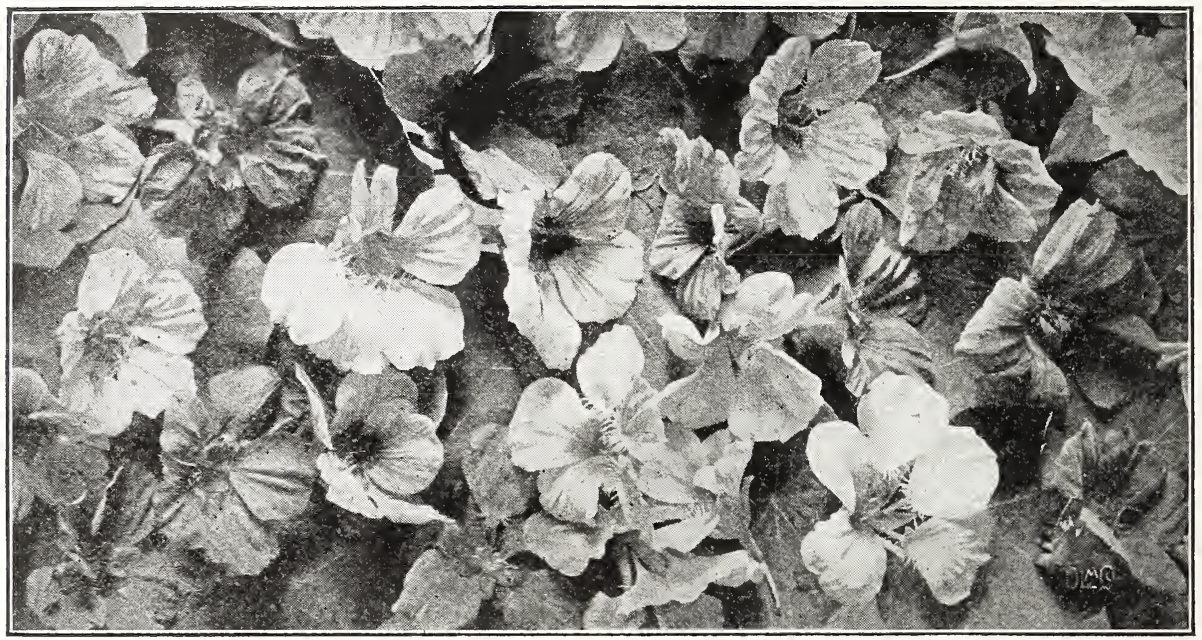

\section{Buist's Giant Flowering Nasturtiums}

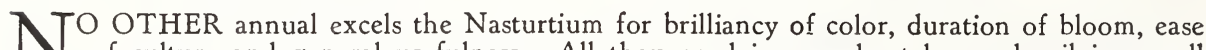
1 of culture and general usefulness. All they need is a moderately good soil in a well drained, sunny situation, and within a few weeks from the time they are planted until frost comes, there is an endless profusion of their gorgeous blossoms. They are suitable for bedding and edging; grow quickly and will thrive best in light or sandy soils. Plant seed when ground is warm, 2 inches deep and thin to stand 6 inches. The more the flowers are picked, the more freely they will bloom.

\section{DWARF OR BEDDING VARIETIES}

5221 Beauty. Scarlet, splashed canary.

5232 Bronze. Burnt bronze color, dark leaves.

5243 Chameleon. Crimson, bronze and yellow.

5254 Crystal Palace Gem. Sulphur yellow spotted carmine.

5265 Empress of India. Crimson, dark foliage.

5276 Golden King. Golden yellow, dark foliage.

5287 Golden Cloth. Golden yellow leaves, scarlet flowers.

5298 King of Tom Thumbs. Brightest scarlet, dark foliage.

5309 King Theodore. Dark maroon; dark foliage.

5310 Lady Bird. Orange, spotted bright scarlet.

5321 Pearl. Creamy white.

5332 Prince Henry. Yellow, spotted scarlet.

5343 Rose. A lovely shade of ruby rose.

5354 Ruby King. Rich red, dark foliage.

5365 Vesuvius. Salmon-rose.

Price. Any of the above dwarf varieties. $20 \mathrm{c}$ per oz.; $60 \mathrm{c}$ per $1 / 4 \mathrm{lb}$............

Collection. One pkt. each of the above 15

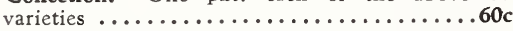

Buist's Special Mixture of Dwarf Giant Flowered. A matchless mixture of the Dwarf Giant varieties. It is composed of the most elegant large flowered sorts, the colors range through every tint and shade. Their fine color, long stems, great size make them valuable for cutting. $1 / 2$ oz., 10c; oz., 20c; $1 / 4$ lb., 60c.......Pkt., 5c

5398 Fine Mixed Dwarf. A mixture of the leading dwarf varieties. Oz.s 15c; $1 / 4$ lb., 50c..Pkt., 5c

\section{TALL OR CLIMBING VARIETIES}

Elegant and luxuriant climbers for verandas, trellises, etc., and particularly suitable for vases, hanging baskets, window boxes and rockeries, when a drooping effect is wanted.

5409 Butterfly. Lemon yellow with blotch of deep red on lower petal.

5410 Chameleon. Flowers of quite distinct coloring on one and the same plant.

5421 King Theodore. Deep crimson maroon.

5432 Midnight. Deep brownish red.

5443 Moonlight. Creamy yellow flowers.

5454 Rose. Soft rose color.

5465 Schulzi. Rich deep scarlet.

5476 Sunlight. Rich golden yellow.

5487 Twilight. Light salmon, suffused with rosy salmon.

5498 Vesuvius. Salmon rose, dark leaf. Price. Any of the above tall varieties. oz., 15c; $1 / 4$ lb., 50c......................... $5 \mathrm{c}$

5509 Collection. One packet each of the above 10 varieties ......................40c

5510 Buist's Special Mixture of Tall Giant Flowered. Contains all the leading varieties of the Tall Giant varieties and the beautiful combination of colors cannot be excelled. $1 / 2$ oz., 10c; oz., 15c; $1 / 4$ lb., 50 c......................... 5 kt.

5521 Tall Mixed. Many desirable shades and colors. Oz., 10c; 1/4 lb., 35c................Pkt., 5c 


\section{BUIST'S GIANT PANSIES}

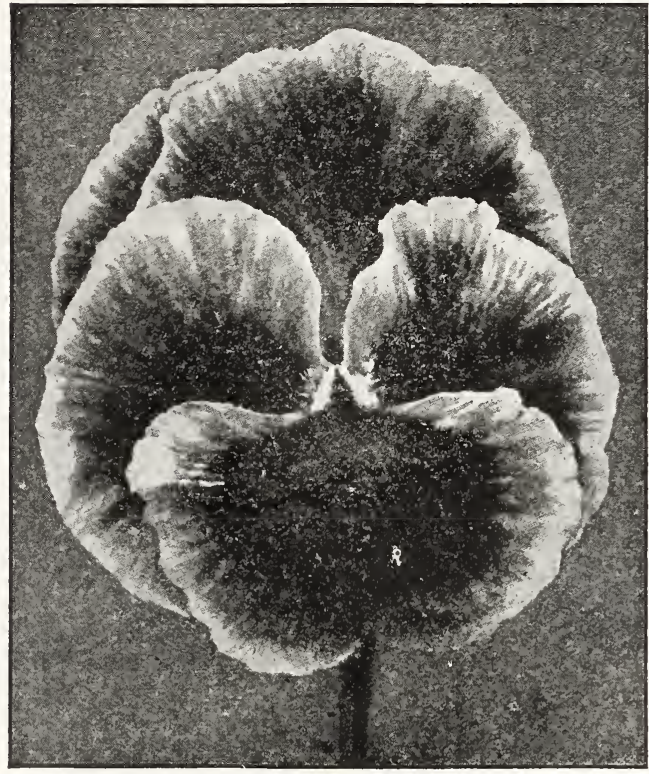

Buist's Prize Pansy

\section{PANSY}

This beautiful flower is too well known to need any description. The seed we offer has been saved from the most distinct and best-named varieties. The higher priced sorts produce the best flowers. Pansies thrive best in a moist, rich, loamy soil. For Summer blooming, sow seed intoors very early and transplant when 2 inches high or sow in the open gromnd the latter part of April. For early Spring blooming, sow seed in August or September and transplant 4 to 5 inches apart into cold frames or they may be wintered over in the open ground with protection of hay or straw. In the early Spring, transplant to their flowering beds to stand 9 inches apart. Well pulverized soil should be used and the seed covered about four times their size and firmly pressed down. During dry weather, the bed should be watered daily. Hardy perennials but usually treated as an annual or biennial.

\section{PANSIES IN MIXTURE}

5598 Buist's Prize Pansy. This strain of Pansy comprises a collection of the most beautiful colors and markings. Each year we add the latest Giants. The Buist Prize is unsurpassed as regards size, texture and colorings. 1/16 oz., $\$ 1.00 ; 5$ pkts., \$1.00..............Pkt., 25c

5609 Bugnot's Superb Blotched. An incomparable strain; extremely large, three blotched flowers, upper petals finely lined. $1 / 8 \mathrm{oz} ., 75 \mathrm{c}$. .Pkt., $20 \mathrm{c}$

5610 Madame Perret. A splendid giant-flowered strain, comprising all shades of red from light rose to dark purple. $1 / 8 \mathrm{oz} ., 60 \mathrm{c} . . .$. ..Pkt., $15 \mathrm{c}$

5615 Buist's Exhibition Giants. A mixture of Giant Pansies unrivaled for diversity of coloring and marking. Blooms of gigantic size in an immense variety of brilliant colors..............Pkt., 50c

5621 Masterpiece (Frilled Pansy). Nearly all the plants produce beautifully ruffled flowers of large size and very fascinating colors.

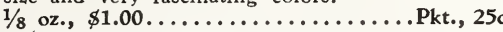

5654 Buist's Superb Mixture. A blend of the finest strains including a large variety of the richest colors. $1 / 8$ oz., $40 \mathrm{c} . . . \ldots \ldots \ldots \ldots .$. . Pkt., 10c

5665

Fine Mixed. All colors. $1 / 4$ oz., 40c;

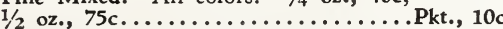

\section{TUFTED PANSIES OR VIOLAS}

A very delightful pansy. The blooms while not as large as pansy flowers, have fair size, delightful violet odor and are freely produced. These tufted Pansies are good bedders and if in a partially shaded place, bloom all Summer. Hardy perennial. 6 in.

5821 Blue Perfection. Deep blue..........Pkt., 10c 5832 White Perfection. Pure white.........Pkt., 10c 5843 Lutea Splendens. Golden yellow......Pkt., 10c 5854 Mixed. All colors. $1 / 8$ oz., 40c......Pkt., 10c

\section{GIANT TRIMARDEAU PANSIES}

Very showy class, of vigorous and compact growth and enormously large flowers; the form and coloring are of the most beautiful type, each flower has three large blotches.

5676 Adonis. Light blue................... $10 c$

5709 Bronze. Golden bronze.................. 10

5721 Cardinal. Brilliant red...................... 10c

5732 Faust (King of the Blacks).................. 10

5724 Golden Queen. Rich yellow..........Pkt., 10c

5743 Lord Beaconsfield. Violet. .............Pkt., 10c

5744 Royal Purple. Deep purple.................... 10c

5745 Snow Queen. Pure white................. 10c

5776 Victoria. Blood-red ..................... 10k

5787 White. With dark eye..................... 10c

5798 Yellow. With dark eye................., 10c

Any of the above, $1 / 8 \mathrm{oz} . \ldots \ldots \ldots \ldots 6 \mathrm{c}$

5809 Collection offer. A packet each of the above 11 named varieties....................85c

5810 Giant Trimardeau Mixed. Large flowers in various colors and shades. $1 / 8 \mathrm{oz} ., 30 \mathrm{c}$;

$1 / 4$ oz., 50c........................... 10 c

\section{PENTSTEMON}

\section{(Beard Tongue)}

Hardy herbaceous plants which produce continuously an abundance of brilliant flowers, somewhat like the foxglove, but mostly with white throats. Makes a fine border flower. 2 to 3 feet.

5860 Grandiflora Mixed .................... 10kt.,

PERIWINKLE. See Vinca.

\section{WILD FLOWER GARDEN}

A mixture of bright colors, free-flowering, easily grown annuals that with little care will produce an abundance of beautiful flowers from early Sum. mer until frost. Oz., 25c; $1 / 4$ lb., 75c; 1b., $\$ 2.50$.

Pkt., 5c 


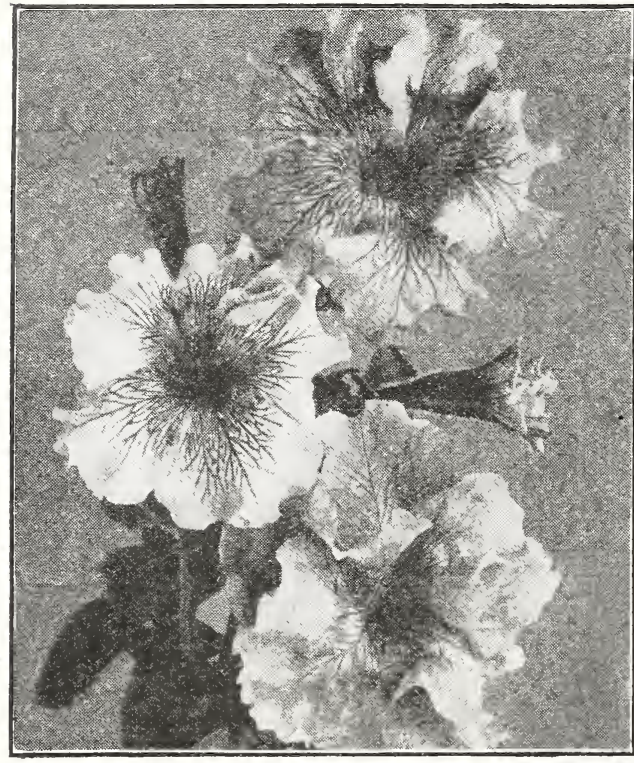

Buist's Giant Petunias

\section{PETUNIAS}

A bed of Petunias is a glorious sight indeed. For freedom of bloom, variety of color and effectiveness they have no equals. They commence to flower early, and if only a little care is bestowed upon them, Petunias will produce their handsome sweet-scented flowers in their delicate and gorgeous colors throughout the entire Summer. 1 to $1 \frac{1}{2} \mathrm{ft}$. The seed is very fine and should be covered lightly.

$\mathrm{Be}$ sure to save the weakest seedlings of the Giant Petunias. These weaklings are the ones which will produce the finest flowers. With a little extra care, they will grow quickly into strong sturdy plants bearing flowers of magnificent size and color.

\section{BUIST'S GIANT PETUNIAS}

5865 Buist's Superb Giant. A strain of incomparable beauty with extremely large deep-throated flowers embracing every conceivable color, shade and markings ........................... 25c

5876 Ruffled Giants. "The edges are deeply ruffled and fluted, of great substance, with deep, wide throats, varying in color from pure white to deep purple .................................. 25c

5887 Giant Double Mixed. A superb mixture of the best large flowering and fringed double Petunias. About 40 per cent will bear double flowers. It is important to save the weaker seedlings as these invariably produce the finest double

flowers ............................... 40c

5889 Purple Prince. A splendid velvety purple, large flowering variety ...................... $25 \mathrm{c}$

GIANT FLOWERING SINGLE FRINGED. The beauty and size of this class make them very desirable. The flowers are ruffled or fringed and measure 4 to 5 inches across.

5962 Pride of Portland. Deep rose .........Pkt., 25c 5901 Romany Lass. Clear bright velvety blood.red with purple throat, striped in black...Pkt., 25c

5964 Scarlet Beauty. Crimson-scarlet, shading to rose in the throat............................ 25c

5899 Triumph. Clear bright pink. The best fringed pink .............................. 25c

5961 White Beauty. Pure white......................... 25c

5966 Collection. Packet each of above......\$1.00

5898 Giant Fringed Mixed. A superb mixture of elegant fringed flowers...............Pkt., 20c

\section{SINGLE BEDDING PETUNIAS}

Free-flowering type, splendid for bedding, window boxes, hanging baskets, etc.

5905 General Dodd's. Rich crimson garnet.

Pkt., 10c

5907 Violacea. Steel blue or deep violet. Pkt., 10c

5908 Rose of Heaven. Rich brilliant rose. Pkt., 10c

5909 Howard's Star. Deep crimson with a dis. tinct white star in center...........Pkt., 10c

5910 Rosy Morn. Brilliant rose with white throat. Very desirable for beds

or borders ...................... 10 ckt.

5921 Snowball. White. ................. 10k Any of the above, $1 / 8$ oz. ...........50c

5932 Collection. Packet each of the above...50c

5943 Striped and Blotched. An excellent strain of the small flowering type, fine for mass ing. All colors. $1 / 4$ oz., 50c......Pkt., 10c

5954 Fine Mixed Single. Good bright colors, small flowers. 1/4 oz., 30c........Pkt., 10c

\section{BALCONY PETUNIAS}

These large and beautiful Petunias were bred to produce a wealth of bloom when grown in porch or window boxes, or garden vases. The blooms are in solid colors; when grown in beds or borders, they produce pleasing, striking effects.

5955 Balcony Blue. Indigo blue.........Pkt., 15c 5956 Balcony Rose. Rose pink..........Pkt., 15c 5957 Balcony White. Snow white...........Pkt., 15c 5958 Balcony Crimson. Velvety crimson...Pkt., 15c 5959 Collection. Packet each of the above.... 50 5960 Mixed Colors. 1/16 oz., 50c.........Pkt., 15c

\section{PHLOX DRUMMONDII}

This splendid genus of plants is unrivaled for rich. ness of color, profusion of bloom, length of duration of bloom and general compactness, and whether in clumps or masses looks equally beautiful. It is the finest annual in cultivation, and should occupy a prominent place in every garden. Seeds should be sown in the open ground any time after danger of frost is over and in a few weeks the beds are a blaze of glory, remaining so until frost.

GRANDIFLORA VARIETIES. This is the finest type, having large heads of bloom as well as large individual flowers. Height, 15 in.

5970 Pure White ........................ 10 c

5976 Shell Pink ................................ 10

5987 Brilliant Rose ....................., 10c

5998 Bright Scarlet ......................., 10c

6009 Rich Crimson ......................... 10

6010 Primrose ............................. 10c

6011 Soft Lilac ........................ 10c

Any of the above, $1 / 4$ oz. ................

6021 Collection. One packet each.............50

6032 Choice Mixed Grandiflora. Superb mixture.

$1 / 4$ oz., 30c; oz., \$1.00............... 10 c

DWARF VARIETIES. Excellent for bedding or edging. Height 8 in.

6054 Chamois. Rose .................... 15k c

6065 Fireball. Scarlet .......................... 15k

6076 Snowball. Pure white........................ 15c

6087 Finest Mixed. 1/4 oz., 50c............ Pkt., 10c

6088 Star-Eyed Mixed. Dwarf habit, beautiful colors, each flower having a white star-like eye.

$1 / 4$ oz., 40 c...................... $10 \mathrm{c}$

\section{HARDY PERENNIAL PHLOX}

An entirely different plant from the annual form, to $3 \mathrm{ft}$. tall, with large dome-shaped heads of large, waxy flowers of lovely shades of colors. Seed slow to germinate.

6098 Mixed Colors.

$1 / 8$ oz., 40c; $1 / 4$ oz., 75c............Pkt., 10c PHYSALIS. See Chinese Lantern Plant.

PINKS. See Dianthus. 


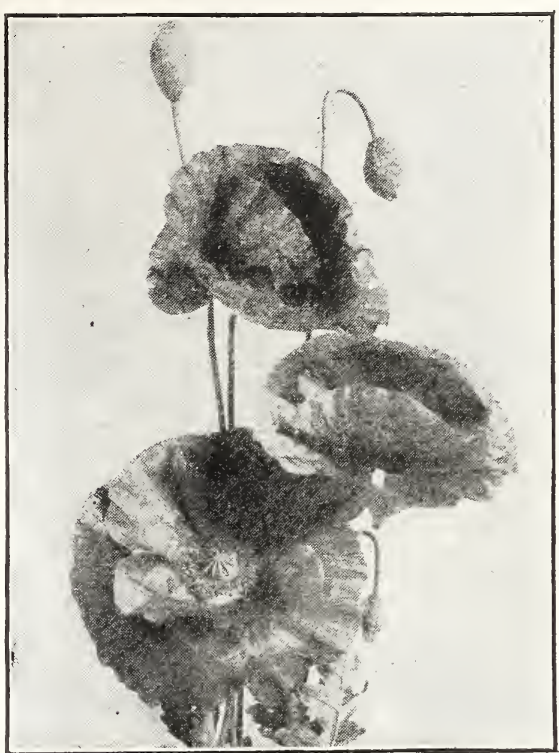

Buist's Shirley Poppy

\section{POPPIES}

A great wealth of color and a wonderful variety of form varying from the large singles to the shredded petal doubles, in many brilliant color combinations. Make the first sowing as soon as the ground can be worked in the Spring, sowing where they are to grow, as they do not transplant easily. If the flowers are gathered early in the morning when the dew is on them, they will remain fresh for several days. $2 \mathrm{ft}$.

\section{SINGLE ANNUAL POPPIES}

6109 Buist's Shirley. No flower is so exceedingly graceful and decorates our garden with such brilliancy of color as this charming Poppy. Our strain is of unusual beauty, the shades of colors are almost endless. 1/4 oz., 25c........Pkt., 10c

6110 American Legion. An improved Flanders Poppy, big, dazzling orange blossoms.

$1 / 4$ oz., 25c............................. 10c

6111 Shirley Wild-Rose Pink. A Shirley Poppy of wild rose-pink color. $1 / 4$ oz., 30c......Pkt., 10c

6113 Dainty Lady. Rosy mauve, dark metallic blotches. $1 / 4$ oz., 20c...............Pkt., $5 c$

6114 King Edward. New. Deep scarlet shaded crimson-red, black spots. $1 / 4$ oz., 20c..Pkt., $5 \mathrm{c}$

6115 The Bride. Pure white. 1/4 oz., 20c..Pkt., 5c

6117 Tulip Poppy (Glaucum). Large tulip-shaped flowers of dazzling scarlet. 1/4 oz., 30c; Pkt., 5c

6121 Danebrog. Brilliant scarlet, with white spot on each petal. $1 \frac{1}{4}$ oz., 20c............... Pkt., $5 \mathrm{c}$

6143 Admiral. Flowers of purest white, with a broad band of brilliant scarlet around the edge.

$1 / 4$ oz., 20c....................... pkt., $5 c$

6165 Collection. One packet each..........50c

6176 Mixed Single. Oz., 25c................ $5 c$

\section{DOUBLE ANNUAL POPPIES}

6185 Double Shirley. The same range of colors as the single Shirley. $1 / 4$ oz., 20c........Pkt., 10c

6187 American Flag. Flowers large, snow white bordered with scarlet. Oz., 30c.........Pkt., 5c
DOUBLE POPPIES-Continued

6189 Shell-Pink. Oz., 30..............Pkt., 5c

6190 Violacea. Beautiful violet tints.

$1 / 4$ oz., 30c.......................... 10c

6198 Fairy Blush. Flowers white, fringed and tipped with rose. Oz., 30c................. 5kt., 5c

6209 Mikado. Large white flowers, attractively fringed with rose. Oz., 30c..........Pkt., 5c

6210 Pæony Flowered. Mixed. Oz., 25c....Pkt., 5c

6221 Cardinal Red. Oz., 30c............Pkt., 5c

6232 Collection. One packet each............35c

6243 Double Mixed. Many kinds and colors.

Oz., 25c .............................. 5c

\section{ICELAND POPPIES}

(Papaver Nudicaule)

Although hardy perennials, these dwarf Poppies bloom the first season from seed sown early in Spring. Plants are of graceful neat habit with fern-like foliage producing their brilliant fragrant flowers in profusion, and if the seed pods are picked off, continue to flower all season. $1 \mathrm{ft}$.

6254 Yellow. $1 / 8$ oz., 30c..............Pkt., 10c

6265 Orange. $1 / 8$ oz., 30c..............Pkt., 10c

6276 White. $1 / 8$ oz., 30c..............Pkt., 10c

6287 Finest Mixed. $1 / 8$ oz., $25 \mathrm{c} . \ldots \ldots \ldots$. Pkt., 10c

\section{ORIENTAL HARDY POPPIES}

Oriental Poppies rival in gorgeous beauty the Darwin Tulips and are one of the showiest, most effective flowers grown; height, 2 to $3 \mathrm{ft}$., flowers immense, often 6 in. across.

6298 Orientale (The Large Oriental Poppy). Bright scarlet with black blotch; very showy.

$1 / 4$ oz., 30c............................. 10c

6309 Mrs. Perry. Orange-apricot...........Pkt., 15c

6310 Princess Victoria Louise. Salmon pink. Pkt., 15c

6332 Rembrandt. Magnificent orange-scarlet, the most gorgeous of all....................... 10 c

6343 Collection. Packet each of the above.....40c

6354 Oriental Mixed Hybrids. These Oriental Pop. pies make a gorgeous display in the garden where the barbaric red of the parent oriental would clash. $1 / 8$ oz., 30c; $1 / 4$ oz., 50c...Pkt., 10c

6355 Alpinum. A delightful little Poppy only 6 in. tall. Brilliant flowers in many shades of colors. Invaluable for rockeries. $1 / 8$ oz., $40 \mathrm{c}$. . Pkt., 15c

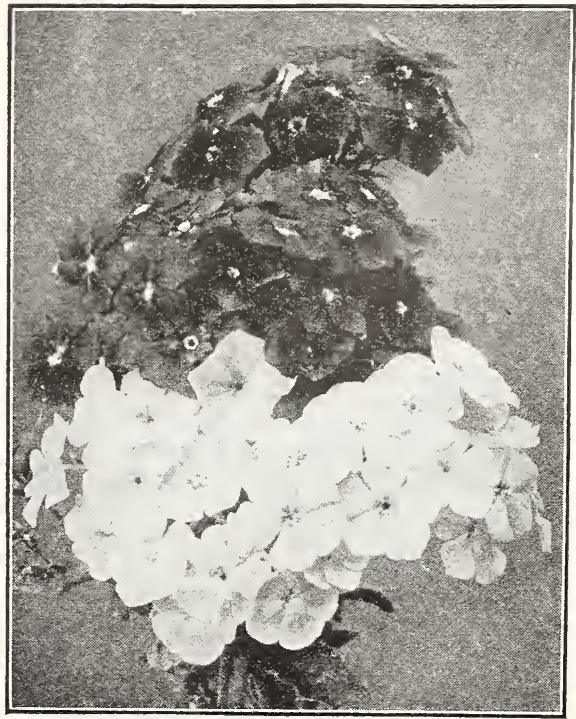

Phlox Drummondii 


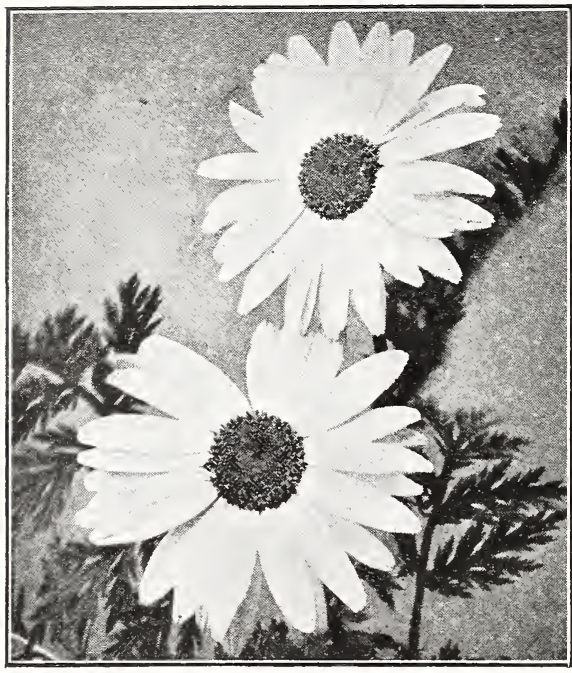

Single Pyrethrum

\section{PORTULACA}

These brilliant and popular hardy annuals are of the easiest culture, luxuriating in an exposed, sunny situa. tion, and producing throughout the Summer their various colored flowers in the greatest profusion. For very dry, sun exposed places, for rockwork, or low bedding at the seashore they are indispensable. 6 in. 6365 Fine Single Mixed. 1/2 oz., 30c........Pkt., 5c 6376 Choicest Double Mixed. Saved from double flowers. $1 / 8$ oz., $40 \mathrm{c} . . . . . . . . .$. . Pkt., 10c

\section{PRIMULA}

\section{(Chinese Primrose)}

A very attractive and indispensable plant for the greenhouse or conservatory, flowering very profusely during the Winter and Spring months. Our seed has been saved from the choicest strains.

6387 Excelsior Fringed Mixed: Contains only the largest fringed flowering sorts..........Pkt., 25c

\section{PRIMULA VERIS (Cowslip)}

This beautiful Spring flowering dwarf hardy perennial bears clusters of fragrant flowers of various colors. 6 in. 6410 Mixed. All colors..................... 10c

PRIMROSE, EVENING. See Oenothera.

PUERARIA THUNBERGIANA. See Kudzu Vine.

\section{PYRETHRUM}

Very showy flowers of easy cultivation; valuable for cutting. The daisy-like blossoms borne in great abund ance and a variety of colors. One of the best hardy perennials. $11 / 2 \mathrm{ft}$.

6421 Single Hybrids. Mixed. 1/4 oz., 75c..Pkt., $10 \mathrm{c}$ 6432 Hybrid Grandiflorum. A very large flowered form of the above..................... 15c 6443 Double Hybrids. Mixed...................... 25c

6454 Aureum (Golden Feather). Fine little plant for bordering and edging beds, contrasting very nicely with its bright yellow foliage. 6 in.

$1 / 4$ oz., 25c......................Pkt., 10c

\section{RHODANTHE}

\section{(Swan River Everlasting)}

An "everlasting" or "straw flower" of delightful :olors. Fine for Winter bouquets. $1 \mathrm{ft}$.

6455 Mixed ............................. 10 c ROSE OF HEAVEN. See Agrostemma.

\section{RICINUS}

\section{(Castor Oil Bean)}

For producing tropical effects about the house and garden, this quick growing annual is unsurpassed. The big, heavy star shaped foliage is luxuriantly produced. Brilliant colored fruits.

6465 Sanguineus (Obermanni). Blood red stalks, scarlet fruits. $8 \mathrm{ft}$. Oz., 25c.........Pkt., 5c

6476 Gibsoni. Dark red leaves and stem. $5 \mathrm{ft}$.

Oz., 25c .......................... 5 c

6487 Borboniensis Arboreus. Handsome foliage and noble growth. $15 \mathrm{ft}$. Oz., 25c.......Pkt., 5c

6498 Cambodgiensis. Large plum-like leaves of the darkest brown maroon, stalk and stem nearly black. $5 \mathrm{ft}$. Oz., 25c.............Pkt., $5 \mathrm{c}$

6509 Zanzibariensis. A distinct class which surpasses all varieties in size and beauty. The orna. mental leaves, beautifully lobed, are $21 / 2 \mathrm{ft}$. across; height, $12 \mathrm{ft}$. Oz., 25c........Pkt., $5 \mathrm{c}$ 6510 Mixed. All sorts. Oz., 20c.............

\section{RUDBECKIA}

\section{(Cone Flower)}

Daisy-like 2-in. flowers borne in great profusion, June to August.

6521 Bicolor Superba. Yellow flower with brown in center; annual. $2 \mathrm{ft}$. .................. 10

6532 Purpurea (Giant Purple Cone Flower). Hardy perennial crimson-purple flowers with dark brown disc. $3 \mathrm{ft} . . . \ldots \ldots \ldots \ldots \ldots$.......... 10c

6533 Newmani. Large yellow flowers with black cen

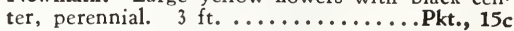

\section{SALPIGLOSSIS}

\section{(Painted Tongue)}

Few flowers grown from seed can compare with the richness and diversity of colors as this half hardy annual, and very few contribute such a wealth of color from Summer until cut down by frost. The beautiful funnel-shaped flowers have either gold or silver veins running through the groundwork of the flower, and their orchid-like appearance attract instant attention. $11 / 2 \mathrm{ft}$.

6543 Crimson ......................... 10c 6544 Primrose ...................................... 10c

6545 Purple and Gold...................... 10c

6546 Rose and Gold........................ 10

6547 Scarlet and Gold.......................... 10c

6548 White and Gold....................., 10c

6549 Collection. A packet of each...........50

6550 Finest Mixed. $1 / 4$ oz., $40 \mathrm{c} . \ldots \ldots \ldots \ldots$........ 10c

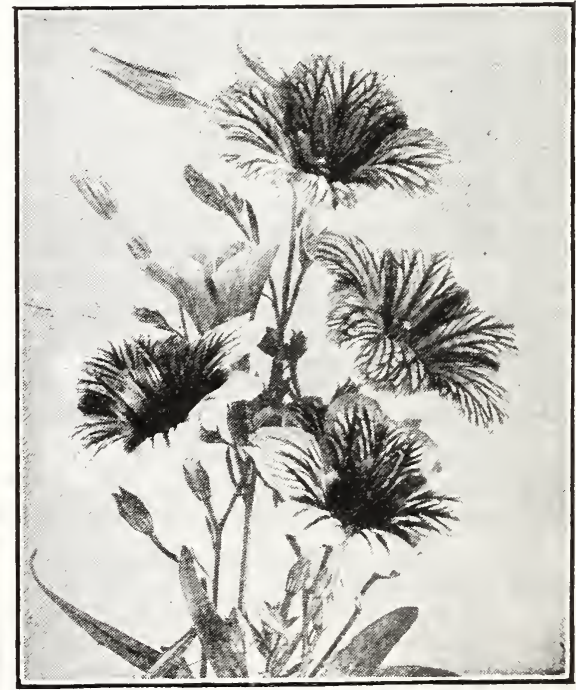

Salpiglossis 


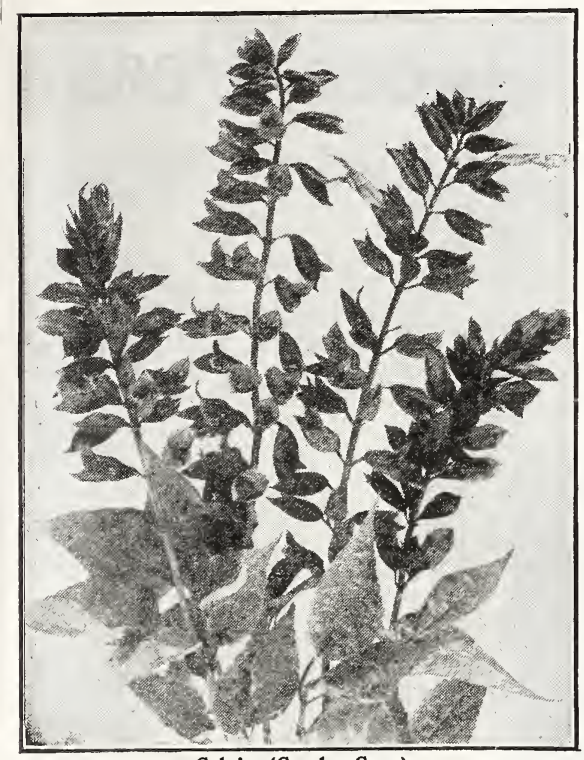

Salvia (Scarlet Sage)

\section{SALVIA}

\section{(Scarlet Sage)}

One of the handsomest flower plants for garden decoration; keeps the garden bright until late in the Fall. Fine bedding plant. Seed should be sown in. doors or in a hotbed and the young plants transferred to the open ground when the weather becomes suitable.

6598 America or Globe of Fire. A free and con. tinuous bloomer, also the most uniform in habit of growth, which makes it particularly valuable for beds or borders; height, $2 \mathrm{ft}$.

$1 / 8$ oz., 75 c......................... 20c

6565 Splendens (Scarlet Sage). Excellent for large beds and borders, brilliant scarlet; blooms July until frost; height, $3 \mathrm{ft}$. $1 / 8$ oz., $40 \mathrm{c} .$. . Pkt., 10c

6576 "Bonfire." Very free bloomer, the spikes grow erect and stand clear above the foliage; height, $2 \mathrm{ft} .1 / 8$ oz., 50c.................... 10k

6587 Early Dwarf Zurich. The plants are dwarf and compact; height, about 15 in.; earliest of all sorts. 1/8 oz., 75c................. 15kt.,

6589 Farinacea (Blue Sage). Long spikes of light blue flowers. A perennial but best grown as an annual. $2 \mathrm{ft} .1 / 8 \mathrm{oz}$, , 60c...........Pkt., 15c

6609 Patens (Blue Sage). Deep blue, a beautiful plant for the border or greenhouse, tender perennial. $2 \mathrm{ft}$. $1 / 8$ oz., $\$ 1.00 \ldots \ldots \ldots$. Pkt., $20 \mathrm{c}$

\section{SCHIZANTHUS}

(Butterfly Flower)

This is one of the most charming flowers for the garden in Summer and for the house in Winter. The plants are covered with a multitude of small butterflye like flowers of the most brilliant and striking designs. Hardy annual.

6732 Mixed. $11 \frac{1}{2}$ ft. $1 / 4$ oz., 25c..........Pkt., 5c

\section{SMILAX}

6743 Dark glossy green leaves make this very graceful climber an attractive window garden plant ............................ 10k

\section{SCABIOSA}

(Mourning Bride or Sweet Scabious)

Magnificent hardy annuals, commonly known as the Pincushion Plant, easy to grow, producing an enormous number of long, graceful stems crowned with 2-in. clusters of small flowers of the most delightful colors, white to rich velvety black purple. As a cut flower it is invaluable. $2 \mathrm{ft}$.

\section{LARGE FLOWERING ANNUALS}

6610 Azure Fairy. Lavender Blue..........Pkt., 10c 6621 Crimson. Rich shade.................. 10c 6632 Flesh-pink. Delicate shade...........Pkt., 10c 6643 King of the Blacks. Black purple.....Pkt., 10c 6654 Rose. Soft rose color.................., 10c

6665 White. Pure white.................... 10c

6676 Collection. Packet each of the above......50c Any of the above. $1 / 4$ oz. .............25c

6687 Mixed. 1/4 oz., 20c; oz., 60c........Pkt., 10c

\section{HARDY PERENNIAL VARIETIES}

6698 Caucasica (Blue Bonnet). Color soft blue. Fine cut flower, lasting a long time in water.

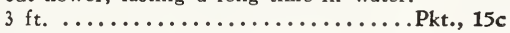

6699 Caucasica Alba. Pure white..........Pkt., 15c

6702 Caucasica Giant Hybrids. Flowers large with ruffled and fringed edges. $3 \mathrm{ft}$.......Pkt., 25c

6709 Japonica. Bushy plants, $2 \frac{1}{2} \mathrm{ft}$. with long wiry stems bearing heads of lavender-blue flowers. $1 / 4$ oz., 30c.......................... 10c

SCARLET SAGE. See Salvia.

SNAPDRAGON. See Antirrhinum.

\section{STATICE}

\section{( Sea Lavender)}

Broad panicles of small flowers which can be dried and used for Winter bouquets. Perennial.

6744 Latifolia. Deep lavender blooms.......Pkt., 10c 6745 Mixed. $1 / 4$ oz., 50c.................. 10c

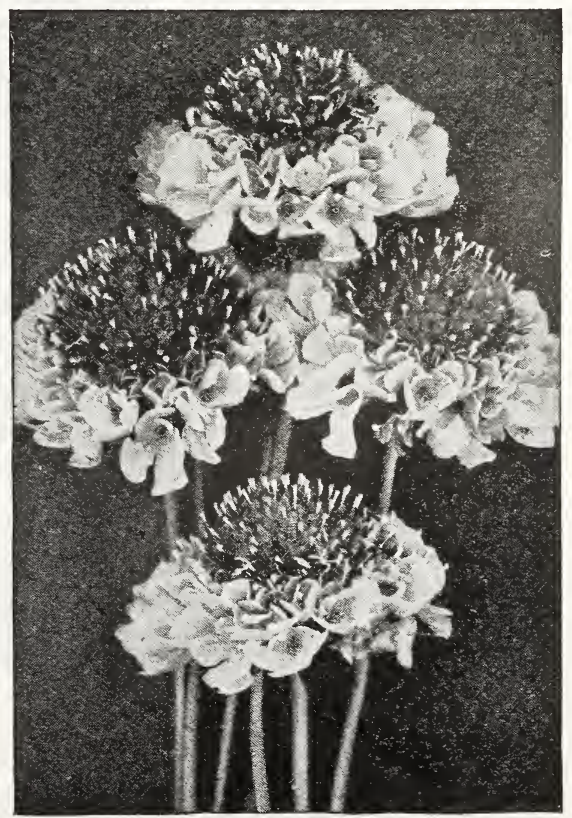

Sweet Scabiosa 


\section{Buist's Prize Sweet Peas}

THE wonderful range of colors, combined with the exquisite form of the flowers and the gracefulness of the stems and tendrils, make this the most popular of our annual flowers.

They are grown so easily and repay so grandly.

\section{CULTURE}

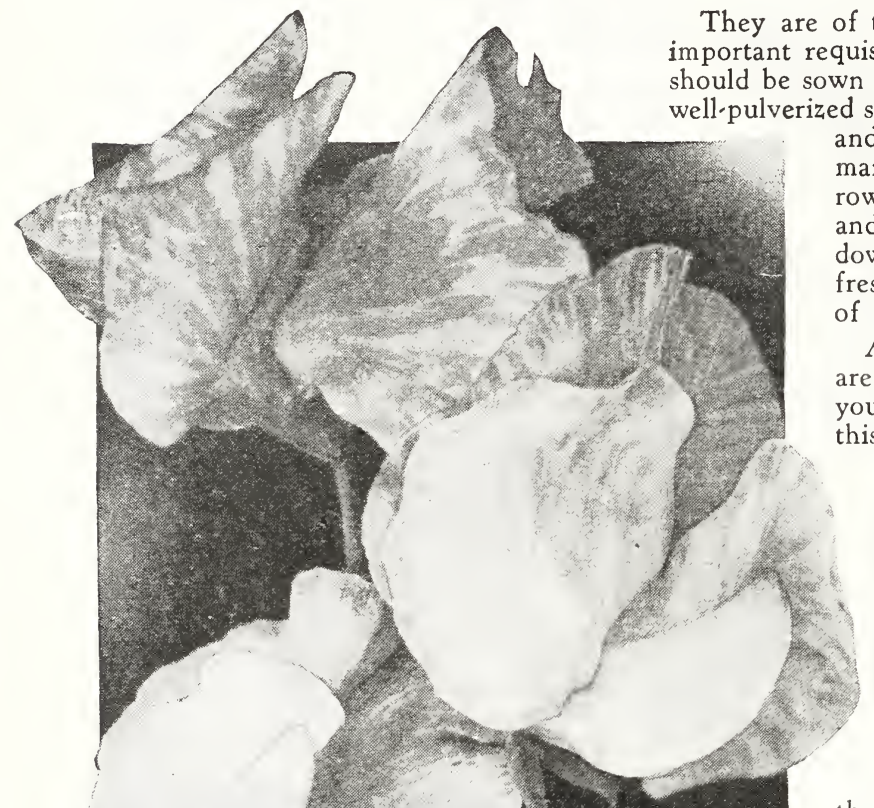

and enrich with well rotted stable manure or bone meal. Plant in rows 6 inches deep. Sow the seed and cover 2 inches, pressing the soil down firmly. Plenty of sunlight and fresh air are essential to the success of Sweet Peas.

As soon as the young seedlings are 2 inches high, thin out the young plants to 4 inches apart, as this will allow the air and light to circulate freely among the grow. ing vines, resulting in larger flowers, longer stems, better color and more blooms. Continue filling in 2 inches of soil at a time until the trench is filled; the plants will then become thoroughly established to with. stand warm weather and will continue flowering a much longer period than if sown in the ordinary way near the surface. When the plants are about 5 inches high, it is desirable to furnish some sup. port for the vines to run upon, preferably a wire netting firmly supported by stakes to prevent sag. ging; but strings or brush are used with satisfactory results.

Sweet Peas should not be grown in same soil year after year. Another very important feature that must not be overlooked is the clipping off of the flowers as they mature and fade, for if they are allowed to remain, they form their seed pods and then mature and the vines die.

The roots should not be allowed to become too dry. Water applied thoroughly once or twice a week, preferably early in the morning or in the evening after sundown, is usually better than light sprinkling more frequently.

Splendid results can be obtained in the Southern States by sowing in the Fall or early Winter. The plants become better established and the Buist's Prize Spencer Sweet Peas

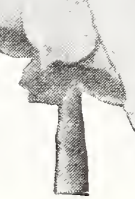
root growth stronger, prolonging the blooming period.
One ounce will plant a single row of 25 feet. 


\section{Buist's Prize Spencer Sweet Peas}

\section{SUMMER FLOWERING SPENCERS}

$\mathrm{T}$ HIS strain includes the largest and most beautifully formed Sweet Peas, truly gigantic in size, measuring 2 to $21 / 2$ inches across. They are beautifully formed with huge standards, open and upright and immense wings gracefully poised. Both standards and wings are delicately waved. Three and often four handsome blossoms are borne on long, strong stems, rendering them available as cut flowers for vases, bouquets and other decorations.

6950 Austin Frederick Improved. A lovely soft lavender, flowers of giant size.

6960 Avalanche. Large flowering white of exquisite form.

6970 Blue Bird. Beautiful clear blue. A new and distinct shade.

6980 Blue Picotee. White with blue edge.

6990 Camp Fire. The brightest pure flame-scarlet.

7000 Colne Valley. Light lavender blue. Very free blooming variety.

7020 Countess Spencer. Bright pink. An old favorite.

7030 Crimson King. Rich deep crimson.

7040 Dobbie's Cream. Primrose-yellow, flowers of large size on long stems.

7050 Edna May Improved. Pure white, large-waved flowers.

7060 Florence Nightengale. Beautiful clear lavender. Very large.

7070 Grenadier. A striking shade of bright geranium red.

7080 Hawlmark Pink. Lovely shade of salmon-pink.

7090 Heavenly Blue. Delphinium-blue, exquisitely waved.

7100 Hercules. A magnificent, large, soft rose-pink A great favorite at Sweet Pea exhibitions.

7120 Jack Cornwell. A lovely dark blue of enormous size and exquisite form.

7130 King White. The finest pure glistening white.

7140 Mammoth. Magnificent flowers of blazing orange-scarlet.

7150 Mary Pickford. Dainty cream-pink, suffused salmon.

7160 Miss California. A distinct shade of salmon pink.

7170 Mrs. Tom Jones. An unusually beautiful del phinıum-biue.

7180 Pinkie. Beautiful rose-pink. The best of the deep pinks.

7190 Powerscourt. Pure lavender, flowers of mam. moth size.

7200 Prince of Orange. Deep orange flowers on long stems. Very large.

7220 Royal Purple. Rich royal purple, immense Howers.

7230 The Sultan. Glossy black maroon.

7240 Warrior. A rich reddish maroon.

7250 What Joy. A rich deep primrose-yellow shade.

Price-Any of the above, Pkt., 10c; $1 / 2$ oz., $15 \mathrm{c}$; oz., 30c; 114 lb., \$1.00; lb., \$3.00.

7209 Buist's Prize Spencer Mixture. A matchless combination of most beautiful colors and gigantic in size. This unsurpassed mixture includes all the best Spencer sorts and comprises a splendid range of colors. There is nothing better no matter under what name or how high the price. One ounce will plant a single row of 25 feet. $1 / 2$ oz., 15c; oz., 25c; 1/4 lb., 75c; lb., \$2.50.

\section{EARLY OR WINTER FLOWERING}

This new class of early-flowering Spencer Sweet Peas are very popular with florists for greenhouse culture. They are particularly adapted to the Southern States where, if sown in the Fall or early Winter months will bloom three months from time of planting and will continue to flower until killed by the extreme heat.

The flowers are of fine size on long stems. Grown in the open ground, they begin flowering fully four weeks sooner than the Summer-flowering Sweet Peas sown at same time.

7378 All White. Largest and finest pure white.

7376 Aviator. Dazzling crimson-scarlet.

7382 Columbia. Salmon rose with white wings.

7385 Cream or Meadow Lark. Primrose yellow.

7388 Fair Maid. The best blush-pink variety.

7409 Glitters. Bright cerise. The best of its color.

7412 Harmony. A beautitul clear lavender.

7415 Lavender King. Rich, deep lavender.

7420 Mrs. Kerr. A fine shade of salmon.

7454 Rose Queen. A popular rose-pink.

7457 Snowstorm. Large, pure white.

7460 True Blue. Light violet blue.

7487 Yarrawa. The color, on opening, is rose, changing as the flower develops to a light pink, standard tinted buff with blush wings.

7490 Zvolanek's Rose. Extra large, rich rose.

Price. Any of the above Winter flowering varieties: $1 / 2$ oz., 30c; oz., 50c............Pkt.,10c 7498 Collection. A packet each of the above 14 Early Winter flowering varieties......\$1.00

7509 Mixed Early or Winter Flowering. A mixture of all the above colors. $1 / 2$ oz., $25 \mathrm{c}$; oz., 40 c; $1 / 4$ lb., $\$ 1.25 \ldots \ldots \ldots \ldots \ldots \ldots \ldots \ldots$. Pkt., 10c

\section{BEST SUMMER FLOWER- ING SPENCER SWEET PEAS}

\begin{tabular}{ll}
\multicolumn{2}{c}{ Collection No. 7215} \\
One packet each for 60c \\
King White & White \\
Heavenly Blue & Light Blue \\
Jack Cornwell & Dark Blue \\
Crimson King & Crimson \\
Camp Fire & Scarlet \\
Powerscourt & Lavender \\
Prince of Orange & Orange \\
Miss California & Salmon Pink \\
Mary Pickford & Cream Pink \\
The Sultan & Maroon
\end{tabular}

GRANDIFLORA SWEET PEAS

The Grandiflora is the well-known type which has been grown for many years, the flowers are not as large as the Spencers, but they are, however, more easily grown and decidedly cheaper.

7343 Grandiflora Mixed. oz., 15c; 1/4 lb., 40c; lb., $\$ 1.25 \ldots \ldots \ldots \ldots \ldots \ldots \ldots \ldots \ldots$. Pkt., $5 \mathrm{c}$

\section{CUPID OR BEDDING SWEET PEAS}

7365 Dwarf Cupid Varieties Mixed. Plants are 6 inches high and form a dense mat of emerald green foliage, and from June until late Summer are literally a sheet of bloom.

Oz., 15c; 1/4 lb., 50c; lb., \$1.75......Pkt., 5c 


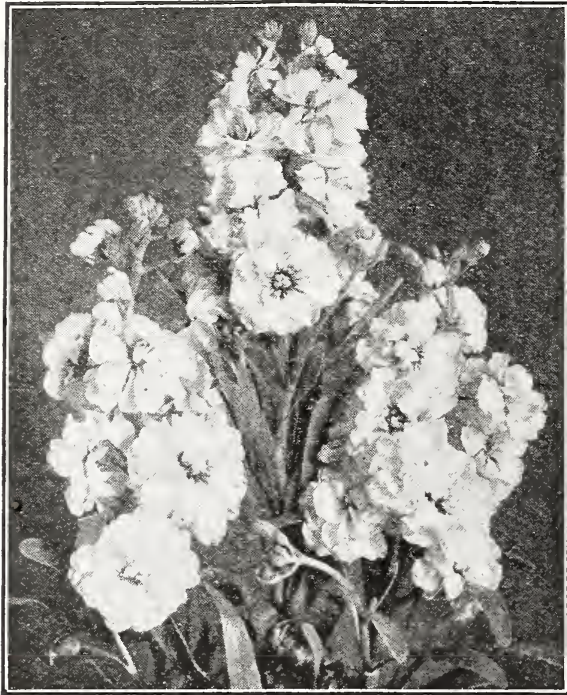

Stocks

\section{STEVIA}

Free-blooming plants, bearing a multitude of fra. grant pure white flowers; suitable for Summer or Winter blooming; largely used for cutting. $2 \mathrm{ft}$.

6754 Serrata ............................ 10c

\section{STOKESIA}

(The Hardy Cornflower)

A rare, choice, American hardy perennial plant of great beauty, that blooms the first year from seed i started early. Blooms from July till frost. 1 to $2 \mathrm{ft}$.

6765 Cyanea. Light blue...............Pkt., 10c 6776 Alba. Pure white.......................... 10c 6787 Cyanea Mixed. $1 / 4$ oz., 50c.........Pkt., 10c

\section{STOCKS}

\section{(Gilliflower)}

Great favorites because of their charming colors, delightful fragrance and the abundance of blooms, whether grown for bedding purposes in Summer or as cut flowers in Winter. Half-hardy annual. $1 \frac{1}{2} \mathrm{ft}$.

\section{LARGE FLOWERING TEN WEEKS' STOCKS}

6798 Blood Red ......................... 10c

6809 Light Blue

6810 Bright Pink .............................. 10c

6821 Purple $\ldots \ldots \ldots \ldots \ldots \ldots \ldots \ldots \ldots . \ldots \ldots$ Pkt., 10c

6832 Pure White ........................., 10c

6843 Canary Yellow ................................ 10c

6854 Collection. Pkt. each of the above.......50c

6865 Mixed Colors. 1/8 oz., 50c..........Pkt., 10c

\section{MAMMOTH FLOWERING BEAUTY STOCKS}

This is a recently developed strain of early Winter. flowering or Brompton Stocks with very large double flowers which have a delightful fragrance. The plants bear long spikes of bloom which are extremely desirable for cutting. For Winter blooms sow seed July to September.

6914 Beauty of Nice. Delicate flesh-pink; an extremely popular sort...............Pkt., 10c

6915 Crimson King Rich crimson.............. 10c

6916 Mont Blanc. Purest white.................. 10c

6917 Heatham Beauty. Rich mauve, shaded

terra cotta ...................Pkt., 10c

6918 Queen Alexandra. Rosy.lilac...................... 10c

6919 Summer Night. Rich deep blue........Pkt., 10c

6920 Collection of above six colors............50

6921 Choicest Mixed. $1 / 8$ oz., 60c................ 10c

\section{STOCKS-Continued}

\section{CUT AND COME AGAIN-10 WEEKS' STOCKS}

Plants of robust growth and branching habit. If sown early commences blooming in June and continues until frost. Fine for cutting.

6876 Princess Alice. Pure white............ Pkt., 10c 6887 La France. Light pink .............. Pkt., 10c 6898 Brilliant. Deep rose-crimson..........Pkt., 10c 6909 Sapphire. Dark blue..................... 10k 6910 Creole. Creamy-yellow ................... 10c 6911 May Queen. Delicate lilac.............Pkt., 10c 6912 Collection. One packet each...........50c 6913 Mixed. All colors. $1 / 8$ oz., 60c............. 10c SUNFLOWER. See Helianthus.

\section{SWEET ROCKET (Hesperis)}

Delicious sweet-scented hardy perennials, also known as Dame's Violet and Dame's Rocket; grows 2 to $3 \mathrm{ft}$. high and bears spikes of showy white lilac and purple fragrant flowers. Very effective in hardy border.

7510 Mixed. $1 / 4$ oz., 20c.................. 5 kt.

SWEET SULTAN. See Centaurea.

\section{SWEET WILLIAM}

\section{(Dianthus Barbatus)}

Another old-time favorite because of its great mass of brilliant colors-white, pink, rose to dark red-and ease of growth. The $21 / 2$-in. broad flowerheads are borne on 1 . ft. stems. Fine for cut flowers. May.June. Hardy perennial. 1 to $11 / 2 \mathrm{ft}$.

7521 Single White ......................... 10c 7532 Single Crimson ....................... 10c 7543 Single Pink Beauty...................... 10c 7554 Single Scarlet Beauty.................., 10c 7565 Collection. Packet each of above.........30c 7576 Single Mixed. 1/4 oz., 25c................ 10c 7598 Giant Double Mixed. Double flowers in a great variety of colors and shades. An improved strain. $1 / 4$ oz., 40c................. Pkt., 10c

TASSEL FLOWER. See Cacalia.

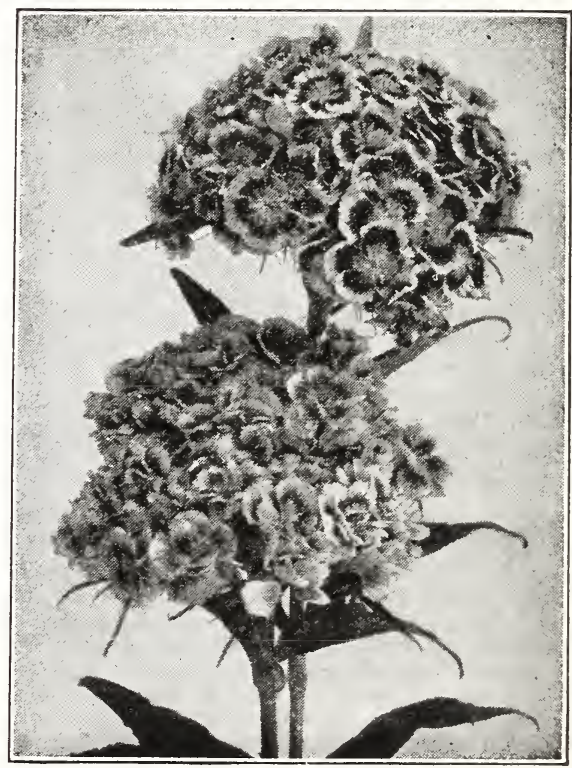

Sweet William 


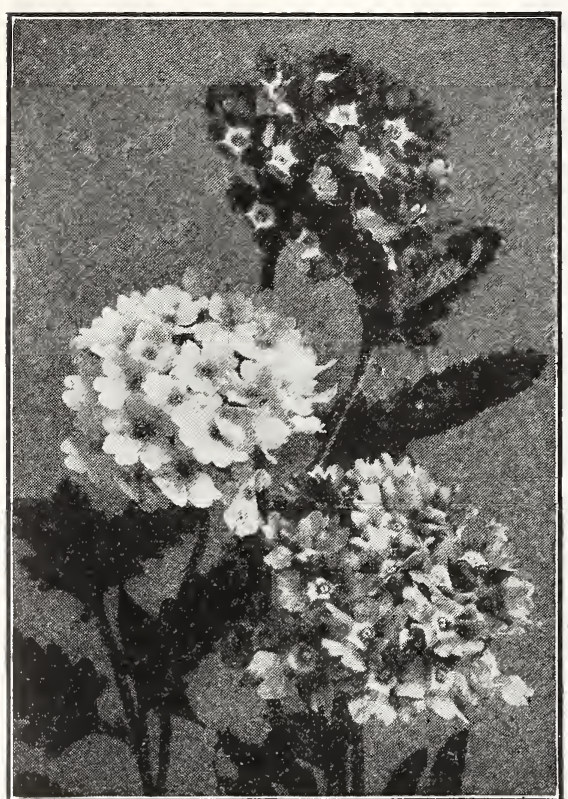

Buist's Mammoth Verbena

\section{THUNBERGIA}

\section{(Black-Eyed Susan)}

A vory delightful slender trailing vine with neat

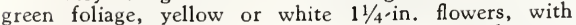
dark or black centers. A splendid plant for hanging pots and porch boxes. Annual. $5 \mathrm{ft}$.

7610 Fine Mixed. $1 / 4 \mathrm{oz}, 30 \mathrm{c}, \ldots \ldots \ldots \ldots . .$. Pkt., 10c

\section{TORENIA}

Small, bushy plants with pretty snapdragon-like blue flowers. For edging beds or for pot culture, indoors it is both useful and attractive. Blooms all Summer. Annual. $1 \mathrm{ft}$.

7621 Fournieri

.Pkt., 15c

\section{TRITOMA}

(Flame Flower, Red Hot Poker)

In late Summer and Fall the garden is illuminated by magnificent, foot-long spikes of orange-red flowers. Hardy in the open ground south of Philadelphia. North dig up and store in sand in the cellar over Winter. Perennial. $3 \mathrm{ft}$.

7632 Hybrida Mixed ...................... 10c

\section{VALERIANA}

\section{(Garden Heliotrope)}

Lavender flowers with delicate heliotrope odor. June-July. Hardy perennial. $2 \mathrm{ft}$.

7643 Mixed Colors. 1/4 oz., 25c...........Pkt., 10c

\section{VERONICA}

(Speedwell)

Long, narrow spikes of small, delightful flowers produced abundantly in June to October. Requires cool, moist soil and prefers shaded situations. 2 to $3 \mathrm{ft}$.

7754 Spicata. Bright blue. 1/8 oz., 40c....Pkt., 10c

\section{FOR HANGING BASKETS AND} WINDOW BOXES

Alyssum, Asparagus Sprengeri, Lobelia, Maurandia, Nasturtium, Petunia, Verbena.

\section{BUIST'S MAMMOTH VERBENAS}

Sweetly-scented flowers in large clusters, in a great variety of colors, white to dark red, borne in profusion from June till frost, makes the Verbena a desirable bedding plant. Sow seed indoors in early March. Annual. $1 \mathrm{ft}$.

7654 Defiance. Scarlet .................... 10c

7665 Pure White........................... 10c

7676 Pink .........................., 10k

7687 Blue .........................., 10c

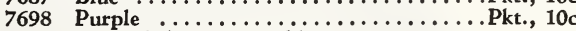

Any of the above. $1 / 4$ oz. ............50c

7709 Collection. One packet each............40c

7710 Buist's Mammoth Mixed. Flowers of large

size, $1 / 4$ oz., 40c.................. $10 c$

7743 Citriodora (Lemon Scented Verbena). An old favorite with fragrant leaves...........Pkt., 10c

7744 Erinoides (Moss Verbena). Unique in its finely divided foliage and small rosy-lilac to deep purple and white flowers. Annual.

$1 \mathrm{ft} . \ldots \ldots \ldots \ldots \ldots \ldots \ldots \ldots \ldots \ldots$ Pkt. $10 \mathrm{c}$

7745 Venosa (Hardy Garden Verbena) A dwarf form, much used for bedding with bright purple and heliotrope flowers, June to frost. Perennial. Start seeds in January. $1 \mathrm{ft}$.

$1 / 4$ oz., 30c...................Pkt., 10c

\section{VINCA ROSEA}

\section{(Periwinkle)}

Attractive, bushy plants with shining light green foliage. $1 \frac{1}{2}$ to $2 \mathrm{ft}$. high, which may be used for bedding outdoors in Summer or as pot plants in win. dow garden and greenhouses. Tender annual; blooms all Summer.

7765 Alba. White with dark eye..........Pkt., 10c 7776 Alba Pura. Pure white................... 10c 7787 Rosea. Rose, dark eye..................... 10c 7798 Mixed. All the colors. 1/4 oz., 40c...Pkt., 10c

\section{VIOLET}

\section{(Sweet-Scented)}

Violets are easily grown from seed, but the seeds require a long time to germinate. The plants require cool, moist soil. Hardy perennial.

7809 Single Blue Czar...................... 7810 Single White Czar........................ 10c 7821 Single Mixed. Blue and white.........Pkt., 10c

\section{WALLFLOWER}

Deliciously fragrant flowers in brilliant colors. Half hardy perennial requiring protection in a cold frame over Winter, 1 to $1 \frac{1}{2} \mathrm{ft}$

7832 Single Mixed. 1/4 oz., 20c..........Pkt., 10c 7843 Double Mixed ........................ 15c

\section{WILD FLOWER GARDEN}

This is a mixture of easily grown annuals, which thrive with little care; they are not wild flowers nor weedy. There is a great opportunity to use them in your vicinity. They may be sown along fences, em bankments or rough ground. The cheery flowers will change an unsightly corner into a gay, beautiful place. Think of the pleasure you will be giving passers-by if you buy a pound and sow it thickly on unsightly road embankments or similar places. It is a little thing to do, but will improve your locality, make it a better place to live. Try it this Summer.

7854 Mixture. $1 / 2$ oz., 15c; oz., 25c; $1 / 4$ lb., $75 \mathrm{c}$; lb., \$2.50 ....................... Pkt., $5 c$

\section{FOR SHADY AND PARTLY SHADED PLACES}

Achillea, Begonia, Bellis, Campanula, Columbine, Cowslip, Coreopsis, Foxglove, Kenilworth Ivy, Lobelia, Minulus, Myosotis (Forget-mernot), Pansy, Poppy (Perennial), Viola. 


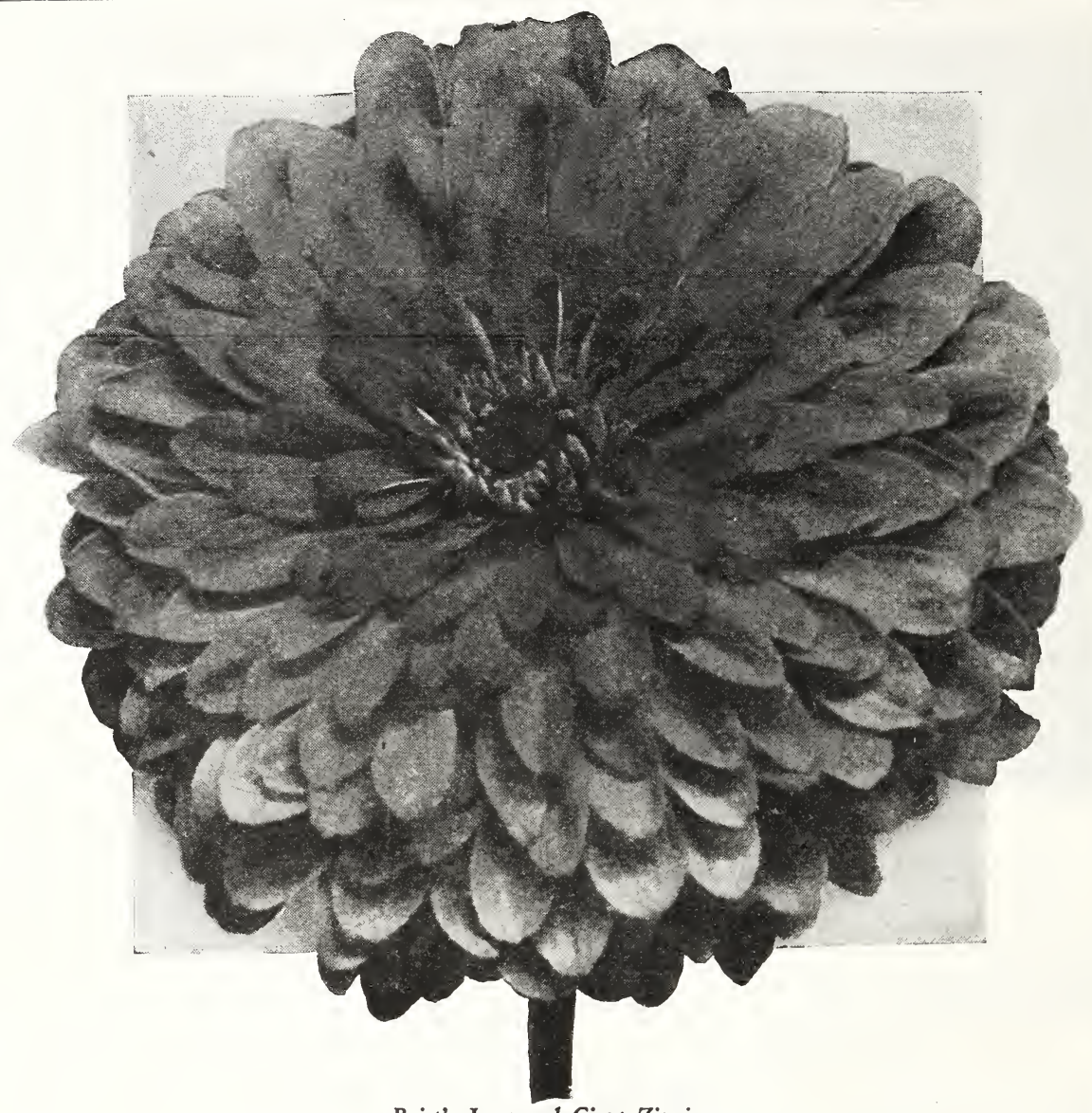

Buist's Improved Giant Zinnia

\section{ZINNIA}

\section{(Youth and Old Age)}

These indispensable garden annuals are remarkable for the duration and profusion of their flowers, furnishing the entire Summer an abundance of large double flowers of varied and brilliant colors, each flower keeping perfect for weeks before fading. During the past few years there has been a great revival of interest in the Zinnia flower. Plant breeders have tried to excel one another in improving the existing forms, and are bringing new ones each year to the attention of the flower lover. There are, of course, many varieties of diverse forms and various colors, but those we list are the best and most desirable. They all bear an abundance of bloom and are especially valuable because they give to the garden a wealth of color; at a time when other flowers and plants are beginning to fade away, such are their lasting qualities.

Sow seed early in the Spring in the open ground in good rich soil, covering about one-half inch deep. When the young plants are 2 inches high, thin to 18 inches apart each way, as they are robust growers and require a large amount of space to attain maximum size.

\section{BUIST'S IMPROVED GIANT ZINNIA}

A very special strain of Zinnia producing immense sized blooms-4 to 5 in. across not unusual-on $3 \cdot \mathrm{ft}$. tall plants. The double flowers are semi-globular in shape and are produced abundantly all Summer until late Autumn. Although tall and erect in growth, they require no support, being sturdy and deep rooted. Fine as a cut flower or for bedding purposes.

8176 Lemon Queen. The petals are light canary on the upper and cerise on the lower side, the two colors blending as the flower developes. It is the only Zinnia with fragrance.

$1 / 4$ oz., 50c......................... 15k

8178 Enchantress. Light rose with center a deep rose. $1 / 4$ oz., 50c..................... 15c 8180 Cerise Queen. A beautiful shade of cerise rose. $1 / 4$ oz., 50c.........................., 15c

8182 Miss Wilmott. A charming soft but brigbt rose pink. $1 / 4$ oz., 50c....................... 15c orange-red. $1 / 4$ oz., 50c.............Pkt., 15c

8189 Orange Queen. Golden yellow. $1 / 4$ oz., 50c......................... 15k 8200 Pink Profusion. Delicate shrimp pink, very large. $1 / 4$ oz., 75 c..................... 8209 Purity. A clean pure white.

1/4 oz., 50c........................ 15k

8210 Rose Queen. Bright rose with deep rose-red center. $1 / 4$ oz., 50c..................... 15c

8212 Scarlet Gem. A rich and striking shade.

$1 / 4$ oz., 50c.......................... 15c

8221 Collection. Packet each of the above...\$1.00 8232 Giant Mixed. All colors.

$1 / 4$ oz., 35c; $1 / 2$ oz., 60c; oz., $\$ 1.00 \ldots$. Pkt., 15c 


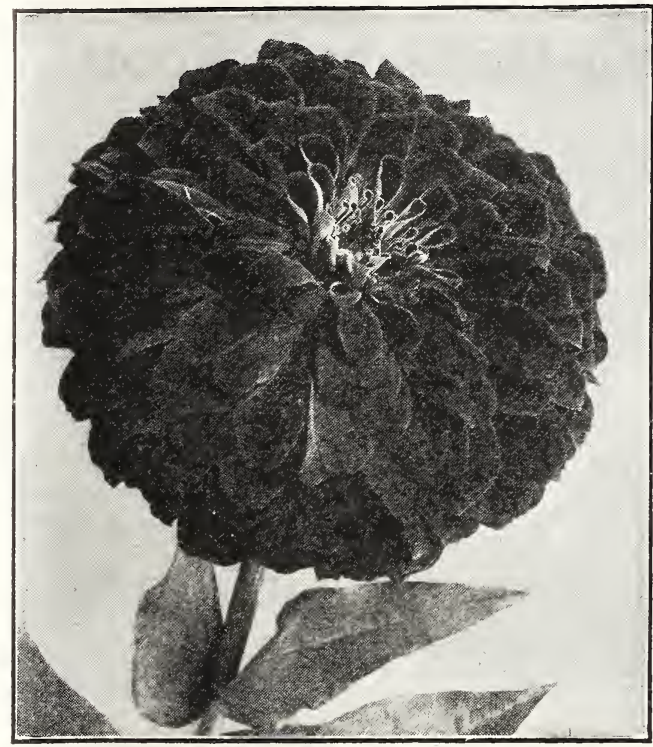

Zinnia (Dahlia Flowered)

\section{DAHLIA FLOWERED ZINNIAS}

This wonderful big Zinnia is the latest development in this popular annual. The plant attains a height of 3 feet, producing mammoth flowers averaging 4 to 6 inches across by 2 inches in depth, and in form is like a perfect decorative Dahlia. It is of vigorous growth and produces an abundance of brilliant colored flowers throughout the Summer and early Fall.

8100 Butterfly. Flowers very large of deep creamy yellow ............................... 20c

8105 Canary Bird. A delicate shade of primrose, flowers large .......................... 20c

8109 Crimson Monarch. Immense flowers of flaming crimson .......................... 20c

8110 Exquisite. Light rose with center a deep rose. (Tyrian Rose.) ...................Pkt., 20c

8121 Golden State. A rich orange-yellow...Pkt., 20c 8125 Lemon Beauty. Golden-yellow on brown, fine pastel shade ........................., 20c

8130 Oriole. A striking two-color flower, orange and gold, changing slightly as it ages, but at all times worthy of the beautiful bird for which it is named .......................... 20c 8132 Polar Bear. A very large pure white...Pkt., 20c 8143 Scarlet Flame. Beautiful bright scarlet, very large ................................ 20c Any of the above, $1 / 8$ oz. ............60

8154 Collection. Packet each of above......\$1.25 8165 Mixed. All colors. 1/4 oz., 50c.......Pkt., 15c

\section{DOUBLE DWARF}

Considered the best Zinnia for bedding, forming large bushy plants not over 2 feet high, bearing large perfect double flowers in good clear distinct colors.

7954 Yellow. 1/4 oz., 25c..............Pkt., 10c 7965 Scarlet. 1/4 oz., 25c...................., 10c 7976 Orange. $1 / 4$ oz., 25c..................., 10c 7987 Salmon-Rose. $1 / 4$ oz., 35c................., 10c 7998 White. 1/4 oz., 25c................Pkt., 10c 8009 Crimson. $1 / 4$ oz., 25c...............Pkt., 10c 8010 Collection. One packet each...........50 8021 Mixed. 1/4 oz., 20c; oz., 50c........ Pkt., 10c

\section{DOUBLE LILLIPUT OR POMPOM ZINNIAS}

This charming little Zinnia is used for bed. ding or borders. It grows about 18 inches high and bears a profusion of comparatively small, very double, globular flowers about 1 inch in diameter, very brilliant in color. They are very pretty plants, bloom all Summer until very late in the Fall. They are replacing the Double Dwarf type for bedding and cut flower purposes. Salmon Rose and Crimson Gem are especially useful to florists.

8048 Canary Yellow ..............Pkt., 10c 8049 Golden Gem ........................, 10c 8050 Crimson Gem ...............Pkt., 10c 8051 Salmon Rose ...................., 10c 8052 White Queen ...................... 10c Any of the above, $1 / 4$ oz. ........30c

8053 Collection. Packet each of above. 40 8054 Mixed. All the colors.

$1 / 4$ oz., 25 c................ Pkt., 10 c

\section{VARIOUS ZINNIAS}

GIANT PICOTEE. The flowers of this type are picoteed at edge of the petals with a color distinct from the body of the flower.

8065 Giant Picotee Mixed.

876 oz., 40c..................... 15c 8076 Picotee. Golden Pheasant. Flowers of a deep orange with maroon tips.

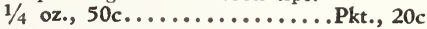

VICTORY. A very distinct variety with large, densely double, quilled flowers. The colors are mostly in salmon, old rose, deep rose, lilac and dark red tones.

$80851 / 4$ oz., 40c....................... $15 \mathrm{c}$

CURLED AND TWISTED. Large double flowers, petals curled and twisted into graceful forms. $2 \mathrm{ft}$. $80431 / 4$ oz., 25c.......................... 10

RED RIDING HOOD. Bushy plant covered the entire season with small intense scarlet flowers. $1 \mathrm{ft}$. $80321 / 4$ oz., 25c.......................... 10 c

MEXICANA. Beautiful small flowers ranging in color from yellow to brown. They are extremely free. flowering and pretty. $1 \mathrm{ft}$.

$80451 / 4$ oz., 50c...................... 15k

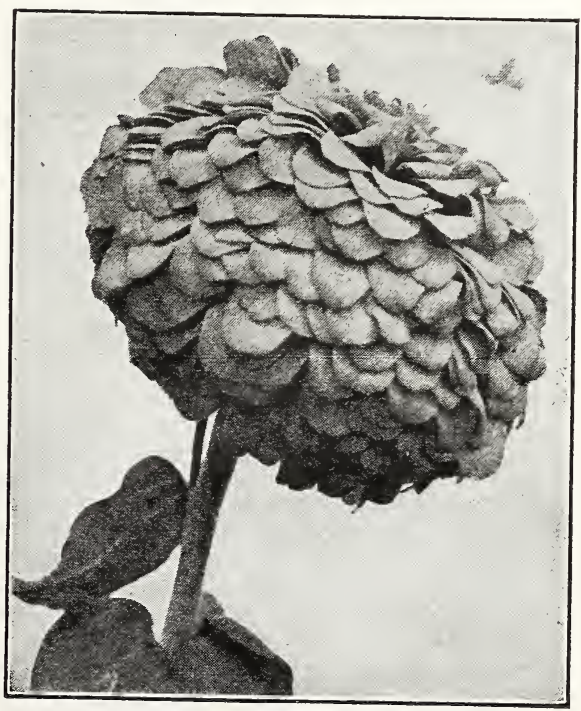

Large-Flowering Double Dwarf Zinnia 


\section{Summer-Flowering Bulbs and Roots}

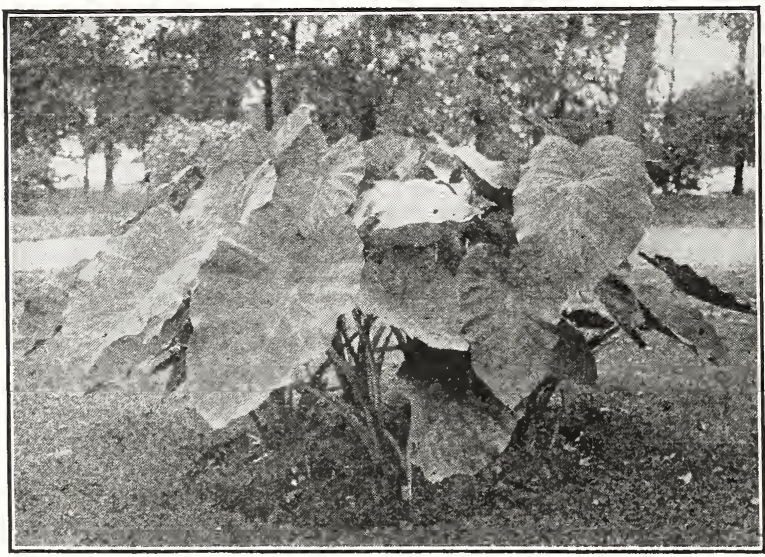

Caladium Esculentum (Elephant's Ear)

\section{AMARYLLIS}

The Amaryllis produces showy flowers that are handsome and very attractive, resembling Lilies. The most suitable soil is good loam, with one-fourth part of leaf-mold, or pulverized manure, and some sand. Good drainage is very important. The growing season is from early Spring until about September, when the plants should be kept cool and allowed to rest until February. They require plenty of sunshine, but in the flowering season a light shading tends to preserve the blossoms longer. Frequent disturbance of the roots is to be avoided. Established bulbs in large pots should have a top dressing each year when starting, and manure'water during the growing season.

EQUESTRA. Also known as Barbados or Gloriosa Lily. Produces large, bright red flowers with green and white throat. $30 \mathrm{c}$ each; three for $75 \mathrm{c}$, postpaici.

GIANT HYBRIDS. The finest of the Amaryllis family, exceeding in size and fine form of their flowers as well as in the diversity of colors and markings all former hybrids. Flower stalks are usually from two to three feet in height, bearing from four to six gigantic blooms of the most perfect form. Selected bulbs, $60 \mathrm{c}$ each; three for $\$ 1.50$, postpaid.

JOHNSONI. An elegant pot plant, with crimson flowers 5 inches in diameter, each petal striped with white. $40 \mathrm{c}$ each, postpaid.

\section{BEGONIAS}

\section{(Tuberous Rooted)}

There is hardly a garden in which there are not semi or entirely shaded spots where the average flower will not grow. Such places are ideal for this flower; yet it will make a dazzling show in the open. Enormous wax. like flowers appear uninterruptedly from June till frost. The bright flowers contrast well with the deep-colored foliage. The bulbs must be lifted in the Fall.

SINGLE BEGONIAS. Crimson, orange, pink, scarlet, white, yellow. Each $20 \mathrm{c} ; \$ 2.00$ per doz., postpaid.

DOUBLE BEGONIAS. Crimson, orange, pink, scarlet, white, yellow. Each 25 c; $\$ 2.50$ per doz., postpaid.
COME of the most beautiful flowers we have are grown from bulbs, and their culture is very easy. In the Spring, when danger of frost is over, plant in a rich loamy soil having a sunny position. They flower with great certainty during Summer and Fall. The hardy sorts may remain in the ground over Winter, but the tender ones should be taken up and stored away in a dry, cool place until planting time the next Spring.

\section{CALLA LILIES}

Very useful Summer-blooming plants of the easiest cultivation. Splendid as a pot-plant or for growing outdoors, preferring a shaded location. They re quire good rich loam and should be planted when danger of frost is over in the Spring, and will then flower during the Summer months. When the tops are killed by frost in the Autumn, dig and store during the Winter in a cool place.

GOLDEN YELLOW CALLA. This is the Yellow Calla of marvelous beauty, the flowers being as large as the popular white Winterflowering variety and is of a rich lustrous golden yellow. The foliage is dark green with numerous white spots which gives the plant a very ornamental appearance.

Mammoth bulbs, 35c each; $\$ 3.50$ per doz; postpaid Strong bulbs, 25c each; $\$ 2.50$ per doz.; postpaid.

\section{CALADIUM ESCULENTUM}

\section{(Elephant's Ear)}

A fine tropical plant that is easily grown and very effective for beds, borders or for planting out on the lawn. It will grow in any good garden soil and is of the easiest culture. The soil best suited to Caladiums is a mixture of fibrous loam, leaf mold, peat and well rotted cow or sheep manure in equal parts, with a sprinkling of sand added. Bulbs may be planted out doors as soon as danger of frost is over, covering about 3 inches deep. To obtain the best results, it should be planted where it will obtain plenty of water. Foliage light green. When full size, it stands 4 to 6 feet high, and bears immense leaves, 3 to 4 feet long by $2 \frac{1}{2}$ feet wide.

\begin{tabular}{lrrr} 
& Each & \multicolumn{1}{c}{ Doz. } & 100 \\
Monster bulbs $\ldots \ldots \ldots \ldots \ldots$ & $\$ 0.50$ & $\$ 5.00$ & $\$ 30.00$ \\
Mammoth bulbs $\ldots \ldots \ldots \ldots \ldots$ & .30 & 3.50 & 25.00 \\
First-size bulbs $\ldots \ldots \ldots \ldots \ldots$ & .20 & 2.00 & 15.00 \\
Secon & .20 & 1.50 & 10.00
\end{tabular}

Second size bulbs ........ $15 \quad 150 \quad 10.00$

Single bulbs mailed free. Quantities quoted by the dozen and hundred will be forwarded by express at purchaser's expense.

FANCY-LEAVED VARIETIES. Fine for decorating the conservatory, greenhouse and window boxes, also for planting outdoors when ground has become warm. Each, $30 \mathrm{c}$; six for $\$ 1.60$; per doz., $\$ 3.00$, postpaid.

\section{CINNAMON VINE}

A rapid,growing climber, taking its name from the peculiar fragrance of the delicate white flowers. The leaves are heart-shaped, bright glossy-green; growth is very rapid, often running 25 to 40 feet; quite hardy. Large select roots. $10 \mathrm{c}$ each, three for $25 \mathrm{c} ; \$ 1.00$ per doz., postpaid. 


\section{CANNAS}

The most beautiful of all bedding plants, producing rich tropical foliage as well as an abundance of dazzling blooms in many shades. The flowers range in color from yellow and orange to scarlet and deep crim. son and the plants bloom continuously from time of planting until cut down by frost.

Plant Cannas about 18 inches apart each way, the tall varieties for center of bed and dwarf growing for border. For a round bed 7 feet in diameter it will take nineteen plants.

\section{GREEN-LEAVED CANNAS}

Fiery Cross. $5 \mathrm{ft}$. Scarlet shading to crimson. Very attractive.

Eureka. $41 / 2 \mathrm{ft}$. Considered the finest white Canna. Blooms freely all season.

Hungaria. $31 / 2 \mathrm{ft}$. Rich peach blossom pink, a continuous bearer. Flowers very large, with immense petals. Ideal for bedding.

Gladiator. $41 / 2 \mathrm{ft}$. The flowers are bright yellow, hickly dotted with crimson. Very free bloomer.

Madame Crozy. $3 \mathrm{ft}$. Brilliant vermilion-scarlet flowers, edged yellow. Bright green foliage.

Meteor. $4 \mathrm{ft}$. Immense brilliant crimson heads of large round petaled flowers.

The President. $4 \mathrm{ft}$. This gorgeous variety produces giant flowers of a rich glowing scarlet color, often measuring 7 inches across when fully opened.

Wintzer's Colossal. $5 \mathrm{ft}$. Bright scarlet flowers of immense size. The plant is a strong vigorous grower and very free flowering.

Yellow King Humbert. $4 \mathrm{ft}$. A green-leaved sport of the King Humbert. It has the same habit and growth and free-tlowering qualities, but the flowers a re a deep rich yellow spotted and blotched with bright red.

Richard Wallace. $4 \mathrm{ft}$. An ideal bedder, color canary yellow. Free bloomer.

Price-Any of the above, $15 c$ each; $\$ 1.50$ per doz., postpaid. By express or freight, $\$ 10.00$ per 100 .

City of Portland. $31 / 2 \mathrm{ft}$. Bright rosy'pink, a freeflowering vigorous bloomer.

Mrs. Alfred C. Conrad. $4 \mathrm{ft}$. The "Queen of Cannas." Produces gigantic flowers of beautiful salmon pink.

Rosea Gigantea. A giant in size of flower, color a soft rose, shading to carmine-pink. A wonderful bloomer.

Price-Any of the above three varieties, 20c each; $\$ 2.00$ per doz., postpaid. By express or treight, $\$ 12.00$ per 100.

\section{BUIST'S SELECTION O}

Cigarette (Hybrid Cactus). Scarlet tipped white flowers 7 inches across, carried erect on long stiff stems; an early, free and continuous bloomer. 75c each.

Colossal Pink (Cactus). Clear pink tinting lighter at tips of petals, a truly colossal flower. $75 \mathrm{c}$ each.

Golden Jubilee (Decorative). Rich golden yellow. Fine for cutting. \$1.00 each.

Jersey Beauty (Decorative). A prize win. ning variety. Blooms are of immense size, carried high above the foliage on long stiff stems. Color a beautiful shade of rose'pink. 75 c each.

Leo Niessen (Decorative). Color a bril. liant cardinal-red, produced on long stiff stems; an early and continuous bloomer. Excellent cut flower. $\$ 1.00$ each.

Mary Dorr (Cactus). One of the most beautiful of all Cactus Dahlias. The long twisted petals are bright Tyrian pink, blend. ing to white at center and tips. A free bloomer. $75 \mathrm{c}$ each.

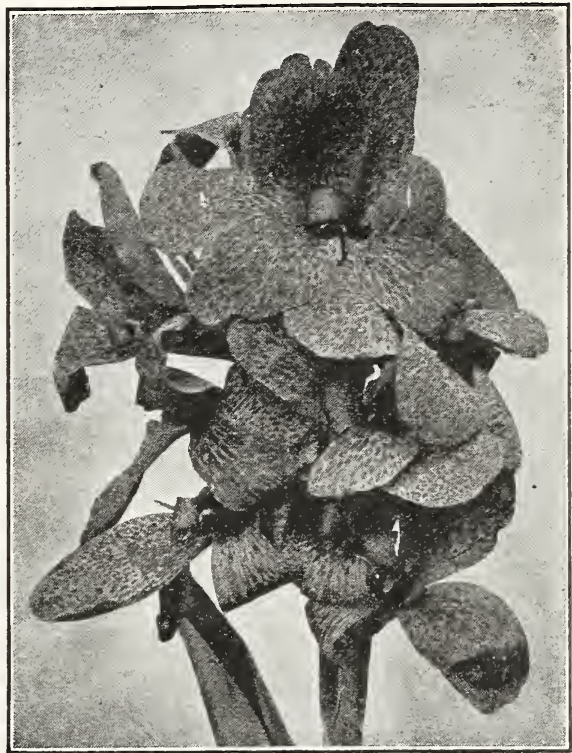

Buist's Superb Cannas

\section{BRONZE-LEAVED CANNAS}

David Harum. Bright vermilion scarlet. Very free bloomer. $3 \mathrm{ft}$.

King Humbert. "King of All." $4 \mathrm{ft}$. Bears im. mense brilliant orangerscarlet flowers streaked with crimson and gold, in gigantic trusses. Foliage rich coppery-bronze.

Shenandoah. $4 \mathrm{ft}$. Flowers beautiful, rosy pink, borne in large clusters. A fine bedder.

Nokomis. 4 to $5 \mathrm{ft}$. Bears immense trusses of vivid crimson flowers, foliage very dark green, heavily veined and edged with bronze.

Prices-All varieties, $15 \mathrm{c}$ each; $\$ 1.50$ per doz., postpaid. By express or freight, $\$ 10.00$ per 100 .

The Ambassador. A vigorous free-flowering cherry red. $5 \mathrm{ft}$. $20 \mathrm{c}$ each; $\$ 2.00$ per doz., postpaid.

\section{F COLOSSAL DAHLIAS}

Mahogany (Cactus). Dark velvety-red, of good size, with full center and produced on long stems. 75c each.

Senator Baird (Decorative). A grand flower of gigantic size. The color is a rich glowing red. The stems are long, stiff and hold the flower upright. It is the finest of all red Decorative Dahlias for exhibition or the garden. $75 \mathrm{c}$ each.

Wissahickon (Cactus). Red tipped buff, flowers 8 inches across produced freely on long stems. $50 \mathrm{c}$ each.

Collection Offer-One each of the above Colossal Dahlias. Value $\$ 7.00$ for $\$ 5.00$, postpaid.

Rodman Wanamaker (Decorative-Peony). A wonderful color effec in Autumn shades and tints; the color is entirely distinct from any other variety. The buds are light lemon color and as each petal expands, the color changes to golden salmon with bronze suffusion. Immense blooms on long stiff stems. $\$ 1.50$ each. 


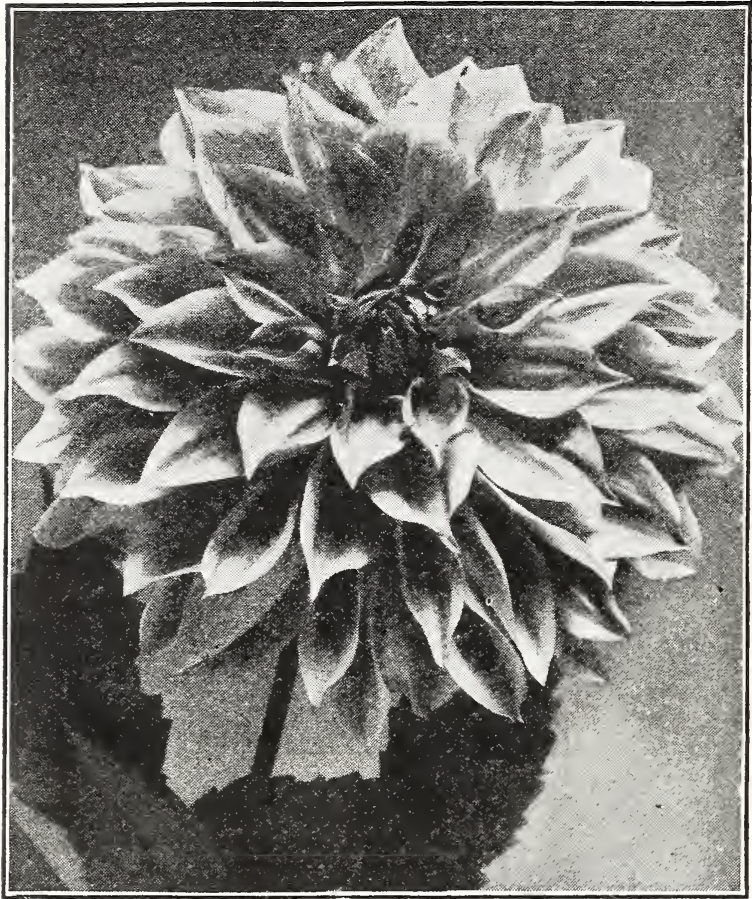

Decorative Dahlia "Mina Burgle"

\section{DAHLIAS}

Dahlias can be grown in any good soil, but they succeed best in an open sunny situation, with plenty of room and the ground kept light. If your soil is very heavy, a load or two of sand mixed in will be beneficial; in the absence of sand, coal ashes will make a good substitute. Dahlias need plenty of moisture and must have good drain. age. There is no plant more responsive to kind treatment. Plant when the ground is warm, covering the tubers 3 inches deep, laying the bulb on its side. If many shoots start up, thin out to one or two. When the plant is 6 or 8 inches high, pinch out the center shoot, which will cause it to spread.

The "Decorative" types are charac terized by gracefully formed flowers of large size with broad petals, being in. termediate in form between the compact "Ball" sorts, which are nearly round, and the "Cactus" varieties, which have loosely formed blossoms with long twisted petals.

The Peony.Flowered are of large size, with broad petals, artistically curled and twisted.

\section{SELECT DECORATIVE DAHLIAS}

\section{CHOICE CACTUS DAHLIAS}

Attraction. Very large attractive flowers, fully 6 inches in diameter, of a clear lilac rose, a rare color. 50 c each.

Carter Breck. Bright yellow at base, shading to rich carmine crimson. $25 \mathrm{c}$ each.

Electric. Clear canary yellow, each petal heavily tipped white. A lovely variety. 25c each.

George Walters. Beautiful large flowers of regular shape. Color a rich copper old gold, tinting to butt in center. $50 \mathrm{c}$ each.

Gladys Bates. Large perfect flowers, with incurved petals of a golden salmon, the reverse of the petals being rose. 50c each.

Golden West. A charming variety surpassing any of its class in flowering qualities. The color is pure golden yellow, shading to old gold. $35 \mathrm{c}$ each.

Mrs. Edna Spencer. Large flowers of a most delicate lavender pink color with white suffusion. One of the best for cutting. $50 \mathrm{c}$ each.

Sunset Glow. An attractive and beautiful Dahlia, color orange-red over chrome-yellow, the tips soft chrome-yellow. Its unique and pleasing color appeals to all. $50 \mathrm{c}$ each.

Washington City. Snow white, of beautiful form, the flowers are very large. 35 c each.

Collection-One each of the above Choice Cactus Dahlias for $\$ 2.75$, postpaid.

\section{PEONY-FLOWERED DAHLIAS}

Camille Fanchon. Color is an intense anilinerred, deepening to a rich garnet. 50c each.

Dr. Stem. The best of all red peony-flowered dahlias. Dístinct in every way. $75 \mathrm{c}$ each.

Fackel. Rich golden scarlet, tipped golden yellow. A lovely Autumn shade. 35c each.

Rosalia Styles. Rose pink flushed white, with lighter colored center. The largest and best pink of its class, beautiful form, stiff stems, a free and continuous bloomer. A superb cut flower variety. 50c each.

Collection. One each of the above, \$1.75.
Alaska. Pure white, the flowers are of good size and held erect on wiry stems. 25 c each.

Bob Pleuse. Rich purple, tipped white. Very early and a profuse bloomer. $50 \mathrm{c}$ each.

Bonnie Brea. Cream-shaded blush-pink. Very large, free bloomer. 50c each.

Challenge. Flowers large, yellow at the base, shading to bronzy red, tipped rích oriental red. $35 c$ each.

Laura Mary. Deep rose-pink, profuse bloomer on long stiff stems. 35c each.

La Grand Manitou. Immense size, lilac penciled crímson. 50c each.

Mary Swain. Color varies from flushed pink at center to rich maroon at tips. 35 c each.

Mina Burgle. Flowers of gígantic size and remark. able beauty, color a glowing brilliant scarlet. A variety of wonderful brilliance and attracts universal attention. $35 c$ each.

Mrs. I. De Ver Warner. An exquisite shade of mauve-pink. Its charming color, large blooms, and the very long, strong, wiry stems of this variety attracts attention wherever grown. $50 \mathrm{c}$ each.

Patrick O'Mara. The color is a pleasing shade of orange-buff, slightly tinged with beautiful deep rose color. Very large and one of the best of the Autumn shades. 50c each.

Porthos. A beautiful lavender blue flower of medium size, produced on long perfect stems. The nearest in troduction to a "blue" Dahlia. 50c each.

Venus. Color a pale lilac. Large and well-formed flowers and produced freely on long stems. 35c each.

Collection. We offer your selection any six of the above Decorative Dahlias at $1 / 5$ or $20 \%$ off the list price. 


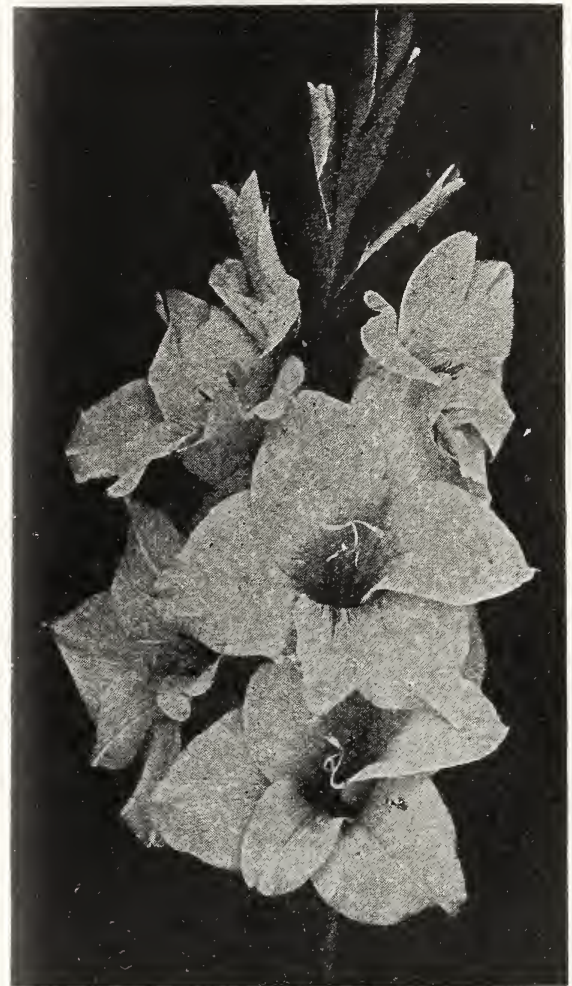

Niagara

\section{GLADIOLUS}

Gladioli are the most popular of all the Summer blooming bulbs, and are of the easiest culture. Elegant for the garden and cut-flower purposes, with a wide range of colors. In cutting for the house, it is best to cut the spike when the first flower opens, the balance of buds will develop when placed in water and thus prolong the blooming period. Bulbs should be planted 4 inches deep and at least 6 inches apart. Planting should be made every two weeks to provide for a succession.

America. Very light pink, exquisitely tinted with lavender. A magnificent variety. Each, 7c.; doz., 75c.; per 100, $\$ 4.50$.

Crimson Glow. Well named, the color being a glowing crimson scarlet. Each, 12c; doz., $\$ 1.25$; per 100 , $\$ 8.50$.

Evelyn Kirkland. Rosy pink, scarlet blotches on lower petals. Each, 12c.; per doz., \$1.25; per $100, \$ 8.50$.

Halley. Lovely salmon pink, very early. Each, $7 \mathrm{c}$; ; doz., 75c.; per 100, $\$ 4.50$.

Herada. The large blooms are dark lavender or rauve, with deep markings in throat. Each, 10 c.; doz., $\$ 1.00$; per $100, \$ 6.00$.

Lily White. Creamy white shading to white in center. A good cut flower. Each, 7c.; doz., $75 \mathrm{c}$; p per $100, \$ 4.50$.

Mrs. Francis King. Immense flowers of a most beautiful flame pink or light scarlet. The leading decorative gladioli. Each, 7c.; doz., 75c.; per $100, \$ 4.50$.

Mrs. Dr. Norton. Soft white, petals $\mathrm{La}$ France pink. Each, 12c.; doz., $\$ 1.25$; per $100, \$ 8.50$

Mrs. Frank Pendleton. Lovely salmon pink with rich maroon blotch on lower petals. Each, 10c.; doz., \$1.00; per 100, \$7.00.

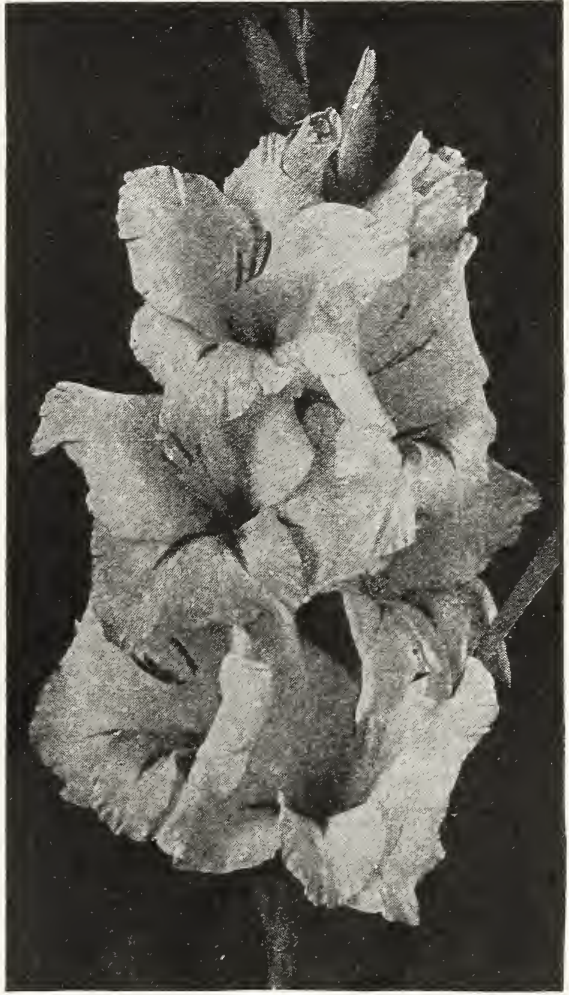

Panama

Niagara. Delicate cream-yellow, marked and splashed with rosy carmine in the throat. Each, 10c.; doz., $\$ 1.00$; per 100, $\$ 7.00$.

Panama. A rich rose pink flower, very large. Each, 10c.; doz., \$1.00; per 100, \$5.50.

Peace. Grand large flower, white with a trace of lilac on lower petals. Each, 10c.; doz., \$1.00; per $100, \$ 6.50$.

Pride of Goshen. A giant salmon or flesh pink. Each, 12c.; doz., \$1.25; per 100, $\$ 8.00$.

Rose Ash. A smoky old-rose color. Very distinct and outstanding. 12c. each; doz., \$1.25; per $100, \$ 8.50$.

Schwaben. Light orange yellow with deep red blotch. Each, 10c.; doz., \$1.00; per 100, $\$ 6.50$.

War. Deep blood red, shaded darkest crimson. Each, 12c.; doz., \$1.25; per 100, \$7.50.

Wilbrink. Flesh pink, with creamy white blotch on lower petals. A favorite variety for cutting. Each, 10c.; doz., 90c.; per 100, \$6.00.

Yellow Hammer. Pure yellow, red mark in throat. Each, 12c.; doz., \$1.25; per 100, \$7.00.

Special Offer. Two each of the following six varieties postpaid for 75c.: America, Mrs. Francis King, Peace, Yellow Hammer, Herada and Crimson Glow.

BUIST'S RAINBOW MIXTURE. Embraces a wide range of the different shades, blends and colors, carefully selected and mixed in proper proportion of color to please the most critical. 3 for 20c.; per doz., 75c.; per 100, \$5.00.

BUIST'S FINE MIXTURE. A popular lowpriced mixture composed of all colors and shades. 3 for 15 c.; 50c. per doz.; $\$ 3.00$ per 100 .

Single and dozen prices include postage. The 100 rate is by Express at purchaser's expense. 


\section{MADEIRA OR MEXICAN VINE}

A beautiful and popular vine covering a large space in a short time, much prized for porches and arbors because of its rapid growth and freedom from insects. Thick, glossy leaves of a light green color and numerous racemes of feathery white flowers of delightful fragrance. Take up and store in cellar over winter.

Large selected roots, $10 \mathrm{c}$ each, 3 for $25 \mathrm{c}$.; 85c. per doz., postpaid. By express, $\$ 5.00$ per 100 .

\section{TUBEROSES}

Excelsior White Pearl. The Tuberose is one of our finest Summerflowering bulbs. The flowers are waxy-white, double and exceed. ingly fragrant. A single flower will perfume a room. They do best in a rich warm soil and a sunny situation. Plant about the 1st of May in the open ground, but the bulbs may be started in pots much earlier.

Mammoth Bulbs. Price, 8c. each; per doz., 80c., postpaid. By express or freight, 70c. per doz.; $\$ 5.00$ per 100 .

Large Size Bulbs. Price, 6c. each; per doz., 60c., postpaid. By express or freight, 50c. per doz.; $\$ 3.50$ per 100 .

We do not handle second size bulbs because of the uncertainty of their blooming.

\section{HARDY JAPAN LILIES}

No garden can be complete without a fair display of these stately flowers. Their graceful habits, their ability to adapt themselves to special locations, blooming almost the entire summer, make them very valuable. Their culture is simple, yet a few rules must be strictly observed to grow them successfully.

All Lilies should be planted from 6 to 8 inches deep, the Japanese varieties even 12 inches deep, the bulbs themselves should be completely enveloped in sand; no manure should come in contact with the bulb, but may be placed 4 to 6 inches underneath, all loosepetaled bulbs should be planted on their side instead of upright.

Lilium Auratum (Golden-banded Lily from Japan). A variety planted most extensively; flowers of enormous size, measuring frequently 8 to 10 inches across; pure white, spotted crimson; each petal is marked in the center with a band of yellow. Flowers in August, delightfully fragrant; a single stem produces on an average from eight to twelve flowers.

Each

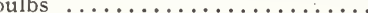

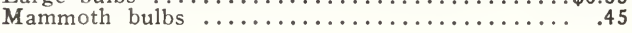

Doz.

$\$ 3.50$
4.50

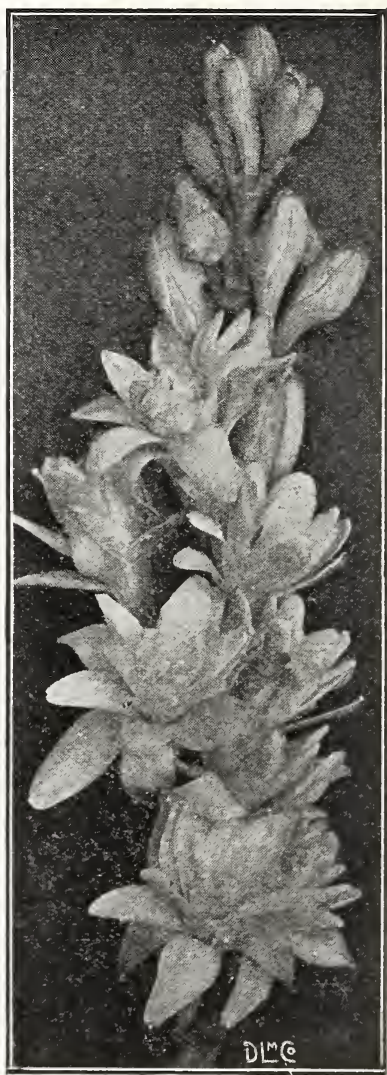

Tuberose

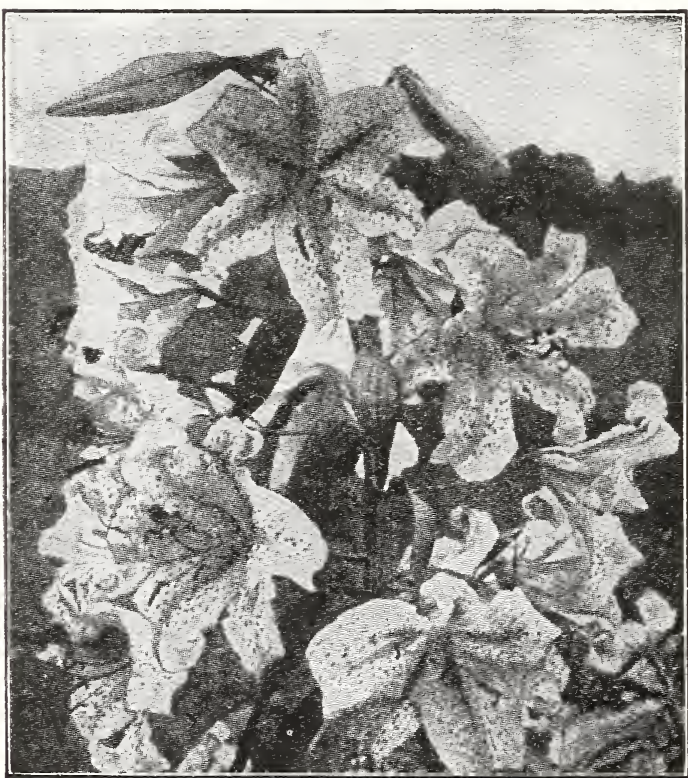

Lilium Auratum, "The Queen of Lilies"
Speciosum Album. The best-flowering, pure white hardy garden Lily of easy culture. Height, 4 feet; blooms August and September. Each Doz. Large bulbs .......\$0.50 \$5.00 Mammoth bulbs ........ $60 \quad 6.50$ Speciosum Rubrum or Roseum. Delicate pink, almost white. spotted red"; one of the old garden favorites. Flowers in August and September. $\quad$ Each Doz. Large bulbs .......\$0.40 \$3.50 Iammoth buibs ........ $50.50 \quad 5.00$ Tigrinum (Tiger Lily), Orange, spotted black; 2 to 5 feet; blooms in August. Each, 25c.; doz., \$2.25.

\section{REGALE LILY}

A beautiful new variety from Western China. It grows 3 to 5 ft. high, and blooms out of doors in July. The flowers are white, shading to yellow in the center, with a pink tinge on the outer edge. It is perfectly hardy and deliciously scented. 60c. each, $\$ 6.00$ per doz.

Bulbs mailed free at single and dozen prices. Rates on larger quantities do not include postage. 


\section{INSECT DESTROYERS}

\section{Insecticides contain poison and cannot be sent by mail}

ANSECTO ROSE BUG DESTROYER. Highly effective when used on rose bugs, red spider, mealy bug and other garden pests. 4 ozs., 30c.; pint, $\$ 1.00$.

ANT KILLER. Very effective for the destruction of ants on lawns, golf courses, etc. $4 \frac{1}{2}$ oz. cans, $50 \mathrm{c}$.

ARSENATE OF LEAD (Powder). Produced under a new process containing a greater percentage of Arsenic Oxide than required by the U. S. laws. It mixes easier and sticks better than any other brand. Dilute 1 to 50 . $1 /$ lb., 20c.; 1 lb., 35c.: 5 lbs., $\$ 1.75 ; 10$ lbs., $\$ 3.00 ; 25$ lbs., $\$ 7.00 ; 100$ lbs., $\$ 25.00$.

BORDO-LEAD (Pestroy) (Powdered). A combination of arsenate of lead and Bordeaux mixture. It sticks to the foliage. $1 / 2 \mathrm{lb}, 25 \mathrm{c}$. ; 1 lb., 45c.; 5 lbs., $\$ 2.00$; 10 lbs., $\$ 3.50$.

BORDEAUX MIXTURE (Powder). Can be used dry or as a spray; when used as a spray dilute 1 to 8. lbs., $\$ 2.50$.

CALCIUM ARSENATE. For spraying and dusting potatoes. $1 / 2 \mathrm{lb},{ }^{2} \mathrm{c}$.; $1 \mathrm{~b}$., $35 \mathrm{c}$.

COATED ARSENATE LEAD (Japanese Beetle Spray). Will protect foliage with one spraying and is recommended by the Japanese Beetle Laboratory. 5 pounds will make 50 gallons of spray. 1-1b. jar, 60c.; 21/2-1b. jar, $\$ 1.00$.

CUT WORM FOOD. A sweetened poisoned compound, alluring and palatable to cut worms, cabbage worms, etc. 1 pound for 100 plants. 1 lb., 45c.; 5 lbs., $\$ 1.75$.

EVERGREEN INSECTICIDE. Effective against cutworms, cucumber beetles, cabbage worms, rose slugs, aphis, etc. Non-poisonous. Oz., 35 c. ; 6 ozs., $\$ 1.00 ; 1$ lb., $\$ 2.00 ; 2$ lbs., $\$ 3.50$.

HELLEBORE. For destroying rose slugs, currant and cabbage worms, $1 / 2$ lb., 30c.; $1 \mathrm{lb}$., 50c.; 5 lbs., \$2.25.

LEMON OIL. For destroying scale, caterpillar, mealy bug, etc. Dilute with 10 parts water. I/2 pt., 35c.; pt., 60c.; qt., $\$ 1.00$.

LIME AND SULPHUR SOLUTION. A perfect remedy for San Jose scale and all other fungus diseases. One gallon makes ten. When used in summer dilute 1 to 30.1 qt., $45 \mathrm{c}$.; $1 / 2$ gal., 70c.; 1 gal., $\$ 1.10 ; 5$ gals., $\$ 3.50$.
LIME SULPHUR (Dry). A very effective remedy for San Jose scale and other fungus diseases. Has all the effectiveness of liquid lime sulphur and is much easier to handle. 1 pound to 5 gallons of water. $1 \mathrm{lb}, 35 \mathrm{c}$.; 5 lbs., $\$ 1.40$; 10 lbs., \$2.25; 25 lbs., \$4.50; 50 lbs., $\$ 8.00 ; 100$ lbs., $\$ 15.00$.

PARIS GREEN. For destroying potato bugs. Effective against all chewing insects. Directions for use with each package. $1 / 4$ lb., 15c.; $1 / 2$ lb., 25c.; 1 lb., 45c.; 2 lbs., 80c.; 5 lbs., $\$ 1.75$.

P. T. B. (Para Dichlorobenzine). For peach tree borers, full directions on package. Use only in August and September. 1 lb., 65c.; 5 lbs., $\$ 2.50 ; 10$ lbs., $\$ 4.50$.

PYROX. The best and safest all-around spray for all leaf-eating insects, blight and fungus troubles. Mixes easily in cold water; dilute $1 \mathrm{lb}$. to 5 gals. water. Kills potato bugs. Sticks like paint. 1 lb., 50c.; 5 lbs., \$1.75; 10 lbs., $\$ 3.00 ; 25$ lbs., $\$ 6.25 ; 50$ lbs., $\$ 10.75$; 100 lbs., \$15.50.

SLUG SHOT. A non-poisonous powder insecticide; it requires no mixing or preparation, casily applied and not injurious to animals, the person applying it, or fruits and vegetables treated. Very effectual in destroying potato bugs and the Mexican bean beetle, green flies, slugs, worms, etc. $1 \mathrm{lb}$., canister, $20 \mathrm{c}$. 5 lbs., 55c.; 10 lbs., $\$ 1.00$.

SULPHUR POWDER. For mildew. Lb., 10c. 5 lbs., 45c.; 10 lbs., 80c.; 50 lbs., $\$ 3.50 ; 100$ lbs., $\$ 6.50$.

TREE TANGLEFOOT. A sticky compound for painting around the trunks of trees to protect them from all creeping insects, Lb., 50c.; 5 lbs., $\$ 2.40 ; 10$ lbs., \$4.50.

TOBACCO DUST. For dusting only. Excellent for Lettuce and other plants to destroy soft creeping insects. Lb., 10c.; 5 lbs.. 35c.; 10 1bs., 60c.; 25 lbs., $\$ 1.25 ; 100$ lbs., $\$ 3.50$.

WEED KILLER. The method of killing weeds thoroughly by application of this liquid has become general. It is a great labor-saver. It is to be used only on patls, drives, gutters and places where no growth is wanted. One gallon will make 50 gallons of treating liquid, sufficient to cover 150 square yds. 1 qt., 50c.; $1 / 2$ gal.. 80c.; 1 gal., $\$ 1.50 ; 5$ gals. $\$ 6.00 ; 30$ gals., $\$ 28.00 ; 50$ gals., $\$ 45.00$.

\section{"BLACK LEAF 40"}

\section{Nicotine Sulphate- $-40 \%$ Nicotine}

"Black Leaf 40 " is a concentration of Nicotine Sulphate and is guaranteed to contain not less than $40 \%$ of nicotine by weight. It destroys aphis (plant lice), thrip, leaf hoppers and similar insect pests in the truck garden, orchard, flower garden, vineyard, etc. It has been highly recommended by Experiment Stations throughout the United States as a spray for soft-bodied sucking insects. II May be combined with other sprays. Soluble in cold water. Does not clog the nozzle.

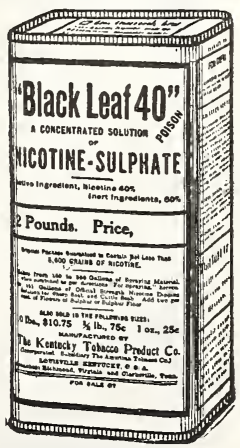

\section{You Cannot Go Wrong by Ordering "Black Leaf 40" for Sucking Insects}

1 ounce bottle, $35 \mathrm{c}$., makes 5 to 10 gallons; $1 / 21 \mathrm{~b}$. can, $\$ 1.25$, makes 40 to 100 galions; 2 lb. can, $\$ 3.25$, makes 200 to 500 gallons; $10 \mathrm{lb}$. can, $\$ 11.85$. 


\section{FERTILIZERS}

BUIST'S LAWN ENRICHER. As a fertilizer or dressing for inducing a rapid and luxuriant growth of grass it cannot be excelled. It is dependable as it contains all the essential elements grass requires. Lawns should be topdressed twice a year, once before the new Spring growth cominences and again in the Fall before active growth stops, this will induce a deep, thick root growth which will enable the lawn to withstand the hot, dry months. Broad cast at the rate of 600 pounds per acre. $5 \mathrm{lbs}$., 35c.; 10 lbs., 60c.; 25 lbs., $\$ 1.10$; 50 lbs., $\$ 2.00$; 100 lbs., $\$ 3.50$; sack of 200 lbs., $\$ 6.00$; ton, $\$ 50.00$.

COW OR CATTLE MANURE (Shredded). An effective high-grade natural fertilizer for garden, lawn and greenhouse: especially good to mix with compost. It makes a rich and safe liquid manure. 5 lbs., 35c.; 10 lbs., 60c. 25 lbs., $\$ 1.25 ; 100$ lbs., $\$ 3.50$; 500 lbs., $\$ 16.00$; 1000 lbs., $\$ 30.00$; ton, $\$ 58.00$.

BUIST'S PURE BONE MEAL. Excellent for top-dressing lawns, the beneficial results can be noted for a long time. A very desirable fertilizer for roses, flowering shrubs, fruit bushes and trees. Apply 800 to 1000 lbs. per acre, 25 lbs. for every 1000 square feet. 5 lbs., $35 \mathrm{c}$; 10 lbs., 60c.; 25 lbs., $\$ 1.25 ; 50$ lbs., $\$ 2.25$; 100 lbs., $\$ 4.00 ; 200-1 b$. sack, $\$ 7.00$; ton, $\$ 60.00$.

CANADA U N L EA C H E D HARDWOOD ASHES. Indispensable as a lawn dressing or for orchards. They should be applied late in Fall or early in Spring, so that the rains and snows may leach the ashes and carry the nourishment down to the roots of grass or trees. Apply 2000 pounds per acre. 5 lbs., 25c.; 10 lbs., 40c.; 25 lbs., 80c.; 100 lbs., $\$ 2.50$; 200 lbs., $\$ 4.00$; ton, $\$ 35.00$.

FLORANID (Urea). A quick-acting stimulant for lawns, vegetables, fruits and flowers, contains 46 per cent available nitrogen. Lb. cans, 50c.; 5 lbs., $\$ 2.00 ; 10$ lbs., $\$ 3.00$.
NITRATE OF SODA. A valuable fertilizer. Apply 100 to $150 \mathrm{lbs}$. per acre, but not until the plants are above ground. If used in liquid form, dilute two ounces to one gallon of water and apply twice a week. 1 lb., 15c.; 2 lbs., 25c.; 5 lbs., 40c.; 10 lbs., 70c.; 25 lbs., \$1.50; 50 lbs., $\$ 2.50 ; 100$ lbs., $\$ 4.50 ; 200$ lbs., \$8.50.

LIME (Hydrated or Powdered). Makes sour soil sweet and heavy soil light. Promotes growth and gives the lawn a rich color. 10 lbs. to 200 square feet, or 1 ton to acre. $10 \mathrm{lbs}$., 30c.; 50 lbs., 90c.; 100 lbs., $\$ 1.65$; 500 lbs., $\$ 7.50$; ton, $\$ 25.00$.

NITROPHOSKA. A highly concentrated quickacting fertilizer. $15 \%$ potash, $30 \%$ phosphoric acid, $15 \%$ nitrogen. Lb., 35c.; 5 lbs., \$2.00; 10 lbs., $\$ 3.00$.

MURIATE OF POTASH. Should be used on all root crops. Potatoes, beets, turnips require a liberal proportion of potash in order to develop properly. 5 lbs., 35c.; 10 lbs., 60c.; 25 lbs., $\$ 1.25$; 50 lbs., $\$ 2.00$; 100 lbs., $\$ 3.50 ; 200$ lbs., $\$ 6.50$; ton, $\$ 55.00$.

PHOSPHATE (16\% Acid Phosphate). For all vegetable crops, grains, etc. Apply 800 lbs. per acre. 5 lbs., 20c.; 10 lbs., 35c.; 25 lbs., 75 c.; 50 lbs., $\$ 1.25 ; 100$ lbs., $\$ 2.00 ; 200$ lbs., $\$ 3.25$.

POTATO AND TRUCK SPECIAL. Adapted for use on all truck crops. It is of exceptional value and will prove a money maker to all gardeners. 5 lbs., 30c.; 10 lbs., 50c.; 25 lbs., $\$ 1.00 ; 100$ lbs., $\$ 3.00 ; 200$ lbs., $\$ 5.00$; ton, $\$ 45.00$.

SULPHATE OF AMMONIA. A nitrogenous plant-stimulant, very quick in action. Used on lawns as a stimulant and to discourage weed growth. $1 \mathrm{lb}$, to $150 \mathrm{sq}$. ft., or $300 \mathrm{lbs}$. per acre. 5 lbs., 60c.; 10 lbs., \$1.10; 25 lbs., $\$ 1.75 ; 100$ lbs., $\$ 5.00$.

STIM-U-PLANT. A highly concentrated plant food in tablet form. Can be used on all flower, vegetable, fruit and ornamental plants. Per pkg. of 30 tablets, 25c.; 100 tablets, 75c.; 1000 tablets, $\$ 3.50$.

\section{VIGORO}

\section{For Lawns, Gardens, Flowers, Shrubbery, Trees}

\section{For Gardening Success}

Scientifically balanced and complete, VIGORO is a specially prepared plantfood. It contains all of the elements necessary to grow richly colored flowers, velvety lawns, succulent vegetables, luxuriant shrubbery and healthy trees.

VIGORO is odorless and clean. It can be applied by hand just like grass seed. Complete directions for applying VIGORO for all plants are contained in every bag. VIGORO should be used at the rate of four pounds per 100 square feet $(10 \mathrm{ft}$. $\times 10 \mathrm{ft}$.) in the Spring and Fall. Use one-half this amount for Summer feeding.

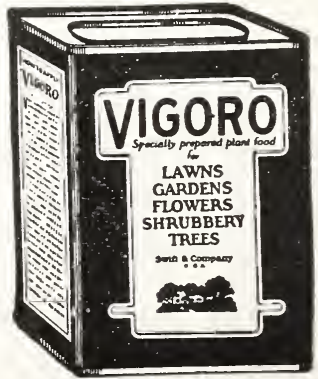




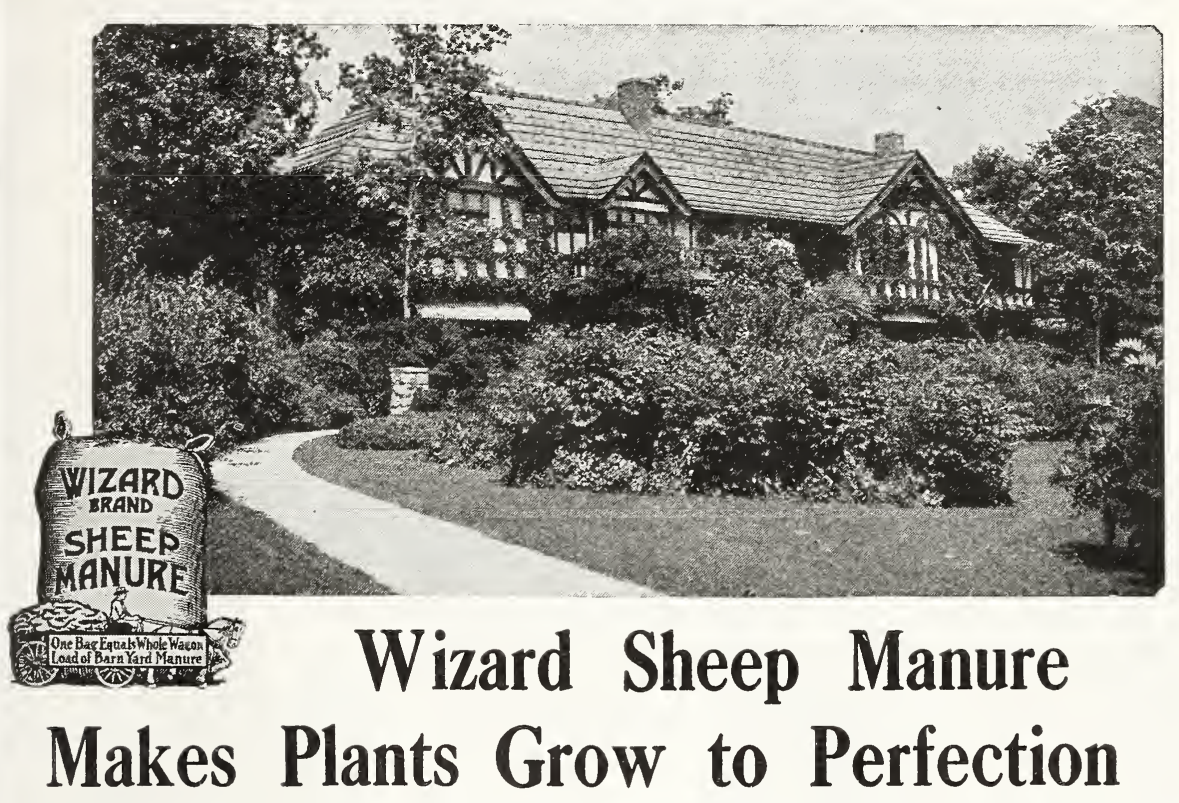

Wizard is a concentrated weedless manure that puts new life and beauty into lawns and gardens. Everybody can get wonderful results with this natural fertilizer because it is easy to use and does not burn plants. You can make your lawn and garden the envy of the neighborhood if you will feed your plants with Wizard Sheep Manure.

FOR LAWNS. Wizard produces thick, velvety, green lawns of lasting beauty. It supplies the humus and natural plant food so necessary to feed the millions of grass plants that make up a thick, green turf. On new lawns apply 10 lbs. to $100 \mathrm{sq}$. ft. and rake into the surface soil. On old lawns rake thorough$1 \mathrm{y}$ and then broadcast 6 to 10 1bs. per 100 sq. ft. Scatter Wizard just as you would sow seed.

FLOWER GARDENS-SHRUBBERY. Wizard promotes luxuriant green foliage and a wealth of vivid colored flowers. It is the safest and best plant food for flowers, shrubbery, vines and trees. Mix a handful with the soil under each new plant and on established plants 10 lbs. to $100 \mathrm{sq}$. ft. raked into the surface soil. Use more for shrubs, vines and trees. Liquid manure used once a week will prolong the blooming season.

VEGETABLES AND FRUITS. Every practical gardener knows that there is nothing better than manure to build up the soil and produce big profitable crops. Wizard is the best manure in a highly concentrated form. It produces big crops of crisp, tender vegetables in time for the early market. A practical fertilizer for every grower. Use 1000 to 1500 lbs, per acre.

FLORISTS. Wizard has been the old reliable fertilizer for the under glass grower for over twenty-one years. It is safe and dependable for all crops grown under glass.

\section{PRICES}

5 pounds $\ldots \ldots \ldots \ldots \ldots . \$ 0.40$

10 pounds $\ldots \ldots \ldots \ldots \ldots . .65$

25 pounds .................... 1.25

50 pounds .............. 2.00
100 pounds ..........\$ 3.50

500 pounds ........... 16.00

1000 pounds .............. 30.00

2000 pounds ........... 58.00

\section{WIZARD Sheep Manure}




\section{INDEX TO GONTENTS}

\section{VEGETABLE SEEDS}

\section{Artichoke ............... 14}

Asparagus .............. 14

Beans, Bush, Green Podded 15, 16

Beans, Bush. Wax Podded 17. 18

Beans, Dwarf Lima

Beans, Pole Lima ......... 21

Beans, Pole and Cornfield 19, 20

Beets, Garden ...........22, 23

Beets, Swiss Chard ......... 2

Beets, Mangels ..............24, 25

Broceli

Brussels sprouts ........... 25

Cabbage $\quad \ldots \ldots \ldots \ldots \ldots 26$ to 30

Cauliflower ...............33

Celery $\ldots \ldots \ldots \ldots \ldots \ldots \ldots \ldots 34,35$

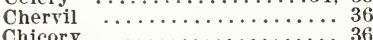

Chicory $\ldots \ldots \ldots \ldots \ldots \ldots \ldots \ldots \ldots$
Chives $\ldots \ldots \ldots \ldots \ldots \ldots \ldots \ldots$

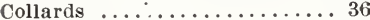

Corn, Sweet .........36 to 38

Corn, Field .................. 40

Corn, Pop $\ldots \ldots \ldots \ldots \ldots \ldots \ldots \ldots .40 \ldots \ldots \ldots$

Corn Salad ................. 4

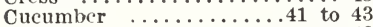

Dandelion $\ldots \ldots \ldots \ldots \ldots \ldots \ldots \ldots 43$

Egg Plant $\ldots \ldots \ldots \ldots \ldots \ldots .44$

Enatve $\quad \ldots \ldots \ldots \ldots \ldots \ldots \ldots \ldots \ldots \ldots \ldots \ldots \ldots$
Fennel $\ldots \ldots \ldots \ldots \ldots \ldots$

Herbs

Kale $\ldots \ldots \ldots \ldots \ldots \ldots \ldots \ldots \ldots 44$

Kohl Rabi ................ 46

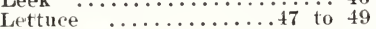

Melon, Musk .......50 to 53

Melon, Water ..........

Mushroom Spawn .......... 57

Mustard ................ 57

Onion Seeds ...................... to 62

Onion Sets $\ldots \ldots \ldots \ldots \ldots . \ldots 62$

Parsnip

Peas, Garden ...........64 to 68

Peas, Field ............ 96

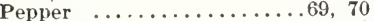

Potatoes $\ldots \ldots \ldots \ldots \ldots \ldots \ldots .71,72$

Pumpkins $\ldots \ldots \ldots \ldots \ldots \ldots \ldots \ldots \ldots .74$ to 79

Rhubarb ............. 77

Salsify $\ldots \ldots \ldots \ldots \ldots \ldots \ldots \ldots \ldots \ldots \ldots 77$

Sorrel

Spinach

Squash

Swiss Chard ................ 79

Tobacco ............... 90

Tomato $\ldots \ldots \ldots \ldots \ldots . .61$ to 85

Turnip

86 to 90

Grass and Clover Seeds

Clover Seeds

Grass Seeds

Lawn Grass

$.93,94$

Pasture Grass

$.91,92$

FARM SEEDS, Etc.

Barley

Broom Corn

Buckwheat

Cow Peas

Fertilizer

Insecticides

Kaffir Corn

Millets

Oats

Rape, Essex

Rye

Soja Beans

Sugar Cane

Sunflower

Teosinte

Vetch

\section{BULBS and ROOTS}

Amaryllis $\ldots \ldots \ldots \ldots \ldots \ldots 128$ Begonias . . . . . . . . . . 128

Caladium (Elephant's Ears) 128

Cinnamon Vine .......................

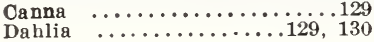

Gladiolus

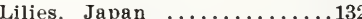

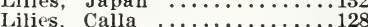

Madeira or Mexican vine ...132

Tuberoses ...............132

\section{FLOWER SEEDS}

Abutilon ............. 99

Achillen

Aconitum

Acroclinium

Ageratum

Alyssum $\ldots \ldots \ldots \ldots \ldots \ldots \ldots \ldots .999$

Amaranthus $\ldots \ldots \ldots \ldots \ldots \ldots 100 \ldots \ldots$

Ampelopsis $\ldots \ldots \ldots \ldots \ldots \ldots .99$

Anchusa ...............100

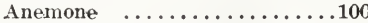

Antirrhinum $\ldots \ldots \ldots \ldots \ldots \ldots \ldots$

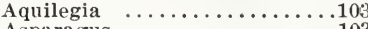

Asparagus $\quad \ldots \ldots \ldots \ldots \ldots \ldots . \ldots 10 . \ldots \ldots$

Asters $\ldots . \ldots \ldots \ldots . . . .101$ to 102

Aurieula ...................

Baby's Breath ..................111

Bachelor's Button ........106

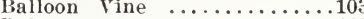

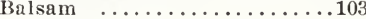

Balsam Apple and Pear .....115

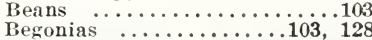

Bellis Perennis ............104

Black-Eyed Susan ...........125

Blue Lace Flower ..........109

Boston Ivy ............ 99

Brachycome $\ldots \ldots \ldots \ldots \ldots \ldots 104$

Browallia ...........................

Bitterfly Flower ..........121

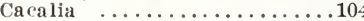

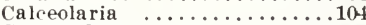

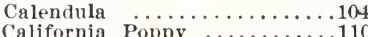

California Poppy ...........110

Calliopsis $\ldots \ldots \ldots \ldots \ldots \ldots .104$

Canary Bird vine ................

Canary Bird

Canterbury Bells ................

Canna ...............105, 129

Carnations ............. 10 .

Cardinal Climber ............108

Castor Oil Plant .............120

Celosia ...............105 to 106

Centaureas ....................

Chinese Forget-Me-Not ......108

Chiuese Lantern Plant ......107

Chinese Woolflower ............106

Chinese Primrose ............120

Chrysanthemum $\ldots \ldots \ldots \ldots \ldots 107$

Cineraria $\ldots \ldots \ldots \ldots \ldots \ldots \ldots . \ldots 107$

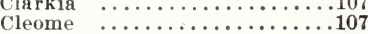

Cobea $\ldots \ldots \ldots \ldots \ldots \ldots \ldots \ldots . \ldots \ldots 107$

Cockscomb ....................

Coleus $\ldots \ldots \ldots \ldots \ldots \ldots \ldots \ldots \ldots . . . \cdots \ldots$

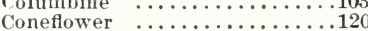

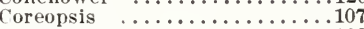

Cosmos $\ldots \ldots \ldots \ldots \ldots \ldots \ldots . \ldots 10 \%$

Cowslip ...............120

Cyclamen .............108

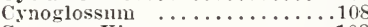

Cypress Vine ...................

Dahlias $\ldots \ldots \ldots \ldots$.

Delphinium ........................

Dianthus

Didiscus $\quad \ldots \ldots \ldots \ldots \ldots \ldots \ldots \ldots \ldots \ldots$

Digitalis $\ldots \ldots \ldots \ldots \ldots \ldots \ldots \ldots$

Dimorphotheca $\ldots \ldots \ldots \ldots \ldots 11$

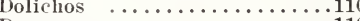

Dracaena $\ldots \ldots \ldots \ldots \ldots \ldots \ldots$

Dusty Miller .............. 106, 107

Eschscholtzia $\quad . \ldots \ldots \ldots \ldots . .110$

Euphorbia ............

Forget-Me-Not

Four o'Clock ...........................

Four o'Clock $\ldots \ldots \ldots \ldots \ldots \ldots \ldots 115$
Foxglove $\ldots \ldots \ldots \ldots \ldots \ldots \ldots \ldots$

Gaillardia $\ldots \ldots \ldots \ldots \ldots \ldots \ldots . \ldots \ldots 11$

Geranium .................111

Geum $\ldots \ldots \ldots \ldots \ldots \ldots . \ldots \ldots$

Gilia $\ldots \ldots \ldots \ldots \ldots \ldots \ldots \ldots \ldots \ldots \ldots \ldots \ldots \ldots \ldots \ldots \ldots \ldots 111$

Globe Amaranth ...........11

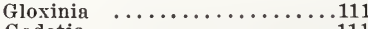

Godetia $\ldots \ldots \ldots \ldots \ldots \ldots \ldots . \ldots \ldots$

Golden Feather ............12

Gourd, Ornamental ...........111
Page

Helianthemum $\ldots \ldots \ldots \ldots \ldots$.................

Helianthus $\ldots \ldots \ldots \ldots \ldots \ldots \ldots 112$

Helichrysum $\quad \ldots \ldots \ldots \ldots \ldots \ldots \ldots 112$

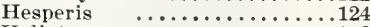

Heliotrope $\quad \ldots \ldots \ldots \ldots \ldots \ldots . \ldots 112$

Hibiscus $\ldots \ldots \ldots \ldots \ldots \ldots \ldots 112$

Hollyhock $\quad \ldots \ldots \ldots \ldots \ldots \ldots \ldots 112$

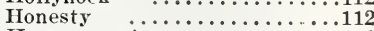

Hunnemannia $\quad \ldots \ldots \ldots \ldots \ldots \ldots 112$

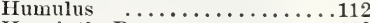

Hyacinth Bears .........110

Iberis $\ldots \ldots \ldots \ldots \ldots \ldots \ldots \ldots \ldots \ldots 112$

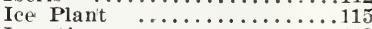

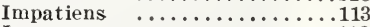

Ipomoea $\ldots \ldots \ldots \ldots \ldots \ldots \ldots . \ldots . \ldots . \ldots \ldots$

Kenilworth Iry ....................

Kochia $\quad \ldots \ldots \ldots \ldots \ldots \ldots \ldots \ldots 113$

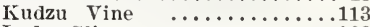

Lady Slipper $\ldots \ldots \ldots \ldots \ldots . \ldots 10 . \ldots$

Lantana $\ldots \ldots \ldots \ldots \ldots \ldots \ldots . \ldots \ldots$

Larkspur $\quad \ldots \ldots \ldots \ldots \ldots \ldots 109,113$

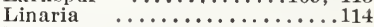

Linum $\quad \ldots \ldots \ldots \ldots \ldots \ldots \ldots 114$

Lobelia $\quad \ldots \ldots \ldots \ldots \ldots \ldots \ldots \ldots 11$

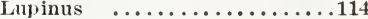

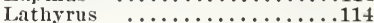

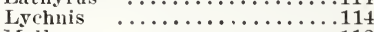

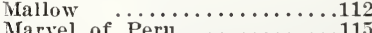

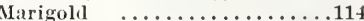

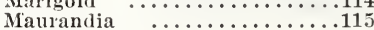

Mesembryanthemiun $\ldots \ldots \ldots \ldots 115$

Mignonette $\quad \ldots \ldots \ldots \ldots \ldots \ldots . . .11$

Mimosa $\quad . \ldots \ldots \ldots \ldots \ldots \ldots . . .115$

Mimulus $\ldots \ldots \ldots \ldots \ldots \ldots \ldots . \ldots \ldots \ldots . \ldots \ldots$

Memordica $\quad \ldots \ldots \ldots \ldots \ldots \ldots \ldots \ldots$.

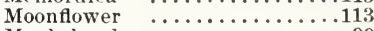

Monkshood .............. 99

Morning Glory ...........113

Mourning Bride ...........121

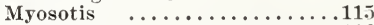

Nasturtiums $\quad \ldots \ldots \ldots \ldots \ldots \ldots 116$

Nicotiana $\quad \ldots \ldots \ldots \ldots \ldots \ldots \ldots$.

Nigella $\quad \ldots \ldots \ldots \ldots \ldots \ldots \ldots \ldots$.

Oenothera $\quad \ldots \ldots \ldots \ldots \ldots \ldots \ldots \ldots \ldots \ldots \ldots \ldots \ldots \ldots \ldots \ldots$
Pansies

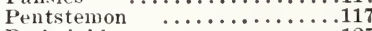

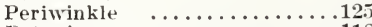

Petunia $\quad \ldots \ldots \ldots \ldots \ldots \ldots \ldots . \ldots \ldots 118$

Phlox Drummondii ........118

Physalis $\ldots \ldots \ldots \ldots \ldots \ldots 107$

Pinks
Poples

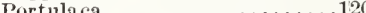

Primula

Primrose, Evening $\ldots \ldots \ldots \ldots 115$

Puelaria $\ldots \ldots \ldots \ldots \ldots \ldots \ldots 113$

Pyrethrum $\ldots \ldots \ldots \ldots \ldots \ldots . \ldots \ldots$

Ricinus

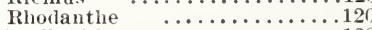

Rndbeckia $\ldots \ldots \ldots \ldots \ldots \ldots 120$

Salpiglossis $\quad \ldots \ldots \ldots \ldots \ldots \ldots 12$

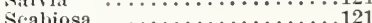

Scarlet Sage $\ldots \ldots \ldots \ldots \ldots \ldots 121$

Schizanthns $\quad \ldots \ldots \ldots \ldots \ldots \ldots 121$

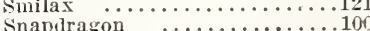

Snow on the ilountain ..................

Statice $\quad \ldots \ldots \ldots \ldots \ldots \ldots \ldots . \ldots 121$

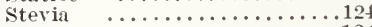

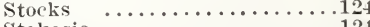

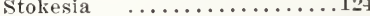

Sunflower $\ldots \ldots \ldots \ldots \ldots \ldots \ldots 11$

Sweet Peas ..........122. 123

Sweet Rocket .............124

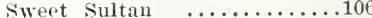

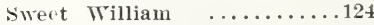

Tagetes $\ldots \ldots \ldots \ldots \ldots \ldots \ldots \ldots 114$

Thunbergia $\ldots \ldots \ldots \ldots \ldots \ldots . \ldots 12$.

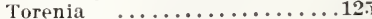

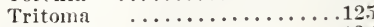

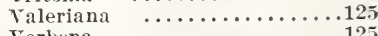

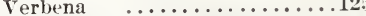

Veronica $\ldots \ldots \ldots \ldots \ldots \ldots \ldots$.

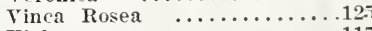

Violas $\quad \ldots \ldots \ldots \ldots \ldots \ldots \ldots . \ldots \ldots 117$

Violets $\quad \ldots \ldots \ldots \ldots \ldots \ldots \ldots \ldots 12$

Wallflower $\quad \ldots \ldots \ldots \ldots \ldots \ldots .125$

Wild Flower Garden $\ldots \ldots .125$
Youth and Old Age ...126, 127

Zinnia $\ldots \ldots \ldots \ldots \ldots \ldots 126,127$ 


\section{THIS IS THE 102nd YEAR FOR}

\section{Buist's Garden Seeds}

\section{Buist's Seeds are grown from the Finest Selected Stocks Those who sow them will not be disappointed}

\section{Suggestions to Customers in Ordering from this Catalogue, which, if followed, will be of mutual aid}

HOW TO ORDER.-Please write your name, post-office and state plainly; if your express or freight office is different from your post-office don't fail to mention it.

WE MAIL SEEDS POSTAGE PAID(except as noted). We deliver Free to any Express- or Post-Office in the United States all Flower and Vegetable Seeds quoted in this catalogue by the Packet, Ounce, Quarter-pound or Pound, except as follows: If Peas, Beans, Corn, Onion Sets Grass and Field Seeds or Fertilizers are wanted by Mail please add postage to cover cost of Parcel Post according to the Zone scale tabulated below. The average weight of $1 \mathrm{qt}$. of Onion Sets and Lawn Grass Seed is $1 \mathrm{lb}$. Express charges are, as a rule, cheaper than Parcel Post on large packages.

HOW TO SEND MONEY.-Send cash with order by express or registered mail, by draft on Philadelphia or New York, or by Postal Money-order. Postage stamps will be found a convenient method of remitting for small amounts.

NO CHARGE is made for boxes, packing or bags, except for 2-bushel seamless sacks at $45 \mathrm{c}$. each.
OUR SERVICE DEPARTMENT will take pleasure in advising any of our customers desiring assistance or advice in connection with the Garden or Farm.

WHOLESALE PRICES to Market Gardeners and all other large purchasers of Seeds.-If you purchase seeds largely or grow Vegetables for Market, send for our Market Gardeners' Quarterly, which gives our wholesale prices to which you are entitled.

NON-WARRANTY.-Seeds of the best quality will often fail through improper treatment. This may be due to one or more of several reasons, such as covering too deeply or not deeply enough, too much or too little water, too cold weather or a baking sun which forms a crust too hard for the tender shoots to penetrate. Sometimes insects destroy plants at the surface before they are seen by the gardener. We cannot personally direct the use of our goods after they leave our hands; neither can we fully control anywhereorat any time theoperation of natural law as it affects seeds; therefore we give no warranty, express or implied, as to description, purity, productiveness, or any other matter of any seeds or bulbs we send out, and we will not be in any way responsible for the crop. If the purchaser does not accept the goods on these terms they are at once to be returned.

Robert Buist Company
DOMESTIC PARCEL POST RATES

On Seeds, Plants, Bulbs, Roots, etc., within the U. S. or Possessions

\begin{tabular}{c|c}
$\begin{array}{c}\text { First } \\
\text { pound or } \\
\text { fraction }\end{array}$ & $\begin{array}{c}\text { Each } \\
\text { additional } \\
\text { pound or } \\
\text { fraction }\end{array}$ \\
\hline $7 \mathrm{c}$. & $1 \mathrm{c}$. \\
$7 \mathrm{c}$. & $1 \mathrm{c}$. \\
$8 \mathrm{c}$. & $2 \mathrm{c}$. \\
$8 \mathrm{c}$. & $4 \mathrm{c}$. \\
$9 \mathrm{c}$. & $6 \mathrm{c}$. \\
$10 \mathrm{c}$. & $8 \mathrm{c}$. \\
$12 \mathrm{c}$. & $10 \mathrm{c}$. \\
$13 \mathrm{c}$. & $12 \mathrm{c}$.
\end{tabular}

\section{ROBERT BUIST COMPANY Seed Merchants}

Seed Warehouse, Nos, 4 and 6 South Front Street, Philadelphia, Pa. 


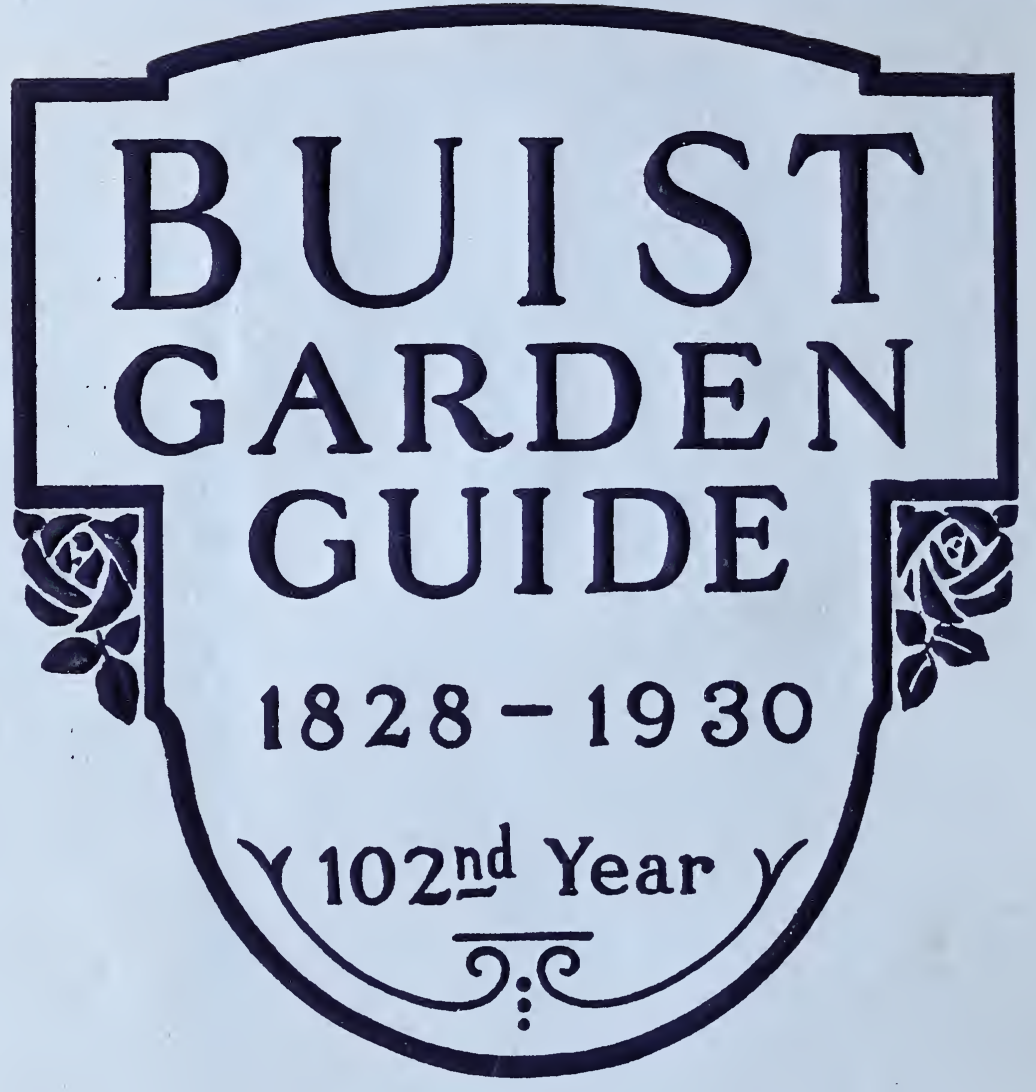

ROBERT BUIST COMPANY

Seed Growers

Philadelphia, PA. 